UNIVERSIDADE DE SÃO PAULO

FACULDADE DE FILOSOFIA, LETRAS E CIÊNCIAS HUMANAS

DEPARTAMENTO DE GEOGRAFIA

\title{
"Exculhidos": ex-moradores de rua como camponeses num assentamento do MST
}

Marcelo Gomes Justo

São Paulo 
UNIVERSIDADE DE SÃO PAULO

FACULDADE DE FILOSOFIA, LETRAS E CIÊNCIAS HUMANAS

DEPARTAMENTO DE GEOGRAFIA

\section{"Exculhidos": ex-moradores de rua como camponeses num assentamento do MST}

\section{Marcelo Gomes Justo}

Tese apresentada ao Programa de PósGraduação em Geografia Humana do Departamento de Geografia da Faculdade de Filosofia, Letras e Ciências Humanas da Universidade de São Paulo para obtenção do título de Doutor em Geografia Humana.

Orientador: Prof. Dr. Ariovaldo Umbelino de Oliveira 
Aos

moradores do assentamento Carlos Lamarca,

Onde não há pecado nem perdão

Ao

Lucas,

É, você que é feito de azul Me deixa eu morar nesse azul

Me deixa encontrar minha paz.

Você que é bonito demais 
"O contrário é conver gente e dos divergentes nasce a mais bela harmonia, e tudo segundo a discórdia"

Heráclito de Éfeso 


\section{AGRADECIMENTOS}

Este é o momento de reconhecer que o trabalho individual é possível graças a muitas pessoas e instituições, cujo auxílio é fundamental. Em primeiro lugar, devo muito a meu orientador, Ariovaldo Umbelino de Oliveira, pela dedicação e atenção e pelos debates. A Maria Regina C. T. Sader, por acompanhar criticamente meu trabalho, pelas orientações no exame de qualificação, pelos seminários no Núcleo Interdisciplinar do Imaginário e Memória (Nime) e por dar exemplo de como fazer geografia. À professora Mirian C. L. Simonetti, pelos comentários no exame de qualificação e pelo trabalho inspirador. Ao professor Donald Black, pelo debate intelectual. Ao professor Boaventura de Sousa Santos, pela inspiração teórica e pela oportunidade de contribuir no projeto Reinventar a Emancipação Social.

Agradeço às funcionárias da secretaria de pós-graduação do Departamento de Geografia da Universidade de São Paulo. Aos funcionários do Laboratório de Aerofotogeografia do Departamento de Geografia da USP.

A Petronella Maria Boonen, pela luta em comum e, especialmente, por ter me apresentado o assentamento. Ao Fausto Ramalho pela companhia no início do trabalho de campo. A Rita de Cássia Somaglia Albino, por compartilhar dados, informações, campo e esperanças. Ao Eduardo Ozi, pelo vôo de ultraleve sobre o assentamento.

Aos amigos e colegas da pós-graduação em geografia agrária: Larissa M. Bombardi, Marco Antonio Mitidiero Jr., Carlos A. Feliciano, Alexandra M. de Oliveira, pelas trocas de informações, de dados e de leituras. Aos colegas Rosemeire A. Almeida, Sérgio Gonçalves e João Fabrini, pelo fornecimento de material. A Bernardo M. Fernandes, pela colaboração e pelos contatos.

A todos os amigos e colegas do Nime, por esses anos de troca intelectual, pelos debates frutíferos, pela rica fonte de reflexão sobre ciência e metodologia e por me sentir em casa. Agradeço especialmente a convivência e a troca de conhecimentos com Maria Luisa S. Schmidt, Maria de Lourdes B. Alcântara, Magali F. Bueno, Marcia Cabreira, Tatiana Freitas S. Neves, Liana C. Soares, Luiz Hildebrando C. Lemos, Beatriz V. Henry. Agradeço muitíssimo a oportunidade de apresentar e debater uma parte desta tese nessa instituição. Os comentários, as sugestões e as cobranças por maior precisão no uso de determinados conceitos foram preciosíssimos. 
Aos funcionários do INCRA, nas pessoas de Elizaide S. Manghirmalani e Márcio. Ao Itesp da cidade de São Paulo, especialmente a João Corsini e Durval Bertolini, e aos funcionários de Sorocaba, que acompanham o assentamento, na pessoa de Magu. Ao diretório nacional do MST, na pessoa de Ney Strozake. A Laíres e Sheila Stanquieri, da direção da regional do MST Grande SP, pelas informações. Aos membros da Fraternidade Povo de Rua, Naveen, Adolar e irmã Alberta, pelas informações, entrevistas e por apresentarem o assentamento. A Rede Rua, nas pessoas de Alderon e Fabiano, pela concessão de entrevista e pela consulta aos exemplares de O Trecheiro.

Aos arquitetos Bruno Nogueira, Ana Paula do Val e Daniela Motisuke, pela valiosíssima conversa sobre a experiência deles no assentamento. A Andréa Urushima, pela riquíssima fonte que foi o seu trabalho.

A Magda e Ricardo Gebrim, pelo fornecimento de dados e materiais, pela entrevista e pelas conversas sobre o assentamento. A irmã Gilda Ferreira, pela grande ajuda em fornecer dados judiciais. Ao Douglas Estevam, pelas informações e por seu trabalho no assentamento. Ao antropólogo Danilo Ramos, por compartilharmos o trabalho de campo. Ao padre Carlos Fritzen, do Centro Pastoral da Juventude.

Ao CNPq.

Devo um agradecimento especial a Claudio Alegre pelo inestimável trabalho de produção digital das figuras presentes nesta tese. Com o trabalho dedicado de Claudio, o acabamento desta tese ficou muito melhor do que poderia ser.

Aos amigos de sempre, por compartilharem mais essa fase: André F. P. Martins e Renata Ferreira, Annie Dymetman, Alberto B. Bendicho, Claudio S. Mungioli e Ernesto Bonato, Fernando L. Fernandes Jr, Flávia Schilling, Iolanda Évora, Sandra L. Goulart e Wânia Pasinato. Aos amigos da Lumiar, por construírem um território de liberdade onde crianças, jovens e adultos convivem felizes.

Aos meus pais e à família do meu irmão, pelo apoio incondicional. À família Singer, pelo suporte e carinho. Ao Paul, pelas "consultas" e conversas sobre a economia solidária e o MST, pelo fornecimento de material e pelo eterno exemplo de integridade de intelectual militante.

A Lena, por além de compartilharmos a vida, pela dedicação com que leu cada uma das versões deste texto, fez correções, comentários, sugestões e debateu interpretações polêmicas, mostrando mais uma vez que estamos ligados por corações e mentes. Uma união assim dá muitos frutos, esta tese é mais um deles. 
Por fim, meu muito obrigado a todos os moradores do assentamento estudado. Um agredecimento especial àqueles que fizeram os belos desenhos de seus sítios.

\section{RESUMO}

Os objetos desta tese são os conflitos internos num assentamento de reforma agrária cuja luta foi organizada pelo Movimento dos Trabalhadores Rurais Sem Terra (MST) e a relação entre a trajetória de ex-moradores de rua da cidade de São Paulo e este movimento de luta pela terra. Foram tratadas duas hipóteses: primeira, a ida para o campo pode ser uma alternativa não-capitalista para o problema social dos moradores de rua; e, segunda, os assentados encontram formas de gerir de maneira pública os conflitos sociais referentes à vida em comum no assentamento. A investigação decorrente destas hipóteses propiciou compreender como se constitui a alternativa e quais são as limitações da gestão do assentamento. Ao longo da tese, comprova-se que o trabalho do MST de conquistar um assentamento possibilita que os moradores de rua criem ondições de vida e de produção que lhes dão indepedência em relação ao mercado de trabalho assalariado. Porém, verifica-se que para a realização de uma alternativa na área da economia solidária é preciso que os moradores de rua cheguem ao assentamento com maior força como grupo, que tenham alguma organização inicial e que estejam ligados a redes. Quanto à segunda hipótese, constata-se que os assentados tanto buscam formas judiciais quanto não-judiciais de gestão dos conflitos internos e que há o potencial de uma gestão pública do assentamento com relativa autonomia em relação ao Estado. No entanto, entre aos moradores o aprendizado de formas democráticas de gestão de conflito ainda é incipiente.

Demonstra-se como os conflitos internos configuram o território, mapeando as redes de alianças e ataques entre os assentados. Neste sentido, contribui-se para os estudos geográficos sobre a fração de território camponês acrescentando a noção de redes como componente central da dinâmica da disputa de poder no assentamento.

Problematiza-se a questão do ethos camponês como elemento de aptidão para a permanência como assentado. Mostra-se que o ethos é objeto de disputa entre os assentados, que reivindicam entre si maior legitimidade como camponês.

Palavras-chave: camponês; morador de rua; MST; conflitos sociais; justiça social. 


\begin{abstract}
This dissertation has two subjects. First, the social conflicts inside an agrarian reform settlement. Second, the relationship between the personal trajectory of the homeless people living in São Paulo city and the Rural Workers Landless Movement (MST). There are two hypotheses: the Landless Movement (MST) can be a noncapitalistic alternative to homeless people and there is a possibility of creating a public sphere to manage the social conflicts related to settlement organization. The investigation showed how that alternative can be built and what the limits to public management of the settlement are.

The conquest of a piece of land by MST work gives the opportunities to the homeless to create ways of living and of production, instead of waiting for a job. But, the homeless people need to be organized and connected to a network to have the opportunity of building a kind of "solidarity economy", in a socialistic term. Related to the second hypothesis, it was observed that there are judicial and non-judicial forms of conflict management. There is the potential for a public sphere to manage the social conflicts autonomously in relation to the state. Anyway, among the settlers, the learning of how to deal with social conflicts in a democratic way is a process in its first steps.

The dissertation shows that the settlement as territory is shaped by social conflicts, by mapping alliances and attacks between the settlers. One theoretical contribution of this dissertation is the use of the notion of network as a complementary form for the territory concept.

The dissertation demonstrates that the peasant ethos is a subject of dispute between the settlers. Who use this to legitimate their position as peasant or to not legitimate the position of the others, like the ones who came from the streets.
\end{abstract}

Key-words: peasant; homeless; Landless Rural Workers Movement (MST); social conflict; social justice 


\section{SUMÁRIO}

Apresentação 1

Introdução 4

Do objeto e seu contexto 4

Objetivos e método 12

Questões e hipóteses 16

Reflexões sobre metodologia 20

Parte 1 - a teoria $\quad 37$

1. Camponês, morador de rua e justiça social no centro da modernidade $\quad 38$

As visões modernas sobre camponês e morador de rua 38

Modo de vida camponês e a inclusão de moradores de rua na luta pela terra 49

2. A vida nas ruas de São Paulo: interpretações, dados e análises 55

Problematizando o tema $\quad 55$

$\begin{array}{ll}\text { O perfil do morador de rua em São Paulo } & 67\end{array}$

Alternativas sociais: MST, MTST e Cooperativas $\quad 70$

3. Controvérsias na ciência:

geografia da produção acadêmica sobre assentamentos

Temas e questões presentes nos trabalhos sobre assentamentos $\quad 75$

Os ritmos dos assentados: união, desunião e reunião 95

Generalizações sobre a luta do MST: dos conflitos internos para

os conflitos com o capital - a emancipação camponesa 96

Parte 2 - a empiria 103

4. Em campo: união, desunião e reunião 104

$\begin{array}{ll}\text { Primeiras impressões e paisagem local } & 105\end{array}$

$\begin{array}{ll}\text { Primeiras interpretações e a presença do pesquisador } & 119\end{array}$

5. Conflitos, trajetórias e redes 130

$\begin{array}{ll}\text { As controvérsias recriando redes } & 131\end{array}$

Redes: outra associação e um grupo 146

As categorias de acusação e o ethos camponês $\quad 154$

A dinâmica das invalidações recíprocas e seu oposto 156

$\begin{array}{ll}\text { Algumas inferências } & 157\end{array}$

6. Entre campo e dados: as formas de lidar com conflitos sociais 165

$\begin{array}{ll}\text { Três formas de lidar com o conflito } & 167\end{array}$

Poder e território - tessituras, nós e redes 176

Parte 3 - a teoria e a empiria 184

7. Teoria e empiria em ressonância $\quad 185$

$\begin{array}{ll}\text { Conflito, democracia e justiça social } & 185\end{array}$

$\begin{array}{ll}\text { Modernidade, campesinato e ciência: território e rede } & 187\end{array}$

Morador de rua como camponês, conflitos e gestão 199

$\begin{array}{ll}\text { Abstrações e continuidade da luta } & 209\end{array}$

$\begin{array}{ll}\text { Possíveis generalizações } & 212\end{array}$

$\begin{array}{ll}\text { Considerações finais } & 214\end{array}$

Das questões e do objeto $\quad 214$

Das teorias $\quad 215$

$\begin{array}{ll}\text { Da empiria } & 217\end{array}$

$\begin{array}{ll}\text { Das respostas } & 219\end{array}$

Referências bibliográficas $\quad 226$ 


\section{ÍNDICE DE FIGURAS E FOTOS}

Figura $1+34$

Figura $2 \quad 35$

Figura $3 \quad 36$

$\begin{array}{ll}\text { Figura } 4 & 123\end{array}$

$\begin{array}{ll}\text { Figura } 5 & 124\end{array}$

$\begin{array}{ll}\text { Figura } 6 & 125\end{array}$

$\begin{array}{ll}\text { Figura } 7 & 126\end{array}$

$\begin{array}{ll}\text { Figura } 8 & 127\end{array}$

$\begin{array}{ll}\text { Figura } 9 & 159\end{array}$

$\begin{array}{ll}\text { Figura } 10 & 160\end{array}$

$\begin{array}{ll}\text { Figura } 11 & 161\end{array}$

$\begin{array}{ll}\text { Figura } 12 & 162\end{array}$

$\begin{array}{ll}\text { Figura } 13 & 183\end{array}$

$\begin{array}{lr}\text { Foto } 1 & 128\end{array}$

$\begin{array}{lr}\text { Foto } 2 & 129\end{array}$

$\begin{array}{lr}\text { Foto } 3 & 129\end{array}$

$\begin{array}{ll}\text { Foto } 4 & 163\end{array}$

$\begin{array}{ll}\text { Foto } 5 & 163\end{array}$

Foto $6 \quad 164$

$\begin{array}{ll}\text { Foto } 7 & 213\end{array}$ 


\section{A presentação}

Este trabalho consiste de um estudo sobre conflito social, ciência e justiça, mais especificamente sobre o papel dos conflitos agrários nas contradições da sociedade moderna. Os objetivos são interpretar a luta camponesa (uma face da luta expressa-se no jogo de definir quem é e quem não é camponês), as formas de lidar com conflitos sociais referentes à organização da vida coletiva e realizar uma reflexão epistemológica sobre ciência e justiça social.

As questões trabalhadas no mestrado (JUSTO, 2002) continuam a ser norteadoras: encontrar no campesinato elementos de produção não-capitalista e de relações sociais antiautoritárias, no sentido de dizer "não" a determinadas imposições ou situações - como trabalhado por Antonio Candido (1998) ou Eric Wolf (1979) -, e de lutar por justiça social. A diferença trazida aqui, porém, é tratar dos conflitos sociais internos e não mais o conflito entre camponês, proprietário e Estado. O termo "camponês" é usado como um conceito, sendo uma classe social que é recriada dentro do modo de produção capitalista e, portanto, não se extingue.

O estudo é baseado na análise de um assentamento do Movimento dos Trabalhadores Rurais Sem Terra (MST), num município do sudoeste paulista, com uma parcela de ex-moradores de ruas da cidade de São Paulo e com outras que viviam nas cidades. O que está em pauta são pessoas que saíram do centro urbano, onde eram excluídas do mercado formal de trabalho, e foram para o campo, como uma forma de "resgatar" (ou viabilizar) um modo de vida baseado no trabalho com a terra. O caso estudado, então, abre um leque de indagações sobre as formas de se lidar com problemas de justiça social e conflitos sociais.

Nos conflitos agrários encontram-se ações e reações em relação à injustiça na distribuição de meios de trabalho e de reprodução da vida. O problema central que se apresenta à investigação é a relação conflito - justiça. Há uma parcela da população brasileira, conceitualmente classificada como camponesa, que luta pelo acesso a meios de produção (de bens materiais e culturais) e, principalmente, por justiça.

O nome da tese, "Exculhidos", surgiu com o trabalho de campo. Um dos principais interlocutores procurou formar uma associação de produção agrícola no assentamento estudado e deu um nome ao grupo que me soou algo como a fusão entre "os escolhidos" e “os excluídos". Parecia que ele pronunciava "errado" a palavra "excluído". No entanto, ele 
narrou que ao contar para um padre local o nome do grupo, falou em tom irônico: "nós, os 'esculhidos', padre!?”; ao que este teria respondido: “como vocês podem dizer que são os escolhidos?" Em outros dias, mencionava o grupo como sendo "excluídos”, mas em alguns momentos parecia querer dizer "os escolhidos".

Ao invés de procurar "corrigi-lo" ou lhe perguntar qual era o nome exato, preferi trabalhar com uma tradução pessoal que tentasse expressar a sonoridade evocada pelo interlocutor, e que também fosse a fusão das palavras "escolhido" e "excluído". Interessa fazer ressoar a provocadora ambivalência de os excluídos serem os escolhidos. Não se trata de uma tese sobre a exclusão social, mas de um exercício de colocar os "lumpens" no ponto central para a compreensão do movimento social de exclusão.

Com este trabalho, procura-se analisar como a ida para o campo pode constituir-se como uma alternativa para um problema vivido na cidade. Mostrar como a configuração espacial de um assentamento é moldada pelos conflitos sociais internos. Contribuir no debate sobre o conceito de território como elemento chave na análise geográfica da luta pela terra, mostrando - com base na obra de Claude Raffestin - que esse conceito deve estar acompanhado da noção de rede. Assim, abre-se o foco para novos referenciais dentro dos paradigmas sobre a questão agrária.

Vale observar que foram trocados os nomes de moradores, do assentamento e dos municípios onde está localizada a fazenda e do entorno e foram retiradas das figuras as possibilidades de identificação do local, no sentido de preservar as pessoas envolvidas e o movimento de luta pela terra e mostrar com maior transparência os fatos. São tratados os conflitos sociais num assentamento organizado pelo MST de uma perspectiva que os mesmos são inerentes às relações sociais; porém, encontram-se no local situações conflituosas específicas. Neste sentido, este trabalho visa contribuir para a reflexão sobre as formas de lidar com os conflitos sociais num assentamento e sobre a possibilidade de aprendizagem de novas formas. A possibilidade vislumbrada é que as associações são vitais na gestão política do assentamento. Como será visto, essa preocupação está amparada na discussão metodológica, em que se aponta para o compromisso da ciência com a justiça social.

$* * *$

A tese está dividida em três partes, além da introdução. Na primeira são tratadas as questões teóricas, a problematização do tema e as questões sociais envolvidas e consiste 
em três capítulos. A segunda parte é composta de três capítulos que abrangem o trabalho de campo. Na terceira, é construída uma ponte analítica entre a discussão teórica da primeira e a empiria da segunda.

Na introdução, é apresentado o objeto de estudo e seu contexto espacial e histórico. Colocam-se duas hipóteses de trabalho: como o MST constitui-se como uma alternativa para os moradores de rua e como é possível a formação de um espaço comum para a gestão dos conflitos internos referentes à vida pública. Trabalha-se a idéia de alternativa no sentido de proporcionar aos ex-moradores de rua a formação de um modo de vida e de produção não-capitalista. Consta também da introdução uma discussão metodológica sobre a relação entre pesquisador e pesquisado, a possibilidade de acesso ao sentido do outro, o poder da ciência e a ética na pesquisa e a relação entre ciência e justiça social.

No primeiro capítulo são tratadas as formas de o pensamento moderno analisar camponês e morador de rua. É feita uma crítica ao registro moderno por meio das interpretações contemporâneas sobre aqueles dois sujeitos sociais e é colocada a possibilidade de um assentamento de reforma agrária consolidar-se como um local de justiça social. No segundo capítulo são expostas as interpretações e análises sobre moradores de rua, são expostos dados sobre essa população na cidade de São Paulo e são tratadas as alternativas. As questões sobre território e ethos de camponês são analisadas no capítulo três, por meio de um debate com os trabalhos da área.

Um panorama do assentamento e do trabalho de campo é o conteúdo do quarto capítulo, cujo foco está na dinâmica de união-desunião entre os moradores. O cerne do quinto capítulo está nos conflitos internos e na formação de grupos e associações. A trajetória da população proveniente das ruas de São Paulo também é destacada e a questão de como o MST pode ser uma alternativa a essa população é respondida. As formas de gerir os conflitos são descritas, classificadas e interpretadas no sexto capítulo e, assim, pôde-se esgotar as questões decorrentes de como se constitui uma gestão pública dos conflitos.

O sétimo capítulo é de análise da empiria com base na teoria da primeira parte. É possível comprovar que a noção de rede contribui para a análise dos conflitos internos que moldam a fração de território, que o ethos camponês é objeto de disputa entre os assentados e que há um potencial para se aprender a gestão democrática dos conflitos e para se inserir numa rede de economia solidária. No último capítulo são tecidas as considerações finais. 


\section{Introdução}

In a democracy scientific institutions, research programs, and suggestions must therefore be subjected to public control, there must be a separation of state and science just as there is a separation between state and religious institutions, and science should be taught as one view among many and not as the one and only road to truth and reality.

Paul Feyerabend (1993)

\section{Do objeto e seu contexto}

$\mathrm{O}$ objeto empírico desta pesquisa constitui-se dos conflitos internos relativos à organização da vida coletiva $^{1}$ em um assentamento de reforma agrária organizado pelo MST, no município de Irene, estado de São Paulo. Em outras palavras, trata-se da possibilidade de formação de um espaço público no assentamento.

A peculiaridade desse assentamento é ter pessoas que estavam morando nas ruas da cidade de São Paulo. No caso tratado, inicialmente cerca de 250 famílias compunham essa luta, sendo que 27 indivíduos desse total moravam nas ruas (Cf. O TRECHEIRO, No. 36, Ano VI, Set/1996, p. 3). Do grupo original, cerca de 80 famílias ocuparam a fazenda Monte e lá permaneceram 63. Com a desapropriação de 920,5 ha, apenas 47 famílias puderam ser assentadas no local. Destas, permaneceram 12 pessoas que são ex-moradores de rua. A relação entre a trajetória de vida daqueles que vieram das ruas e o MST também é objeto de pesquisa. De acordo com levantamento bibliográfico, esse tema é quase inexplorado na geografia; outros trabalhos trataram do assentamento estudado ou de ocupações com ex-moradores de rua, mas sem privilegiar esta questão (URUSHIMA, 2000; ALBINO et alli, 2001; IHA, 2001; FELICIANO, 2003; MATHEUS, 2003). Na área de sociologia, há o trabalho de Barros (2004), que trata da problemática dos moradores de rua na cidade de São Paulo e estuda a ida de alguns deles para o assentamento D. Tomás Balduíno.

A escolha do assentamento deve-se ao fato de ser um dos primeiros do experimento de levar moradores de rua para o campo e de ter um número significativo desses indivíduos que permaneceram no local.

\footnotetext{
${ }^{1}$ Quando se enfatiza que o objeto de estudo é conflito interno relativo à organização da vida coletiva, está-se excluindo do tema os conflitos interpessoais, como as brigas de vizinhos, por exemplo, mesmo sabendo que, às vezes, não há limite entre esses dois tipos de conflitos.
} 
O recorte temporal do trabalho de campo cobre os anos de 2001 a 2004. Retratamse a vida e os conflitos vividos nesse período. Recorre-se a relatos orais e a documentos para cobrir o período anterior necessário para se compreender a situação atual.

Antes de expor o contexto do objeto estudado, vale explicar que um “assentamento" é uma criação do Estado, no âmbito federal ou estadual, através de uma política específica de reforma agrária baseada, principalmente, na Constituição Federal (1988) e no Estatuto da Terra (1964). O particular dessa política de "reforma agrária" é que os assentamentos são, geralmente, decorrentes de desapropriações provocadas por conflitos de terra, ocupações etc. Portanto, o fato de no título da tese constar "assentamento do MST" enfatiza-se que é um local criado pelo Estado em decorrência da ação de um movimento social e organizado por este. Logo, várias questões estão implicadas porque o MST tem uma história de mais de 20 anos, tem seus objetivos e, principalmente, com a escala que a organização do movimento adquiriu, passou a plasmar nos camponeses (ou, trabalhadores rurais) uma linguagem própria ${ }^{2}$. Como definição de assentamento, segue-se a de Carvalho (1998, 1999), que aponta para o fato de ser produto de ação governamental e da pressão da luta pela terra:

Como assentamento, enquanto substantivo, compreende-se o conjunto de famílias de trabalhadores rurais vivendo e produzindo num determinado imóvel rural, desapropriado ou adquirido pelo governo federal (no caso de aquisição, também, pelos governos estaduais) com o fim de cumprir as disposições constitucionais e legais relativas à reforma agrária. A expressão assentamento é utilizada para identificar não apenas um área de terra, no âmbito dos processos de reforma agrária, destinada à produção agropecuária e ou extrativista mas, também, um agregado heterogêneo de grupos sociais constituídos por famílias de trabalhadores rurais (CARVALHO, 1998: 7; 1999: 5; grifo do autor).

O autor traz a discussão de que o assentamento, após a desapropriação, precisa ser construído, não somente no sentido da infra-estrutura - dever do Estado - como na de formação de laços e identidades sociais (CARVALHO, 1999: 5-6). É preciso notar também, como observa Simonetti (1999: 1), que a expressão "assentamentos rurais" está comprometida com a atuação estatal de colonização, desde a década de 1960, porém, a partir dos anos 80, ela é apropriada pela luta camponesa ${ }^{3}$.

\footnotetext{
2 Sobre a história, os objetivos e a espacialização da luta do MST há várias referências; entre as mais completas, ver Fernandes (1996).

${ }^{3}$ Vale observar que, segundo Ferreira (1994: 39-40), o termo "assentamento" passou a ser usado pelo Estado a partir do I PNRA (Plano Nacional de Reforma Agrária, de 1985) e, em 1987, o Ministério da Reforma Agrária e o INCRA realizam um publicação intitulada Política de Assentamento. Até esse período, prossegue a autora, o termo usado pelo governo federal era "colonização", em decorrência da falta de uma política clara
} 
Os assentamentos são porções do território do Estado, pois, ao desapropriar uma área privada, o INCRA (Instituto Nacional de Colonização e Reforma Agrária) é imitido na posse do imóvel. Porém, nessas frações de território camponês, como denomina Oliveira (1997), encontram-se dinâmicas de poder em relação ao controle estatal. Estas dinâmicas moldam a tessitura, os nós e as redes do território, conforme Raffestin (1993) trabalha 4 .

No processo de assentar famílias de agricultores sem terra, o INCRA estabelece duas etapas: pré-assentamento e assentamento. O pré-assentamento é a fase de formação do assentamento, do momento de desapropriação em diante, quando são feitos os serviços de infra-estrutura como redes de água e luz, abertura de estradas e ruas, demarcação de lotes ou agrovila e liberação de créditos de fomento, alimentação e habitação. Essa fase corresponde, em média, aos dois primeiros anos. Depois, inicia-se a etapa de assentamento, quando os moradores já estão instalados e produzindo. Essa distinção entre as fases de préassentamento e assentamento aparecerá ao longo dos capítulos que tratam do trabalho de campo.

\section{Ação aliada entre Fraternidade Povo da Rua e MST}

O trabalho do MST de promover ocupações de terra com pessoas que vivem nas ruas de São Paulo começou em 1994, através da aproximação do trabalho da Fraternidade Povo da Rua (cujos membros são, em parte, da Congregação do Verbo Divino) ${ }^{5}$ com o MST, criando um centro de formação deste movimento no bairro do Brás (Cf. IHA, 2001).

A Fraternidade Povo da Rua começou a atuar com a população de rua no início dos anos 1990 fazendo um trabalho de prevenção a doenças sexualmente transmissíveis e de ajuda aos portadores do vírus HIV. A trajetória inicial da Fraternidade está interpenetrada pela Rede Rua de Comunicação.

de reforma agrária presente no Estatuto da Terra (1964). A "colonização" teria um caráter paternalista, enquanto que o "assentamento de reforma agrária" pressupõe maior participação, conclui a autora.

No caso da Lei de Revisão Agrária (No. 5994), de 1960, do estado de S. Paulo, o termo usada para os assentamentos era "núcleo agrário" (BOMBARDI, 2001).

${ }^{4}$ Sobre Raffestin, ver o item: Reflexões sobre metodologia.

${ }^{5}$ Os principais membros da Fraternidade Povo da Rua, entre outros, são: o ex-padre indiano Naveen Manikkompel, que foi da Congregação do Verbo Divino; o padre Arlindo Pereira Dias, da Congregação do Verbo Divino e presidente fundador da Rede Rua de Comunicação, e a irmã italiana Alberta Girardi, da Congregação Dom Orione. Naveen veio da Índia em 1990 e começou a atuar na Fraternidade Povo da Rua, desde 1992, em trabalho com a população moradora de rua e portadora do vírus HIV, fez parte da Comunidade do Verbo Divino, foi ordenado padre em novembro de 1995 e, atualmente, continua a militância não mais como padre e é membro da direção regional do MST Grande S. Paulo. Irmã Alberta veio de Veneza para a região do norte do rio Araguaia, próximo a Araguaína no atual estado de Tocantins, em 1970, trabalhou por três anos com Pe. Josimo Moraes Tavares (personagem notório da luta pela terra assassinado em 1986 por defender posseiros do Bico do Papagaio) e ajudou a fundar a CPT. 
Segundo entrevista com Alderon Pereira da $\operatorname{Costa}^{6}$ (ex-seminarista da Congregação do Espírito Santo e membro fundador da Rede Rua), a Rede Rua de Comunicação tem seu embrião em 1982 com Pe. Arlindo Pereira Dias e outro ex-padre verbita, mais Alderon e uma Irmã agostiniana. Nessa época, as Irmãs Oblatas de S. Bento mudaram historicamente o enfoque do trabalho com população de rua porque cortaram a ação assistencialista, foram conhecer a realidade de morar nas ruas e em albergues e criaram a prática de organizar um "sopão" feito pelo povo da rua com sobras de feiras. Alderon, então seminarista, começou a participar desse processo de trabalho com as Irmãs, em 1982. Após a sopa, ele conversava com a população e percebeu que a fala "não entrava"; então, os organizadores começaram a usar de teatro, música e imagens e depois formularam um projeto de trabalhar com fotografias. Pe. Arlindo juntou-se ao grupo em 1988, interessou-se pelo trabalho com imagens (filmes e fotos) e criou um jornal, o Jornal de Rua. Em 1990, foi oficializada a entidade Centro de Documentação e Comunicação dos Marginalizados, que se chamaria mais tarde de Rede Rua de Comunicação, que começou a fazer o jornal O Trecheiro e assumiu uma casa de atendimento à população de rua. Naquele ano, a Rede Rua funcionava na torre da igreja Bom Jesus do Brás, mesmo local onde a futura Fraternidade Povo da Rua reunir-se-ia. Por volta de 1993, a Rede Rua e as pessoas que trabalhavam com o nome Fraternidade AIDS na Rua atuavam juntas na campanha de prevenção de doenças sexualmente transmissíveis. Foi nesse contexto que a Fraternidade Povo da Rua virou uma entidade independente e que, em 1994, organizou o grupo de moradores de rua que participou da luta pela terra em Itapeva. Então, houve a necessidade de distinguir a ação da Fraternidade Povo da Rua do trabalho de comunicação da Rede Rua. Logo, em 1994, oficializou-se a Rede Rua, separando-se juridicamente da Fraternidade. A Fraternidade Povo da Rua aproximou-se, efetivamente, da ação do MST após a primeira ocupação com pessoas da rua, por ter percebido que era preciso oferecer uma saída para a população com quem trabalhavam.

A primeira ocupação com moradores de rua ocorreu em 20 de dezembro de 1994 no município de Itapeva (270 km a sudoeste da capital). Um grupo de 15 moradores de rua estava se reunindo havia seis meses na igreja “da Torre" (Bom Jesus do Brás), sendo que 13 deles juntaram-se a mais de 200 famílias para ocuparem a fazenda Pirituba, com 17 mil ha, em Itapeva (Cf. O TRECHEIRO, No. 16, Ano V, Jan.1995, p. 2) ${ }^{7}$. Dos 13 provenientes das ruas de S. Paulo restaram, em 1995, quatro pessoas, após um ano de acampamento (Cf.

\footnotetext{
${ }^{6}$ Entrevista concedida em 02/09/2004.

${ }^{7}$ Para um histórico da luta na fazenda Pirituba, em Itapeva, ver Fernandes (1996: 114-6).
} 
O TRECHEIRO, Especial "Sem-Terra", Ano V, p.2). Em 1995, houve uma tentativa de levar moradores de rua para Andradina. Em 2003 contabilizava-se, entre acampamentos/ assentamentos com ex-moradores de rua, uma soma de 10 unidades. Além do caso estudado em Irene e dois mencionados acima, há um no Pontal do Paranapanema, dois no município de Iaras ${ }^{8}$, um em Bauru, um em São José dos Campos, um em Jacareí, um em Barretos e um em Ribeirão Preto.

Por fim, entre 1999 e 2000, o MST criou na cidade de S. Paulo a regional Grande S. Paulo, em decorrência do trabalho do centro de formação no Brás levado pelo "coletivo" de militantes do MST e da Fraternidade Povo da Rua. Essa regional é a responsável pelo assentamento D. Tomás Balduíno ${ }^{9}$, em Franco da Rocha, e pelos acampamentos Irmã Alberta, na divisa de S. Paulo com Cajamar, Camilo Torres e D. Pedro Casaldáliga, numa mesma fazenda em Pirapora do Bom Jesus.

A partir do final da década de 1990, as regionais do eixo metropolitano do MST (Grande S. Paulo, Campinas e Vale do Paraíba) começaram a implementar a proposta de Comunas da Terra, que consiste em ocupações próximas aos grandes centros urbanos visando abastecê-los, as famílias moram em pequenos lotes (de 2 a 5 ha) formando núcleos familiares e produzem em áreas coletivas. As experiências até o momento são: assentamento Nova Esperança, em S. José dos Campos, de 1998, com 60 famílias em 447 ha; assentamento D. Tomás Balduíno, em Franco da Rocha, de 2001, com 180 famílias em 850 ha; acampamento Terra Sem Males, em Cajamar, com 220 famílias, desde 2002; acampamento Irmã Alberta, na divisa de S. Paulo com Cajamar, com 300 famílias em 250 ha, desde 2002 (Cf. MATHEUS, 2003: 42-50). Vale destacar que, pelo menos, o assentamento D. Tomás Balduíno e o acampamento Irmã Alberta são formados predominantemente por ex-moradores de rua. Porém, a orientação do trabalho dessas regionais é voltada para a população "marginalizada" em geral e não apenas para moradores de rua ${ }^{10}$.

\footnotetext{
${ }^{8}$ Para exemplificar, o assentamento Nova Canudos, no município de Iaras, era um acampamento, em 1999, com cerca de 1200 famílias e, em 2001, restaram pouco mais de 250 famílias e a área está desapropriada. Sobre o assentamento Nova Canudos, ver: Iha (2001); Folha de S. Paulo, Sem-terra urbanos completam um ano. São Paulo, 6/2/2000, p. A-15, e Jornal do Campus, A Resistência do MST. São Paulo, 10/10/2000, pp. 4-5.

${ }^{9}$ Sobre a presença de ex-moradores de rua no assentamento D. Tomás, ver Barros (2004).

${ }^{10}$ Entre julho de 1998 e junho de 1999, o MST Grande S. Paulo organizou três congressos Da Rua para a Terra, com a participação de moradores de rua e de assentados que vieram das ruas.
} 
Histórico da luta ${ }^{11}$ e localização da fazenda

Desde abril de 1996 membros da organização pastoral católica Fraternidade Povo de Rua e militantes do "coletivo do Brás" do Movimento dos Trabalhadores Rurais Sem Terra (MST) promoviam conversas com cerca de 45 moradores de rua sobre as ações de ocupação de terras e conseguiram articular um grupo de 27 pessoas disposto a se unir a outros interessados em lutar por terra.

Em 2 de setembro de 1996, esses 27 moradores de rua e mais dezenas de famílias partiram para as imediações dos municípios de Alencar e Irene, região sudoeste do estado. Ao todo eram mais de 200 famílias, sendo uma grande parte proveniente da capital e da região de Campinas, de municípios como Hortolândia e Sumaré, e outras da região de Sorocaba organizadas pelos respectivos núcleos do MST destas três regiões ${ }^{12}$. Ocuparam a fazenda Cercadinho, de 34,8 mil ha em Alencar ${ }^{13}$. Segundo relatos, na época o número de famílias acampadas oscilava entre 500 e 800 . Ficaram acampados por quinze dias quando tiveram de sair diante de reintegração de posse. Acamparam na beira de uma estrada intermunicipal por cerca de um mês e, diante da proximidade do Natal, decidiram ocupar a fazenda Rocinha, na mesma região, por dois meses. Com a reintegração de posse, ocuparam a Escola Agrícola de Irene, durante o período das férias letivas, com a intenção de denunciar uma situação de abandono da coisa pública. Após o início das aulas, ficaram acampados numa área ao fundo da Escola Agrícola. Depois, acamparam na beira da estrada para o presídio de Irene, onde ficaram durante 11 meses. No início desse acampamento havia algo em torno de 300 famílias, pois muitas desistiram da luta, e, ao longo do período, outras foram abandonando o acampamento.

Após um ano e meio de luta e sete acampamentos distintos, em fevereiro de 1998, de cerca de cento e poucas famílias que estavam acampadas na beira da estrada, em torno de 80 decidiram ocupar a fazenda Monte. O restante de trinta e poucas famílias continuou acampado na beira da estrada aguardando por situação mais definida ${ }^{14}$.

\footnotetext{
${ }^{11}$ A reconstrução do histórico da luta foi baseada no cotejamento das fontes orais com os textos de Urushima (2000), de Albino et alli (2001) e dos jornais O Trecheiro No. 36, Ano VI, Set/1996, p. 3; No. 56, Ano VII, Jul/1998, p. 3; No. 62, Ano IX, Fev/1999. Também é possível acompanhar a narração dos vários acampamentos até a ocupação da fazenda desapropriada por um dos assentados no vídeo: Assentamento Clarice Lispector -2001, produzido por Albino et alli (2001).

${ }^{12}$ Foge do objeto desta tese refazer o histórico dos grupos que não são formados por moradores de rua.

${ }^{13}$ Ver a cadeia dominial da fazenda em: Jornal do Campus, "Dona Olívia: uma latifundiária marreteira". São Paulo, 10/10/1996, p. 7.

${ }^{14}$ Segundo Feliciano (2003: 168), um grupo de famílias que estava acampado em Irene partiu para uma ocupação no Núcleo Colonial Monções, no município de Iaras/SP, em 15/08/98.
} 
A ocupação dessa fazenda, localizada no bairro Lagoa Vermelha do município de Irene, microrregião Campos de Irene, deu origem ao assentamento Clarice Lispector. Encontra-se no limite leste daquela cidade, na divisa com o município de Sapé, separado pelo rio Irene, conforme figura 1. O local está circunscrito por duas outras fazendas, pelo rio Irene, pelos córregos Tapera e Monte e pelo riacho do Lagoão. O acesso principal ao assentamento dá-se por estrada de terra, a $8 \mathrm{~km}$ de Sapé. Há outro acesso com origem em Irene, sendo $10 \mathrm{~km}$ de asfalto e mais $10 \mathrm{~km}$ de terra.

No entorno do assentamento há duas fazendas, uma com plantação de eucalipto arrendada por uma indústria de papel e outra pertencente ao governo do estado para pesquisas com Pinus elliot, chácaras de veraneio, sítios de pequenos agricultores e área de extração de areia do rio Irene. As terras da região são usadas para pastagem e de baixa fertilidade, conforme laudo técnico do INCRA. Na figura 2 é possível observar a demarcação da fazenda numa foto aérea do início dos anos 1960, quando o entorno da área diferia um pouco dessa descrição.

Acamparam na fazenda cerca de 80 famílias, pois o grupo inicial havia se dispersado, sendo que alguns desistiram da luta e outros foram para ocupações distintas. O governo federal desapropriou a fazenda um mês depois, em março de $1998^{15}$. Restaram na fazenda 63 famílias $^{16}$. Segundo relatos, a fazenda estava nas mãos de herdeiros do falecido proprietário, que tinham interesse na "venda". Nela havia poucas cabeças de gado e uma área estava arrendada para plantação de melancia.

Em 25/08/1998, o INCRA fez a seleção das famílias a serem assentadas e excluiu três pessoas através da entrevista técnica por considerá-las inaptas para o trabalho no campo. O órgão fez uma lista de pessoas que poderiam ser homologadas e das que não. Os pré-assentados apelaram contra tal exclusão e se dispuseram a dividir seus futuros lotes para mantê-los no grupo.

Em 18/12/1998, foi assinado pelo governo federal o projeto de crédito fomento ${ }^{17}$. Os técnicos do INCRA verificaram, inicialmente, a capacidade de assentar 41 famílias, dadas a baixa fertilidade do solo e a localização afastada da fazenda, o lote mínimo deveria ter 12 ha. Em assembléia do projeto de assentamento de 14/12/1998, os presentes, já

\footnotetext{
${ }^{15}$ Decreto do Presidente da República e do Ministro do Desenvolvimento Agrário de desapropriação do imóvel rural para fins de reforma agrária, em 09/03/98. Em 22/09/98 foi decretada pelo governo federal a criação do projeto de assentamento e, em 18/12/98, foi assinado o projeto de crédito fomento. Dados obtidos com a consulta ao Processo de Criação do Projeto de Assentamento Clarice Lispector, na superintendência regional do INCRA/SP.

${ }^{16}$ Utiliza-se o termo "família", mas há também indivíduos sozinhos que recebem um lote. Nem todos os indivíduos sozinhos são ex-moradores de rua e nem todos os que vieram das ruas vivem sozinhos.
} 
sabendo da liberação da verba de fomento, decidiram sobre a partilha do montante entre todos que participaram da luta mesmo que não fossem assentados ali. Decidiram que o dinheiro, que viria para 41 famílias, seria dividido entre as 63 e que as 22 excluídas da lista do INCRA devolvessem o dinheiro quando fossem beneficiadas pelo mesmo tipo de financiamento. Esta partilha do financiamento de fomento gerou, três anos depois, um grande conflito no assentamento, como será visto no quinto capítulo.

Posteriormente, o INCRA decidiu assentar 47 famílias e fez uma lista homologando as mesmas. Nessa época, estavam morando 61 famílias, sendo que as 14 não homologadas pelo instituto dividiam a área com outras. Alguns indivíduos sozinhos cansaram da espera pela divisão dos lotes: quatro desistiram da luta e cinco foram para um assentamento no município de Iaras. Um ex-morador de rua que estava entre aquelas 47 famílias faleceu e o governo, então, assentou uma família que havia ficado na lista de espera.

O clima entre os pré-assentados nessa época era muito tenso e havia ameaças pessoais. Uma parte queria o trabalho coletivo e moradia em agrovila e outros preferiam morar e trabalhar em lotes individuais. A espera pela demarcação dos lotes causava uma animosidade entre os moradores.

Da desapropriação, em março de 1998, até a divisão dos lotes, em janeiro de 2000, a grande maioria das famílias estava morando numa espécie de agrovila e trabalhando coletivamente numa estufa de pimentões. Outros poucos estavam morando em áreas mais afastadas.

Os moradores decidiram a divisão dos lotes por meio de sorteio, em assembléia geral de 9/1/2000. Nessa assembléia, 14 moradores comprometeram-se em dividir seus lotes com os outros 14 não homologados pelo INCRA. Quem ficasse com o lote onde se encontravam a agrovila e a estufa deveria conceder 12 meses para desocupação das áreas. Decidiram que 4 ha seriam destinados à sede e 8 ha para a construção de uma agrovila. No entanto, a construção da agrovila foi um motivo de conflitos no pré-assentamento e não veio a ocorrer.

Coube a cada uma das 47 famílias um lote de aproximadamente 12 ha, sendo 534,5 ha de área agrícola. A área total desapropriada é de 920,5 ha, mas 42\% disto envolvem áreas de reserva $(40,5 \%$ do total), da sede $(0,45 \%)$ e estradas $(1 \%)$. Três lotes fugiram à regra dos 12 ha, uma família ficou com 8 ha, deixando 4 ha para a área da sede da fazenda

\footnotetext{
${ }^{17}$ Cada família tinha direito a R \$ 1.425,00 para instalação no lote e primeiro plantio, a fundo perdido.
} 
e dois homens sozinhos obtiveram 7,3 e 4,1 hectares. Ver a configuração da área e a divisão dos lotes no figura 3.

O trabalho de Urushima (2000), um projeto arquitetônico de agrovila para o assentamento Clarice Lispector, descreve o problema decorrente do fato de não se poder assentar todas as famílias acampadas na fazenda. Os técnicos da Concrab (Confederação das Cooperativas de Reforma Agrária do Brasil) do MST contestaram o primeiro laudo técnico do INCRA, que destinava a área somente a 41 famílias, dizendo que era possível ter uma agricultura "mais rentável" em lotes menores. Os acampados não queriam abrir mão de assentar todas as famílias. A equipe técnica do INCRA não aceitou essa argumentação. No entanto, em assembléia geral, as duas equipes aceitaram a posição do órgão federal de homologar 47 famílias, desde que aqueles que eram sozinhos dividissem suas áreas com outras famílias. O que ocorreu temporariamente. Houve então um conflito entre assentados e governo. Um outro conflito, agora interno, ocorreu no início do projeto de assentamento. Foi entre as famílias com maior participação no MST (congressos, ocupações etc.), que queriam morar em agrovila e trabalhar coletivamente e as famílias que queriam morar nos lotes isolados e produzirem para o próprio consumo. Segundo Urushima (2000), 27 pessoas não pretendiam morar em agrovila e 17 sim; 21 defendiam a produção "individual”, 14 a coletiva, 8 a semi-coletiva e 2 não sabiam.

Essa autora mostra um perfil da população. De 49 pessoas entrevistadas, 40 estavam morando no estado de S. Paulo no momento anterior a entrada na luta (URUSHIMA, 2000: 35). Porém, conforme verificado posteriormente, os estados de nascimentos aparecem no seguinte proporção: S. Paulo, Minas Gerais e estados da região nordeste. Segundo levantamento do INCRA com 59 famílias, anterior a divisão dos lotes, o tamanho das famílias consistia em: $37,5 \%$ com 1 ou 2 membro; $28 \%$ com 3 ou 4; e, 34\% com 5 ou mais (Cf. URUSHIMA, 2000: 31-2).

As histórias do assentamento a partir de 2001, pelo recorte da configuração espacial dos conflitos sociais, é parte integrante deste trabalho e será vista nos capítulos sobre o trabalho de campo.

\section{Objetivos e método}

Os objetivos da pesquisa fundamentam-se nas seguintes discussões: justiça social (os problemas decorrentes da desigualdade na sociedade moderna), conflitos sociais (as formas como são lidados ou geridos) e a relação entre ciência e ética. Assim, um objetivo, 
num nível macro, é aprofundar discussões sobre campesinato, moradores de rua, conflitos sociais e justiça social. Num nível micro, outro objetivo constitui-se em buscar compreender os conflitos relativos à vida pública, as tensões e as formas de dissolução dos mesmos no interior da comunidade estudada.

O método utilizado no trabalho de campo baseia-se na etnografia, originada nos primórdios da descrição geográfica feita por Ratzel (1990: 94-111) e, distintamente, por Reclus $(1985)^{18}$. Soma-se ao trabalho de descrição, o de interpretação e análise. Nos anos 1970, Lacoste (2003) elogia a postura de cientista e militante de Reclus e faz uma reflexão sobre o comprometimento do pesquisador com o pesquisado. Porém, ao longo do século $\mathrm{XX}$, a etnografia foi apropriada como um domínio da antropologia, que operou importantes sistematizações e reflexões sobre o método.

A etnografia no sentido clássico tem a pretensão de abarcar as múltiplas dimensões da vida do grupo, como a organização familiar, a divisão do trabalho, os costumes, a produção de bens, a religiosidade etc. Porém, a partir da segunda metade do século passado, as formas de etnografia voltaram-se para pontos mais específicos, sem perder o caráter "totalizador" sobre a realidade estudada. Roberto Cardoso de Oliveira (2000: 2933) mostra que, além do clássico e do moderno, há um terceiro tipo de monografia etnográfica proposta pelos antropólogos "pós-modernos" norte-americanos. Mesmo com críticas a este tipo de trabalho, o autor apresenta sua contribuição: enfocar a etnografia como confronto intercultural entre pesquisador e pesquisado. Esta discussão será retomada mais à frente; por enquanto, vale dizer que o presente trabalho prioriza uma etnografia do conflito (Cf. JUSTO, 2002: 26), próximo à linha da etnografia moderna e em diálogo com os questionamentos trazidos pelos "pós-modernos".

Os recursos para a etnografia do conflito compõem-se da presença regular na comunidade, da relação social com os moradores, da observação local das atividades de trabalho e de lazer, da participação nas reuniões e demais atividades coletivas e, principalmente, do estudo de como o grupo produz os espaços público e privado através dos conflitos e também das relações de produção de bens. "Espaço" é sempre tomado no sentido de produto da ação humana.

Também foram utilizadas entrevistas. Com a população oriunda das ruas de S. Paulo, a técnica de entrevista gravada seguiu o padrão de "semi-orientada", conforme

\footnotetext{
${ }^{18}$ Mesmo sem espaço para aprofundar, vale lembrar que Ritter também destaca-se na formulação de métodos descritivos nos primórdios da geografia moderna, conforme observado por Maia (1997: 23-5). Para uma história do pensamento geográfico, ver Moraes (1981).
} 
sistematização feita por Pereira de Queiroz (1991), em que o pesquisado fala mais que o pesquisador, porém este domina indiretamente e orienta o diálogo. Este tipo foi preferido à entrevista rigorosamente orientada, porque interessava ouvir mais o pesquisado ao invés de seguir um padrão direto de pergunta e resposta, em que o entrevistador fala mais do que ouve, e por não se assumir abertamente uma posição de dominação do diálogo. A técnica da entrevista livre também foi preterida porque não se visava fazer uma completa "história de vida" do entrevistado. Apesar deste último tipo possibilitar certo rompimento da dominação do pesquisador, não permite que um dos lados questione o outro. As questões sobre a relação entre técnica de entrevista e posição de dominação do pesquisador são retomadas nas reflexões metodológicas. Por enquanto, vale ressaltar que a entrevista com roteiro, ou semi-orientada, mantém uma dominação, mas permite que as partes se confrontem. Em outras palavras, a "não-diregitividade" e a espontaneidade da entrevista aberta são mais livres e menos dominadoras na relação intersubjetiva, mas não permitem o discordar, mesmo que eventual. Por isso, optou-se pela entrevista com roteiro, semiorientada, e não pela aberta.

Não se objetivava que os entrevistados fizessem reconstruções completas de suas vidas, ao modo de "histórias de vida", por isso optou-se pelo recolhimento de “depoimentos pessoais” (PEREIRA de QUEIROZ, 1991: 60). Segundo Pereira de Queiroz, o trabalho com histórias de vida requer muito tempo e esforço do pesquisador e do pesquisado, portanto, a técnica é normalmente aplicada num número muito pequeno de pesquisados. Como interessava enfocar fatos marcantes na vida do entrevistado, num recorte feito a priori pelo pesquisador - a sua trajetória profissional, o que o levou a morar na rua, o encontro com o MST e os problemas no assentamento -, a coleta de "depoimento pessoal" foi a técnica indicada.

Durante as entrevistas realizadas, baseei-me nas questões expostas logo acima, dando liberdade de tempo de resposta ao entrevistado. As intervenções ocorreram para pedir esclarecimentos de algumas passagens e para recolocar um fio condutor. Eventualmente, permitia-me discordar do entrevistado para procurar entender mais o seu ponto de vista e também porque estava questionando algumas de minhas idéias préestabelecidas. (Em uma das entrevistas, a mais longa, houve a possibilidade de uma troca de pontos de vista.)

Os ex-moradores de rua entrevistados foram: Walter, Ivan, Abelardo, Ademir, Jonas, Jonato, Jandira, Ednardo e Robério. Os nomes ao longo da tese são fíctícios. Das 47 famílias ou indivíduos sozinhos, ficaram quatorze pessoas provenientes das ruas, mas logo 
um veio a falecer. Dentre as treze restantes, um foi internado em manicômio, um abandonou o lote (em 2002) e outro estava no asilo e veio a falecer (em 2004). Um outro recusou-se, num primeiro momento, a ser entrevistado na condição de ex-morador de rua e, em outro contexto, respondeu um questionário. Este caso será tratado posteriormente.

Ao longo do trabalho de campo, procurou-se conversar com quase todos os moradores. A maioria das 47 famílias também foi contatada para entrevistas fechadas (sobre origem, família, parentesco, trajetória profissional e entrada para o MST) ou para colher "depoimentos pessoais" no sentido de reconstruir a trajetória de vida e os conflitos no assentamento, no caso dos ex-coordenadores e diretores do Movimento. Porém, não houve a intenção de cobrir a totalidade dessas pessoas como em relação aos ex-moradores de rua. Com as pessoas envolvidas nos conflitos estudados foram feitas entrevistas “orientadas" sobre o tema. Foi pedido a alguns moradores que desenhassem os sítios para ver as representações que fazem dos mesmos.

Esses métodos ${ }^{19}$ propiciaram a relação com os moradores. Alguns foram receptivos e comunicativos, com outros foi preciso esforço em ouvir seus silêncios até conseguir um depoimento, outros ficaram mais afastados. Ao longo de quatro anos de campo (2001 a 2004), conquistei a confiança de uma grande parcela organizada, mesmo tendo sido, momentaneamente, identificado por alguns como amigo do grupo "oponente". De fato me tornei próximo de um dos primeiros interlocutores, mas deixei claro a todos minha posição e minha intenção de ouvir todas as dissonâncias. Voltaremos a isso no capítulo 4.

Fontes documentais foram consultadas, como os processos de desapropriação e de desenvolvimento do assentamento, atas de assembléias, registros civis de associações, autos processuais etc. Ocorreram entrevistas "orientadas" e conversas com funcionários do INCRA e do Itesp, membros do MST, advogados e membros de redes de apoio aos assentados.

Resta dizer que as idas a campo ocorreram sucessivas vezes ao longo dos anos de 2001 a 2004. Em 2001, fiz os primeiros reconhecimentos do local, das pessoas e realizei algumas entrevistas. Em 2002, entrevistei os ex-moradores de rua. Em 2003, quando defendi o exame de qualificação, estive mais de dez vezes no assentamento e, numa delas, apresentei a alguns moradores o texto do exame. No final de 2004, permaneci três dias no assentamento para complementar os dados e verificar alguns hipóteses de análise.

\footnotetext{
${ }^{19}$ Cabe mencionar que uma parte considerável dos relacionamentos em campo fogem ao registro do método e se dá através de encontros e conversas ao acaso.
} 


\section{Questões e hipóteses}

Apoiado na premissa de que os conflitos sociais são constituintes das relações sociais (Cf. JUSTO, 2000: 41-43) e com base no presente objetivo de aprofundar o estudo sobre conflitos e suas possíveis formas de dissolução presentes no assentamento de Irene, são levantadas algumas questões: Quais são os conflitos e tensões vividos naquele local? Quais são os mecanismos encontrados pela comunidade para a gestão dos conflitos? Há conflitos pelo fato de alguns assentados terem vivido em situação de rua?

Com o trabalho de campo puderam-se verificar as formas de gerir os conflitos, seja com a presença ou não de terceiros, que podem ser os aparelhos do Estado ou militantes da causa da reforma agrária. O estudo de formas para gerir conflitos associa-se à reflexão sobre a construção de espaços horizontais que possibilite uma sociabilidade transparente, igualitária e democrática.

Chama-se a atenção para o livro de D’Incao e Roy (1995), um dos primeiros a tratar de conflitos internos em assentamentos de reforma agrária, que coloca o papel das relações democráticas na superação de comportamentos baseados na dominação ${ }^{20}$. Além desse trabalho, há uma série de teses e dissertações com foco nos conflitos nas comunidades camponesas, principalmente em assentamentos de reforma agrária (MARCOS, 1996; MIRANDA, 1998 e 2003; SIMONETTI, 1999; SCHREINER, 2002; MITIDIERO, 2002). Outros trabalhos, ao estudarem assentamento de reforma agrária, esbarraram em conflitos internos (RAPCHAN, 1993; BARONE, 1996; SIZANOSKI, 1998; FERNANDES, 1996 e 1999; CARVALHO, 1998 e 1999; SOUZA, 1999; MARQUES, 2000; PEREIRA, 2000; NARITA, 2000; IHA, 2001; ALMEIDA, 2003; FELICIANO, 2003; FABRINI, 2003; GONÇALVES, 2004).

A partir disso, foram traçadas duas hipóteses comprovadas ao longo da tese:

1) A mudança para o campo é uma "alternativa" para um problema vivido na cidade, a condição de morador de rua. A tese procura verificar, no capítulo seis, de que maneira a "alternativa" pode se realizar. Mas, de qual "alternativa" está se falando? É a alternativa ao mundo do emprego, ao modo de produção capitalista. Quer dizer, não é possível colocar a questão do morador de rua como mera exclusão do mercado de trabalho.

\footnotetext{
${ }^{20}$ No entanto, o pressuposto dos autores (D'INCAO e ROY, 1995) de que os assentados trariam em sua formação relações de dominação e, conseqüentemente, as reproduzem vai de encontro com a premissa aqui assumida de que a luta pela terra ocorre devido a elementos culturais anti-autoritários. Outro ponto de diálogo com o referido trabalho diz respeito às formas do pesquisador intervir nas relações entre os assentados. Portanto, são duas críticas ao trabalho seminal de D'Incao e Roy (1995) a serem retomadas; ver capítulo três.
} 
O diapasão das “alternativas" apresenta várias notas. Uma delas é, justamente, a da falta de alternativas. Num sentido, para uma grande parte das pessoas que estão vivendo nas ruas não há alternativa para sair dessa situação: todas as portas fecham-se para quem está nas ruas (não há vagas para trabalho; familiares, amigos e vizinhos “somem”), resta sofrer as ações assistencialistas e a caridade dos transeuntes. Junto a essa situação, há pessoas que estão por anos nas ruas e a inexistência de alternativa confunde-se com uma possível falta de vontade, ou de ânimo, para mudar de situação. A idéia de Dowbor de que “a partir de um certo nível de destituição, os pobres perdem a autonomia de autoconstrução do seu espaço na sociedade (...)", usada para descrever a "dura realidade nordestina", pode ser extrapolada para situação mais dramática da vida nas ruas (DOWBOR, 2000: 15).

Porém, o morar nas ruas também constitui-se num direito ${ }^{21}$ e certas condições devem ser garantidas para tal. Este aspecto legal é importante porque não se trata de enfocar a situação de rua somente como "falta de alternativa", morar na rua também é uma “opção”. A situação ideal é o Estado garantir àqueles que vivem nas ruas a possibilidade de optar por continuar nessa situação, tendo os serviços básicos, ou apresentar saídas dignas.

Há aqueles que agarram a primeira nota que lhes soa como saída e entram, espontaneamente, para a luta por um pedaço de terra, via MST. Almeida, na sua experiência com meninos de rua de Maceió/AL, narrou que alguns deles entraram para o Movimento após conhecerem um acampamento na cidade (ALMEIDA, 2001: 225-9). Destaca-se o espontâneo dessa ida para acampamento, descrita pela autora, porque não resultou da ação de militantes do MST junto à população de rua.

Do diapasão de alternativas, a hipótese tratada afina-se com a idéia da economia solidária, trabalhada por Singer (1998 e 2001). Para o autor, a economia solidária é uma alternativa não-capitalista ao desemprego mundial das últimas décadas, provocado pela revolução industrial da microeletrônica e pelo neoliberalismo, porque se contrapõe ao modo de produção capitalista e porque não gera empregos e sim ocupações autogestionárias e prioriza a solidariedade ao invés da competição, como base de um novo modo de produção (SINGER, 1998; 118-139) 22 .

\footnotetext{
${ }^{21}$ Em 1997 foi aprovada lei municipal, No. 12.316, que estabelece como dever do poder público municipal da cidade de São Paulo manter serviços e programas de atenção à população de rua garantindo "padrões éticos de dignidade".

${ }^{22}$ Vale ressaltar que Singer (2002a, 2002b) estabelece o cooperativismo autêntico como um dos elementos centrais da economia solidária, desse modo as cooperativas de produção agropecuária organizadas pela MST em assentamentos estão nesta proposta socialista. O elemento de ver nas cooperativas o principal componente do modo de produção socialista já estava presente em Chayanov (1974 [1925]: 317-8).

A Secretaria Nacional de Economia Solidária, órgão do Ministério do Trabalho, define este tipo de economia da seguinte forma: "A economia solidária corresponde ao conjunto de atividades econômicas - de produção,
} 
A alternativa da economia solidária ressoa, num certo sentido, a proposta de etnodesenvolvimento defendida por Stavenhagen (1985). O sociólogo mexicano faz uma revisão das teorias desenvolvimentistas para mostrar suas limitações e propõe um "desenvolvimento alternativo", no seguinte sentido: 1) suprir necessidades básicas de um grande número de pessoas, ao invés do crescimento econômico por si mesmo; 2) voltar-se para uma visão interna e não externa, exportadora; 3) aproveitar as tradições culturais e não tomá-las como obstáculos; 4) respeitar a ecologia; 5) usar os recursos locais, orientando-se para a auto-sustentação local, regional e nacional; 6) ser mais participante do que tecnocrático (STAVENHAGEN, 1985: 18-9). A esses tópicos, o autor incorpora a discussão sobre etnicidade e estabelece como principal questão contemporânea o etnodesenvolvimento, o desenvolvimento de grupos étnicos no interior de sociedades mais amplas. Importante ressaltar que essa reflexão critica a teoria do desenvolvimento agrícola por ter considerado os camponeses extintos e mostra que com as crises de alimento da década de 1970 esse grupo social foi redescoberto. Assim, os teóricos do desenvolvimentismo passaram a incorporar a economia das unidades domésticas camponesas no sentido de aumentar sua produtividade. No entanto, o etnodesenvolvimento toma como base fundamental dos sistemas econômicos e sociais as unidades domésticas.

Ao tratar do ritmo de transformar morador de rua em camponês, vale refletir sobre o papel desta classe social no desenvolvimento do país. Como mostrou Oliveira (1997), não cabe mais compreender o campesinato pelo veio do desenvolvimento das forças produtivas em direção a um capitalismo mais avançado, o velho debate capitalismo versus feudalismo, mas sim pelo posicionamento socialismo contra capitalismo. "Nosso papel, nesse particular, constitui-se em ver e ouvir. Pois já é hora de entendermos que são os trabalhadores - os maiores interessados na transformação da sociedade - que devem falar. A nós cabe entender" (OLIVEIRA, 1997: 22).

Em sintonia com esses autores, considero o presente trabalho uma continuidade da proposição de Oliveira sobre socialismo versus capitalismo. Assim, nessa hipótese de ir para o campo como alternativa para o morador de rua está em jogo a inserção de uma parcela da população na construção de um modo de vida e de produção outro do capitalismo. Em certa medida, os moradores de rua por não estarem empregados já são

distribuição, consumo, poupança e crédito - organizadas sob a forma de autogestão, isto é, pela propriedade coletiva dos meios de produção de bens ou prestação de serviços e pela participação democrática (uma cabeça, um voto) nas decisões dos membros da organização ou empreendimento" (MINISTÉRIO DO TRABALHO/Senaes, 2005: 5). 
Outro do modo de produção capitalista. Ao longo do texto, mostram-se os avanços e as limitações na realização desse caminho.

Da primeira hipótese, decorrem outras perguntas que norteiam a pesquisa: o que leva um morador de rua a entrar para o MST? Qual é a disposição daqueles em comparação com os demais para trabalhos coletivos? O ethos camponês é uma essência ou algo que pode ser construído? Estas questões são respondidas no quinto capítulo.

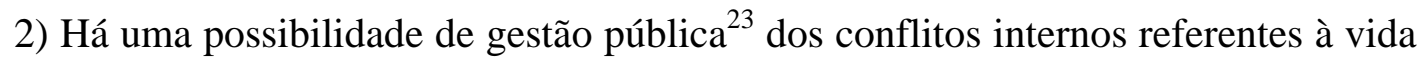
coletiva que pode ser desenvolvida no assentamento. As perguntas decorrentes são: como ocorre a gestão pública?; quais são os meios de aprendizado dessa forma coletiva de gerir os conflitos?; qual é o papel do pesquisador neste sentido? Mais uma pergunta persiste: qual a capacidade dos assentados e, principalmente daqueles que vieram das ruas de formar, manter e ampliar redes de alianças? Esta desdobra-se na seguinte: como se tecem redes sociais com laços fortes?

Cabe explicar a distinção entre a gestão pública dos conflitos e a estatal, uma vez que o Estado é a instância pública por excelência. Porém, a gestão estatal dos conflitos não é realizada pelo público envolvido, mas por técnicos operadores da lei e, portanto, distantes do cotidiano gerador do conflito. Além disso, o controle social exercido pelas leis baseia-se em distinções sociais, conforme estabelecido pela teoria de Black (1998).

A gestão pública dos conflitos diz respeito ao controle social e à apropriação do espaço exercido pela população de um dado local, no caso um assentamento de reforma agrária. É este movimento que transforma o espaço em território, no sentido definido por Raffestin (1993). Essa forma de gestão não nega os poderes estatais. No entanto, a gestão pública, ou "gestão democrática”, baseia-se na concepção colocada por Quijano (2002), que estabelece um "sistema de controle democrático da autoridade" referenciado em instâncias supranacionais (QUIJANO, 2002: 511-2). Essas questões serão desenvolvidas nos capítulos três e seis.

As duas hipóteses são questões sobre o espaço. Como tratado a seguir, a ciência define-se pelas questões colocadas; logo, as questões sobre o movimento da cidade para o campo e sobre a constituição do espaço público são eminentemente geográficas.

\footnotetext{
${ }^{23}$ Há um paralelo entre "gestão pública" e "gestão democrática" se a democracia for tomada no sentido dado por Quijano (2002: 511-2), como se verá no capítulo três. Sobre "gestão democrática" e "autogestão" em
} 


\section{Reflexões sobre metodologia}

Três recortes metodológicos percorrem essa reflexão:

1) Relações de poder entre pesquisador e pesquisado e acesso ao Outro;

2) O caráter definidor da ciência geográfica e a ética;

3) A relação entre ciência e justiça social.

Os três recortes amarram-se na seguinte questão: fazer ciência como, por quê e para quem?

\section{1) Relações de poder entre pesquisador e pesquisado e acesso ao Outro}

As reflexões metodológicas apresentadas são resultado de duas inquietações, uma decorrente da experiência de trabalho de campo e outra das leituras sobre metodologia. A primeira inquietação diz respeito ao seguinte: qual é o direito ou a legitimidade do pesquisador adentrar na vida do grupo estudado? A segunda volta-se para a longa discussão fundamental nas ciências humanas: qual a possibilidade de acesso ao Outro?

A autoridade da ciência permite que o cientista "invada" o território do seu objeto de estudo. Porém, o que reverte para a comunidade pesquisada do resultado do conhecimento científico? Por que o cientista pode adentrar a casa, descrever a alimentação e fazer perguntas sobre a privacidade do pesquisado? Por que o tempo do pesquisado pode ser tomado se os interesses diretos dele não estão envolvidos na pesquisa? É desconfortante a sensação de "invadir" a vida dos entrevistados, por exemplo, pelo pretexto nobre da produção científica. Sabemos, no entanto, que o pesquisado abre sua privacidade conforme seus interesses e possibilidades. Sem pretender reinventar a roda, o ponto de fuga, novamente, é a produção conjunta do conhecimento, o diálogo e as negociações entre pesquisador e pesquisado.

O poder da ciência de produzir verdade, personificado no pesquisador, tem tanto o caráter de controle social quanto o de gerar poder ao pesquisado ${ }^{24}$. Colocar um sujeito em estudo, dar evidência a um ser específico através de um discurso científico, é dar existência ao mesmo como um problema para o conhecimento. É como objeto do saber científico que os diferentes seres humanos constituem-se como sujeitos, como nos ensinou Foucault (ver item 2, a seguir). A obra de Foucault permite pensar a relação pesquisador pesquisado 
somente pelo prisma da constituição desse sujeito criado pelo poder. No entanto, o ponto de partida deste trabalho é o de que há uma ambivalência no tratamento de um objeto de pesquisa: uma dimensão é a do controle social e outra é a de dar poder ao sujeito estudado. Por um lado, construir uma interpretação sobre um ator social é, também, mostrar suas práticas e concepções. Neste sentido, pode haver controle social do pesquisador sobre o pesquisado, pois aquele pode expor (às vezes, em demasia) este último. Por outro lado, o pesquisador pode contribuir para gerar poder ao sujeito estudado, colocando-se como um agente catalisador dos potenciais inovadores de determinadas ações deste. Vale ressaltar que, neste segundo sentido da relação de poder, o pesquisado também exerce poder e controle sobre o que (e como) será revelado ao pesquisador. Para fundamentar esse segundo registro, é preciso buscar outros autores além de Foucault.

Posto isso, a presente reflexão dialoga, principalmente, com autores como Clifford Geertz (e a possibilidade de se interpretar as culturas através dos termos nativos), Vicent Crapanzano (e a relação de poder no diálogo entre pesquisador e pesquisado), Roberto Cardoso de Oliveira (e seu balanço crítico sobre a metodologia das ciências humanas) e Paulo Freire (e a construção compartilhada do conhecimento), para assumir muito dessas perspectivas. Assim é possível conectar a relação de poder entre pesquisador e pesquisado com a questão do acesso ao Outro e apaziguar as inquietações.

O Outro é algo impossível de ser acessado ou a etnografia é um instrumento fiel de estabelecer a relação entre nós e os outros? Esta questão aparece, para não se cair num século de debates, em autores como Merleau-Ponty e Foucault, para nos restringirmos à forma que ela assume na segunda metade do século $\mathrm{XX}^{25}$. O Outro pode ser lido como um texto ou estamos sempre falando de nós mesmos quando acreditamos o estar descrevendo? Os trabalhos de Geertz $(1989 ; 1983)$ propiciam certas garantias de interpretação da cultura do Outro, através do uso dos termos nativos. Esse autor mostra como as questões de acesso

\footnotetext{
${ }^{24}$ Discussão semelhante aparece em Clifford (1986: 118), porém não exatamente com o mesmo teor. A minha questão sobre o poder do pesquisador está mais próxima daquilo que Capranzano trata em "Diálogo" (1991).

${ }^{25}$ Ver o texto de M. Merleau-Ponty, "De Mauss a Levi-Strauss" (1984) e, principalmente, a nota da tradutora e organizadora, M. Chauí (nota 8, p. 199-200), apresentando as proximidades e diferenças entre o pensamento de Merleau-Ponty e o de Foucault. Grosso modo, a questão central é a possibilidade de encontro do Outro, ou seja, até que ponto o pesquisador consegue, de fato, apreender o pesquisado. Para o primeiro, a etnologia possibilita esse encontro e para Foucault seria simplesmente impossível tal encontro.

Vale contrapor a leitura que Marilena Chauí faz da obra de Foucault e a de Didier Eribon (1990). Este mostra, através de artigos jornalísticos escritos por Foucault, como o filósofo francês - ao visitar o Irã - traz para sua reflexão a relação entre o dito mundo moderno e o outro, o Oriental muçulmano. O registro foucaultiano, independentemente da busca de apreender o outro, o traz como contraponto ao mundo moderno.
} 
ao Outro e do relativismo aumentam de complexidade a partir das críticas ao conhecimento científico feitas por autores como Foucault (GEERTZ, 1983: 151).

A posição de Geertz (1983: 55-70) aponta um modo para decifrar o Outro: ler a cultura como um texto, utilizando os termos do nativo. $\mathrm{O}$ autor, que é tido como inspirador dos críticos "pós-modernos", procura uma saída para a questão epistemológica de como o conhecimento antropológico do modo como os nativos pensam, sentem e percebem é possível. Ele diz que para interpretar ou entender o sentido do Outro é preciso conhecer seu sistema simbólico, então, entender a vida do nativo é como ler um poema. Não é necessário que o pesquisador seja uma pessoa que pertença ao grupo estudado. Há uma desigualdade entre os termos do informante e os do pesquisador que não é polar e sim de grau. É preciso entender o que eles pensam que são, o etnógrafo percebe através dos termos nativos. Isto é, o etnógrafo não percebe aquilo que o nativo percebe, ele pode interpretar "com" ou "através" dos termos colocados por este último.

Porém, como menciona Marcus $(1993)^{26}$, Geertz não estaria preocupado com as relações de poder envolvidas na pesquisa. Clifford (1998: 227-251), por sua vez, critica Geertz por construir uma espécie de "tipo ideal" da cultura dos outros. Ou seja, como os dados de campo são tratados "como texto", Geertz não levaria mais em consideração com quem e em quais condições os mesmos foram colhidos. Mostra também que, por exemplo, muito do trabalho etnográfico foi produzido pelos próprios nativos e isto sugere que estes são co-autores do trabalho ${ }^{27}$. Vale destacar que há uma forma de interpretar o sentido do Outro, que se contrapõe a Geertz, em Augé (1999) que aprofunda a proposta de interpretação proposta por aquele autor.

A realização de co-autoria propicia uma relação mais horizontal entre pesquisador e pesquisado. Porém, implica que aquele esteja despido de objetivos a priori para que este imprima sua autoria. Como na presente tese os objetivos foram colocados pelo pesquisador, não se trata de uma co-autoria. Está mais próxima de um diálogo. Por exemplo, um interlocutor no meu trabalho de campo cobrou que não fossem revelados publicamente certos desdobramentos de alguns conflitos vividos no assentamento. Também pediu que um determinado morador não fosse entrevistado porque me receberia

\footnotetext{
${ }^{26}$ Marcus (1993) e uma série de antropólogos norte-americanos passaram a atacar, a partir da década de 1980, certo autoritarismo presente nas etnografias modernas. Para um apanhado geral das questões levantadas por aqueles autores, ver Clifford e Marcus (1986). Autores brasileiros entraram no debate (CALDEIRA, 1988; PEIRANO, 1992; DaMATTA, 1992; OLIVEIRA, R. C., 2000), aceitaram certas críticas sobre o autoritarismo do pesquisador, mas procuraram a possibilidade de explicação antropológica que teria sido descartada por alguns dos norte-americanos "pós-modernos".

${ }^{27}$ Para uma crítica da noção de co-autoria proposta por Clifford, ver O’Hanlon e Washbrook (2000: 210).
} 
mal, pois desconfiava de um possível uso indevido da entrevista. Ao aceitar parcialmente esses pedidos e cobranças, compartilhei com ele alguns rumos do trabalho e reconheci seu poder de intermediar as relações entre outros assentados e mim. Com base nessas questões metodológicas, procurei também negociar "a realidade" com ele, sabendo - como mostrou Crapanzano - que havia uma disputa sobre a forma de se apropriar do discurso (CRAPANZANO, 1991: 68). Vale o ensinamento deste autor: "Há que lembrar que qualquer que seja a resistência daqueles com quem conversamos, eles sempre são um pouco nossa criação, assim como nós somos a deles. Esse fato empírico talvez marque o limite de nosso empiricismo" (CRAPANZANO, 1991: 79).

Voltando ao debate, Roberto Cardoso de Oliveira (2000:17-35) realiza a passagem entre Geertz e os chamados "pós-modernos" norte-americanos. Quanto às denúncias do poder exercido pelo pesquisador ao ouvir o "informante", o autor coloca que enquanto o pesquisado for um "informante" não há diálogo possível, mas quando é colocado como "interlocutor" um novo relacionamento toma lugar.

Oliveira baseia-se no trabalho de Geertz para refletir sobre a elaboração dos trabalhos acadêmicos de cunho etnográfico. O ponto é a separação entre aquilo que se viu e se ouviu quando se esteve "lá", no campo, e a forma de se escrever, quando se encontra "aqui", no gabinete. Ele chama a atenção para o fato de as "monografias experimentais", ou "pós-modernas", ao denunciarem a pretensão de objetividade através do ocultamento do narrador do texto das etnografias modernas, caíram num intimismo excessivo da narrativa em primeira pessoa. Esse intimismo seria contrário a um texto polifônico, que permitiria muitas vozes e não isentaria o autor da responsabilidade com o discurso de sua disciplina. Neste caso, conclui o autor, o texto pode preservar o "confronto intercultural" entre pesquisador e pesquisado, numa atitude relativista.

Outro aspecto que Oliveira chama a atenção, em continuidade com o exposto acima, é a convivência entre os paradigmas antropológicos e a incorporação das críticas levantadas pela hermenêutica. Haveria quatro paradigmas na antropologia, o racionalista, o estrutural-funcionalista, o culturalista e o hermenêutico, que não cabe aqui serem explicados, mas deve-se salientar que os três primeiros estão conectados aos princípios do Iluminismo, enquanto o quarto representa a reação a este modelo de razão. Então, vale enfatizar as contribuições da hermenêutica: a moderação da autoridade do autor eliminando o autoritarismo, a maior atenção na elaboração do texto, a preocupação com o momento histórico do encontro etnográfico e uma compreensão dos limites da razão científica, mas ainda acreditando no projeto racional moderno (OLIVEIRA, R. C., 2000: 
53-72). A grande lição dada pelo autor é: para se compreender o Outro, este deve ser estimulado a nos compreender; amplia-se assim o escopo da pesquisa ao se promover uma fusão de horizontes, em que o pesquisador abre espaço para o ponto de vista do outro sem abdicar do seu.

Respeitando as delimitações metodológicas de cada autor, é possível encontrar pontos semelhantes entre as posições expostas de Geertz e de Oliveira com as de Freire. O resgate das idéias de Freire $(1992 ; 2001)$ deve-se à relação que ele estabelece entre ciência, ética e política. $\mathrm{O}$ registro de suas idéias é pedagógico e epistemológico. O ponto central de seu trabalho é: o conhecimento só ocorre quando o educador aprende com o educando e, ao transformar o educando, também transforma-se. Para isso, os dois têm de ser diferentes, pois se fossem iguais não haveria o que aprender um com o outro. Porém, a diferença não quer dizer desigualdade. Ao contrário, os dois lados devem estar no mesmo plano, os dois possuem conhecimentos distintos e os dois querem ter outros conhecimentos. Assim, diz o autor que o respeito a posições antagônicas entre educador e educando é uma prática democrática. Na relação entre educador e educando, ou entre pesquisador e pesquisado, o primeiro precisa conhecer a cultura do segundo para falar “com" ele e não falar "para" ele, ensina o autor. Sem querer simplificar a complexidade da obra de Freire, o que se assume nesta tese são essas idéias centrais do autor. Porém, não se assume no trabalho de campo uma postura de educador, no sentido dado por Freire, porque não houve esse interesse por parte dos pesquisados e nem o pesquisador tinha tal objetivo. Provavelmente o pesquisador esteve em campo mais como um educando, querendo aprender com o Outro formas de lutar por justiça social e de lidar com os conflitos.

Para retomar a centralidade dessa reflexão metodológica, vale exemplificar. Ao procurar as pessoas por serem ex-moradores de rua acabei, sem querer, por reforçar um estigma (negativo), ao qual eles se viram no papel de rejeitar. Dois entrevistados fizeram questão de justificar que ficaram nas ruas por falta de outras condições, mas que não eram "vagabundos como os outros"; disseram que não tinham vergonha de assumir que moraram nas ruas, mas colocaram como algo provisório. Um desses dois, repetidas vezes, enfatizou que na rua tem pessoas trabalhadoras como ele e os "vagabundos e bêbados", que são os outros. Outro morador do assentamento que veio das ruas teria se negado a conceder a entrevista, uma vez que eu o procurava como morador de rua, segundo aqueles outros dois haviam me informado. Reconheci seu objetivo de rejeitar o estigma e sei que não daria para lhe mostrar que havia uma valorização minha em enfocar a luta do morador de rua. Esperei consolidar minha presença no assentamento para procurar esse homem. 
Enfim, são negociações que acontecem no trabalho de campo ${ }^{28}$. O pesquisador tem seus objetivos pré-estabelecidos: a pesquisa (objetivos, questões, hipótese, metodologia) e seus resultados. Por este aspecto, não estaria fazendo "pesquisa participante" ou "pesquisaação", no sentido de que a comunidade se torna a pesquisadora de si mesma - colocando o tema e os objetivos - e o pesquisador, um catalisador; mas, mesmo assim, este posicionamento científico é uma das referências ${ }^{29}$. O pesquisador também carrega seus valores, como o de justiça social. Por isso, a minha intenção é de "positivação" de uma condição social tida como "negativa" e do ato de superação da mesma. Portanto, não haveria porque dissimular que estava ali para entrevistar ex-moradores de rua (não daria também para querer "convencer" aquele que, inicialmente, recusou a entrevista de que ter sido morador de rua é importante para mim). O pesquisado é sujeito, mas não deve estar "assujeitado" aos interesses do pesquisador. É nesse "entre-lugar" da negociação que se produz conhecimento. Essa "valorização" defendida (e Harvey [1996: 11] chama a atenção para os processos de valoração, ao invés da centralidade da questão do valor) é colocar o extremo da marginalização (sem-teto, sem-trabalho, sem-terra etc) no centro. A partir desse centro, indagar o que é a sociedade, que precisa ser explicada, e a natureza, que não é una. A perspectiva do pesquisador situar-se no centro da moderna polarização entre sociedade e natureza baseia-se nos trabalho de Latour (2000a; 2000b), a ser visto no próximo item.

\section{2) O caráter definidor da ciência geográfica e a ética}

O que define o campo específico de uma ciência? Muitos autores vão defender que é o objeto de estudo, outros dirão que são os conceitos utilizados e alguns mostrarão que é o olhar. No entanto, Horário Capel Saez estabelece, embasado em Toulmin, que os domínios das disciplinas não devem ser identificados pelos tipos de objetos, mas pelas questões propostas ao objeto, porque este pode estar sob o domínio de diversas ciências (CAPEL SAEZ, 1999 [1977]: 13). Capel percorre o árido caminho das investigações sobre o desenvolvimento do conhecimento científico e mostra que, a partir de 1930, o mesmo bifurca-se em um caminho interno - o desenvolvimento científico como resultado de um

\footnotetext{
${ }^{28}$ Uma das referências é o texto de Schmidt (2003), que enfatiza a necessidade do pesquisador realizar seu trabalho em conjunto com o pesquisador, a outra é Castro Oliveira (1998: 7), quando coloca a reciprocidade como princípio para o trabalho etnográfico.

${ }^{29}$ Sobre definições e métodos da pesquisa participante, ver Brandão [Org.] (1999a) e Castro Oliveira (1998: 7). Sobre as referências que auxiliam as reflexões metodológicas desta tese, ver Brandão [Org.] (1999b).
} 
debate intelectual que refina teoria e faz surgir novos problemas científicos - e outro externo - o peso dos fatores sociais na produção e desenvolvimento do conhecimento. A partir do trabalho de Khun $(1996[1962])^{30}$ e, mais especificamente, nos anos 1970, a bifurcação entre os aspectos internos e externos se funde. Surgem correntes que estudam a existência de disciplinas científicas (aspecto interno) como inseparável das comunidades científicas (aspecto externo). Esse é o posicionamento de Capel: o desenvolvimento do conhecimento científico e a multiplicação das disciplinas "estão relacionados com a existência de comunidades científicas bem estruturadas e com fortes apoios institucionais" (CAPEL SAEZ, 1999: 13). Portanto, é com base na relação com as comunidades científicas que se pode entender as mudanças conceituais e a criação de disciplinas científicas. Em decorrência, as disciplinas devem ser definidas pelas questões propostas ao objeto, como um empreendimento intelectual de uma comunidade específica.

Do texto do geógrafo espanhol, importa também a definição sintética de ciência como sendo um conhecimento racional, institucionalizado e reconhecido pela comunidade científica. Sendo assim, há uma disputa por prestígio e poder dentro das distintas comunidades científicas (CAPEL SAEZ, 1999: 19-20).

Por enquanto, interessa a definição de domínio científico dada pelas questões feitas e não pelo objeto de estudo. Tal definição coloca as hipóteses desta tese no registro geográfico, pois tratam de temas eminentemente espaciais: o movimento da cidade para o campo e a formação de uma esfera pública num assentamento. Serve também para assumir um distanciamento em relação aos trabalhos de geografia sobre assentamento de reforma agrária que tendem a definir o campo de estudo pelo objeto e/ou pelo conceito de território, conforme será visto no capítulo dois.

Posto isso, há duas observações. Primeira, a geografia - a partir da década de 1970 - assume um enfoque na questão do poder. Mais especificamente, veremos os trabalhos de Lacoste e Raffestin, que - mesmo sendo contemporâneos da publicação original do texto referido de Capel - não definem a geografia pelas questões, mas pelo objeto e/ou pelos conceitos. Segunda, a forma de estudo do desenvolvimento do conhecimento científico passou por uma reviravolta no final dos anos 1990, com trabalho de autores como Latour.

As elaborações presentes nas duas seleções de textos organizadas por Brandão guardam uma simetria temática e histórica com as dos antropólogos "pós-modernos" dos EUA, apesar de metodologicamente distintas. Ou seja, há um paralelo entre a "pesquisa ação", de Brandão, e "co-autoria", de Clifford.

${ }^{30}$ Para Khun (1996), o desenvolvimento do conhecimento científico ocorre por revoluções (mudanças na visão de mundo) nos paradigmas. Um paradigma baseia-se no desenrolar da "ciência normal", que consiste em pesquisa baseada em conquistas científicas passadas, conquistas reconhecidas por uma comunidade científica por um período de tempo como suporte das práticas futuras. 
Um dos primeiros autores a chamar a atenção para a relação entre espaço e poder foi Yves Lacoste, em A Geografia - isso serve, em primeiro lugar, para fazer a guerra, publicado originalmente em 1976. A contribuição do texto está em mostrar que a institucionalização acadêmica da geografia, relativamente recente - a partir do século XIX -, deixou de lado o cerne desta disciplina: a noção de que ela serve, antes de tudo, para o poder de Estado. Os conhecimentos estratégico e bélico presentes nos mapas e na questão de escala continuaram na mão do Estado, enquanto a geografia acadêmica ficou com os aspectos "simplórios e enfadonhos" sobre clima, relevo, população, agricultura etc. Neste sentido, o autor refere-se a uma geografia dos professores e outra dos oficiais. Então, ele reivindica para a geografia a re-apropriação do lado estratégico do conhecimento sobre espaço e território, que pode ser usado também para explicar ataques bélicos ${ }^{31}$. Assim, para o geógrafo marroquino o fundamental é que a articulação dos conhecimentos relativos ao espaço é um poder, um saber estratégico. Mesmo voltado para uma visão de ciência definida pelo objeto, ele mostra o quão fundamentais são as "questões" levantadas pela geografia sobre as diferentes ordens de grandeza, que implicam diferentes níveis de análise e que revelam realidades distintas (LACOSTE, 2003: 90).

Relacionado às indagações presentes nestas reflexões metodológicas, o livro de Lacoste contribui para mostrar que os estudos geográficos fornecem informações ao poder que permitem agir sobre as populações habitantes dos locais estudados. Portanto, relaciona pesquisa e ética de modo que o geógrafo deve perguntar-se sobre os usos posteriores dos resultados de seu trabalho e, se for o caso, recusar sua divulgação se houver o risco de espoliação da população estudada. Ou, caberia ao pesquisador encontrar meios para que essa população disponha do saber estratégico a fim de melhor organizar-se e defender-se. As pessoas devem saber o porquê das pesquisas de que são "objeto" (LACOSTE, 2003: 171-9). Neste sentido, o autor resgata a postura ética de pesquisador e militante de Reclus $^{32}$.

Essa relação ciência e ética vai ao encontro das questões metodológicas aqui tratadas. No entanto, a concepção de poder trabalhada por Lacoste é limitada. O poder é concebido de forma abstrata, sempre como terceiro elemento de uma relação e que só diz respeito ao Estado ou à empresa. Com esta visão sobre o poder, ele contrapõe-se à

\footnotetext{
${ }^{31}$ Em um de seus trabalhos, Lacoste explica a estratégia dos EUA em bombardear os diques que protegiam as planícies densamente povoadas do, então, Vietnã do Norte, em 1972 (LACOSTE, 2003: 27).

32 Contemporaneamente, um exemplo de trabalho em geografia agrária voltado para um comprometimento ético com o pesquisado é o texto de Bombardi (2003).
} 
geografia de Raffestin, que coloca o poder no plano das relações inter-pessoais (LACOSTE, 2003: 243).

Para esta tese, a posição expressa em Por uma Geografia do Poder, de Claude Raffestin (1993 [1980]), representa um avanço em relação a de Lacoste ${ }^{33}$. Ao incorporar a definição de biopoder, de Foucault, a geografia do poder pode trabalhar a relação pesquisador pesquisado além do registro de algo que servirá para o Estado.

Raffestin (1993) faz a crítica da geografia política clássica de Ratzel, entre outros, para se contrapor à noção de que o poder refere-se exclusivamente ao Estado. Com base no princípio de que a verdadeira geografia só pode ser uma análise dos poderes, segue a definição foucaultiana de poder: 1) algo que não se adquire e é exercido a partir de inúmeros pontos; 2) é imanente a todas as relações; 3) vem de baixo e não há oposição entre dominante e dominado; 4) tem intencionalidade e não subjetividade; 5) onde há poder há resistência e esta não é exterior àquele ${ }^{34}$. A partir disso, o autor coloca que o poder não é influência nem autoridade e que, portanto, está ligado à manipulação dos fluxos de energia e informação, como duas variáveis inversamente proporcionais. Assim, população, território e recursos são trunfos do poder.

Para Raffestin, “território" é um conceito que se diferencia da noção de espaço. Aquele é resultado da ação de um ator social que quando se apropria de um espaço, o territorializa. Porém, o conceito de território não é suficiente sem o de rede, que o complementa. Junto ao território, nos lugares do poder há nodosidade, centralidade e marginalidade. Ou seja, há lugares que apresentam densidades mais fortes ou mais fracas de relações, como aspecto das redes. Segundo Raffestin, do território surgem tessitura, nó e rede; portanto, deve-se levar em conta este conjunto de superfícies, pontos e linhas. Podemos nos apoiar nesse geógrafo para colocar um assentamento de reforma agrária como sendo um território (dentro de outro maior) em que os lotes são nós (pontos) e as redes são as linhas que unem os pontos, ligando fragmentos (gastando energia e informação) e, assim, compondo tessituras.

Quanto às redes, em que nodosidade, centralidade e marginalidade estão implicados, interessa que tanto na circulação quanta na comunicação - processos simultâneos - os atores sociais confrontam-se com elas. Para o autor, as redes são móveis e

\footnotetext{
${ }^{33}$ Dentro do mesmo contexto espaço-temporal de Lacoste e Raffestin, há o livro de Paul Claval, Espaço e Poder [1979], que trabalha com a noção de geometrias do poder. O texto de Claval não será trabalhado aqui porque, apesar de se utilizar de Foucault, não explora o potencial da noção de biopoder como faz Raffestin (1993). Este autor reconhece a importância do livro de Claval. Para um exemplo da aplicação da análise de Claval, ver Justo (2002).
} 
inacabadas e por isso têm a força de adaptar-se ao espaço e ao tempo. O geógrafo francês embasa-se na seguinte definição dada por M. Serres: “A rede faz e desfaz as prisões do espaço, tornando território: tanto libera como aprisiona. É o porquê de ela ser o 'instrumento' por excelência do poder" (Michel Serres, Hermes ou la Communication, apud RAFFESTIN, 1993: 204) ${ }^{35}$.

Tanto o conceito de território quanto o de rede serão trabalhados ao longo desta tese, principalmente no debate com os outros trabalhos de geografia sobre assentamentos de reforma agrária no capítulo três. A noção de rede será aprofundada ao final deste tópico com os textos de Latour.

Retomando a discussão sobre o desenvolvimento do conhecimento científico, a contribuição da obra de Foucault (1983, 1988, 1993a e b) é relevante porque coloca um novo enfoque sobre a episteme ao esmiuçar a relação entre verdade e poder. Para ele, a "verdade" é um conjunto de procedimentos para a produção e circulação dos enunciados (científicos); portanto, há um "regime" da verdade na base de formação e de desenvolvimento do capitalismo. A questão política para o intelectual é desvincular o poder da verdade das formas hegemônicas atuais (FOUCAULT, 1993a: 14). Uma questão central para o autor é como os seres humanos são construídos como sujeitos através de distintos dispositivos de assujeitamento. Por isso, ele dedica-se a uma nova análise das relações de poder; o poder como criador de sujeitos. Assim, a concepção foucaultiana serve para alertar o pesquisador sobre a relação entre verdade e poder.

Dadas essas observações, o papel do pesquisador em campo é o de aprender com os sujeitos práticas que sejam emancipatórias, como será tratado por Santos (2002).

Uma nova maneira de realizar estudos sobre o modo como a ciência é feita ocorre, em 1987, com a publicação de Ciência em Ação, de Bruno Latour (2000a). A contribuição do autor para esta tese é de trazer uma teoria para a relação ciência, técnica e sociedade centrada nas "redes". A ciência, ao tentar explicar fenômenos (clonagem, transgênicos, por exemplo), cria caixas-pretas, ela caminha por sucessões destas e, portanto, não trata de essências e sim de redes que mantêm ou refutam as caixas-pretas. Através de controvérsias, a ciência caminha e a explicação científica válida é aquela que mobiliza a maior rede com nós mais fortes. O autor coloca a noção de "rede" como melhor do que a

\footnotetext{
${ }^{34}$ Ver Foucault (1988: 88-97).

${ }^{35}$ Os trabalhos de Haesbaert da Costa (1995a e b) são exemplos recentes do uso simultâneo dos conceitos de território e de rede. Mostra que a territorialidade em certa medida cria solidariedade, mas em excesso mata esta possibilidade. Portanto, deveria haver convivência entre território e rede. O autor coloca como opostos
} 
de "sistema", a de "estrutura" e a de "complexidade". Assim como Raffestin, Latour retira a noção de rede dos trabalhos do filósofo francês Michel Serres, entre outros autores. "Rede" é a capacidade de conectar e de separar, de produzir espaço e tempo, que mesmo sendo ampla continua a ser local em seus nós.

De outro trabalho de Latour (2000b), vale ressaltar o foco dado no princípio de simetria para as explicações científicas porque tem como objetivo estabelecer a igualdade e, além disto, gravar diferenças e compreender os meios que os coletivos dominam uns aos outros (LATOUR, 2000b: 105). Por esse princípio, o autor afirma que somos todos híbridos, logo somos tecelões de redes. O que diferencia a ciência das demais formas de conhecimento é o tamanho (complexidade) das redes e a força dos laços.

Por fim, qual é o ponto em questão ao longo desta exposição sobre ciência em geral e a geografia em especial? O conhecimento científico é uma disputa por estabelecer verdades que são validadas por redes. A ser visto no capítulo três, os trabalhos recentes de geografia agrária estão circunscritos a definições da ciência amparada no objeto e nos conceitos, dentro de certos paradigmas ${ }^{36}$. O que se aponta aqui, com base na análise feita por Sposito (2001: 108) sobre os paradigmas dominantes na geografia do século XX, é a necessidade de abertura para o paradigma emergente das redes. Não se nega aqui os paradigmas dominantes, apenas procura-se questionar seus determinantes. O trabalho de Raffestin, apropriado nos trabalhos de geografia agrária pelo seu conceito de território, abre espaço para o jogo entre território e rede. Neste sentido, haveria uma continuidade de enfoque entre Raffestin e Latour. A análise desenvolvida por este último leva a uma radicalização da posição de Capel sobre o peso das comunidades científicas no caminhar das ciências. Assim, pode-se seguir o referencial teórico de Raffestin e manter uma postura em relação ao fazer científico baseada em Latour. Este trabalho insere-se nos limites do paradigma dominante, porém, coloca a noção de rede no lugar dos determinantes comuns, como será visto no capítulo sete.

\section{3) A relação entre ciência e justiça social}

$\mathrm{Na}$ modernidade, a relação entre ciência e justiça social remete ao pensamento socialista do século XIX. Marx, entre outros pensadores de sua época, compartilhava da máxima do movimento socialista-libertário: “de cada qual, segundo sua capacidade; a cada

estes dois conceitos ao invés de tratá-los como complementares, como propõe Raffestin. Sobre o uso dos conceitos de território e rede em geografia, ver também Dias (1995) e Souza (1995). 
qual, segundo suas necessidades" (MARX, 1961: 217). Ele mostra, no texto "Crítica ao Programa de Gotha" publicado em 1891, que o desafio é superar a noção de direito burguês baseado na igualdade, é preciso conceber a justiça diante da diferença. Ou seja, o direito igual diante de desiguais é um vício burguês.

Essa noção de justiça social ainda é uma referência no século XXI e está presente na discussão anterior sobre "alternativa" ao modo de produção capitalista, servindo como referência para autores como Singer, Oliveira, Stavenhagen e muitos outros.

Porém, se a geografia trata de diferentes meios e culturas como conciliá-la com um ideal de justiça social universal? É sobre esta pergunta que Harvey (1996) e Smith (1994) debruçam-se e tratam a justiça social como a grande questão da geografia no final do século XX. A resposta que encontram é a de uma tomada de posição, que eticamente é a mesma para os dois, no entanto, há divergências metodológicas que não cabe aqui aprofundar. Em seu livro de 1994, David Smith reconheceu o mérito de Harvey e antecipou a discussão que este geógrafo americano iria retomar dois anos depois. Porém, o geógrafo inglês construiu uma reflexão que, mesmo com pontos em comum, se opõe a Harvey por não se propor à construção de uma grande teoria sobre a justiça. Smith postula que as perspectivas científica e moral são diferentes mas não devem ser vistas inteiramente separadas e defende que a ciência deve assumir posições.

O conceito geográfico de lugar ("place") é trabalhado no livro de Harvey como ferramenta para a relação dialética entre o local e o global. Aqui podemos ver como o autor situa-se pessoalmente: há diferentes níveis de abstração quando se trata de militar no particular e ambicionar o global, de modo que nem sempre uma luta local vai ser progressista. Por isso, Harvey defende essa abordagem de diferentes níveis de abstração quando se busca uma transformação social total e não meramente local. Por sua vez, Smith reforça que nos estudos locais encontram-se formas de luta por justiça social.

Fazer a ponte entre experiências locais emancipatórias e uma globalização alternativa ao modelo neoliberal é o projeto de Santos, que o denomina de Reinventar a Emancipação Social (Cf. SANTOS [Org.], 2002: 13-77). Atualizando o debate sobre ciência e justiça social, a proposta de Santos $(2000)^{37}$ de um conhecimento emancipatório é uma contribuição central. Ele faz uma crítica à ciência moderna e defende uma ciência

\footnotetext{
${ }^{36}$ Sobre os paradigmas e/ou abordagens teóricas sobre o desenvolvimento do modo de produção capitalista na agricultura, ver Abramovay (1992) e Oliveira (1995).

37 O texto exposto de Santos (2000) é o primeiro capítulo chamado "Da ciência moderna ao novo senso comum", que consiste num aprofundamento de trabalhos anteriores do autor sobre ciência desde o final da
} 
pós-moderna. Mostra que aquela surgiu dentro de um contexto em que incluía regulação e emancipação social, mas com o tempo consolidou-se o "conhecimento-regulação" em detrimento do "conhecimento-emancipação". Outra crítica é a de que a ciência moderna consagrou o Homem como sujeito epistêmico e negligenciou o sujeito empírico. Por isso, a autor propõe rupturas com a ciência moderna e a constituição de um conhecimento emancipatório e uma ciência que seja auto-reflexiva.

Essa posição de uma ciência auto-reflexiva também auxilia na discussão anterior sobre ciência e ética. Será uma referência ao longo da tese. De acordo com o sociólogo português, a ciência moderna baseia-se na oposição ao senso comum. Esta oposição o autor denomina de primeira ruptura epistemológica. Dado que conhecimento científico e senso comum só existem em oposição, um é tão moderno quanto o outro; porém, há uma relação assimétrica entre eles. Por isso, Santos (2000) propõe uma segunda ruptura epistemológica: transformar o conhecimento científico num novo senso comum e que seja emancipatório. Neste sentido, procura-se, nesta tese, aprender com o Outro suas práticas potencialmente emancipatórias.

Vale ressaltar que o trabalho sociológico de Santos (2000) está em sintonia com o de geógrafos, como os de Lacoste e Harvey, para citar os mais conhecidos. Quer dizer, a análise sociológica vai trabalhar em conjunto com a geográfica, utilizando-se das discussões sobre mapas, escalas, projeções e simbolizações para estudar o Direito (Cf. SANTOS, 2000: 189-224).

Do mesmo autor, há uma referência para nos posicionarmos diante da questão do relativismo cultural e dos direitos universais. Propõe uma concepção multicultural de Direitos Humanos, para que estes deixem de ter um registro Ocidental que se pretende universal e de fato possam ser cosmopolitas. É preciso haver um diálogo intercultural, no sentido de pegar um pouco de cada lado. Pois, todas as culturas possuem concepções de dignidade humana, nem sempre concebida como Direitos Humanos, que são incompletas, distintas e que operam com princípios de igualdade e diferença (SANTOS, 1997). A posição da concepção multicultural de Direitos Humanos possibilita que o estudo do Outro não caia em julgamentos legalistas e/ou numa visão de tornar universal uma concepção Ocidental de direitos ${ }^{38}$.

década de 1980. O autor mostra que o paradigma da ciência moderna está em crise e propõe a superação da crise ao buscar constituir uma ciência pós-moderna que reinventa a emancipação.

${ }^{38} \mathrm{O}$ antropólogo R. C. de Oliveira (2000: 169-188) apresenta, numa reflexão a partir de sua experiência profissional, uma discussão sobre "etnicidade, eticidade e globalização" para defender a universalidade dos Direitos Humanos diante do relativismo cultural. 
Dada essa discussão sobre as referências de justiça e direito para classificar a ação do Outro, a teoria de Black (1998) sobre controle social - ou gestão de conflitos - propõe um concepção de justiça baseada na retirada de lei. O autor sintetiza aquilo que sociologicamente é conhecido como controle social ou gestão de conflitos através da análise da estrutura social do certo e do errado. Segundo a teoria, o controle social ocorre em todo o universo social onde quer que os indivíduos interajam e corresponde ao modo como as pessoas definem e respondem ao comportamento desviante. Logo, o controle social é sempre variável, conforme os contextos locais, sócio-culturais, históricos etc. Interessa destacar que ele pode variar de acordo com diferentes estilos, do mais formal e legal ao mais informal e casual. Como as formas e o montante de controle social variam de acordo com o espaço social, para se mudar uma configuração sócio-espacial deve-se mudar ou diminuir determinado tipo de controle social. Portanto, a contribuição do trabalho de Black está em mostrar que não há alteração no espaço social com a maior aplicação do controle social do estilo penal. Esta questão será trabalhada nos capítulos seis e sete. 


\section{Localização da fazenda}

FIGURA 1

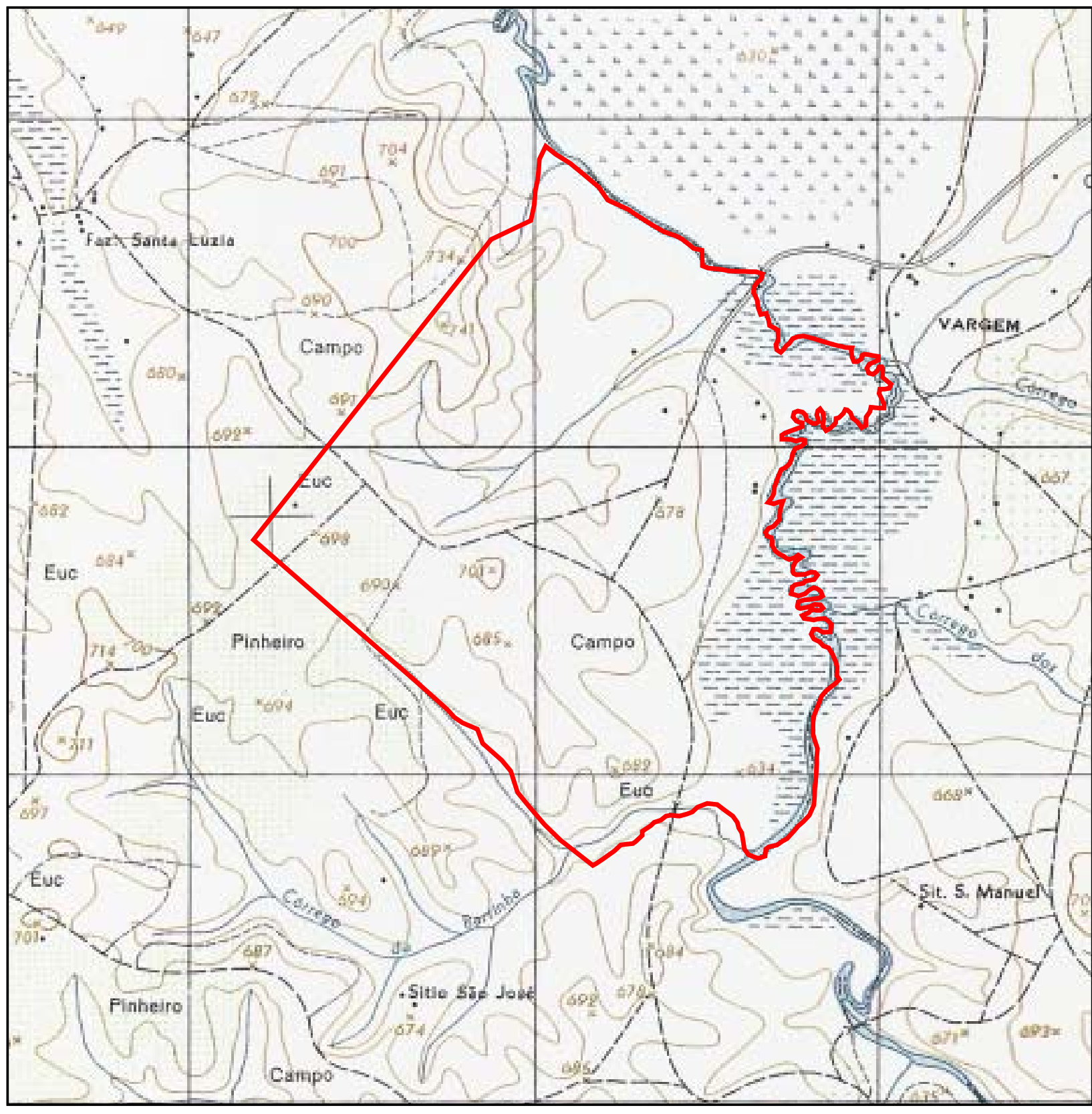

$1000 \mathrm{~m}$

0

1000

$2000 \mathrm{~m}$

Fonte: IBGE (1971).

Legenda

$\square$ Curvas de nível

7 Rio

Estrada

$\square$ Limites da fazenda 
Foto aérea com fazenda demarcada

FIGURA 2

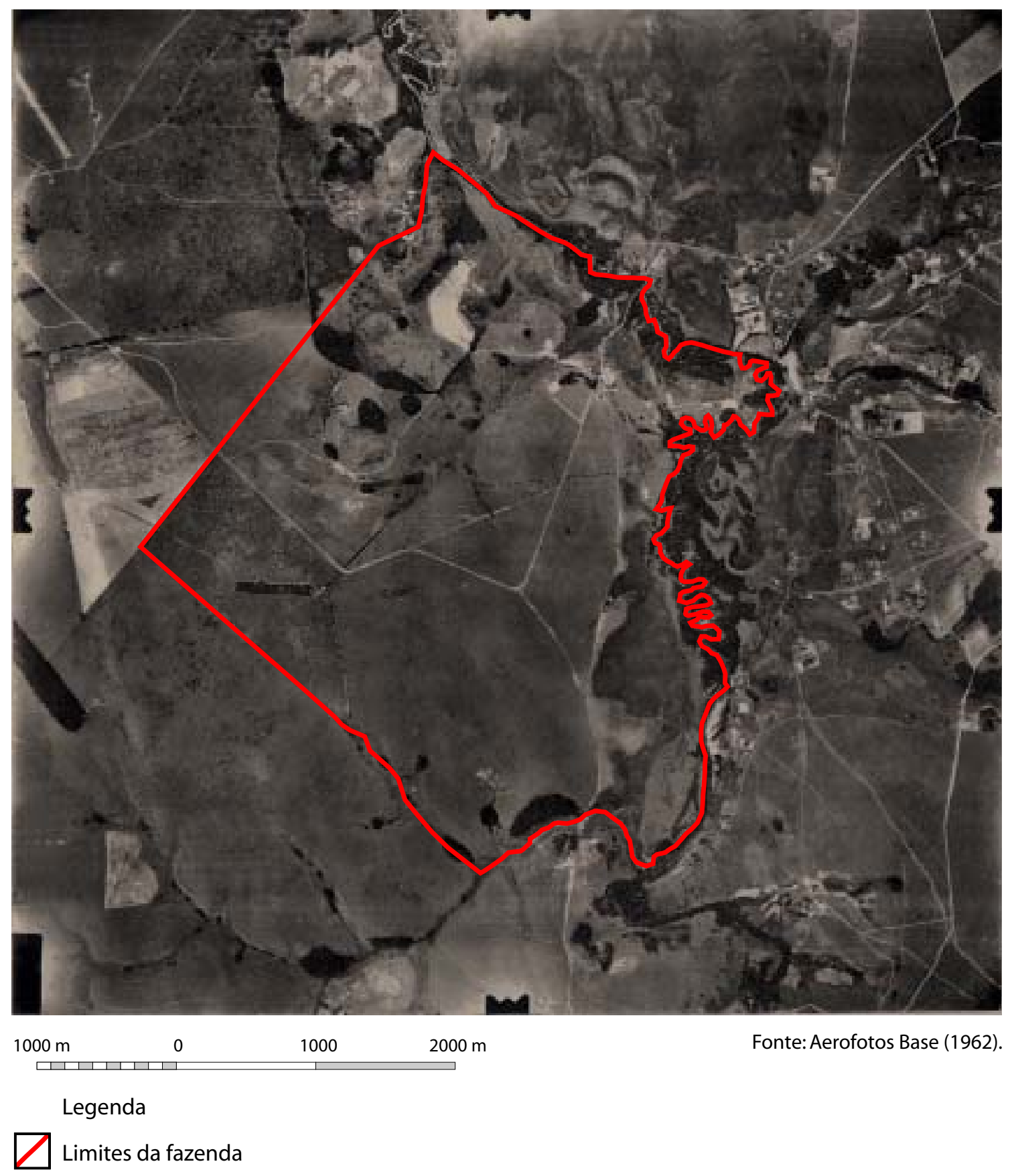




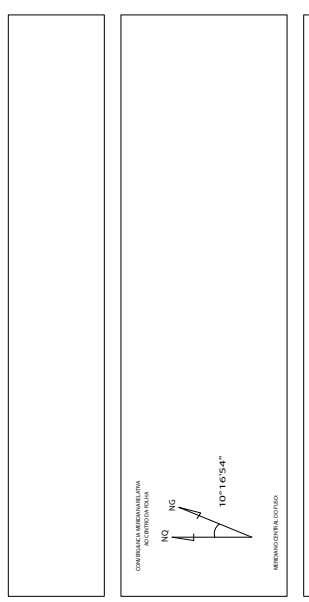

重

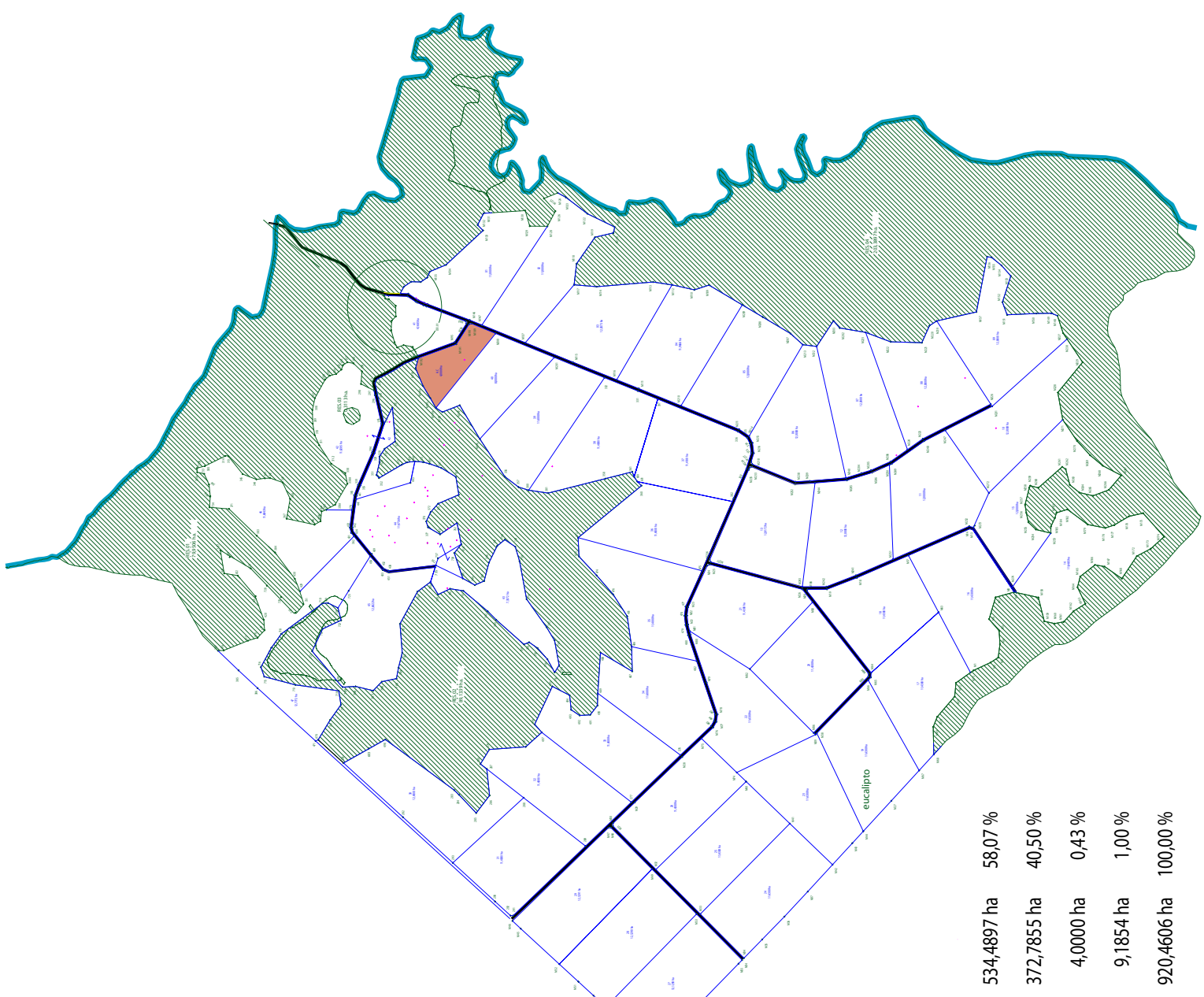




\section{Parte 1 - a teoria}




\section{Camponês, morador de rua e justiça social no centro da modernidade}

A intenção deste capítulo é situar o lugar do campesinato e da mendicância no pensamento moderno. Serão sempre os "resíduos" ou "o Outro" do moderno? É preciso mostrar porque a pobreza, em geral, tornou-se um tema para os modernos. O registro compreensivo sobre campesinato e mendicância está na fronteira do pensamento moderno e pode ser colocado como central para se analisar a sociedade atual. É no contexto desta problematização que será analisada a noção de modo de vida camponês em relação ao perfil de assentados que vieram das ruas da metrópole. Ao final, questionar a noção moderna de profissional abre espaço para compreender os assentamentos como locais de justiça social.

\section{As visões modernas sobre camponês e morador de rua}

A referência de exposição é a dos caminhos paralelos que o conhecimento percorre na modernidade, colocada por Santos (2000: 15-37) como conhecimento-regulação e conhecimento-emancipação. Segundo Santos, havia na origem da modernidade ocidental essas duas vertentes do conhecimento, porém, quando o modo de produção capitalista virou sinônimo de modernidade a regulação sufocou a emancipação. Ou seja, a necessidade de colocar ordem nas crises sociais foi mais forte do que o desejo de ampliar a igualdade e a liberdade.

Um dos objetos centrais do pensamento moderno é o de entender a ruptura dos modos de vida tradicionais e o surgimento do trabalhador assalariado. Autores de diferentes matizes conceberam a sociedade industrial como marcada por um rompimento com o modo de vida camponês, que é visto como "resíduo" de um outro tempo que não o moderno. Uma preocupação que atravessou a produção intelectual do século XIX ao XX foi a da formação de trabalhadores livres e disciplinados.

A produção familiar camponesa européia negaria o modo de produção capitalista porque, entre muitos outros pontos, não se basearia no trabalho assalariado. A mendicância seria, então, a "exclusão definitiva" do mercado de trabalho. O campesinato tem uma 
origem histórica anterior ao modo de produção capitalista e, por alguns autores, seria recriado por este modo de produção. Como o mote é a constituição do trabalhador livre, o camponês é visto como expropriado de suas terras, restando tornar-se proletário ou encontrar formas de reproduzir-se fora do assalariamento. A mendicância, por sua vez, é a condição de dependência de doação monetária alheia, o oposto da liberdade doada pelo contrato trabalhista.

A formação da chamada sociedade do trabalho teve como contrapartida a tutela sobre a mendicância e demais marginalizados. Isto mostra que a mendicância e outras formas de exclusão do Contrato social, ao contrário dos sujeitos sociais claramente definidos, são construídas por meio de mecanismos de controle social.

A seguir são apresentadas as idéias de alguns expoentes centrais do pensamento moderno em relação ao tema proposto. A seleção baseou-se na relevância dos nomes e de suas idéias, por suas visões sobre camponês e/ou mendicância, por serem fundadores de modelos analíticos e por poderem ser agrupados nas referências de conhecimentoregulação e conhecimento-emancipação.

$\mathrm{Na}$ vertente do conhecimento-regulação, há o pensamento de Comte e de Ratzel, por suas posições teóricas e políticas. O pensamento de Comte executa os marcos da modernidade: separar a ciência da filosofia e da religião, dar a ela um estatuto normativo da vida em sociedade e, num segundo momento, colocá-la em xeque. Num primeiro momento, ele aposta totalmente na ciência em detrimento da religião e, depois de algumas décadas, desilude-se e cria os postulados de uma religião da humanidade. Percorre-se aqui esse segundo momento, e não o Comte do Curso de Filosofia Positiva, de 1830-1842, nem o do Sistema de Política Positiva, de $1851^{1}$.

No livro Catecismo Positivista, publicado em 1852, a mendicância para Comte não era vinculada à exclusão do convívio social. Pelo contrário, no culto público da sua religião da humanidade haveria uma festa, dentro das celebrações mensais, dedicada à "mendicidade". Nesse trecho, o pai da Sociologia refere-se à "mendicidade" como uma “imperfeição pessoal” que nenhuma ordem humana poderia prevenir (COMTE, 1983: 200). Na morfologia espacial presente na obra do autor, os trabalhadores têm reconhecida importância para o funcionamento e manutenção da pirâmide social e, entre eles, estão os agricultores com a responsabilidade de alimentar o conjunto da sociedade. Fica claro nesse modelo uma acentuada ordem hierárquica, semelhante ao modelo estamental.

\footnotetext{
${ }^{1}$ Para uma análise crítica da vida e obra de Comte, ver Bruni (1989).
} 
Polemizando com as obras de Comte, Ratzel (1990) realiza uma discussão epistemológica sobre as categorias "sociedade" e "meio ambiente", porque aquele autor teria reduzido o uso da categoria "meio ambiente" a "meio intelectual", desprezando o papel do solo na vida em sociedade.

Dada essa importância da ligação com o solo, Ratzel faz uma distinção entre pastores nômades e agricultores sedentários. "Todas as colonizações exclusivamente agrícolas (...) tendem à letargia e são tingidas de inabilidade política" (RATZEL, 1990: 190).

O ponto central da distinção feita por Ratzel está na concepção de “civilização”. Na origem, a civilização tem estreita ligação com o cultivo do solo, o autor inclusive chama a atenção para o fato de a palavra "civilização", em muitas línguas, ter um significado em comum com "agricultura". Porém, com o desenvolvimento a "civilização" perde seu vínculo com o solo. O autor trabalha com as idéias de "mais" e "menos" civilizado, estabelecendo uma evolução. "Mais civilizado" não quer dizer independente das condições naturais, pelo contrário, significa maior proveito do meio. Neste sentido, pastores exploram mais as condições naturais do que os agricultores, que se fixam a um mesmo solo. Vale ler o próprio autor, que sintetiza a superioridade dos caçadores-pastores em relação aos agricultores, num registro datado historicamente:

À medida que um povo cresce, sua civilização se libera do solo e quanto mais vai se desenvolvendo tanto mais vão se criando os órgãos que servem não apenas à fixação. Poder-se-ia quase dizer que ao agricultor é inata uma debilidade que se explica facilmente tendo como base o fato de que ele não tem hábito das armas, e ama o seu poder e a vida sedentária, o que debilita nele a audácia e o espírito empreendedor. A mais elevada medida de manifestação de força no âmbito político encontra-se pelo contrário nos caçadores e nos pastores, que sob muitos aspectos se contrapõem como natural antítese ao cultivador: e sobretudo nos pastores, que unem à mobilidade a tendência a se deslocar de um lugar a outro em grandes massas, e à força a disciplina. Aqui entra em ação, e favoravelmente, precisamente aquilo que torna difícil ao cultivador desenvolver esta força: a ausência de sedentarismo, a mobilidade, o exercício da força física, da coragem e da prática das armas (RATZEL, 1990: 137).

Por mais que Ratzel valorize a ligação material com o solo, ele é um dos principais autores que consagra a visão moderna de que o camponês é "menos" civilizado do que outros grupos sociais. Pode-se deduzir que o conhecimento-regulação, para classificar, hierarquiza o mundo. 
$\mathrm{Na}$ vertente diametralmente oposta, está o conhecimento-emancipação de Marx e Reclus. Com esses autores fica claro que o registro da emancipação passa pelo fim da propriedade privada dos meios de produção, ou seja, da terra e do capital.

Marx expunha sua visão sobre os camponeses e os mendigos na França da época, no mesmo ano em que Comte publicava seu Catecismo Positivista. Na conhecida análise crítica de "O 18 Brumário", escrito em 1852, Marx descreve Luís Bonaparte como o "chefe do lumpen-proletariado", aquele que se apóia na "escória", formada por "vagabundos", "trapaceiros", "mendigos" e demais "decadentes" das ruas de Paris de 1849.

Mais à frente, o autor trata dos pequenos camponeses. Eles possuem um "modo de produção" que os isola, a pequena propriedade impede qualquer aplicação dos avanços do modo capitalista. Os camponeses possuem um "modo de vida" que os opõem às demais classes sociais e isto os constitui como classe. Mas, como não há ligação nacional nem organização política alguma entre eles, não formam uma classe. "Não podem representarse, têm de ser representados" (MARX, 1978: 397). Assim, vêem em Luís Bonaparte seu grande representante (e, por isso, Marx os despreza). O autor é ambivalente em relação aos camponeses, eles são e não-são classe ${ }^{2}$. Essa ambivalência do autor, além de proporcionar densidade ao trabalho, permite que haja entre os seguidores de seu pensamento distintas linhas que colocam tanto a extinção progressiva do campesinato, como Lenin e Kautsky, quanto a sua reprodução por meio do modo de produção capitalista, como Shanin e Lefebvre.

Em trabalho posterior, Marx (1985) explica que a formação da classe trabalhadora na Inglaterra deu-se com a expropriação dos camponeses. Na história do modo de produção capitalista houve uma acumulação primitiva, que consistiu no cercamento de terras, que resultou na migração de camponeses expropriados para as cidades. Assim, os problemas da expropriação camponesa e da mendicância estariam juntos há pelo menos quinhentos anos. $\mathrm{O}$ autor mostra que na acumulação primitiva entre os séculos XV-XVI, condição necessária para o modo de produção capitalista, está o início da formação dos trabalhadores livres e assalariados. Essa acumulação consistiu justamente na separação histórica entre o produtor e o meio de produção.

\footnotetext{
${ }^{2}$ Sabe-se que foi, somente no terceiro volume de $O$ Capital, que Marx esboçou uma não-acabada teoria das classes sociais, onde define a existência de apenas três: a burguesia, proprietária de capital; o senhor de terra; e, o proletariado, proprietário de força-de-trabalho.
} 
O pensador alemão expõe o quanto esse processo de acumulação primitiva e de conseqüente formação de trabalhadores livres e assalariados foi violento. Os camponeses foram expulsos dos campos e tiveram seus meios de produção expropriados. Houve, em consequiência, nas cidades um processo de incriminar os "vagabundos", via legislação, e de disciplinar os trabalhadores assalariados.

Assim, o povo do campo, tendo sua base fundiária expropriada à força e dela sendo expulso e transformado em vagabundo, foi enquadrado por leis grotescas e terroristas numa disciplina necessária ao sistema de trabalho assalariado, por meio do açoite, do ferro em brasa e da tortura (MARX, 1985: 277).

Marx verificou a ocorrência de uma expulsão em massa dos campos que não pôde ser absorvida totalmente nas cidades. Como uma multidão flutuante de pobres nas cidades, os trabalhadores que não foram empregados pela manufatura converteram-se em esmoleiros, assaltantes e "vagabundos". Isto originou uma "legislação sanguinária" contra a "vagabundagem". Por exemplo: "Henrique VIII, 1530: Esmoleiros velhos e incapacitados para o trabalho recebem uma licença para mendigar. Em contraposição açoitamento e encarceramento para vagabundos válidos" (MARX, 1985: 275). No entanto, o que se constata com o autor é que todos aqueles expropriados do campo são membros da classe trabalhadora. Quer dizer, a expropriação do camponês, a migração para as cidades e o controle social sobre eles estão na formação da classe trabalhadora.

Bastante atacado por Marx ${ }^{3}$, o geógrafo e militante anarquista Reclus mostra uma visão positiva do camponês. Em 1881, destaca o papel do camponês na ação de modificação das condições naturais. Na visão dele, é pela cultura - no sentido de cultivar a terra - que o homem se apropria do solo pela primeira vez; as tribos nômades de pastores, caçadores, ou pescadores, em nada modificaram a superfície da Terra. Com sua tenacidade de trabalho, o camponês realiza obras equivalentes às pirâmides do Egito. Mesmo sem os recursos da indústria moderna, ele é capaz de destruir e remover rochas para tornar o solo arável, como, por exemplo, os camponeses que vivem na encosta do vulcão Etna, na Itália, que a cada nova erupção reconstroem suas lavouras. Outro exemplo é o dos moradores da ilha de Java que, para o plantio de cereais, construíram degraus concêntricos contornando algumas colinas da base ao cume (RECLUS, 1985: 41-55) ${ }^{4}$.

\footnotetext{
${ }^{3}$ Ver Manoel Correia de Andrade, Introdução - a atualidade do pensamento de Élisée Reclus, in: Reclus (1985: 15-6).

${ }^{4}$ É curioso notar que essa visão de Reclus sobre os camponeses em oposição ao pastores é inversa a de Ratzel, exposta anteriormente, sendo que os dois autores são contemporâneos e estudaram com Ritter.
} 
Em outro texto, chamado "A propriedade e a exploração da Terra", publicado em 1908, Reclus questiona a propriedade privada na civilização moderna. Mostra que até o século XII, em algumas regiões da Europa, o indivíduo que roçasse um terreno tornava-se seu proprietário e que o princípio de que o uso legítimo da terra advém do cultivo com os braços é reconhecido em todo o Oriente. Ele analisa o fato de que a influência do direito romano na sociedade moderna obscureceu a percepção de que a forma de propriedade individual é recente em comparação com as diversas formas de propriedade coletiva de outras épocas. Nota-se aqui a união entre ciência e militância.

Seja retratado como miserável, como nas pinturas européias do século XVII, ou amado, como pelos romancistas do XIX, o geógrafo francês constata que o camponês, como foi conhecido, está desaparecendo por causa da mudança no modo de propriedade da terra. A produção tradicional está perdendo a concorrência com os métodos "mais científicos". Conclui que as classes sociais tendem a se confundir, assim como ocorreu com os senhores de terra e os senhores de indústria, operário do campo e da cidade misturam-se (RECLUS, 1985: 75-98).

Retomando, o enfoque de Comte sobre a mendicância é de naturalizá-la e individualizá-la ao colocá-la como uma "imperfeição pessoal" que a sociedade não elimina. Ratzel associa o sedentarismo dos agricultores a certo atraso de civilização, vê neles uma indolência natural. Para Marx, num trabalho teórico como O Capital, a mendicância é colocada como um produto do processo histórico de cercamento de terra e de acumulação primitiva de capital. Portanto, a mendicância é resultante da expropriação do camponês. Logo, a destruição do modo de vida camponês é condição para o modo de produção capitalista. Num trabalho de análise histórica mais pontual, como O 18 Brumário de Luís Bonaparte, o autor faz um escárnio do posicionamento político de mendigos e camponeses. Nesse texto de Marx, os camponeses são e não-são classe. Na visão de Reclus, há o oposto a de Ratzel, o sedentarismo do camponês é mais responsável pela civilização do que o movimento de pastores. Há um elogio da classe camponesa, claramente a presença de algo "bom" que estaria chegando ao fim num mundo em transformação em que passou a dominar o "mau" da propriedade privada.

Por fim, interessa destacar que o recorte no pensamento moderno privilegiou duas visões de mundo, uma conservadora e "hierarquizante" e outra progressista e "horizontalizante". Enquanto no positivismo de Comte e Ratzel há uma visão de mundo conservadora, que postula uma sociedade inteiramente hierarquizada quase estamental, de uma concepção de espaço social totalmente verticalizado, no pensamento socialista de 
Marx e no anarquista de Reclus, a "utopia" é o fim das hierarquias, a horizontalidade máxima, ou seja, a configuração espacial da sociedade deve ser, por excelência, simétrica. Importa, como futuro instrumento de análise, a presença dessas duas forças sócioespaciais: a vertical, ou assimétrica, e a horizontal, ou simétrica. Pois é possível encontrar nas interpretações recentes sobre camponeses leituras que mostram, entre os trabalhadores rurais, tanto um caráter "conservador" baseado na hierarquia familiar quanto algo voltado a um cooperativismo horizontal.

\section{A crítica à visão moderna e a história da pobreza}

É preciso sair do registro do pensamento moderno para se fazer a crítica as essas visões que tratam de maneira ambígua e ambivalente os camponeses e os moradores de rua. $\mathrm{Na}$ modernidade, o poder individualizante recai, em primeiro lugar, sobre os corpos desses tipos "desviantes". A variedade de classificações para camponeses e moradores de rua no pensamento moderno corresponde justamente a um esforço de constituí-los como sujeitos. Podemos visualizar esse processo a partir do questionamento da "epistéme" moderna realizado por Foucault.

Este autor escreve que o corpo está mergulhado num campo político, que constitui um sistema de sujeição. Esta sujeição pode ser obtida não só de forma violenta, mas também de maneira sutil (FOUCAULT, 1993a: 28). Na época dos suplícios, o corpo era mutilado porque estava se punindo o crime e acreditava-se na libertação da alma. Com o predomínio da prisão como forma de punição, não se toca mais o corpo porque visa-se atingir algo mais que este com a perda da liberdade. Por isso, ele vai dizer que a alma é a prisão do corpo (FOUCAULT, 1993a: 32). Apresenta-se, então, o que ele chamou de história da alma moderna e a importância dada em seu trabalho ao corpo.

Com as disciplinas a que Foucault refere-se, temos uma troca do eixo político da individualização. No regime feudal havia uma individualização "ascendente", isto é, quanto mais um homem era detentor de poder ou de privilégio mais marcado como indivíduo ele era.

Num regime disciplinar a individualização, ao contrário, é "descendente": à medida que o poder se torna mais anônimo e mais funcional, aqueles sobre os quais se exerce tendem a ser mais fortemente individualizados; e por fiscalizações mais que por cerimônias, por observações mais que por relatos comemorativos, por medidas comparativas que têm a "norma" como referência, e não por genealogias que dão os ancestrais como ponto de referência; por "desvios" mais que por proezas. Num sistema de disciplina, a criança é 
mais individualizada que o adulto, o doente o é antes do homem são, o louco e delinqüente mais que o normal e o não-delinqüente (FOUCAULT, 1993a: 171).

Portanto, segundo esse pensador francês, o indivíduo é produto do poder disciplinar. Sendo assim, o que a sociedade moderna realizou foi individualizar camponês e mendigo e, conseqüentemente, torná-los sujeitos pesquisáveis.

O trabalho de Castel (1978) complementa a abordagem de Foucault. Ele apresenta um período histórico, classificado como idade de ouro do alienismo, no qual a sociedade liberal, baseada no Contrato, vê-se diante de uma lógica que rompe com a sua própria lógica: a do louco. Este passou a ser visto como despossuído de razão e, conseqüentemente, deve ser tutelado, não pelo serviço jurídico-administrativo, mas pelos médicos. A idade de ouro do alienismo vai de 1790 até 1838, período de alta concentração de internação dos loucos.

Segundo Castel, num período anterior ao descrito acima, aparecem medidas com relação à mendicância, por exemplo, a criação do depósito de mendigos, em 1767, pelo poder real. O vaguear pelas ruas passou a ser visto como algo perigoso. Já durante a Assembléia Constituinte - pós Revolução Francesa - foi criado o Comitê de Mendicância, que construiu hospitais para mendigos. Relacionado a essa época, o autor cita Cabanis: “A mendicância forma o primeiro grau, não digo de delito, mas se se pode expressar assim, de disposição para atos que perturbam a ordem social (...)" (Apud CASTEL, 1978: 40). Percebia-se, então, que não se poderia punir porque não se oferecia trabalho. É o começo da assistência aos pobres. Deixa-se de condenar moralmente a mendicância e transforma-se a assistência em política de sujeição das classes populares. Posteriormente, com o Estado Napoleônico, voltam a interdição da mendicância e o depósito de mendigos. E, no final do século XIX, precisamente em 1890, ocorrem mais de 32 mil condenações por vagabundagem. Constata-se, portanto, que as políticas sobre a mendicância variam ao longo dos séculos XVIII e XIX. Com a descoberta, no século XVIII, do trabalho como fonte de riquezas, o "indigente" passa a ter que ocupar outro lugar na estrutura social.

Prosseguindo, Castel demonstrou que o alienismo foi a maneira encontrada pela sociedade liberal de tratar de uma lógica que rompe com sua própria lógica. A idéia de uma sociedade baseada num Contrato social não se sustenta facilmente, porque vários setores da população estão fora dele. Para o Contrato se manter são necessários mecanismos de tutela sobre o criminoso, a criança, o mendigo, o proletário e o louco. Com isso, a estratégia de controle social não deve mais ser entendida como uma coerção brutal, mas como a "instauração de dispositivos práticos por responsáveis bem intencionados" 
(CASTEL, 1978: 19). Assim, Castel ao estudar o tratamento dispensado ao louco na passagem do século XVIII para o XIX, apresentou certos limites de uma racionalidade social que se iniciava.

Para a formação de trabalhadores "dóceis", dispositivos disciplinares foram criados. "Pobres e marginalizados" foram transformados em sujeitos pesquisáveis, ou objetos científicos, e, consequentemente foram colocados para trabalhar em fábricas, ou foram presos, ou internados.

Como visto, a crítica ao pensamento moderno demonstrou que a pobreza havia se tornado questão, no sentido da individualização dos pobres, loucos, crianças, mendigos e trabalhadores. Assim, o século XIX assume definitivamente como um problema social aquilo que vinha sendo tratado como questões de disciplinar a mão-de-obra e de aplicar punições. Além das "leis dos pobres" no século XVI, descritas por Marx, a Inglaterra criou as "Casas de Trabalho" no século XVII como forma de transformar "vagabundos" em trabalhadores. Bresciani (1986) mostra como essas políticas constituíram a "Sociedade do trabalho", que é como a sociedade moderna ocidental imagina-se. "As Leis dos Pobres e as Casas de Trabalho cuidaram de convencer o homem pobre de que ainda a melhor condição que ele podia aspirar era aquela que um emprego regular lhe proporcionava" (BRESCIANI, 1986: 24). Já no século XIX, as cidades emergiram como grande tema para as "Ciências do Social" devido à explosão urbana e às doenças transmitidas por contato social. Então, o espaço urbano apareceu como um "meio ideal para o crescimento e a transmissão dessas massas malignas" (BRESCIANI, 1986: 27).

As classes populares passaram, nas últimas quatro décadas do século $\mathrm{XX}$, a ter suas histórias recontadas. O cotidiano e a vida do homem comum dos séculos XVI ao início do XX viraram temas para se entender a formação da classe operária, as mudanças nos costumes e as resistências às transformações. Destacam-se os trabalhos de Thompson (1979, 1993), que analisam a formação da classe operária inglesa, no século XVIII, pelo recorte da disciplinarização do tempo e das revoltas baseadas na noção de "economia moral" em contraposição à economia capitalista, e, o de Perrot (1992), que, similar ao de Thompson, estuda a disciplina industrial na França do século XIX. Há também o texto de Schmitt (1990), “A história dos marginais", que retoma a análise de que nos séculos XIV e $\mathrm{XV}$, na Inglaterra e na França, ocorreu a distinção entre pobres "de verdade e falsos", em que os primeiros recebiam assistência e tinham direitos a mendigar, enquanto os segundos eram perseguidos. Começaram naquele período as ações que associavam a miséria ao crime. Já a chamada Idade Clássica foi o período do grande internamento, como visto 
também com Castel. “A expulsão dos mendigos não basta para exorcizar o medo do crime, nem para satisfazer o desejo de higiene pessoal - a partir de então, eles são internados" (SCHMITT, 1990: 278). Os que não são internados são "reformados" pelo trabalho forçado nas workhouses, tratado também por Bresciani (1986). Schmitt (1990) chama a atenção para o fato de que por meio dos discursos e das práticas de exclusão manifestam-se as transformações sociais fundamentais.

Não cabe aqui esgotar essa historiografia, mas enfatizar que houve uma mudança na política social dos últimos vinte anos ocorrida nos Estados Unidos e que se espalha pelou mundo: a substituição do Estado de Bem-Estar Social pelo Estado penal. Com o declínio do Welfare State, ocorrido na virada dos anos 1980 para os anos 1990 nos Estados Unidos, as políticas assistenciais e de direitos sociais aos pobres foi substituída pelo criminalização da pobreza. Segundo Christie (1999), esse crescimento da penalização espalha-se pela Europa e os países do norte oscilam entre políticas sociais e carcerárias. Nota-se, enfim, que ao longo de quatro séculos as políticas de criminalização da pobreza retornam, intercaladas com políticas assistenciais. É Castel quem bem interpreta o contexto atual, chamando-o de época da "insegurança social", em que a busca crescente de proteção cria mais insegurança. Ou seja, vive-se cercado de sistemas de segurança, que são complexos, frágeis e possuem o risco de falhar; portanto, ser protegido é estar ameaçado. Neste sentido, se o proletariado representou no século XIX o papel de "classe perigosa", assiste-se hoje em dia ao retorno dessa imagem com as populações das periferias (CASTEL, 2005: 8-56). Essas questões serão retomadas no próximo capítulo quando se tratará dos moradores de rua.

\section{A posição não-moderna: moradores de rua e camponeses são "híbridos"?}

Dos retratos modernos, constatam-se ambigüidades e ambivalências das teorias e das políticas para se tratar de camponeses e de moradores de rua. Estes são produtos de processos históricos ou de condições naturais? Camponeses e moradores de rua são agentes sociais dignos ou desprezíveis? Por meio da critica foucaultiana, pode-se constatar que a realização do pensamento moderno foi problematizar os "marginalizados". Porém, os modernos realizaram esse percurso de modo oscilatório: ora os colocando como produtos histórico-sociais, ora como resultados da natureza, ora como algo perene, ora como intermitente. Ao se questionar as interpretações que estabelecem a modernidade como uma ruptura inexorável do "passado" tradicional, encontra-se uma outra perspectiva. A oscilação no pensamento moderno ao tratar de mendigo e camponês pode ser resolvida na 
visão não moderna ao colocar a formação de "híbridos", que não são explicados pela natureza nem pela sociedade. Poder-se-ia dizer, com base na teoria de Latour (2000b), que camponeses e mendigos foram construídos pelo pensamento moderno como "híbridos", ou "quase-objeto", que consiste numa mistura de coisa natural e símbolo social e que não ocupa o lugar de sujeito e nem de objeto que a "constituição moderna" lhe reserva, por isso, pode estar numa posição mediana entre os dois.

Latour chama de "constituição moderna" o acordo que aceita a dupla separação: entre o homem e um deus e entre o humano e o não-humano. Ele elenca quatro garantias da constituição moderna: a exterioridade da natureza em relação ao mundo dos homens (e mulheres); a sociedade ser formada por homens e não comportar algo não-humano; a separação total entre o trabalho dos híbridos e o trabalho de purificação; e, o afastamento de deus das leis de natureza e da política. Porém, essas garantias da modernidade nunca ocorreram plenamente e a constituição moderna propicia o aumento de híbridos, que ela mesma nega. O autor não nega a modernidade. Segundo ele, a modernidade "é uma força acrescentada a outras, as quais por muito tempo teve o poder de representar, de acelerar ou de resumir, mas a partir de agora não mais, não completamente" (LATOUR, 2000b: 45). Isto mostra que a constituição moderna não permite sua própria compreensão, em decorrência de o mecanismo crítico da modernidade encontrar-se esgotado. Por isso, propõe a atitude não moderna (ou a-moderna): seguir ao mesmo tempo a constituição moderna e aquilo que ela proíbe ou permite, o estudo do trabalho de produção de híbridos e o de eliminação destes. É uma releitura da história que não vê mais a modernidade como uma ruptura inexorável com um passado qualquer.

Assim, a posição de Latour é não-moderna, no sentido de propor um outro olhar sobre o que se convencionou chamar de modernidade. Segundo ele, há tantas concepções de modernidade quanto de autores que a estudam, porém é possível estabelecer um ponto em comum: o tempo. O moderno é uma ruptura com o tempo passado e também uma forma de estabelecer um combate entre vencedores e aqueles que ficaram para trás; conseqüentemente, é duas vezes assimétrico. A hipótese seguida pelo autor é que a palavra "moderno" designa dois conjuntos de práticas distintas, que recentemente perderam a separação. A primeira diz respeito à criação de híbridos entre natureza e cultura, via "tradução" ou "mediação". A segunda é a produção da distinção entre o que é humano e o não-humano, via "purificação". A ciência moderna faz a purificação, distinguindo claramente entre o mundo das relações sociais (humanas) e o universo da natureza e das coisas inanimadas (não-humano), por um lado. De outro, também cria formas híbridas de 
natureza e cultura. No entanto, contemporaneamente há uma proliferação de híbridos, pois as práticas de "purificação" e de "tradução" não são mais tão distintas.

A perspectiva reivindicada por Latour é uma forma de explicação que procura expor a natureza das coisas e o contexto social, sem se reduzir a uma ou a outro como determinante. A natureza, a sociedade e o discurso não são mais os fatores de explicação da realidade. Enquanto a ciência moderna coloca a natureza, a sociedade e o discurso, distintamente, como chaves para analisar os fenômenos, na posição não-moderna, os "híbridos" vão explicar a natureza, a sociedade e o discurso. São "híbridos" porque estão a meio termo entre natureza e cultura, por isso não se pode mais separar natureza de cultura. O autor propõe colocar-se no ponto médio entre a produção de atributos humanos e nãohumanos; posicionar-se no lugar onde irrompe a mediação entre as "naturezas-culturas".

Por fim, Latour acaba com a posição científica de busca da essência, sem, no entanto, abrir mão da ciência para explicar a realidade. E a "realidade" é para ele aquilo que resiste. A ciência moderna não dá mais conta da explicação da proliferação de híbridos. Para ele, os "quase-objetos quase-sujeitos”, apenas, traçam "redes”, são reais, coletivos, discursivos e instáveis e arriscados; não somos nós que os criamos, mas eles que nos definem através de sua circulação e nos ligam uns aos outros. Eles traçam "redes", que "são ao mesmo tempo reais como a natureza, narradas como o discurso, coletivas como a sociedade" (LATOUR, 2000b: 12). As redes realizam mediações entre o que é humano e o não-humano, entre natureza e cultura; elas são mais ou menos longas e mais ou menos conectadas, não são globais nem locais.

O trabalho de Latour realiza um avanço em relação ao pensamento moderno porque questiona o registro epistemológico deste baseado na ciência. Para o autor, o conhecimento científico e, simetricamente, as demais formas de conhecimento traçam redes. Essa reflexão epistemológica colocada pelo autor ressoa ao longo desta tese.

\section{Modo de vida camponês e a inclusão de moradores de rua na luta pela terra}

Acredita-se haver um desafio tanto para os cientistas quanto para o MST de conciliar o que é tido como modo de vida camponês com o perfil dos novos assentados ("novo campesinato", como expresso em MIRANDA, 1998: 24), como será visto no capítulo três.

No Brasil, há uma tradição analítica aberta por Candido (1998) que é a de tratar camponês como "modo de vida". É toda uma cultura (caipira), que não se restringe a um 
tipo de trabalho e que se insere numa relação de dependência do proprietário de terra. A categoria modo (ou meio) de vida no trabalho de Candido foi retirada de Marx, que diz que os Homens, ao produzirem seus meios de vida, também produzem sua vida material. Mas esse modo de produção não deve ser entendido só como reprodução física dos indivíduos, é mais do que uma forma de atividade é um "modo de vida". Muitos trabalhos nas diversas áreas do conhecimento acadêmico seguiram essa tradição de tratar o campesinato como "modo de vida".

A concepção de que um modo de produção implica um modo de vida foi enfatizada nos estudos sobre campesinato no Brasil, ao longo dos anos 1970 e 1980, que estabeleciam a contraposição entre o "modo de produção capitalista" e o "modo de vida camponês". Interessa dessa concepção o fato de as lutas camponesas serem interpretadas como formas de resistência à reprodução ampliada do modo de produção capitalista, que sistematicamente solapa a vida camponesa. $\mathrm{O}$ modo de produção capitalista alimenta-se de outros modos de produção e, assim, os destrói, não sem resistências (e o reconstrói, segundo as leituras clássicas baseadas em Marx, Lefebvre e outros, presentes nos trabalhos sobre o campesinato brasileiro de José de Souza Martins, Ariovaldo Umbelino de Oliveira, entre outros, e do norte-americano David Harvey, sobre o mundo urbano). A luta pela terra do camponês posseiro ou do sem terra é para, através do trabalho com a terra, reproduzir sua cultura, e não uma mera busca de trabalho.

Mesmo compartilhando-se desse posicionamento, aponta-se um problema presente nessas interpretações: uma visão que privilegia uma essência camponesa. A busca de uma essência do modo de vida camponês, ou de um ethos campesino, continua a ser um tema presente em teses recentes sobre o MST, como será visto no capítulo três. Isto implica um problema analítico: algumas monografias descrevem um "novo" camponês nos assentamentos do MST e, ao mesmo tempo, afirmam a necessidade de que haja entre os assentados um ethos camponês. Se há um "novo" camponês, o "caráter essencial” do camponês não pode ser mais o mesmo. A questão que aparece ao longo desta tese é que o chamado caráter camponês pode ser usado como forma de discriminação entre os assentados.

Posta a discussão sobre camponês como "modo de vida", voltam-se os olhos para o MST, que se autodenomina, em seu nascedouro, de "trabalhador rural" e não de "camponês". Stedile, membro da direção nacional, reconhece - a partir de meados da década de 1990 - que o MST é um "movimento camponês", porém diz que o termo "camponês" não teria sido adotado porque é elitista, nunca foi usado pelo próprio lavrador 
e foi introduzido no país pela militância do Partido Comunista do Brasil. Para Stedile, o MST é diferente dos movimentos camponeses anteriores, em parte, porque tem um caráter "popular", no sentido de englobar todos os membros da família e não apenas os homens adultos e, principalmente, porque o "trabalhador rural” não é só o lavrador e sim também o técnico agrícola, o padre, os militantes urbanos etc. Ou seja, unem-se no MST os "mãos lisas" e os "mãos grossas" (STEDILE e FERNANDES, 1999: 31-38). Nesse sentido, o MST inclui também aqueles que não têm um modo de vida camponês, dos chamados “intelectuais orgânicos" aos moradores de rua. O que representa um desafio para o Movimento.

\section{Modos de vida moderno e tradicional e a luta por justiça social}

A carreira profissional é uma característica básica da sociedade moderna burocrática, segundo Weber (1967). O profissional representa o modo de vida moderno, do modo de produção capitalista. Mas, privilegiar as profissões é um meio de deslegitimar outros modos de vida.

Há um desafio na interpretação dos assentados: lidar com pessoas que vieram de experiências diversas, sem cair na reivindicação de um caráter camponês. A questão passa pelo fato de que as experiências anteriores dos assentados podem contribuir com a vida no assentamento e pela perspectiva de que ser camponês e a gestão pública do assentamento podem ser modos passíveis de aprendizado.

As ações do MST restituem aos sem terra os meios para produzir e se reproduzir como meio de vida e "reabilitam" os assentados, ou acampados, com o "saber-fazer" (por exemplo, poder fazer hortas medicinais). O desafio para se entender o papel do "novo" assentado do MST pode aparecer também da seguinte forma: por um lado, quanto mais o trabalhador foi expropriado de seu conhecimento para produzir na terra, maior dificuldade terá para se adaptar à volta ao campo. Por outro lado, o MST trabalha com uma visão ampla de trabalhador rural que não inclui só o lavrador, o que propicia que o sem teto seja assentado. Então, o "modo de vida", como uma construção social, pode ser considerado como passível de aprendizado, e não como uma característica intrínseca para ser um assentado duradouro.

Resgatam-se aqui as idéias de uma obra da década de 1970, que possibilitam interpretar as contribuições sociais dos destituídos de um ethos profissional, característico do modo de produção capitalista, na luta por justiça social. Ivan Illich, em seu livro $O$ Direito ao Desemprego Criador, escreve que "(...) a qualidade de uma sociedade e de sua 
cultura dependerão da condição de seus desempregados: serão eles os cidadãos produtivos mais representativos, ou serão dependentes?” (ILLICH, 1979: 74).

A tese central de Illich é que as "profissões" são tirânicas porque desabilitam, deslegitimam e desvalorizam todas as atividades ou trabalhos que não são profissionalizados. Por isso, os desempregados que ainda não perderam totalmente suas habilidades podem ser úteis e criadores de valores de uso, como na autoconstrução de moradias, por exemplo.

Num breve resumo das idéias desse autor, temos que as mercadorias industrializadas tornam-se o padrão mundial e inabilitam toda a produção de valores de uso que não seja pela via industrial. Cria-se uma cultura de produtos estandardizados que passa a considerar como pobreza tudo que não se encaixa no padrão; então, a única forma de higiene sanitária é o papel higiênico e de iluminação doméstica é a lâmpada e o interruptor. A "pobreza modernizada" é a desqualificação de tudo que foge a padrões mercadológicos. Assim, as mercadorias transformam e, principalmente, criam necessidades que não havia. As profissões deslegitimam outros trabalhos, por exemplo: o médico acaba com os curandeiros, o arquiteto desabilita o construtor autônomo. Enfim, a profissionalização desabilita as atividades que existiam anteriormente à estandardização da mercadoria; assim, a qualidade de uma sociedade depende de que haja desempregados que saibam produzir valores de uso, mesmo não sendo profissionais. O monopólio de atuação profissional acaba com a possibilidade de ações autônomas de produção de valores de uso. O desemprego útil é capacidade de trabalho, de criação que não foi tolhida pelo monopólio industrial.

Ganha força aqui a idéia de que justiça social, para Illich, tem que ser justiça distributiva, no sentido de igualdade de acesso aos produtos e recursos da sociedade e justiça participativa, como autonomia igual para todos na criação de valores de uso.

Neste sentido é preciso que haja liberdade para os cidadãos poderem produzir valores de uso sem que a sociedade sempre transforme esta produção num direito profissional que proíba a prática anterior. Pois, cada novo emprego regulamentado torna ilegal o trabalho anteriormente feito por um não profissional. A profissão fixa o que é bom e distorce “a vontade e a habilidade do homem 'comum' para viver dentro de sua própria medida" (ILLICH, 1979: 71).

Ele defende a "modernização da subsistência" que é a "desescolarização da competição", a "desprofissionalização da medicina" etc. A sociedade precisa reconhecer o direito igual de "todos à ocupação eficaz do desempregado" (ILLICH, 1979: 93). A 
expansão da profissionalização identifica trabalho com emprego assalariado. O trabalho é mais do que o estabelecido pelo mercado profissional. A valorização da ocupação pelo trabalho assalariado deprecia todas as outras formas econômicas, como a doméstica, a camponesa etc. Decorre disto que reivindicar mais emprego - no sentido da profissionalização - é também uma forma de descartar o "desemprego criador". O direito ao desemprego útil contrapõe-se ao ethos profissional: a construção institucional mina a habilidade para a autoconstrução; a medicalização da saúde impede a modernização científica da higiene popular; o diploma escolar e o profissional degradam a situação do autodidata (ILLICH, 1979: 87). Pode-se concluir que, em assentamentos de reforma agrária composto por pessoas oriundas da cidade, encontram-se muitos conhecimentos e habilidades que não foram legitimadas por diplomas, mas que são importantes para a formação do local.

Portanto, no assentamento esses conhecimentos "não-profissionais" podem aflorar e ser trocado com os demais. Então, ver o modo de vida camponês e outras necessidades para a vida no campo como formas que podem ser resgatadas ou aprendidas é a possibilidade e desafio para construir e restituir ações autônomas de produção, o que vai ao encontro do "desemprego criador". É importante enfatizar que a constituição de modos de vida que não sejam capitalistas é um desafio e é um aprendizado; pois, se cairmos em visões sobre uma essência camponesa, acabamos por desqualificar todos aqueles que não se encaixariam nela, como o "individualista" ex-morador de rua.

$* * *$

Procurou-se enfatizar, neste capítulo, como o pensamento moderno tratou camponês e morador de rua de maneira ambígua ou ambivalente, às vezes, oscilando entre produto da sociedade ou da natureza. Para criticar tal perspectiva, foi visto que esse pensamento moderno constitui e individualiza os pobres como tema de estudo e como objeto dos poderes; sendo assim, ciência e regulação social andaram paralelamente. Dado que há essa oscilação para definir camponês e sem teto, é possível questionar a necessidade de haver um caráter essencial do campesinato para ser um assentado. Aliás, o registro não moderno possibilita a contraposição a visões que buscam "essências" camponesas, pois estas limitariam a compreensão das contribuições daqueles que não teriam tal "essência". $\mathrm{O}$ que nos remete a enfocar na potencialidade daqueles que vieram das ruas a possibilidade 
de justiça social, na qualidade do "desemprego criador", a ser realizado nos assentamentos de reforma agrária.

No próximo capítulo, há uma problematização da questão do morador de rua, com análises dos dados populacionais em São Paulo e das alternativas. 


\title{
A vida nas ruas de São Paulo: interpretações, dados e análises
}

\author{
o lixo \\ plásticos voando baixo \\ cacos de uma garrafa \\ pétalas \\ sobre o asfalto \\ aquilo \\ que não mais \\ se considera útil \\ ou propício \\ há um balde \\ naquela lixeira \\ estão nos sacos \\ jogados na esquina \\ caixas de madeira \\ está nos sacos \\ ao lado da cabine \\ telefônica \\ o lixo está contido \\ em outro sacos \\ restos de comida e cigarros \\ no canteiro, sem árvore, \\ lixo consentido \\ agora sob o viaduto \\ onde se confunde \\ com mendigos
}

Régis Bonvicino (2004)

\section{Problematizando o tema}

Parte-se neste capítulo das ambigüidades e ambivalências presentes na caracterização de quem é o morador de rua no Brasil para se mostrar um perfil dessa população na cidade de São Paulo e dialogar com as alternativas existentes.

Ao se estudar as imagens transmitidas pela imprensa sobre moradores de rua, notam-se alguns enfoques recorrentes: "confundi-los" com lixo ou com "pessoas normais"; os homicídios sofridos; morte por hipotermia no inverno ${ }^{1}$. A freqüência destes temas é obscurecida quando ocorrem casos de impacto como os assassinatos em série de moradores de rua na cidade de São Paulo, em agosto de 2003. Ser indistinguível, ser vítima, estar fora dos padrões de civilidade, ser parcialmente atendido pelos serviços públicos, ter direitos, ser desempregado: são movimentos tanto de homogeneizar quanto de diferenciar os 
moradores de rua. Às vezes, eles são tratados como pertencentes a classe trabalhadora, mas em condições de miséria extrema, outras vezes, são diferenciados como abaixo desta classe. Portanto, morrer assassinado ou por causa do frio é comumente noticiado, pois essa parcela "não faz falta para a economia do país".

Pelo tratado no capítulo anterior, a condição de mendicância é interpretada pelos autores do século XIX de diferentes formas como algo que está fora do ritmo de transformações. Haveria nesse tema uma dificuldade de encaixá-lo no registro dos condicionantes sócio-culturais ou nos "impulsos naturais". Neste sentido, pode se dizer que as interpretações sobre o fenômeno o tornaram um "híbrido", de acordo com o estabelecido por Latour (2000), conforme visto na Introdução e no primeiro capítulo. Deste modo, é possível ver nas diferentes abordagens sobre os moradores de rua, tanto do século XIX quanto do XX, a formação de um "quase-objeto", porque mistura natureza e cultura.

Conforme visto com Marx, o "mendigo" moderno era fruto de dois processos: expropriação e legislação. Isto é, os "mendigos" dos séculos XIV ao XVI eram excamponeses que perderam suas terras e migraram para as cidades e, então, foram enquadrados em leis que regulavam suas condutas nesse novo meio social. Por esse segundo aspecto, eles foram rotulados pela legislação que dizia qual atitude era permitida e qual não o era. Como se sabe, o século XIV representou uma reviravolta na questão da mendicância em relação ao auge do período feudal, quando a questão era interpretada pela moral cristã, porque foi o primeiro momento na história ocidental em que a “vagabundagem” passou a ser crime (Cf. STOFFELS, 1977: 29-46).

Diante da perspectiva da lei, análises recentes mostram que o morador de rua só pode perder, isto é, sempre sofre o peso legal. Com a posição mais baixa no espaço social a população de rua está sujeita a maior aplicação de lei, conforme apontado por Black (1998 e 2002). Para o autor, um morador de rua ser agredido pela polícia não é algo ilegal e sim a lei mostrando seu comportamento baseado em distinções sociais, neste caso, assimétricas (BLACK, 1998 e 2002). O autor mostra que nos Estados Unidos recai tanta lei sobre o morador de rua, a começar pela forma como ele é tratado pelos policiais.

Do ponto de vista da sociologia pura, o policial chutando um morador de rua é lei. É uma forma mais severa de lei do que normalmente ocorre em outras localizações do espaço social, mas ainda é lei. O chute em um morador de rua ilustra o que acontece quando alguém ocupa simultaneamente um número de localizações sociais, todas elas atrativas à lei e à punição. Um morador de rua perde status social de todo tipo: é extremamente pobre,

\footnotetext{
${ }^{1}$ Para uma análise das representações sobre morador de rua, ver Justo (1997).
} 
e sua integração social é extremamente baixa. Faltam-lhe posses, dinheiro, emprego, residência na comunidade, e um dependente familiar que lhe apóie. Ele não é associado a uma organização. Não tem respeitabilidade, tem um modo estranho de vida, e pode pertencer a uma minoria cultural. Provavelmente, ele é também um estranho para a maior parte dos policiais. Ele é, em resumo, uma forma de sujeira social. E como um imã social, atrai um estilo de lei altamente penal. Não apenas um morador de rua é mais vulnerável aos procedimentos formais como prisão, processo e condenação; ele também pode ser chutado, levar cacetada e ser, em geral, degradado de um modo raramente visto em outras localizações sociais. (...)

Talvez eu deva elaborar a idéia do chute como lei. Entendo, afinal, que muitas pessoas como advogados e professores de direito diriam que chute por policiais é um violação à lei, e que não pode ser uma instância da lei ao mesmo tempo. Mas pode. Falando sociologicamente, não importa se chutar é ilegal de acordo com a lei escrita. Nem mesmo importa se um caso particular de chute por um policial é tratado como crime e punido (o que é extremamente improvável). O chute ainda é lei - controle social governamental. É uma aplicação da autoridade legal. O oficial é um agente do Estado, e nesse sentido é o próprio Estado que chuta. A implicação pode ser surpreendente: a lei pode ser criminosa (BLACK, 2002: 274).

Esta análise nos faz relativizar a perspectiva de que a luta por direitos civis e a consolidação do Estado democrático de direito no Brasil garantiriam melhores condições para a população de rua.

O estudo de Barak (1992) faz uma análise da condição do sem teto na história recente dos Estados Unidos com enfoque na crescente criminalização dessa condição. O autor mostra que a condição de morador de rua, a partir dos anos 1980, vai ser vítima de maior incidência de leis e políticas que punem a presença e a atitude dos moradores de rua. Porém, estatisticamente a criminalidade cometida por moradores de rua é muito menor do que por não-moradores de rua. Para esse criminologista, os moradores de rua são vítimas da condição de sem teto e da omissão do Estado que deve lhes garantir o direito constitucional a um abrigo. Esse aumento da criminalização está associado à retirada das políticas do Welfare State.

O criminólogo mostra que o primeiro trabalho sociológico nos Estados Unidos da América sobre moradores de rua é de 1923 e consiste num estudo sobre as razões que levam a esta condição e, em 1936, surge um segundo trabalho de referência que aponta para o fato de que uma fatia da população é forçada a ir para albergues porque está destituída de qualquer meio de vida. Barak (1992) prossegue na análise das abordagens 
sobre o tema ao longo das décadas para afirmar que, a partir dos anos 1980, ocorre uma distinção entre um "velho" e um "novo" sem teto marcada pela visão de que pobreza e privação de abrigo são mais sintomas da política econômica do que causas da condição de morador de rua em si. Segundo o autor, há uma construção social do morador de rua que molda a reprodução do problema social.

O posicionamento marxista de Barak permite notar que análise científica e contexto político andam juntos. Assim como, há no estudo a noção de que as estruturas sociais são os determinantes da condição de sem teto. Vejamos outros casos.

Em um número especial sobre homeless da revista norte americana Urban Geography, Hoch (1991) analisa a organização espacial urbana em relação ao caso dos moradores de rua de Chicago. Mostra que as políticas governamentais de reforma urbana do centro da cidade, que acabaram com os quartos de solteiros em hotéis baratos (Singleroom occupancy) dos quarteirões destinados aos "marginalizados", promoveu o fim da sobrevivência digna dessa população. Portanto, o que mudou no perfil do morador de rua dos anos 1950 para os 1980 foi a impossibilidade de poder dormir nesses locais, que o autor considera que serviam como garantia de alguma independência ao sem teto. Esse urbanista mostra que em 1985 havia 2 mil sem teto em Chicago e que as condições de obtenção de renda deles era bem menor do que nos anos 1950. Dear e Gleeson (1991), por sua vez, apresentam um estudo da atitude do público (com base em jornais de Los Angeles e Nova York) em relação aos moradores de rua. Concluem que a situação é paradoxal, pois a população em geral expressa que, por um lado, são necessárias políticas de assistência social aos miseráveis e, por outro, há muito preconceito em relação aos sem teto. Os autores analisam o contexto para mostrar que há um aumento da população de rua decorrente da retirada de investimentos sociais por causa da mudança na política do Welfare State promovida pelo presidente Reagan, a partir do ano de 1988.

Se, por um lado, aparece a questão da lei e do controle social, de outro, os moradores de rua são associados à "natureza", como se pode constatar em estudos sobre as atitudes diante deles. Mais especificamente, a presença do morador de rua provoca na opinião pública um impacto porque há uma exposição de algo do mundo privado, as necessidades fisiológicas. Em seu estudo, Dear e Glenson (1991: 164) mostram que o maior número de registros jornalísticos sobre os impactos na vizinhança da presença de moradores de rua diz respeito à presença de urina e fezes em locais públicos. Porém, a perspectivas de condicionantes "naturais" da condição de morador rua fica explícita nos 
trabalhos de Weiner e Weaver (1974) e de Shnabel (1992), ao tratarem a questão pela psiquiatria e pela neurologia, respectivamente.

Weiner e Weaver (1974) realizaram um estudo quantitativo entre moradores de rua associando o alcoolismo ao aumento da incidência da atividade de pedinte: quando sóbrios, trabalham; quando bêbados, pedem. O foco é: pedinte e alcoolismo como desvios sociais.

Shnabel (1992) apresenta uma mudança nos últimos sessenta anos no perfil da população de rua, com o aumento do número total e da diversidade étnica de pessoas que vivem nas ruas de cidades da Holanda. Coloca que entre $25 \%$ e $35 \%$ dos moradores de rua têm ou tiveram histórico de distúrbios psiquiátricos. Portanto, o autor defende que a psiquiatria deve ter um maior papel de controle social dessa população, que deve ser internada quando necessário.

Ambigüidade ou ambivalência na caracterização manifesta-se também nas denominações diversas: mendigo, morador de rua, sofredor de rua, sem-teto, pedinte, indigente, excluído, andarilho, trecheiro, trabalhador sem teto, catador etc. Esta diversidade de (des)qualificações deve-se, em parte, à diversidade de tipos e situações de viver na rua; e também, a posições políticas que derivam da forma como se concebe o morador de rua. Este é, geralmente, definido pela falta, pela carência absoluta. Ao longo da tese optou-se pela denominação "morador de rua", porque define o grupo por uma condição de moradia em comum. Encontra-se nos trabalhos a posição de que alguns dos sujeitos pesquisados procuravam se diferenciar dos "vagabundos" ou dos "alcoólatras" (STOFFELS, 1977; NASSER, 1996). Essa mesma posição foi encontrada no decorrer do trabalho de campo para a realização desta tese, conforme pode ser visto no quinto capítulo.

Quando se interpreta o morador de rua, as representações podem ser resumidas em: excluídos. No entanto, esta expressão leva-nos a indagações: excluídos de quê, de onde? As respostas mais imediatas dizem que os moradores de rua estão fora do mercado de trabalho, do acesso à moradia, à educação, à saúde etc. Porém, determinada corrente teórica mostra a exclusão e a inclusão como duas partes de um mesmo processo e que somente a lógica dialética dá conta de superar esta dicotomia. O artigo de Luciano Oliveira (1997) aponta para o fato de que o conceito de "exclusão" já havia sido questionado pela crítica à razão dualista ${ }^{2}$, ao estabelecer exclusão/inclusão como um par dialético inerente ao modo de produção capitalista em suas diferentes fases; deste modo, a visão dicotômica do processo de exclusão estaria ultrapassada. O sociólogo argumenta que,

\footnotetext{
${ }^{2}$ Referência ao trabalho do sociólogo Francisco de Oliveira.
} 
contemporaneamente, há excluídos cuja inclusão, possivelmente, nunca acontecerá. Então, propôs que os "excluídos" sejam pensados de um ponto de vista valorativo acerca do que seja um modo de vida humano. Por fim, coloca que o conceito de excluído, mais do que teórica, tem uma razão ética e política porque "interpela sobre a natureza da polis que estamos construindo" (OLIVEIRA, 1997: 60).

De fato, há uma nova fase do modo de produção capitalista decorrente da revolução industrial da microeletrônica. Nesse contexto, tem-se a posição de que o trabalho assalariado chegou ao fim (Cf. GRUPO KRISIS, 1999). A liberação de mão-de-obra provocada pela terceira revolução industrial criou um "lixo" humano que não é mais empregável. Porém, não cabe aqui aprofundar a discussão teórica sobre a crescente massa populacional de não empregáveis e sim apresentar alternativas para a população de rua.

Dentro do raciocínio da dialética entre exclusão e inclusão, Singer (1998) mostra que a terceira revolução industrial, a da microeletrônica, e a globalização provocaram um desemprego "estrutural”. Ações estatais de compensação e, principalmente, a economia solidária (ou auto-emprego) são as alternativas a essa conjuntura. Para o autor, a economia solidária é uma alternativa ao modo de produção capitalista e é o socialismo aqui e agora. Vejamos uma seqüência da argumentação do autor:

Para resolver o problema do desemprego é necessário oferecer à massa dos socialmente excluídos uma oportunidade real de se reinserir na economia por sua própria iniciativa. Esta oportunidade pode ser criada a partir de um novo setor econômico, formado por pequenas empresas e trabalhadores por conta própria, composto por ex-desempregados, que tenha um mercado protegido da competição externa para os seus produtos. Tal condição é indispensável porque os ex-desempregados, como se viu, necessitam de um período de aprendizagem para ganhar eficiência e angariar fregueses. Para garantir-lhes o período de aprendizagem, os próprios participantes do novo setor devem criar um mercado protegido para suas empresas.

Uma maneira de criar o novo setor de reinserção produtiva é fundar uma cooperativa de produção e consumo, à qual se associarão a massa dos sem-trabalho e dos que sobrevivem precariamente com trabalho incerto (...).

O mercado protegido será uma condição necessária mas não suficiente para que o novo setor de economia solidária dê certo. O seu êxito não consistirá somente na mera sobrevivência das empresas e pessoas que o constituem, embora a sobrevivência no tempo já represente a solução para o desemprego, ou seja, a reintegração econômica - e portanto social - dos hoje marginalizados. Mas o objetivo almejado deve ser a criação de uma lógica 'incluidora', ou seja, capacitada e interessada em acolher sem limites novos 
cooperados, e que ofereça a estes uma chance real de trabalhar com autonomia e de ganhar um rendimento suficiente para ter um padrão de vida digno. (...)

Em outras palavras, o ponto de partida da economia solidária é o reconhecimento que $a$ causa maior da debilidade da pequena empresa e do autônomo é o seu isolamento. (...)

Esta forma de luta contra o desemprego tem muitos pontos em comum com a organização de produtores autônomos (e empresas capitalistas coletivas) em sistemas de crédito mútuo e comércio recíproco. O principal deles é a prática da solidariedade em lugar da competição. Na empresa autogerida, a preservação dos postos de trabalho substitui a lucratividade como objetivo máximo. Os trabalhadores-gestores se dispõem a fazer sacrifícios, eventualmente abrindo mão de salários mais elevados, para que todos possam continuar trabalhando. Na empresa capitalista, os empregados competem por promoções, prêmios de produção, lugares de chefia. Na empresa auto ou co-gerida a confiança mútua e a ajuda mútua são vitais para recuperar a competitividade, não há possibilidade de alguns se beneficiarem em detrimento de outros. (SINGER, 1998: 73-138; os grifos são meus).

Além da discussão sobre exclusão/inclusão, a questão se aprofunda ao se verificar que recaem sobre o morador de rua os mecanismos de tutela, como foi exposto por Castel (1978). Vale lembrar que na análise de Castel o dispositivo da tutela recai tanto sobre o "mendigo" quanto sobre a classe trabalhadora como um todo. Mais do que mostrar que essa população é alvo de vigilância, ela é constituída pelos dispositivos de controle social, deduz-se. Num certo sentido, as tentativas das entidades filantrópicas, dos grupos de direitos humanos e de prefeitos em conhecer o perfil populacional alimenta a disputa pela tutela sobre os moradores de rua. O conhecer para controlar insere-se numa gama que vai da repressão a propostas e ações democráticas de luta por direitos.

\section{O espaço comum e as interpretações: conhecer para agir e controlar}

Os estudos brasileiros sobre os moradores de rua tratam dos seguintes temas: viver na rua (são "pedintes" ou "mendigos"); violência; mundo do trabalho e desempregados (são tratados pela literatura como "sem teto" ou "morador de rua").

A população que vive nas ruas é tratada, nos anos 1970 e 1980, pelo termo "mendigo" e as análises mostram que o público, em geral, o distingue do "pedinte", sendo aquele a pessoa que perdeu certos atributos sociais (família e casa), sobrevive nas ruas, não trabalha e apresenta-se sujo e mal-trapilho, enquanto que este possui atributos sociais, mas tem dificuldade para sobreviver e depende da ajuda de terceiros (NEVES, 1983). Neves 
(1983) estuda o fenômeno social da mendicância como forma de reprodução social dos trabalhadores e conclui que é uma "alternativa de vida" para estes.

O viver na e da rua é uma categoria fundamental na análise desta população. Stoffels (1977) chama a atenção sobre aqueles que vivem nas ruas como um habitat total. O espaço "rua" é vivido como um território apropriado. Neste caso, a rua divide-se em três locais distintos: o de sobrevivência, o de repouso e o de convivência grupal. Um dos grupos estudados pela autora vivia numa praça e limitava-se às fronteiras do local de convivência. Isto é, o morador de rua sabia qual era o seu espaço e qual era o do outro, dos vizinhos. Os requisitos do espaço para a permanência de "mendigos" era: isolamento, pouco movimento, proteção contra a repressão, pontos de pedido, locais de repouso e locais de convivência. O público transeunte, como doador de esmolas, é o recurso do "mendigo". Ao mesmo tempo, este estranha aquele quando o estigmatiza de "vagabundo". Assim, "surge uma 'fronteira' no espaço-rua, utilizado como território apropriado e lugar público" (STOFFELS, 1977: 150). A questão central desta autora é a complexidade e especificidade das atividades e da ideologia da mendicância. Ela situa a problemática na apreensão de uma autonomia relativa das atividades e da ideologia dos "mendigos" em relação à ideologia dominante.

A partir dos anos 1990, com um contexto de novas políticas municipais de bemestar social, os trabalhos analisam o perfil da população de rua (VIEIRA et alli, 1994), as formas de atendimento a essas pessoas e as práticas assistenciais em geral, a relação de uso privado do espaço público, as organizações dos moradores de rua e a migração. Os textos de Vieira (1995), Neves (1995) e Montes (1995) dialogam e problematizam as ações de militantes e políticas em relação aos moradores de rua. Enquanto Vieira e Neves tratam do tema pela perspectiva da classe trabalhadora, Montes privilegia a questão da identidade "fragmentada".

Vieira (1995: 43) fala que o morar na rua dá um novo sentido ao uso do espaço público. O que é privado, como comer, beber, dormir etc., torna-se público. O público, enquanto espaço coletivo de circulação, torna-se espaço de morar. Esta subversão de regra faz da ocupação das ruas um fato conflituoso. Neves (1995) destaca nas estratégias de sobrevivência dos moradores de rua o fato de "quanto mais pertences acumulam, quanto melhor se organizam para viver na rua, quanto mais demarcam simbolicamente, através de papelões e plásticos, um espaço para a privacidade ou menos vulnerável ao olhar do curioso, mais incitam a repressão, mais escandalizam os demais usuários do espaço público" (NEVES, 1995: 69). 
Montes (1995) coloca que o discurso recente sobre a população de rua precisa ser problematizado porque se volta, principalmente, para a questão da identidade. Ela mostra que a identidade é um feixe de relações e que o senso comum tem dificuldade de pensar a identidade do morador de rua frente aos outros atores com os quais se defronta na vida da cidade. A pluralidade de discursos construídos pelos grupos que lidam com a população de rua sobre a identidade desta, à medida que ela própria os introjeta, gera uma experiência de fragmentação. Coloca-se, então, a questão da reconstrução da identidade fragmentada do morador de rua, justamente porque identidade é o que dá sentido de unidade. Este comentário de Montes permite visualizar as duas dimensões da questão da mendicância: as análises sobre a população em geral e sobre as pessoas em si.

Os trabalhos de Sérgio Martins (1995), Nasser (1996) e Maria de Fátima Martins $(2001)^{3}$ estudam a migração e as políticas sociais e os perfis de moradores de rua e de albergados, como formas de reprodução dos trabalhadores. Há também o trabalho de Barros (2004), que analisa a experiência da vida nas ruas e da constituição das redes de atendimento, sendo que chega a estudar o assentamento D. Tomás Balduíno, organizado pelo MST, com ex-moradores de rua. Esta autora faz uma análise dos nomes como são tratados so moradores de rua e um histórico das polítcas sociais dos anos 1990. Dentre esses trabalhos, o estudo recente de Martins (2001) vai ao encontro desta tese porque aponta para a necessidade de se compreender a migração num novo contexto em que conceitos e noções como o de "exército industrial de reserva" e de "mobilidade de força de trabalho pelo capital" são insuficientes porque os "excluídos" não cabem mais nestas noções, pois o modo de produção capitalista está numa fase de aumento da produtividade sem geração de empregos. Para essa autora, o homem que está fora da relação trabalhocapital é uma figura "fanstasmagórica", inclusive para o pensamento. Por isso, ela coloca que “(...) através dos moradores de rua e com eles é possível redefinir a compreensão da rua, da experiência urbana que significa e, mais ainda, de seu sentido na história"

\footnotetext{
${ }^{3}$ Há também a interessante tese de Ferraz (1998) que trata indiretamente do tema do morador de rua ao analisar o imaginário popular em relação ao "louco" de rua.

A loucura também é um grande tema associado à imagem do morador de rua, mas, não há espaço para discuti-lo aqui. Então, valem algumas referências, além da tese de Ferraz (1998). Para um posicionamento conceitual diante da questão, ver a História da Loucura, de Foucault, em que o autor mostra como o louco toma o lugar do leproso nas políticas de internamento e, então, analisa como a loucura vai se constituir como o Outro da razão moderna. Sobre "loucos", "profetas" ou "artistas" que vivem nas ruas, há uma série de reportagens da grande impressa, sendo que um dos casos mais emblemáticos e conhecidos é o de Arthur Bispo do Rosário, um ex-marinheiro que teria tido um surto psicótico e saiu vagando pelas ruas até ser internado na colônia Juliano Moreira, no Rio de Janeiro. Durante o período de internação produziu uma série de trabalhos artísticos que foram expostos em museus do Brasil e da Europa. Há um filme e um livro sobre ele. Sobre os "loucos" das ruas de S. Paulo, ver o vídeo de Chnaiderman (1994).
} 
(MARTINS, 2001: 116). Essa geógrafa enfoca as redes sociais ${ }^{4}$ dos moradores de rua, passando por uma geografia da assistência, para mostrar que a condição desta população leva a dar sentido a uma articulação em rede, uma vez que nas ruas as tramas são frágeis e os laços tênues (MARTINS, 2001: 187-193). Chama a atenção a contribuição de Barros (2004) por analisar a população de rua pelo registro de questionar a modernização brasileira, interpretando a insibilidade desse tipo de pobreza como uma forma de permante exceção. Para a autora, a população rua é um meio para compreender os processos de modernização da sociedade brasileira. Neste sentido, o texto de Barros está próximo dos questionamentos expostos nesta tese.

\section{Histórico das políticas no Brasil em relação à população pobre}

Pinheiro (1981) mostra que desde o início da Primeira República existe a perseguição às “classes subalternas". Naquela época a "vagabundagem”, entre outros, estava na lista dos crimes comuns (PINHEIRO, 1981: 36). Nesse texto, o autor aponta uma tradição de violência física e ilegítima por parte do Estado, tanto nos regimes autoritários, quanto nos mais democráticos. Há uma repressão generalizada em relação às "classes subalternas" e uma repressão qualificada em relação às "classes trabalhadoras". Essa institucionalização da violência pelo Estado é, segundo o autor, uma política deliberada de controle social das classes subalternas.

Observa-se com Adorno (1990) que o processo de isolamento dos "desajustados" ocorre no Brasil entre 1880 e 1920. Período esse justamente de transição do trabalho escravo para o trabalho livre. Com o fim da ordem escravocrata, os pobres ocupam o espaço urbano. Temos uma série de trabalhadores pauperizados e expropriados e a eles juntam-se os imigrantes europeus. Estes enquadram-se nas mais diversas atividades para garantir a sobrevivência.

Todos esses acima foram os clientes preferenciais da filantropia, porque criavam o obstáculo para a constituição do trabalhador dócil. No período estudado pelo autor, houve um agravamento da criminalidade, cuja violência era a norma para a resolução dos conflitos sociais. Outra referência constante era em relação aos "menores vadios", os mendigos e as prostitutas, "sujeiras" a serem saneadas. Por isso, discutia-se a missão preventiva do Estado para minimizar a mendicância e o abandono de crianças. Junto com os loucos, que vagavam pelas ruas, toda uma "escória” formada por ladrões, prostitutas,

\footnotetext{
${ }^{4}$ A autora parte da conhecida definição de "rede" que Raffestin (1993) empresta de Serres. Porém, ela acrescenta a perspectiva habermasiana da teoria da ação comunicativa.
} 
bêbados, mendigos etc., constituintes das "classes perigosas", deram trabalho para os alienistas. Estes tinham entre seus objetivos imediatos a moralização do espaço público, coloca o sociólogo.

Desenhou-se assim todo um esforço classificatório voltado para distinguir e estabelecer fronteiras entre loucos e criminosos, vagabundos e pobres, definindo-se lugares apropriados de segregação ou de "cura" que possibilitassem maior refinamento das operações de controle e de vigilância médica (ADORNO, 1990: 16).

A filantropia entra para proteger a população urbana trabalhadora das adversidades da pobreza. Essa "gestão filantrópica da pobreza urbana", para concluir, só foi possível com a invenção do estatuto da tutela.

Dando seqüência ao movimento histórico, passamos para as décadas de 1950, 60, 70 e começo de 80. Sposati (1988), ao analisar os serviços municipais de assistência social e seu aparato burocrático do período, apresenta a tese de que a gestão da pobreza por parte do Estado restringiu-se a intervenções ou atendimentos pontuais sem ir à raiz, caracterizando uma relativa omissão ao particularizar o problema.

Dentro desse processo histórico, na virada dos anos 1980 para os 1990 ocorreu uma mudança em relação à questão do morador de rua (Cf. COSTA, 1989; OLIVEIRA e VICENTE, 1989). Foi um movimento tanto de busca da cidadania da população de rua, com base na participação direta dos mesmos, quanto de encontrar alternativas para sair da condição de morar nas ruas. Os trabalhos da Pastoral dos Sofredores de Rua, da Fraternidade Povo da Rua (tratada na Introdução) e de outras entidades civis e/ou religiosas deram um outro enfoque político para o tema que não é mais o da filantropia (Cf. ROSA, 1995).

\section{As políticas e as ações civis recentes em relação aos moradores de rua ${ }^{5}$}

Por um lado, a política de segregação dos moradores de rua na cidade de São Paulo teve um auge com uma lei de cercamento das praças públicas pelo governo municipal, na gestão do falecido Jânio Quadros (PTB - Partido Trabalhista Brasileiro), de 1985 a 1988. A partir do ano de 1994, setores da sociedade procuraram evitar a presença dos "mendigos" com a construção de prédios sem marquise, com funcionário de loja jogando óleo queimado na calçada em frente, com a prefeitura realizando operação "anti-mendigo" - como a colocação de grades em árvores de praças. Estas atitudes tiveram o apoio do

\footnotetext{
${ }^{5}$ Para uma análise das políticas sociais em relação à população de rua a partir dos anos 1990, que problematiza a noção de polítca envolvida, ver Barros (2004).
} 
Administrador Regional da Sé, na época (Cf. FOLHA DE S. PAULO, 04/09/94 e 12/09/94).

Por outro lado, no mesmo ano 1994 ocorreu, no dia 10 de maio, na Câmara Municipal de São Paulo uma celebração do quarto ano de luta da população de rua. Estavam presentes moradores de rua em geral, membros de centros comunitários e de direitos humanos (que são moradores de rua), membros da Pastoral do Povo da Rua, Secretários municipais, sindicalistas e vereadores. Nessa oportunidade, a vereadora Aldaísa Sposati, do PT, entregou ao presidente da Câmara seu projeto de lei (No. 207/94) de uma política de atenção à população de rua. Em seu depoimento, a vereadora disse que quando era Secretária Municipal das Administrações Regionais foi procurada por moradores de ruas e Irmãs católicas para reivindicar o direito de recolher o papel das ruas porque viviam disso $^{6}$. Em 1997 foi aprovada lei municipal (No. 12.316/97) que estabelece como dever do poder público municipal da cidade de São Paulo manter serviços e programas de atenção à população de rua garantindo "padrões éticos de dignidade".

Ao longo dos anos 1990, os moradores de rua passam a ser mais tematizados e viram alvo da preocupação de algumas instituições. Destacam-se alguns eventos: a Campanha da Fraternidade da Conferência Nacional dos Bispos do Brasil (CNBB), de 1995, teve como tema "os excluídos"; o curso de jornalismo de uma faculdade privada começou a produzir um jornal sobre essas pessoas, para ser vendido por meninos de rua. Outra iniciativa foi a realização do Mapa da Exclusão/Inclusão Social da Cidade de São Paulo, em 1995, pelo Núcleo de Seguridade e Assistência Social da PUC/SP em conjunto com outras entidades, que se refere inclusive a homeless. Dois Seminários Nacionais sobre População de Rua foram realizados, um em 1992 em São Paulo, e outro, em 1995, em Belo Horizonte/MG. Vale lembrar de O Trecheiro, jornal publicado pela Rede Rua de Comunicação desde 1990 e da organização da primeira cooperativa dos catadores autônomos de papel, fundada em 1989. Outras duas iniciativas que se destacam na forma de lidar com a população em situação de rua são a ONG Minha Rua Minha Casa ${ }^{7}$ e o Projeto Boracéia, da gestão municipal de Marta Suplicy (PT), de 2001 a 2004, porque envolvem os moradores de rua na gestão.

Desse breve relato, nota-se que os distintos setores da sociedade e do Estado defendem diferentes posições sobre quem pode, ou não, ficar nas ruas. As políticas e as

\footnotetext{
${ }^{6}$ Gabinete da vereadora A. Sposati - Câmara Municipal de São Paulo. "10 de maio de 1994. 4o. Ano de Luta da População de Rua”. Impresso no serviço gráfico da CMSP, p. 12.

${ }^{7}$ Ver "website": www.minhacasaminharua.com.br
} 
ações civis variam de medidas repressivas e excludentes às organizações que envolvem os moradores de rua na gestão. Essa variação é decorrente das posições políticas dos setores sociais envolvidos, seja de liberais, de conservadores ou de socialistas progressistas. Apresentam-se então os contornos da disputa pela tutela: a ciência, os militantes, a assistência social, o Estado estabelecem o perfil do morador de rua e as políticas de bemestar social, que vão da segregação às formas que abrem a possibilidade para a emancipação da condição de tutelados. Portanto, a questão é como sair da tutela.

\section{O perfil do morador de rua em São Paulo}

Antes de apresentar dados sobre a população de rua na cidade de São Paulo, vale ressaltar que as contagens dos moradores de rua são difíceis de serem feitas devido à possibilidade de não cobrir todo o universo e ao risco de contar mais de uma vez a mesma pessoa (VIEIRA et alli, 1994). Portanto, a contagem não se propõe apresentar números definitivos. O primeiro censo de moradores de rua da cidade de São Paulo teve dois eixos básicos:

conhecimento da dimensão, das características, das formas de sobrevivência e da trajetória da população de rua, entendida como a que sobrevive da rua, utilizando-a circunstancialmente ou de forma permanente como moradia; avaliação crítica de algumas formas de atendimento no âmbito das ações públicas e privadas, entendendo-as como ação intencional de instituições e grupos voltada especificamente para esta população (VIEIRA et alli, 1994: 14).

De acordo com o primeiro censo realizado pela Secretaria Municipal da Família e do Bem-Estar Social em 1991, havia 3392 moradores de rua na cidade (VIEIRA et alli, 1994). Do total de pessoas que passaram pelas instituições (para o perfil optaram por questionários em: abrigo, casa de convivência e albergue), 90\% são do sexo masculino e $10 \%$, do feminino. Destes, aproximadamente $65 \%$ têm menos de 40 anos. O levantamento constatou 329 pontos pela cidade onde as pessoas dormem, sendo que $70 \%$ destes pontos localizam-se nos distritos da Liberdade, Bela Vista e Sé. O levantamento apontou como segmento mais significativo os homens, em grupos ou sozinhos. Destacou, também, a heterogeneidade da população, composta por famílias, homens e mulheres sós, crianças e adolescentes. Dos moradores de rua que foram contatados em albergues, $46 \%$ possuíam trabalho até um ano antes. Quanto à origem da população que frequienta abrigo, casa de convivência e albergue, apenas $13 \%, 14 \%$ e $10 \%$, respectivamente, são da cidade de S. 
Paulo, sendo que os demais são do interior de São Paulo ou de outros estados da federação (VIEIRA et alli, 1994: 71).

Pelos dados apontados, nota-se a maior concentração de moradores de rua nas regiões centrais da cidade. Uma das interpretações possíveis para isto é a proximidade a locais para a garantia da sobrevivência, como a obtenção de alimentação gratuita (VIEIRA et alli, 1994: 50). Nesses locais concentram-se pontos comerciais que ficam vazios à noite.

O número de moradores de rua cresceu em 1994. A Secretaria Municipal da Família e do Bem-Estar Social, na sua segunda contagem, chegou a um universo de 4549 indivíduos. A grande maioria deste número continuou sendo do sexo masculino.

Em 1996, o perfil da população de rua não se alterou, apenas os números totais. Continua sendo o homem jovem, do total, quase $70 \%$ estão entre 18 e 44 anos. Da totalidade, $59 \%$ são homens adultos, $15 \%$ mulheres adultas. Nesse terceiro censo realizado pela Secretaria Municipal da Família do Bem-Estar Social, contabilizaram-se 5334 pessoas morando nas ruas. O destaque fica com as regiões Sé e Lapa com aproximadamente 78\% do total computado de moradores de rua da cidade (Cf. FOLHA DE S. PAULO, 13/12/96).

Em 2000, estimavam-se 8.706 moradores de rua. Segundo estudo da FIPE/USP (Fundação Instituto de Pesquisas Econômicas da Universidade de São Paulo) realizado para a Secretaria Municipal da Família do Bem-Estar Social, 37,7\% do total, ou seja, 3018 moradores de rua vivem da coleta de material reciclável (Cf. FOLHA DE S. PAULO 20/05/2001, p. C-1). O perfil seguiu os anteriores: cerca de $85 \%$ da população é do sexo masculino e com idade média de 40 anos (62\% estão no intervalo entre 26 e 45 anos). Quanto à origem, 48,4\% são da região sudeste, 42,1\% da região nordeste e 9,5\% são das demais regiões. Os migrantes são a grande maioria daqueles que pernoitam nas ruas, com $81 \%$, sendo que o estado com maior incidência de origem é São Paulo, com 34,9\%. A maioria, 56\%, vive só. Entre as atividades exercidas, 48,6\% são catadores e os demais encaixam-se como guardador de carros, vendedor, carregador, vigia e outras ocupações.

Em 2003, mais um censo foi realizado pela FIPE para a Secretaria Municipal de Bem-Estar Social e apontou para 10.394 pessoas em situação de rua. Aumentou também o atendimento a essa população pela Prefeitura devido a uma maior oferta de vagas em albergues. Sposati (2003) aponta para o fato de se estimar que nas metrópoles mundiais há cerca de $1 \%$ da população em situação de rua, como ocorre com a cidade de São Paulo.

Os números não revelam um ponto comum na caracterização do morador de rua: ser "trecheiro". Percorrer trechos da cidade é um dos meios de sobrevivência. Vão atrás de 
abrigos, de lugares para o pernoite, de locais que oferecem comida ou, simplesmente, fogem das "pertubações" da polícia militar.

\section{Quadro 1 - Variação do número de moradores de rua por ano}

\section{São Paulo}

1991- 2003

\begin{tabular}{|r|r|r|r|r|}
\hline $1991 *$ & $1994 *$ & $1996^{*}$ & $2000^{* *}$ & $2003^{* *}$ \\
\hline $\mathbf{3 . 3 9 2}$ & $\mathbf{4 . 5 4 9}$ & $\mathbf{5 . 3 3 4}$ & $\mathbf{8 . 7 0 6}$ & $\mathbf{1 0 . 3 9 4}$ \\
\hline
\end{tabular}

Fontes: * Sec. Mun. de Bem Estar Social

**Levantamento da Fund. Instituto de Pesquisas Econômicas para Sec. Mun. de Bem Estar Social

O quadro acima sintetiza os números totais expostos ao longo deste item. Com ele, pode-se visualizar o crescimento do número de moradores de rua em São Paulo, que em treze anos aumentou em mais de três vezes. Vale comparar com as taxas de desemprego do mesmo período na região metropolitana de São Paulo. Não é possível afirmar que o desemprego é um determinante da condição de morador de rua, porém, é um dos fatores condicionantes. O quadro 2, a seguir, mostra o aumento crescente da porcentagem de desempregados, que no mesmo período subiu oito pontos percentuais. Outro indicativo das condições sócio-econômicas da população sem teto, num sentido amplo, são os dados sobre condições habitacionais. Segundo a pesquisa de condições de vida, realizada pela fundação SEADE (Sistema Estadual de Análise de Dados Estatísticos), em relação às condições de habitação, o percentual de barracos isolados e favelas na Região Metropolitana de São Paulo aumentou de 6,2\%, em 1994, para 9,1\%, em 1998; já a proporção de cortiços manteve-se relativamente estabilizada no período, chegando a 5,0\%, em 1998.

Quadro 2 - Variação percentual na taxa de desemprego por ano Região Metropolitana de São Paulo

1991- 2003

\begin{tabular}{|l|l|l|l|l|}
\hline 1991 & 1994 & 1996 & 2000 & 2003 \\
\hline $\mathbf{1 1 , 7}$ & $\mathbf{1 4 , 2}$ & $\mathbf{1 5 , 1}$ & $\mathbf{1 7 , 6}$ & $\mathbf{1 9 , 9}$ \\
\hline
\end{tabular}

Fonte: Convênio SEADE - DIEESE. Pesquisa de Emprego e Desemprego.

Para efeitos comparativos com os números de moradores de rua na cidade de São Paulo, temos que no município do Rio de Janeiro uma pesquisa feita pela UERJ 
(Universidade do Estado do Rio de Janeiro) revelou que no ano de 1999 havia 3535 sem teto, sendo que $45 \%$ tinham carteira de trabalho (Cf. CORREIO BRASILIENSE, 12/11/2000). Em Belo Horizonte/MG, havia 916 moradores de rua em 1996, quando foi realizado o primeiro censo dessa população e, 2001, estimava-se a existência de 1200 pessoas nessa condição (MARTINS, 2001). Estima-se que há em todos os Estados Unidos da América cerca de 300 mil homeless e este número pode chegar a 3 milhões, segundo Barak (1992: 4). Em Nova York/EUA, em 1998, dormiam por noite em abrigos mais de 7.000 pessoas e estimava-se cerca de 25 mil sem teto pela cidade (Cf. FOLHA DE S.PAULO, 13/08/98, p. A-15). Em 2004, havia mais de 36 mil pessoas dormindo em abrigos por noite (Cf. FOLHA DE S. PAULO, 12/07/04, p. A-10). Na Grã-Bretanha, estima-se cerca de 500 mil moradores de rua, segundo Smith (1994: 273-4).

Os números têm dois papéis: mostrar que se parte de uma realidade baseada em pesquisas empíricas que constituem o perfil da população alvo e poder comparar com as possibilidades das alternativas.

\section{Alternativas sociais: MST, MTST e Cooperativas}

Posto que a situação da população de rua é de tutela e que há uma disputa por (re)definir qual tutela, a "alternativa" para esta população só pode ser pensada como emancipação da condição de tutelado, como possibilidade de ela encontrar formas autogeridas de meios de vida e de geração de renda.

Das alternativas nesse sentido, há o MST, o Movimento dos Trabalhadores Sem Teto (MTST) e as cooperativas autogeridas de catadores de materiais recicláveis. Dado seus objetivos como organização, o MST representa também aqueles que não têm um modo de vida camponês. Nesse sentido não haveria contradições para o Movimento em lidar com pessoas que nunca viveram na terra, como por exemplo, o ex-jornalista e estudante de Ciências Sociais que se mudou para o assentamento Nova Canudos ${ }^{8}$, no município de Iaras/SP (Cf. JORNAL DO CAMPUS, 10/10/2000). No entanto, seria e é um desafio. O MST pretende abarcar também aqueles destituídos de qualquer "modo de vida" e ser um caminho para construir uma sociedade socialista. Como tratado na Introdução, há uma prática do MST de levar pessoas que vivem em situação liminar de miséria nos grandes centros urbanos para acampamentos e assentamentos de reforma agrária.

\footnotetext{
${ }^{8}$ Sobre o assentamento Nova Canudos, em Iaras/SP, ver Iha (2001) e Feliciano (2003).
} 
A hipótese de como o MST pode ser uma alternativa solidária para os moradores de rua será trabalhada no capítulo cinco. Então, cabe agora apresentar outras duas alternativas que até o momento constam da trajetória dos moradores de rua.

Cooperativas de catadores de papel e outros materiais recicláveis: eis uma alternativa solidária para os moradores de rua não só de S. Paulo, mas de Porto Alegre, Curitiba, Belo Horizonte e Rio de Janeiro. Na cidade de S. Paulo há mais de 20 cooperativas de catadores de papel. O mercado de lixo reciclável em S. Paulo estava estimado em R \$ 300 milhões, em 2001. Além dos moradores de rua de S. Paulo, o Fórum Lixo e Cidadania - reunião de ONGs (Organizações Não-Governamentais) que atuam no ramo - estimava que cerca de 17 mil pessoas sobreviviam ou complementavam seu orçamento da coleta de material reciclável, no estado de São Paulo (Cf. FOLHA DE S. PAULO, 20/05/2001, p. C-1). Segundo Conceição (2003: 32), estima-se em 300 mil o número de pessoas vivendo de catadores de lixo no Brasil, sendo que dois terços localizam-se no estado de São Paulo ${ }^{9}$.

As cooperativas de catadores lutaram anos pelo reconhecimento da profissão de “catador" pelo INSS (Instituto Nacional de Seguro Social), para ter direitos, maior dignidade e reconhecimento social. Esta foi a principal pauta do $1^{\circ}$. Congresso Nacional dos Catadores, em junho de 2001 em Brasília. É permitido ao membro de uma cooperativa de catadores cadastrar-se como contribuinte individual autônomo junto ao INSS.

A formação de cooperativas de catadores de materiais recicláveis como alternativa de economia solidária também está presente em países como a Colômbia e a Índia, por exemplo. Rodríguez (2002) realizou uma pesquisa-ação junto a uma cooperativa de recicladores de lixo de Bogotá, Colômbia, na perspectiva de que esse tipo de cooperativa tem um potencial emancipador. Ele mostra que, no final dos anos 1990, havia naquele país cerca de 300 mil pessoas vivendo da coleta e recuperação de materiais recicláveis nas cidades, o que correspondia a $1 \%$ da população nacional. Na mesma época, havia em Bogotá 94 cooperativas de recicladores. Uma das deduções do autor é que as cooperativas são relativamente independentes umas das outras e que elas deveriam se integrar numa rede de ajuda mútua para fortalecimento política e econômico (RODRÍGUEZ, 2002: 358).

Além de entrar para o MST ou de formar cooperativas de catadores de material reciclável, outra alternativa surgiu na segunda metade dos anos 1990. Em agosto de 2001,

\footnotetext{
${ }^{9}$ O trabalho de Conceição (2003) chama a atenção para o fato de algumas cooperativas de catadores de material reciclável recriarem a relação patrão-empregado, descaracterizando-as como economia solidária. O
} 
o MTST do Rio de Janeiro ganhou destaque na mídia ao promover a ida de seus membros a um Shopping Center e a um supermercado: os "redutos da classe média foram invadidos", noticiou a imprensa. Segundo Iha (2001), o MST constituiu o MTST, por meio de grupos internos do Movimento, como o "Consulta Popular" que propôs a união das lutas campo-cidade.

O MTST nasceu em Campinas/SP e seguiu para o Rio de Janeiro em 1997, onde promoveu dois acampamentos no ano de 2000. Além de Campinas, o MTST também começou a atuar em São Paulo, Sorocaba, Guarulhos, Osasco, Jandira, Itapevi e na região do ABC, entre outras. De forma independente do trabalho da Fraternidade Povo de Rua, mas com alguns militantes em comum, o MTST cadastrou mais de 2200 pessoas que vivem nas ruas de São Paulo e que querem ir para algum assentamento, em 2001. Desse total, cerca de 500 acamparam, em 7/09/2001, num terreno à beira de rodovia Presidente Dutra, no município de Arujá, por alguns meses. Este acampamento foi organizado pelo MTST e pelo MST. Posteriormente, os acampados conseguiram ser assentados num terreno em Franco da Rocha, é o assentamento D. Tomás Balduíno. Além deste acampamento, há outro em Guarulhos com cerca de 4000 pessoas, o Anita Garibaldi.

A diferença entre MST e MTST é que este último é para moradia e não para produção agrícola, enquanto que o primeiro tem o caráter de reforma agrária. O MTST promove ocupações em área onde não prevalece o módulo rural; as pessoas conseguem moradia e podem ter uma horta. Para o MST interessa assentar as famílias em lotes onde possam produzir excedentes.

\section{$* * *$}

Percorreu-se a trilha de como conhecer, controlar e propiciar saídas aos moradores de rua. No Brasil, até os anos 1970 era quase inexistente a bibliografia sobre moradores de rua e, nos anos 1990, houve uma multiplicação dessa produção. Distinguir o "pobre trabalhador" do "miserável incapacitado" perpassa os trabalhos de acadêmicos, jornalistas, militantes e políticos. Assim como há um movimento de fazer essa distinção e colocar a responsabilidade pelo aumento da quantidade de moradores de rua na estrutura social, há o andar contrário de homogeneizar o poço dos "excluídos". Pode-se dizer que as condições sócio-econômicas, como o desemprego, propiciam um aumento de moradores de rua; 
porém, há múltiplos fatores envolvidos nesta questão. Há uma variedade de perfis de sem teto em que alguns estão dispostos a alternativas, mas outros estão num caminho "sem volta". Portanto, a diferenciação de perfis serve para mostrar que cada um deve ter uma atenção distinta.

Estamos longe de compreender os dramas humanos, as angústias existenciais, que podem levar à ruptura com os padrões de civilidade para se viver como um farrapo. Vamos procurar explicações na sociedade e, às vezes, na natureza. No entanto, o morador de rua nos possibilita pensar as diferentes formas de sociedades e de "naturezas" humanas.

Dados os números da cidade de São Paulo tanto de pessoas vivendo nas ruas e em albergues quanto das possibilidades de alternativas, a ida para o campo ainda é um fresta: permite passar, mas é estreita. Além de ser uma fresta, a ida, ou volta, para a terra ainda não se consolidou como economia solidária no caso do assentamento estudado. Como destacado por Maria de Fátima Martins (2001) e por Barros (2004), os moradores de rua dependem das redes sociais. Assim, como será tratado no capítulo cinco, as redes dos exmoradores de rua são fundamentais para os fluxos de comunicação e de recursos entre eles e a sociedade como um todo. No próximo capítulo, dialogar-se-á com os trabalhos sobre assentamentos de reforma agrária organizados pelo MST. 


\section{Controvérsias na ciência: geografia da produção acadêmica sobre assentamentos}

Este capítulo tem por objetivo dialogar com a literatura acadêmica sobre as experiências de assentamentos de reforma agrária promovidos pelo MST, ou por outras organizações de luta pela terra. Alguns textos ultrapassam o recorte assentamento organizado pelo MST e são analisados pelas contribuições que trazem para os temas estudados.

Visa-se, num primeiro momento, fazer um levantamento crítico da produção acadêmica mostrando as contribuições gerais e específicas de interesse direto para esta pesquisa, os avanços e limitações e as questões metodológicas implicadas nos estudos feitos. Trata-se dos principais temas e questões estudados pelos pares, agrupando os trabalhos nos seguintes recortes: territorialidade, conflitos sociais internos, ethos camponês, cooperativas e gestão (ou organização) interna. Destacam-se as etapas por que passam os assentamentos, no sentido da união ou da desunião, num segundo momento. Num terceiro momento, volta-se para as generalizações apontadas pela parcela da literatura exposta que procura uma sistematização teórica sobre o papel liderado pelo MST na construção de outros modos de vida e de produção.

Como será visto no primeiro item, o enfoque principal dos trabalhos de geografia está no território camponês em oposição ao território do capital. Por isso, procura-se interpretar o território camponês, buscando-se compreender o que representa esse local. A fração de território conquistado pelos camponeses remete a duas questões: o problema dos conflitos sociais e da heterogeneidade nos assentamentos e o debate sobre a construção de um projeto emancipatório camponês; isto é, como construir e consolidar um modo de vida e de produção alternativo ao capitalista, apesar de estar inserido neste. A heterogeneidade nos assentamentos está ligada aos conflitos sociais internos, basicamente à polarização "individualistas"" e "coletivistas", na linguagem do MST que contrapõe a produção familiar no lote à produção coletiva. O ponto a ser defendido, por último, é que não basta apontar que a desapropriação significa formar um território não-capitalista, mas que é

\footnotetext{
${ }^{1}$ Os termos "individualista" ou "individual" aparecem entre aspas porque, na grande maioria das vezes, não quer dizer o indivíduo sozinho, mas com a sua família.
} 
preciso construir nesse local formas de gestão democrática da vida pública e que essa gestão é passível de aprendizado independentemente do chamado "grau de campesinidade", conforme definido por Woortamnn (1990).

\section{Temas e questões presentes nos trabalhos sobre assentamentos}

Basicamente, foram selecionados quatro grupos de temas de interesse para a pesquisa que aparecem nos trabalhos dos pares. São eles: território e territorialização; conflitos sociais internos e externos ao assentamento (principalmente entre as propostas de coletivização e o "individualismo" camponês); ethos camponês (e condições de permanência no assentamento); cooperativismo, gestão, organização e sociabilidade nos assentamentos. Há tanto trabalhos que estudam especificamente um destes temas quanto outros em que se pode encontrar aspectos de dois ou mais temas. Esse recorte analítico está diretamente relacionado com as minhas duas hipóteses de pesquisa e não possui uma pretensão de realizar uma classificação geral para os trabalhos sobre o $\mathrm{MST}^{2}$. Os temas "território" e "ethos camponês" estão conectados à primeira hipótese (como o MST pode ser alternativa para os moradores de rua), o tema "conflitos sociais" relaciona-se à segunda hipótese (como é possível uma gestão pública dos conflitos sociais no interior do assentamento) e o tema "cooperativismo/gestão", direta ou indiretamente, relaciona-se às duas.

\section{Território camponês versus território do capital}

$\mathrm{Na}$ última década ${ }^{3}$ consolidou-se uma linha de produção acadêmica sobre o campesinato na área de geografia, dentro de uma perspectiva analítica específica. São teses

e dissertações que interpretam os assentamentos de reforma agrária como frações do território camponês (FERNANDES, 1996 e 1999; SIMONETTI, 1999; MARQUES, 2000; BOMBARDI, 2001; MITIDIERO, 2002; FELICIANO, 2003; ALMEIDA, 2003; FABRINI, 2003; GONÇALVES, 2004). Esses textos partem da definição de território feita por Raffestin (1993), analizada na Introdução desta tese, e a maioria dos autores segue a apropriação desta definição feita por Ariovaldo Umbelino de Oliveira, ao longo de livros e

\footnotetext{
${ }^{2}$ Para uma classificação dos trabalhos sobre o MST, ver Navarro (2002: 194, nota 6).

${ }^{3}$ Feliciano (2003) mostra que na década de 1990 houve uma "explosão" de dissertações e teses em geografia agrária na USP. De 1946, quando foi defendida a primeira tese nessa área, a 2001 foram feitos 142 trabalhos de pós-graduação sobre o campo brasileiro, sendo que a maioria destes concentra-se nos anos 1990.
} 
artigos, de que "território" é resultado da apropriação que o homem faz do "espaço"; portanto, território e espaço são fundamentalmente diferentes, este antecede aquele. A concepção de Oliveira está sistematizada da seguinte forma: ao possibilitar o assentamento, o movimento territorializa-se, o que abre a possibilidade para o território da liberdade e dos sonhos. Nas palavras do autor, em sua tese de livre docência (1997):

Desvendar o território pode e deve ser uma perspectiva científica para a geografia.

Por isso insistimos: temos que aprofundar a diferença que nos move frente a essa luta de cunho teórico, e por isso reafirmamos que o território não pode ser entendido como equivalente, como igual ao espaço, como propõem muitos geógrafos. Nesse caminho, torna-se fundamental compreender que o espaço é uma propriedade que o território possui e desenvolve. Por isso, é anterior ao território. O território, por sua vez, é um espaço transformado pelo trabalho, é portanto, uma produção humana, logo espaço de luta, de luta de classes ou frações de classes (OLIVEIRA, 1997: 9).

Seguindo essa orientação, os trabalhos de Fernandes (1996; 1999) tornaram-se referência sobre o processo de formação e territorialização do MST, primeiro em São Paulo e, posteriormente (1999), para todo o Brasil, durante o período 1979-1999. Esses trabalhos mapeiam os conflitos agrários que originaram o MST. A sistematização dessas lutas é, em si, uma contribuição desses textos, além disso, o autor esmiúça a organização interna do MST. Aliás, é importante destacar que ele trata o MST como uma "organização" e não simplesmente como um movimento social. Com o trabalho de Fernandes, os termos "territorialização" e "espacialização" da luta foram incorporados na linguagem do MST.

A territorialização é a conquista de território, através da ocupação e, posteriormente, da desapropriação. As frações de território que o MST obtém do território do capital são denominadas, pelo autor, de territorialização. Já a espacialização do Movimento é a ação de reprodução das experiências de luta, é a reconstrução da socialização política. A espacialização da luta representa uma "ampliação da consciência

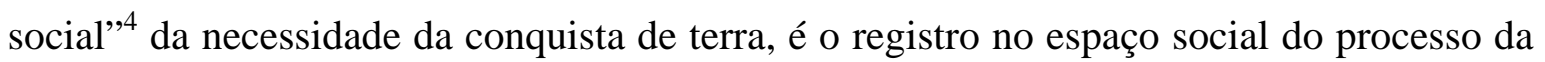
luta. O fato de o MST ter como objetivos a territorialização e a espacialização da luta pela terra é o que o diferencia dos demais movimentos sociais isolados (FERNANDES, 1996: 135-8). Em resumo, o autor enfoca a territorialização do não-capitalismo (conquista de território pertencente ao capital) através das ocupações e a espacialização da luta através da conscientização.

\footnotetext{
${ }^{4}$ Almeida (2003) utiliza a nação de habitus de classe camponesa para se contrapor ao discurso do MST de “ampliação da consciência”, incorporado acriticamente por Fernandes (1996).
} 
Dialogando com o texto de Fernandes (1999), Marques (2000) analisa a organização social e a forma de espacialização dos trabalhadores assentados em Retiro e Retiro Velho, em Goiás Velho/GO. Enfoca o conflito entre uma "recampesinização" e os ideais de modernidade. O tom do trabalho é privilegiar o lado cultural na análise do campesinato. Por isso, a autora contrapõe-se a leituras que seriam mais voltadas para a esfera econômica. Enquanto Fernandes privilegiaria o aspecto político-econômico ao definir territorialização, Marques segue a linha que incorpora a dimensão cultural à definição de território camponês, no sentido de atentar mais para o significado da terra para o grupo estudado do que para os aspectos de produção material (MARQUES, 2000: 2932).

O trabalho de Marques traz uma discussão sobre a origem social e cultural dos sem terra e mostra a abrangência desta categoria, que engloba uma multiplicidade de grupos sociais. Nessa discussão, a autora coloca que pode haver um maior ou menor grau de "campesinidade", , decorrente da vida de cada um (MARQUES, 2000: 25). O predomínio das relações de parentesco entre os assentados mostra um elevado grau de “campesinidade". São as relações de parentesco e não as de produção que são determinantes.

Fernandes e Marques concordam que há algo que determina um território camponês, só discordariam sobre qual é o determinante, o político-econômico ou o cultural. A conquista da terra, tanto para esses dois autores quanto para os demais a serem vistos, significa a realização de um projeto de vida camponês em meio à sociedade moderna. Os assentados criam uma comunidade camponesa.

A questão de como e porque os trabalhadores que passaram pela expropriação ("des-territorialização") continuam a desejar o retorno ao estilo de vida camponês ("reterritorialização") é o ponto central da tese de Simonetti (1999). A autora, que realiza um estudo sobre uma das comunidades de assentados na fazenda Reunidas, em Promissão/SP, também enfoca a territorialização do MST, no sentido de que ao se conquistar um assentamento abrem-se as perspectivas de se conseguir outro; portanto, se a luta acaba com a conquista de uma única fração de território, não ocorre a territorialização (SIMONETTI, 1999: 70).

Mitidiero (2002: 40) faz uma revisão da produção de geografia agrária recente para reforçar a especificidade da disciplina: o território e o conceito de territorialização. $\mathrm{O}$ autor

\footnotetext{
${ }^{5}$ A noção de campesinidade é originalmente trabalhada por Woortmann (1990).
} 
trabalha com a formação e territorialização do MLST (Movimento de Libertação dos Sem Terra) e chama a atenção para o fato de se escrever sobre um novo território camponês, mas não se explicar o que é, quais são seus termos e sua relação com o Estado e, principalmente, que a concepção de território conquistado é insuficiente, analiticamente falando. Enfim, o conceito de territorialização deveria ser visto apenas como um processo de luta pela terra e não como domínio completo de frações do território (MITIDIERO, 2002: 62).

Para Almeida (2003), que estuda a luta pela terra por distintos grupos sociais no Mato Grosso do Sul, o "assentamento é uma unidade territorial, parcela do território capitalista sob domínio camponês e, quando existente, é inequívoca sua distinção em relação à grande propriedade, ao uso que o capitalista faz de sua parte do território" (ALMEIDA, 2003: 272). A autora critica a concepção de territorialização de Fernandes (1996) porque a territorialização não é "propriedade” do Movimento, mas um processo decorrente da luta camponesa na sociedade capitalista.

Fabrini (2003) coloca o seguinte: "os assentamentos se constituem no espaço de realização de ações coletivas e comunitárias em que os camponeses constróem o território" (FABRINI, 2003: 10). Ele mostra que a forma como os lotes estão distribuídos nos assentamentos estudados leva ao isolamento das famílias; então, as relações de parentesco, vizinhança e de afinidades políticas promovem a superação do isolamento. O autor chama a atenção para o papel das redes no interior do assentamento. "Se, por um lado, o capital constrói uma rede de relações territorializadas no espaço para viabilizar sua reprodução, os trabalhadores também as constróem, no sentido de negar a reprodução da sociedade dividida em classes, como fazem os assentados e o MST” (FABRINI, 2003: 230). O autor analisa os assentamentos da região centro-oeste do Paraná ligados à Cooperativa de Trabalhadores Rurais e Reforma Agrária do Centro-Oeste do Paraná Ltda (Coagri) como forma de resistência política.

Também escrevendo no registro teórico de que a desapropriação representa a conquista de frações de território dominadas pelo capital, Gonçalves (2004) coloca que é na luta na terra e não na luta pela terra que se confirma a territorialização do MST. Neste sentido, pode ocorrer a "desterritorialização" do MST no assentamento por não conseguir fortalecer a socialização política; assim, quando se perde o vínculo, o assentamento não é mais um território do MST, como teria ocorrido na região do Pontal do Paranapanema/SP, conclui o autor (GONÇALVES, 2004: 312-14). 
De modo geral, o ponto comum entre eles é que a territorialização do campesinato ocorre sobre o território do capital, logo, implica necessariamente a "desterritorialização" deste. Além disso, o território camponês seria um local de produção e de valores éticos distintos do modo de produção capitalista. Porém, a discussão mais aprofundada passa por quais são as garantias de que haja a consolidação da fração do território camponês: a apropriação do território, ou o resgate da cultura e da moral camponesa, ou as formas de produzir e de constituir relações não-capitalistas no novo território.

De todos esses autores, Fabrini (2003) é o único a trazer para a análise a importância das redes. O texto de Mitidiero (2002) abriu espaço para se indagar sobre o que há nesse território camponês. Essa abertura possibilita a saída da dicotomia território camponês versus território do capital ${ }^{6}$. Sabe-se que há conflitos internos nos assentamentos decorrentes tanto da heterogeneidade dos moradores quanto da divergência entre os projetos: o de reconstrução da campesinidade, o comunitário cristão, o de produção coletiva do MST e o de produção para o mercado. $\mathrm{O}$ fato de haver um território camponês não implica diretamente o desaparecimento ou a não reprodução de relações de produção capitalista. O que há no território camponês? Há conflitos sociais e eles produzem o espaço interno do assentamento.

\section{Conflitos internos e heterogeneidade dos assentados}

De um modo geral, todos os trabalhos expostos nessa parte têm pontos comuns, preservando-se a devida especificidade de cada uma das análises. Eles expõem os conflitos internos entre os assentados. Esses conflitos são decorrentes do desencontro entre as orientações da organização do MST sobre a necessidade de produção coletiva e as práticas de trabalho familiar dos assentados. Logicamente que os conflitos não se restringem à dinâmica interna dos assentamentos e à relação com as lideranças do Movimento, eles também ocorrem na discussão com os governos, quanto aos financiamentos, à demarcação de lotes, à assessoria técnica etc. Os trabalhos partem de pesquisas empíricas em assentamentos (e/ou ocupações) e, então, fazem a contraposição ao posicionamento das lideranças do Movimento, que muitas vezes querem sobrepor seu projeto político aos assentados. É a empiria que reforça a autoridade da argumentação crítica a certas "falhas" da direção do Movimento. Os textos também referem-se em comum ao "novo": novo campesinato, novos assentamentos. Alguns trabalhos são mais claros do que outros em

\footnotetext{
${ }^{6}$ Não pretendo sugerir que os trabalhos citados caem na pura dicotomia território camponês x território do capital, seria uma simplificação dos mesmos. Utilizei tal dicotomia apenas como recurso descritivo.
} 
mostrar o que de fato é novo ${ }^{7}$. Não resta dúvida de que as ocupações de terras e, conseqüentemente, a formação de assentamento de reforma agrária promovido por um movimento social camponês de âmbito nacional é uma novidade nos últimos vinte anos da história do país. Porém, o que se pode concluir das leituras é que a novidade são assentamentos de reforma agrária com uma população de origem e trajetórias muito variadas, que inclui a vida na cidade ${ }^{8}$. Logo, há conflitos de interesses, que são retratados no desencontro entre o modo de produção familiar e os modelos de produção em coletivos. Enfim, os estudos mostram que os conflitos internos nos assentamentos são recorrentes, principalmente quando se trata das formas de organização da produção agropecuária em coletivos ou "individual”. Cabe agora esmiuçar as características desses conflitos.

Há trabalhos que tratam diretamente do conflito interno como tema, como dos sociólogos D’Incao e Roy (1995), da antropóloga Miranda (1998 e 2003), do historiador Schreiner (2002) e do geógrafo Mitidiero (2002). Certamente é um novo olhar sobre os camponeses, que se fez mais presente na última década. Outros textos não se concentram no tema do conflito, mas acabam por abordá-lo, como dos geógrafos Marcos (1996), Fernandes (1996 e 1999), Simonetti (1999) e Marques (2000) e do sociólogo Carvalho (1998), do historiador Duarte (1998), da psicóloga Narita (2000), do sociólogo Pereira (2000) e do urbanista Lopes (2002). Provavelmente o fato de haver nos assentamentos de reforma agrária uma heterogeneidade de pessoas, em termos de origem regional, de trajetórias e de experiências de vida, conforme constatado por uma parcela desses textos, determine certo grau de conflitos sociais internos. As comunidades mais homogêneas também enfrentam conflitos, como demonstrou Marcos (1996); porém, nesses grupos deve haver maior tolerância do que nos assentamentos, onde se reúnem pessoas com poucos laços anteriores. No caso de grupos mais homogêneos, a tolerância manifesta-se no menor recurso ao Judiciário, do que no caso de grupos mais heterogêneos. Portanto, há um novo olhar e também um novo perfil populacional nos campos brasileiros.

Com um dos primeiros livros a tratar de conflitos internos em assentamentos de reforma agrária, D’Incao e Roy (1995) contribuem com a análise da prática entre os assentados das "invalidações recíprocas". Ocorre no assentamento um círculo vicioso de

\footnotetext{
${ }^{7}$ Fernandes (1999: 283) mostra uma diferenciação entre o "sem terra" e o conhecido "posseiro". Segundo ele, o posseiro é aquele que se encontra nas frentes de expansão e o sem terra é o que ocupa as terras pertencentes ao capital. Portanto, "sem terra" é o "novo"em relação ao posseiro.

${ }^{8}$ Sobre o perfil dos sem terra, Fernandes (1999: 276) chama a atenção para o fato de que a maior parte dos membros do MST nunca teve terra própria e uma parte deles nunca trabalhou no campo. No estudo de Simonetti (1999), a maioria dos assentados era proveniente das cidades. Marques (2000) mostra que "sem terra" é uma nova categoria social.
} 
um criticar o outro e vice-versa, a ponto de invalidar as ações que visam modificar a vida coletiva. Os autores atribuem essas "invalidações recíprocas" ao fato de os assentados terem sido socializados por meio de relações perversas de dominação e, por isso, só saberiam reproduzi-las ao invés de construírem relações democráticas. No entanto, acreditam os autores que é possível e necessário o aprendizado de relações democráticas, o que propiciaria tornar aquela população sujeito de sua própria história. Por isso, os pesquisadores atribuem-se o papel de fazer um trabalho intervencionista de mediação nas relações coletivas do grupo. Eles constatam que só pela ação externa o grupo de moradores pode perceber e rever sua posição de reproduzir relações dominadoras. O "diálogo crítico" é usado na pesquisa como instrumento para mostrar aos entrevistados que eles estão sendo dominadores e que poderiam ser mais igualitários. Haveria no assentamento uma paralisia devido à falta de uma mediação competente (D’INCAO e ROY, 1995: 164). Ao colocarem-se como mediadores ${ }^{9}$, os pesquisadores procuram não julgar os comportamentos e as posições dos moradores e sim fazê-los refletir sobre os seus princípios morais.

O trabalho apresenta três concepções de sociedade presentes nas lutas nos assentamentos. A visão das Comunidades Eclesiais de Base (CEBs) propõe o ideal de vida comunitária, baseado na igualdade, na fraternidade e na solidariedade. A posição da coordenação do MST, e/ou de militantes políticos de esquerda, está voltada para um modelo de socialismo. Por fim, os técnicos estatais defendem as associações de produção direcionada para o mercado. Portanto, o texto mostra que no assentamento há mais posições do que a simples polarização entre os "individualistas" e os "coletivistas".

D'Incao e Roy baseiam-se em dois pressupostos sobre os assentados: eles são socializados por meio de relações dominadoras e as lideranças ligadas ao MST possuem visões autoritárias. Ao se fixarem nesses pressupostos, os autores deixam para segundo plano a percepção da multiplicidade de posições que as pessoas podem apresentar (como eles mesmos reconhecem, conforme expresso na nota 12, p. 272). Quer dizer, os autores tendem a reduzir as diferentes representações sociais que as pessoas apresentam nas relações a uma única posição: dominador ou dominado. Pode ser que a socialização dos

\footnotetext{
${ }^{9}$ Observa-se que Fernandes se contrapõe à nação de mediação, segundo ele comumente usada por sociólogos e que daria um sentido de intervenção e/ou arbitragem, e opta pela noção de "articulação" em relação aos colaboradores da luta dos sem terra. Para o autor, a direção política do Movimento deve ser dos trabalhadores rurais, sem intervenções, porém, o Movimento também necessita do apoio, resultante de "articulações" (FERNANDES, 1999: 180, nota 44). Esse é um debate em aberto sobre visões plurais ou singulares de orientação da luta pela terra e sobre a possibilidade de diálogo democrático para ações conjuntas.
} 
camponeses seja autoritária, devido às relações hierárquicas na família e de subalternidade e de favores aos fazendeiros, em comparação ao mundo urbano liberal regido por contratos formais. Porém, a pergunta que se levanta em relação ao trabalho de D’Incao e Roy é: em que medida essa separação de mundos garante que só os assentados reproduzam relações de dominação e os pesquisadores não? Em outras palavras, o quanto está incorporado em nossas práticas urbanas a gestão democrática dos conflitos ou da produção? Além desta, pode-se dizer que um pressuposto dos autores é oposto ao aqui adotado: não resta dúvida que entre os assentados há relações de dominação, mas o fato de eles terem entrado para a luta pela terra representa, justamente, uma reação à dominação. (O pressuposto adotado aqui foi exposto na Introdução da tese: o lado anti-autoritário da luta pela terra.)

O trabalho de Miranda (1998), que consiste de uma etnografia do conflito interno no assentamento Fazendas Reunidas, em Promissão/SP, tem como foco os processos de reconstituição da condição (ou ethos) camponesa. O cerne do trabalho é a tensão entre o modo de vida camponês, baseado na liberdade e na autonomia da produção (como, quando e o quê produzir), e os projetos de organização coletiva e/ou cooperativa, visando uma maior racionalidade de produção (voltada para o mercado), postos pela direção do MST. Em outras palavras, há um conflito entre o "ethos camponês" e a "ética capitalista", da primazia da racionalidade econômica ${ }^{10}$. Entre os assentados, há diferentes grupos formados por pessoas que vieram do campo e outras que já viveram o processo de expropriação e trabalhavam nas cidades. O conflito manifesta-se entre aqueles que defendem o trabalho em cooperativas e aqueles que preferem trabalhar só com seus familiares. Em 1992, os assentados formaram a primeira cooperativa de produção agropecuária - a Cooperativa de Produção Agropecuária Padre Josimo Tavares (Copajota) -, em que só a produção era coletiva. Três anos depois, uma outra cooperativa foi criada e uma parte das atividades domésticas também foi coletivizada, com a criação de uma creche. Então a autora dá um exemplo de insatisfação com a coletivização da esfera doméstica: há um rompimento com essa cooperativa porque uma família prefere cuidar do filho e trabalhar em casa, ao invés de deixá-lo na creche para trabalhar no coletivo. Muitos dos assentados, então, optaram pela produção familiar em seus sítios e não numa área coletiva. O trabalho mostra que o cooperativismo do MST promove alterações no habitus camponês porque a decisão sobre a produção foge ao controle familiar e o chefe de família perde sua autoridade patriarcal.

\footnotetext{
${ }^{10}$ A autora chama de ética capitalista a racionalidade e a produção para o mercado. Sabe-se que produção racional para o mercado não é o que necessariamente define o modo de produção capitalista. Esta questão deve ser aprofundada mais a frente.
} 
Vamos ver, à frente, que o trabalho de Schreiner (2002) aprofunda as críticas ao modelo cooperativo do $\mathrm{MST}^{11}$.

Ser assentado, segundo Miranda, é a possibilidade de existir como camponês. No entanto, é preciso, para existir como tal, ter condições econômicas que só a posse da terra não garante.

A adaptação dos assentados à nova situação de pequenos sitiantes e o seu bom desempenho vai depender das suas experiências passadas e do seu nível de capitalização. A tendência geral no assentamento é tentarem estabelecer-se enquanto sitiante, com autonomia de produção e de organização do trabalho no interior do sítio (MIRANDA, 1998: 126-7) ${ }^{12}$.

Portanto, a autora chama a atenção para a cultura (e a capitalização) como determinante da adaptação. Neste sentido, podemos inferir que aqueles que não possuem o ethos camponês dificilmente adaptar-se-ão. Mas, se a autora fala em "(re)campenisação", está implícito um processo de (re)constituição de valores, que, no entanto, é minimizado por ela ao colocar determinantes ligados à trajetória pessoal para a adaptação ao modo de vida camponês.

Em 2003, Miranda aprofundou o estudo dos conflitos na fazenda Reunidas colocando o foco nas relações dos assentados com processos jurídicos sobre irregularidades. A questão que perpassa a tese é a condição de permanência dos moradores e de seus descendentes no assentamento. Por exemplo, mostra que há uma prática comum de repassar lotes para filhos de assentados, porém, isto pode ser irregular principalmente quando se caracteriza "venda"; mas, de 153 processos jurídicos realizados pelo INCRA, em 1998, somente em 7 confirmaram-se “irregularidades" e em 2 houve propósitos “especulativos". A autora chama a atenção para a necessidade de um apoio técnico mais intensivo para os beneficiários com pouca experiência em plantio e coloca que a inaptidão e as condições socioculturais podem empurrar alguns para fora do assentamento,

\footnotetext{
11 Os textos de J. S. Martins, da década de 1980, já apontavam para a distância entre os ideais políticoideológicos dos mediadores da luta pela terra (primeiro o Partido Comunista e depois a Igreja Católica) e o dos camponeses. Zander Navarro vai ser um dos primeiros autores a publicar críticas à direção do MST por sua postura não-democrática e pelo seu projeto cooperativista. Como veremos adiante, Fernandes (1999) e Schreiner (2002) retomam as críticas de Navarro ao modelo cooperativo do MST; Fernandes (1999: 172-4) acrescenta que o Movimento abandonou essa experiência porque não se consolidou. O próprio Stedile, uma das lideranças do MST mais conhecidas, reconhece o erro do projeto cooperativo quando coletiviza tudo, e não só a produção (Stedile \& Fernandes, 1999: 103).

${ }^{12}$ Interessante observar que Simonetti (1999), que estuda o mesmo assentamento que Miranda (1998), não aponta essa tendência para o isolamento nos sítios.
} 
retomando a questão do ethos campesino como determinante da permanência na terra (MIRANDA, 2003: 103-4) ${ }^{13}$.

O trabalho de Schreiner (2002) aprofunda as críticas ao modelo cooperativo do MST. O ponto central são as contradições nos processos de organização das diferentes formas de cooperação ou de associativismo, mais especificamente entre as formas de cooperação próprias da cultura camponesa e as induzidas pelos mediadores da luta pela terra.

Através do estudo empírico em três assentamentos de reforma agrária nas regiões sudoeste e oeste do estado do Paraná, entre 1985 e 2001, o autor critica a concepção dualista da direção do MST, que distingue "coletivismo versus individualismo", e propõe que as políticas de cooperação sejam repensadas. A seguir, são destacados alguns pontos relevantes dos estudos sobre os assentamentos em relação à organização da produção.

No assentamento Vitória, no município de Lindoeste, o autor encontrou uma briga pessoal, mas que revelava um conflito entre um grupo fortemente ligado ao MST e outro que questionava essas orientações e que se sentia perseguido e discriminado. Nos primeiros anos desse assentamento, alguns moradores optaram pelo cultivo comunitário. Havia dois grupos que ocupavam áreas distintas da fazenda e que se acusavam reciprocamente quando havia problemas internos ou negociações com o INCRA. Com o passar dos anos, as desavenças foram desaparecendo. Quando saiu a emissão de posse, as famílias ocuparam os lotes e, então, começou um processo de individualização. A opção por cultivar os lotes individualmente foi vista pela organização do MST como evidência de uma mentalidade "atrasada". As lideranças do Movimento, por sua vez, formaram dois grupos coletivos, em que se pretendia coletivizar a terra e o trabalho. Após três anos, os assentados começaram a abandonar o coletivo, mesmo reconhecendo as vantagens do mesmo, porque discordavam quanto à proporção entre a quantidade trabalhada e o valor recebido. Com o enfraquecimento dos coletivos, três famílias formaram um "semicoletivo", que consiste de atividades econômicas em conjunto, preservando a individualidade para o trabalho doméstico e para o roçado da família. Nesses "semicoletivos", o autor aponta que as famílias usaram de critérios como modo de ser e etnicidade para incluir ou excluir outras famílias do grupo (SCHREINER, 2002: 223-248). No assentamento Terra Livre, no município de Nova Laranjeiras, desde o início da ocupação, em 1990, uma área da fazenda foi destinada para a experiência de trabalho

\footnotetext{
${ }^{13}$ Vale observar que o relatório FAO/PNUD/MARA (1992: 19) aponta para uma média nacional de $22 \%$ de desistência ou abando do total de beneficiário do programa de reforma agrária.
} 
coletivo. De um total de 22 famílias e 4 solteiros, 12 famílias desistiram da cooperativa e 3 foram expulsas.

O autor vê as associações, os coletivos e "semi-coletivos" como tentativas de romper com o tradicional modo de produzir baseado no trabalho familiar. Assim, contrapõe as formas de sociabilidade e de solidariedade da cultura camponesa estudada com a análise das formas de cooperação propostas pelo MST. Para ele, não há porque se propor uma única forma de propriedade nem de organização do trabalho, como muitas vezes pretende o MST. Deve-se dar livre escolha aos assentados, que a seu modo preferem a organização familiar e também sentem necessidade de alguma cooperação, como a dos mutirões. Além disso, a troca ou venda de lotes pode ser vista como uma forma de se fugir das pressões exercidas pelas lideranças do MST para o trabalho coletivo (SCHREINER, 2002: 327-328). Vale observar que o trabalho de Carvalho (1998), que será visto mais a frente, constata que a maior diversidade de formas de associação ou de cooperação ocorre nos assentamentos em melhores condições sócio-econômicas.

Schreiner esmiúça as críticas ao modelo de cooperativismo proposto pelo MST. O ethos camponês, em que o lote familiar é como um microcosmo, defronta-se com a proposta dos laboratórios experimentais, elaborados por Clodomir de Morais para o MST. Nessa proposta, a produção camponesa livre e autônoma é vista como artesanal, individualista e "atrasada". Neste sentido, o MST passa a reproduzir preconceitos contra o camponês, colocando-o como atrasado e individualista, enquanto o assalariado do campo seria moderno e propenso à organização coletiva. Por fim, o laboratório experimental é algo que se impõe como uma coletivização a priori sem definir o porquê e como, e não parte da realidade concreta do assentamento, dos costumes dos assentados e das condições de produção encontradas (SCHREINER, 2002: 366-373) ${ }^{14}$.

Quando um modelo de produção é imposto, o autor mostra que a subordinação gera também práticas de insubordinação (SCHREINER, 2002: 376) ${ }^{15}$. Ele constata que a lógica da positividade da modernidade permeia a concepção político-ideológica do MST, no sentido de que o moderno, por ser novo, impõe-se ao passado individualista. Assim conclui que é preciso acabar com o discurso do camponês como resíduo do passado, para se

\footnotetext{
14 Almeida (2003) aprofunda as críticas à organização do MST ao mostrar que a chamada "revolução cultural" (reconhecimento e tolerância em relação às aspirações dos assentados) não representou uma mudança de essência em relação aos laboratórios experimentais, criticados na tese de Schreiner, entre outros.

${ }^{15}$ Sobre as formas de organização impostas, ver Carvalho (1998).
} 
encontrar modos de produção que respeitem e incorporem aspectos da cultura camponesa e que não sejam impostos ${ }^{16}$.

Pela tese de Schreiner, fica claro que a polaridade entre trabalho familiar (individual) versus coletivização não é estanque. Há ambigüidades e ambivalências entre os assentados, alguns querem o trabalho individual, outros querem o coletivo ou "semicoletivo". De modo que a produção coletiva não é só uma imposição externa aos assentados feita pelos líderes do MST, ela também é incorporada e re-trabalhada por aqueles. Alguns assentados começaram em coletivos e desistiram, outros partiram do “individual" para o coletivo. É o ponto trabalhado por Carvalho (1998).

Do texto de Mitidiero (2002), pode-se concluir que os rachas (ou dissidências que formam outros grupos) são formas de gerir conflitos internos dos movimentos de luta pela terra. A hipótese do autor é que novos movimentos de luta pela terra surgem em decorrência de rachas internos dos grupos originais. Segundo ele, há três formas de conflito que resultam em rachas: conflito explícito e permanente no cotidiano; conflito permanente, mas não explicitado até o racha; conflito concomitante ao racha (MITIDIERO, 2002: 89).

Dos textos que abordam indiretamente os conflitos internos, cronologicamente há a primeira contribuição da dissertação de Marcos (1996) sobre a Comunidade Sinsei, no município de Guaraçai/SP. A autora estuda experiências de produção comunitária camponesa em diferentes tempos e lugares e, empiricamente, as comunidades de descendentes de imigrantes japoneses: a Yuba e a Sinsei. Mostra que, nas comunidades estudadas, há conflitos entre gerações e relativos às retiradas dos ganhos com a produção: os mais velhos não aceitam as propostas inovadoras dos jovens, apesar dos direitos a voz e voto serem iguais, e também ocorrem reclamações sobre aqueles que trabalhariam menos ou que comprariam coisas mais caras. A autora interpreta esse segundo tipo de conflito pela contradição entre os estímulos da sociedade capitalista e o princípio "de cada um de acordo com suas possibilidades a cada um conforme suas necessidades".

O primeiro trabalho de Fernandes (1996) mostra que com a estratégia de massificação da luta, decidida no $5^{\circ}$. Encontro Nacional do MST de 1989, resultou numa

\footnotetext{
${ }^{16}$ Cabe destacar que com o trabalho de Schreiner - que segue a orientação teórica de H. Lefebvre, J. S. Martins e A. U. Oliveira (SCHREINER, 2002: 16, nota 16) - ocorre uma recuperação da crítica política dessa linha teórica, que teria atenuado seu potencial em trabalhos mais recentes de J. S. Martins. Para este autor, haveria uma intransigência do MST em aceitar dialogar com o governo federal de Fernando H. Cardoso. Schreiner mostra essa posição de J. S. Martins (em: Reforma Agrária: o impossível diálogo, de 2000) para se contrapor e dizer que há um antagonismo entre o modelo de desenvolvimento agrário proposto
} 
maior distinção entre trabalhadores rurais e militantes do Movimento. Nota-se que essa distinção também levou a conflitos entre acampados e lideranças sobre permanecer numa área ou partir para maiores conquistas, dentro da série de ocupações promovidas na região do Pontal do Paranapanema, oeste do estado de São Paulo, na segunda metade da década de 1990 (FERNANDES, 1996: 169-218).

Uma questão central pode ser colocada sobre a metodologia dos trabalhos de Fernandes. Os dois textos contextualizam e historicizam as lutas pela terra, a partir de um fim já sabido: a constituição de um movimento de camponeses (que passam a se denominar "trabalhadores rurais") sem terra de dimensão nacional e voltado para a ocupação de terras. Portanto, o autor faz uma leitura do nascimento do Movimento olhando os fragmentos do passado através de um presente unificado e pronto, porém o recorte espacial encobre o tom teleológico.

Simonetti (1999: 138) estuda o assentamento Fazendas Reunidas em Promissão/SP e o conflito interno de uma cooperativa. O problema específico é com a divisão do resultado da produção: como as retiradas são divididas por membros cooperados e não por famílias, as famílias mais numerosas retiram mais e as menores ficam sempre com pouco. Quem reclama é, ainda, acusado de ser "capitalista"; no entanto, a autora mostra que uma das pessoas que se sentia prejudicada pelo sistema de retiradas da cooperativa tem os ideais cristãos de terra coletiva e de negação da propriedade privada. Uma das saídas para tal controvérsia foi romper com a cooperativa e formar uma associação de moradores. Com isso, a autora conclui que há “(...) diferentes formas de campesinidade coexistindo nessa diversidade de situações" (SIMONETTI, 1999: 167).

O trabalho de Marques (2000) também menciona os conflitos internos. Segundo ela, na comunidade camponesa, os laços de companheiros de luta são recriados, mas também são reforçadas as divisões internas. A associação de moradores serviu também para acirrar as disputas internas, principalmente entre os coletivos e os "individualistas". $\mathrm{Na}$ associação, os líderes concentram poder, em oposição ao que acontecia na época de acampamento quando tudo era decidido em assembléia (MARQUES, 2000: 151). Ela enfoca o conflito entre uma "recampesinização" e os ideais de modernidade.

De um lado, o INCRA visa a inserção das famílias assentadas no sistema econômico em vigor a partir de uma intervenção concebida segundo parâmetros da racionalidade técnica e os valores da ideologia moderna. De outro, os sem-terra visam tornar-se donos de sua

por aquele governo federal e o do MST, por isso, é que não pode ocorrer diálogo entre os dois (destaque meu). 
própria terra para realizar um projeto de vida pautado pela ética camponesa (MARQUES, 2000: 96-7).

É a mesma visão presente no trabalho de Miranda e, conseqüentemente, valem as mesmas observações: há uma essência camponesa expressa numa ética, num modo de vida, num grau de "campesinidade". Então, se há uma essência determinante para que as famílias fiquem na terra, só pode ser "novo camponês" aquele que já fora camponês.

A conquista da terra, diz a autora, significa para o grupo estudado a realização de um projeto de vida camponês em meio à sociedade moderna. Os assentados criam uma comunidade camponesa. "Na medida em que a vida vai ganhando normalidade, tradições culturais são revividas, formas tradicionais de solidariedade são recriadas e os 'posseiros' vão assumindo um modo de vida camponês" (MARQUES, 2000: 122). Na comunidade camponesa, os laços de companheiros de luta são recriados, mas também se reforçam as divisões internas, enfatiza a autora. Assim, o tema é tratado como recriação camponesa, no sentido de negação da proletarização, mesmo que os personagens tenham passagens pela cidade.

Passando para outro autor, Duarte (1998) faz um balanço histórico dos movimentos no campo em Goiás nos últimos vinte anos e, principalmente, se debruça sobre a trajetória de três assentamentos, nos municípios de Cristalina e Goiás.

O autor atribui ao desemprego da década de 1990 o aumento significativo de pessoas que retornaram para o meio rural (DUARTE, 1998: 90-5). Assim, explicita que seu enfoque está na base material que leva à ocupação. Porém, não deixa de atentar também para alguns aspectos simbólicos.

Dentre muitos pontos em comum com o geral retratado nos trabalhos sobre assentamentos de reforma agrária, vale destacar uma situação nova contida nesse texto. Num dos assentamentos estudados, um dos moradores inventou uma tradição: a garrafa do galho florido. Quando ocorre um mutirão, os presentes tomam um gole de pinga de uma garrafa com um galho com uma flor em seu gargalo, que circula entre eles. Beber a pinga é assumir o compromisso de união e a garrafa é um símbolo desta união, interpreta o autor. Depois, a garrafa é passada para o próximo a ser beneficiado pelo mutirão (DUARTE, 1998: 106-8). Este caso é destacado porque exemplifica que os elos de união entre os assentados podem ser criados e aprendidos na convivência.

Por fim, o autor procura conciliar os desencontros entre as propostas da direção do MST e os interesses dos camponeses. Num primeiro momento, mostra que o MST aparece naquela região de Goiás como um sujeito externo, que se impõe sem reconhecer a 
importância da religiosidade naquela cultura (DUARTE, 1998: 312). Mas, na conclusão, o autor mostra a necessidade de se encontrar um ponto em comum entre o lado do camponês que rejeita a coletivização (proposta pelo MST), porque quer ter autonomia para produzir, e o lado da necessidade de cooperação na produção, para que a pequena propriedade agrícola seja viável.

Por meio de um extenso trabalho empírico, Carvalho (1999) estuda a interação e as possibilidades de coesão e de identidade social entre vários assentamentos pelo Brasil. A contribuição desse trabalho para a questão dos conflitos sociais internos é observar que os assentados formam juízos de valor sobre os demais, baseados na inserção social das pessoas anterior ao assentamento e consideram que isto reflete, positiva ou negativamente, no associativismo.

A dissertação de Narita (2000) não se volta diretamente para os conflitos internos nos assentamentos. Ela estuda o lado psicossocial que levou as pessoas a ingressar no MST para participar de ocupações em Presidente Bernardes, região do Pontal do Paranapanema, oeste do estado de São Paulo. A autora também mostra o desencontro entre as propostas de coletivização feitas pela direção do MST e aqueles que querem trabalhar "individualmente" (NARITA, 2000: 134). No entanto, aponta também que os assentados acreditam que os "individualistas" podem ser convencidos que a produção coletiva apresenta maior viabilidade econômica (NARITA, 2000: 138).

Pereira (2000), em análises sobre assentamentos de Goiás e do Paraná, mostra que há duas orientações em relação a valores, mediadas pela CPT e pelo MST, respectivamente: a tradicional baseada na família e a coletivista. No caso dos valores tradicionais baseados na família, presentes no assentamento de Goiás, a forma de sociabilidade não aceita a exploração coletiva da terra porque impediria o princípio de reciprocidade entre os moradores. Então, o "isolamento" pode ser visto como uma forma de evitar conflito.

Quanto ao registro das divergências entre os assentados, vale destacar que o trabalho de Lopes (2002), ao estudar a formação de um pólo urbano num assentamento, mostra que as posições - sejam elas das lideranças, dos assentados, dos técnicos ou dos assistentes - não são fixas, elas são retrabalhadas com as discussões internas. Num estudo específico sobre a formação de uma cidade na fazenda Giacometi/PR, mostra que os assentados também querem sair do isolamento de seus lotes para ter uma "centralidade", que havia durante a fase de acampamento e se perdeu. A "centralidade" buscada é a da cidade, mas de uma nova cidade que precisa ser elaborada em conjunto entre técnicos e 
assentados. O autor analisa sua experiência como consultor do Movimento para projetar uma cidade no assentamento Ireno Alves dos Santos e apresenta uma verdadeira polifonia em relação ao projeto. Mostra o quanto é complicado criar uma cidade num mundo rural e que o Movimento, em alguns momentos, acaba por reproduzir a sociabilidade capitalista ao conceber a cidade como local da produção. No entanto, quando o Movimento "se prescreve como sujeito coletivo a partir do indivíduo que produz vida e não exclusivamente mercadoria, parece-nos (...) que alcança maiores avanços em termos de emancipação social (...)” (LOPES, 2002: 325). O assentamento Ireno Alves dos Santos também é estudado por Fabrini (2003), pelo aspecto da organização política advinda do cooperativismo.

Por fim, de um modo geral, todos os trabalhos expostos nessa parte têm pontos em comum, preservando-se a devida especificidade de cada uma das análises. Eles expõem os conflitos internos entre os assentados e/ou conflitos entre assentados e as lideranças locais do MST (e MLST), mesmo que não os tratem como tema central. Esses conflitos são decorrentes, em sua maioria, do desencontro entre as orientações da organização do MST sobre a necessidade de produção coletiva e as práticas de trabalho familiar dos assentados. Logicamente que os conflitos não se restringem à dinâmica interna dos assentamentos e à relação com as lideranças do Movimento, eles também ocorrem na relação com os governos, quanto aos financiamentos, à demarcação de lotes, à assessoria técnica etc. Os estudos mostram que os conflitos internos nos assentamentos são recorrentes, principalmente quando se trata das formas de organização da produção agropecuária em coletivos ou "individual". Conclui-se que, para os assentados, ficar no núcleo familiar e negar os projetos coletivos impostos é uma forma de gestão do conflito causado por tal exterioridade das idéias das lideranças. Então, a opção por sair do "coletivo" e ficar “individual” (produzir somente em família) é uma forma de gerir esse conflito. A opção por sair ou não entrar num coletivo é interpretada aqui como forma de evitar conflito, dentro de uma perspectiva de que há várias formas de gestão de conflito e uma delas é o evitar $^{17}$. Portanto, a gestão dos conflitos é aprendida na prática. Independentemente do "grau de campesinidade", os assentamentos apresentam-se como lugares de aprendizado da gestão (democrática) da vida pública (e da produção). Trabalhar em família é do ethos campesino; porém, isto não implica que não haja outras formas de solidariedade (mutirão, semi-coletivos) além das propostas de cooperativas do MST, em suas diferentes fases.

\footnotetext{
${ }^{17}$ Trabalha-se com a concepção de "avoidance", comum na literatura antropológica e sociológica sobre conflitos sociais e controle social; ver Black (1998: 74-94).
} 
É preciso destacar que há também um "projeto coletivista" de orientação cristã popular, independente daquele que seria imposto pela direção do MST. Além disso, as posições entre "individual” e "coletivo" não são as únicas e nem são cristalizadas, como constataram D’Incao e Roy (1995), Lopes (2002) e Schreiner (2002). Vale colocar que, enquanto alguns autores optam por uma abordagem "culturalista" em que o ethos camponês é contrário ao coletivismo, pode-se dizer que há campesinidade na cooperação, na solidariedade e na reciprocidade. Relembrando, historicamente na França houve dois regimes agrários, um com características "comunitárias" e outro baseado no “individualismo” (Cf. LEFEBVRE, 1986 [1953]: 169).

\section{Ethos camponês}

O ethos camponês é uma questão trabalhada, com diferentes designações, por alguns autores (MIRANDA, 1998; MARQUES, 2000, PEREIRA, 2000, SCHREINER, 2002) com base na noção de grau de campesinidade de Woortmann (1990). Esses autores utilizam tal noção para se contraporem ao projeto coletivista colocado pelo MST aos assentados, mostrando que a unidade familiar camponesa resiste a um modelo que tenta romper com esta unidade. O ethos camponês estaria baseado em princípios morais e não no econômico moderno, portanto, a lógica capitalista vai de encontro a essa moral. Outros trabalhos sobre campesinato brasileiro tratam desse enfoque, por exemplo, Barone (1996), que analisa o código moral dos trabalhadores rurais de Ribeirão Preto/SP durante as greves dos anos 1980.

Retomando a fonte, Woortmann (1990) constrói uma fenomenologia da "campesinidade", tomada como uma ordem moral e não como ordem econômica, baseando-se na etnografia brasileira sobre campesinato. Ele não pretende comprovar que sitiante, colono e agregado são camponeses, mas mostrar através de seus valores o que é a “campesinidade". Por isso, a coloca como uma qualidade presente em maior ou menor grau dependendo do grupo estudado. Resumidamente, a campesinidade consiste em excluir do círculo familiar as relações de caráter mercantil.

O ponto crítico que se apresenta é que os autores - como Miranda (1998 e 2003), Marques (2000) e Schreiner (2002), por exemplo - defendem a visão de que há um ethos camponês, como conjunto de características intrínsecas ao assentado. Logo, há uma situação paradoxal: se o camponês traz consigo seu ethos, reforça-se uma visão comum aos meios de comunicação, por exemplo, de que só é possível ser "novo camponês" quem já 
era camponês ${ }^{18}$. Mais do que isto, a noção de ethos é tida como um determinante da permanência no assentamento, então, comprova-se que quem ficou é camponês e quem teve de abandonar o lote não é (nem o fora). A noção tem a força de respeitar a classe camponesa e de poder criticar a postura oficial da direção MST; porém, perde força ao estabelecer distinções no universo entre os "mais" e os "menos" camponeses.

Pereira (2000), por exemplo, vai além desse registro ao analisar como duas orientações de valores distintas (mediadas pela CPT e pelo MST): a tradicional baseado na família e a coletivista. $\mathrm{O}$ autor trabalha o ethos sem colocar uma graduação.

Cabe dizer que há importantes contribuições dos trabalhos que mostram que o ethos campesino não é levado em consideração quando formas de organização coletiva são colocadas de maneira exterior aos assentados. Entre elas, mostrar que a direção do MST subestimou a força do caráter camponês e a possibilidade de fracasso ao contrariá-lo. Outra, aproximar-se do universo camponês por sua cultura e não por meio daquilo que as organizações de luta pela terra gostariam que fosse. Porém, foi encontrada na pesquisa aqui exposta uma disputa pelo ethos, ou melhor, por quem decide quem o tem.

Outra questão a ser destacada e que, de certo modo, se contrapõe a de cima é que o ethos camponês também é moldado pela organização do MST. Rapchan (1993) coloca que:

A participação no MST altera, sem dúvida, as categorias cognitivas e classificatórias com relação ao mundo. O sentido dado hoje a termos como organização, ocupação, acampamento, negociação e assentamento por parte dos assentados, tanto de Sumaré I quanto de Sumaré II, são resultado do contato com o próprio MST (RAPCHAN, 1993: 188).

Cooperativas, gestão, organização e sociabilidade

O cooperativismo tem uma centralidade no MST e as cooperativas de produção agropecuária são colocadas como uma forma "superior" de organização da produção (Cf. MST, 1993; MST e CONCRAB, 1994: 21). Logo, o Movimento privilegia o aspecto econômico do cooperativismo. Os textos que tratam de cooperativas, gestão ou organização nos assentamentos são: Carvalho (1998), Sizanoski (1998), Souza (1999), Singer (2002a), Christoffoli (2000), Fabrini (2003) e Feliciano (2003) ${ }^{19}$. Destacam-se, a

\footnotetext{
${ }^{18}$ Sobre a posição política, explorada pela mídia, de que há "falsos" camponeses entre os sem terra, ver Graziano (2003).

${ }^{19} \mathrm{Na}$ linha da organização, há também o trabalho de Matheus (2003), que expõe os assentamentos que seguem a proposta de "Comuna da Terra": assentamentos próximos aos grandes centros urbanos, com lotes
} 
seguir, as contribuições desses autores, sendo que o trabalho de Singer (2002a) será visto no tópico da sistematização.

Carvalho (1998) mostra que as induções de fora para dentro de formas de associativismo ou são desprezadas ou são reelaboradas pelos grupos sociais. Neste sentido, há dois processos na relação de tutela do Estado (via dispositivos legais) sobre os assentados, um em que as organizações são "consensuadas" (os envolvidos são sujeitos do processo) e outro em que as organizações são "constrangidas" (os envolvidos encontram-se em posição de subalternidade ou sem possibilidades de negar a indução para se associar). A associação, para o autor, é compreendida como uma mediação entre os interesses dos assentados e o seu ambiente social, neste sentido existem diferentes formas de associativismo que são trabalhadas pelo autor. Portanto, a associação é necessária na vida pública do assentamento. Duas hipóteses levantadas pelo autor colocam o paradoxo central para o MST e para a compreensão do estágio atual da questão agrária no Brasil: nos assentamentos predomina o comportamento "individualista" das famílias de trabalhadores rurais e as possibilidades de melhoria crescente e sustentável das condições estão relacionadas diretamente com a capacidade de estabelecer relações de cooperação. Ou seja, trata-se da questão de como conciliar a produção baseada nos interesses do núcleo familiar com a ampliação desta fronteira.

O estudo de Souza (1999) - que serve como fonte empírica para a teoria de Singer (2002a), vista a seguir - trata diretamente das formas de organização da produção nos assentamentos ligados ao MST no estado do Paraná. A hipótese comprovada pela autora é de que um dos fatores predominantes na organização de qualquer forma coletiva de produção é a práxis do assentado, composta pela experiência anterior, pela influência dos mediadores e pelo ideal de vida na terra (SOUZA, 1999: 4). Seria isso que determina a permanência do assentado na terra. Assim, o trabalho da autora avança nesta discussão ao colocar essa nação de "práxis" como determinante da permanência, ao invés do ethos visto acima.

Os trabalhos de Sizanoski (1998) e Christoffoli (2000) tratam das cooperativas nos assentamentos pelo prisma das contradições entre uma organização auto-gerida e o entorno capitalista. Chamam a atenção para a auto-gestão como contraponto ao modo de produção capitalista. Christoffoli (2000) estuda quatro cooperativas em assentamentos na região Sul do país. Conceitualmente, assume que cooperativa é "autogestão" das unidades produtivas,

de 2 a 5 ha para cada família morar e ter a horta individual e o restante da área para trabalho coletivo. Em algumas dessas experiência estão ex-moradores de rua. 
que é definida como a participação autônoma e o controle direto pelos trabalhadores sobre os processos de investimento, acumulação, eleição, admissão, de definição das formas de punição e recompensa e de tomada de decisões sobre planejamento, execução e distribuição de renda. $\mathrm{O}$ autor trata as formas de gestão como uma questão da democracia interna da cooperativa. Conclui que alguns dos coletivos estudados adotam uma concepção "basista" de democracia, com ampla participação dos associados, e com restrição ao grau de autonomia dado aos dirigentes e outros procuram reduzir os espaços de reuniões ou assembléias em troca de um aumento das atribuições e autonomia dos dirigentes para acelerar as tomadas de decisões no coletivo. Neste segundo caso, o nível de desenvolvimento sócio-econômico e os sistemas técnicos adotados são melhores do que no primeiro. Não há vinculação entre tamanho e idade do coletivo e a forma de democracia adotada. Em relação à hierarquia das organizações, há aspectos paradoxais. Por um lado, as pessoas buscam a construção de relações democráticas, por outro, um percentual significativo de associados defende coordenações com enfoque no rigor e na disciplina e na necessidade de líderes que apontem o rumo (CHRISTOFFOLI, 2000: 286-91).

Fabrini (2003) trata da organização de assentamentos na região centro-oeste do Paraná, que estão inseridos na Cooperativa de Trabalhadores Rurais e Reforma Agrária do Centro-Oeste do Paraná Limitada (Coagri). A principal contribuição é passar para a esfera política, e não estritamente econômica como enfatiza a direção do MST, a discussão sobre as cooperativas, no sentido de mostrar os ganhos na formação política dos assentados.

Feliciano (2003), num estudo sobre as dissidências do MST no estado de São Paulo, comprova que a organização interna dos acampamentos independentes não difere daquela realizada por movimentos sociais estabelecidos: há assembléias e setores de transporte, saúde, educação etc. "Essas formas são acúmulos de conhecimentos e de lutas construídos coletivamente que se espacializaram e se tornaram comum a todos os acampamentos e ocupações de terras" (FELICIANO, 2003: 211).

Gonçalves (2004), que realizou um estudo sobre os assentamentos do MST no município de Querência do Norte/PR, mostra que os assentamentos novos (entre dois e três anos) apresentam níveis de renda familiar entre menos de um e dois salários mínimos por mês. Nos assentamentos que superam essa faixa de renda é comum o trabalho fora do lote (como bóia-fria, geralmente) como principal fonte de recursos. Segundo o autor, o não acesso aos créditos agropecuários do governo é um dos principais fatores da baixa renda e da necessidade de trabalho fora do lote. No entanto, as famílias que estão assentadas em várzeas propícias ao cultivo de arroz conseguem rendas superiores a cinco salários 
mínimos por mês (GONÇALVES, 2004: 280-4). Foi registrado também o relativo sucesso na comercialização de leite e de arroz por uma das cooperativas.

\section{Os ritmos dos assentados: união, desunião e reunião}

Em quase todos os trabalhos expostos encontram-se elementos do ritmo de união, separação e reunião entre os assentados. São ritmos comuns na dinâmica dos assentamentos e reverberam conflitos em relação a projetos de cooperativas que são heterônomos, reconstrução da cultura camponesa voltada para a unidade familiar, formas de cooperação informal como a ajuda mútua, produção individual e participação em associação, famílias que dão certo em cooperativas e outras que desistem deste modelo. Exemplificando, há o texto de Rapchan (1993), ao retratar o assentamento Sumaré I/SP, o de Sizanoski (1998) sobre a Cooproserp (Cooperativa de Produção e Serviços de Pitanga) em Boaventura de São Roque/PR, o de Miranda (1998) e o de Simonetti (1999) sobre o assentamento Fazenda Reunidas, em Promissão/SP, a luta pela terra em Goiás Velho/GO nas fazendas Retiro e Retiro Velho analisadas por Marques (2000) e por Pereira (2000) e o de Gonçalves (2004) sobre as lutas em Querência do Norte/PR. É interessante completar essas observações com o trabalho de Bombardi (2001), que analisa uma experiência de reforma agrária de quase quarenta anos e mostra que, após conflitos e desistências, o assentamento consolida-se como um bairro rural e os lotes como sítios.

Apesar de terem sido destacados alguns casos, nota-se que a dinâmica de formar grupos, seja cooperativas ou associações, e de abandoná-los para seguir o trabalho familiar ("individual") ou para formar outro tipo de coletivo ou semi-coletivo faz parte da vida em

qualquer assentamento. É freqüentemente registrado que num período entre dois e cinco anos iniciais um assentamento sofre alterações como surgir um grupo, formar uma associação ou uma cooperativa ou famílias deixarem um empreendimento deste tipo e voltarem para o trabalho no lote ou formarem uma associação. Assim, o ritmo dessas dinâmicas muda somente após um período superior a esses cinco anos de formação de um assentamento. Logicamente, não se trata exclusivamente de tempo, mas também da configuração espacial do assentamento, que muda conforme a produção ser coletiva ou "individual" e conforme alteram as alianças entre os assentados. Essas mudanças na configuração espacial moldam a fração de território. 
Generalizações sobre a luta do MST: dos conflitos internos para os conflitos com o capital - a emancipação camponesa

Há poucos trabalhos que realizam sistematizações sobre o conjunto de ações do MST. Foram destacados três autores que se debruçaram sobre a questão. Carvalho (1998), através de um estudo sobre uma amostra de assentamentos de todo o país, chega às seguintes generalizações: nas regiões Nordeste, Centro-Oeste e Norte, onde estão 88,7\% do total de beneficiados da política de reforma agrária, encontram-se um baixo rendimento das famílias, precária relação com o mercado, dependência de recursos governamentais e baixa diversidade de associativismo; nas regiões Sul e Sudeste, onde vivem 11,3\% dos beneficiados, há melhores condições relativas de vida e de trabalho, relação intensa com o mercado, elevada diversidade de associativismo econômico, menor dependência dos recursos governamentais e maior potencial de captação de recursos junto a outras agências financeiras. Outra importante contribuição das análises de Carvalho é a constatação de que as formas de organização social dos acampamentos não perduram no assentamento (CARVALHO, 1999).

Dada essa realidade, uma das grandes questões de fundo colocada para o problema agrário brasileiro é o caminho para a construção da sociedade socialista e o papel do campesinato nesta trajetória. É uma discussão longa para ser esgotada aqui agora, mas é possível fazer apontamentos.

O MST tem claramente por objetivo construir uma sociedade sem exploradores, onde o trabalho prevalece sobre o capital, e difundir os valores humanistas e socialistas nas relações sociais (Cf. FERNANDES, 1996: 81). No entanto, coloca em seu programa de reforma agrária, entre outros objetivos, a geração de empregos e a formação de indústrias e de agroindústrias no interior do país, pontos que, em si, são compatíveis com o modo de produção capitalista. Mais ainda, o trabalho de Lopes (2002: 317), visto acima, chama a atenção para como o MST reproduz as concepções de sociabilidade capitalista ao pensar a cidade como local de produção e não como local de sociabilidade.

A crítica recorrente, em trabalhos como os de Schreiner (2002), Miranda (1998 e 2003) e Marques (2000), é que o projeto socialista de formação de coletivos cooperados, proposto pelas lideranças do Movimento, muitas vezes não se coaduna com a cultura camponesa baseada na produção familiar. Sabe-se que, por definição, o modo de produção familiar é não-capitalista, o que não quer dizer que seja necessariamente socialista. Aliás, de qual socialismo estamos falando? É uma pergunta em aberto, porque é algo a ser 
construído e não um pacote fechado. Os trabalhos comprovam também que há assentados que compartilham do ideal do Movimento e dos ideais socialistas e que para outros, a coletivização não faz muito sentido, o que não quer dizer falta de solidariedade, assim como há o camponês cristão comunitário.

No meu trabalho de campo no assentamento, em Itapetininga/SP, também é possível encontrar moradores que defendem a construção do socialismo; outros que são profundamente religiosos, trabalham em coletivo, ajudam os vizinhos de acordo com um ideal de fraternidade cristã, mas não se expressam em termos de capitalismo ou de socialismo; e, outros que simplesmente preferem trabalhar para seu sustento e o de sua família. São ambigüidades e ambivalências das falas dos interlocutores. No entanto, quase todos eles se professam membros participantes do MST e/ou se mostram profundamente agradecidos ao Movimento.

Decorre, então, a necessidade de refletir sobre as formas de produção não capitalista. Daí a importância de projetos como o de Boaventura de Sousa Santos, Reinventar a Emancipação Social (2002), que não cai no reducionismo econômico nem culturalista.

Dentre os textos da coletânea organizada por Santos (2002), o de Quijano (2002) insere-se diretamente na discussão acima. Ele sistematiza a questão das formas alternativas (ou não-capitalista) de produção em duas vertentes: a economia solidária e a economia popular. A primeira propõe-se como um modo de produção não-capitalista, cujos princípios são a propriedade coletiva ou associada do capital e o direito à liberdade individual, e tem na cooperativa autogerida seu paradigma. Singer, um dos principais teóricos dessa vertente, a vê como um caminho para a construção de um socialismo que não passa necessariamente pela conquista do poder do Estado (Cf. SINGER, 2002b: 112). Já a economia popular trata de instituições heterogêneas de produção e de relação com o mercado, formada por pessoas que têm relações diretas entre si, e, organizada por uma “lógica comunitária”. É uma proposta especificamente latino-americana e tem em Quijano um dos seus principais teóricos. Ela diferencia-se da economia solidária porque, basicamente, não assume necessariamente e explicitamente uma única visão políticoideológica entre seus agentes.

Dessa sistematização de Quijano (2002), pode-se dizer que nos assentamentos de reforma agrária a produção está mais para a economia popular do que para a solidária, por que não predomina claramente uma visão socialista. Mas, a linha de análise de Singer (2002a; 2002b), que coloca as cooperativas do MST no prisma da economia solidária, é de 
fundamental importância, tanto para os rumos do Movimento quanto para a construção de uma sociedade mais solidária e democrática (quiçá socialista). Voltar-se-á ao texto de Singer mais à frente.

Retomando, Quijano mostra que o debate sobre o $\mathrm{MST}^{20}$ gira em torno das questões da democracia e do socialismo. O autor resolve essas questões ao tratar do problema da democracia. Ele define democracia como uma estrutura de relações sociais na qual todas as pessoas têm controle autônomo sobre seu trabalho, sobre a sua subjetividade e sobre a autoridade coletiva, o que pressupõe um quadro institucional para expressar e praticar tal controle. O Estado-nação não corresponderia mais a esse quadro institucional. Assim, a democracia é condição sine qua non para uma "revolução social". Nesta perspectiva, não poderia existir uma economia alternativa, nem sistemas alternativos de produção, sem uma estrutura de autoridade alternativa ao Estado capitalista. "A democracia requer um contexto no qual o sistema de autoridade apóie a reprodução de um sistema de controle democrático da autoridade" (QUIJANO, 2002: 511-2).

Vamos voltar ao tema da economia solidária como modo de produção socialista. Ao analisar a ressurgimento da economia solidária no Brasil, Singer (2002a) apresenta um breve histórico das cooperativas do MST. As Cooperativas de Produção Agropecuária (CPAs) unificavam os lotes de terra dos membros e trabalhavam o conjunto de acordo com um planejamento. De inspiração cubana, o que implica planejamento nacional e falta de autonomia em relação ao partido-Estado, esse modelo de cooperativismo logo se mostrou incompatível com as expectativas e anseios da maioria dos assentados. Em pouco tempo o modelo como um todo mostrou seu fracasso; no entanto, há casos de CPA funcionando bem (Cf. CARVALHO, 1998; CHRISTOFFOLI, 2003).

O autor sistematiza as motivações de abandono nas cooperativas agrícolas em três: 1) baixo retorno econômico para grande investimento; 2) descontentamento com as formas de retiradas, que não incentivam aqueles que produzem mais e melhor porque são calculadas por horas trabalhadas; 3) insatisfação com o papel do trabalho familiar no coletivo, pois só os adultos são sócios e ganham, e, o pai de família perde o poder de "chefe" (SINGER, 2002a: 111). Os casos analisados nos trabalhos acima, que tratam de cooperativas, encaixam-se neste esquema, apesar de Singer basear-se exclusivamente nos textos de Sizanoski (1998) e Souza (1999).

\footnotetext{
${ }^{20}$ Quijano se refere ao debate entre Navarro (2002) e Carvalho (2002), que será tratado mais à frente.
} 
Para o economista, o relativo fracasso das experiências iniciais de cooperativas nos assentamentos é material para a re-elaboração do modelo e não para o abandono de tal empreitada. O próprio MST, visando uma agricultura moderna nos assentamentos, o que implica um maior grau de cooperação, reconheceu que as CPAs não são desejadas por grande parte dos assentados; então, desenvolveu outras formas de cooperação, como as cooperativas de comercialização ${ }^{21}$. Nestas, a individualidade do camponês é preservada e permite organizar compras e vendas em comum, ajudando também na mecanização da agricultura $^{22}$. Enfim, o MST quer evitar que o assentamento seja dividido entre os que são associados de alguma cooperativa e os que trabalham isoladamente; por isso, criou o Sistema de Cooperativas dos Assentados (SCA), que procura abranger todos os assentados.

Através dele, o MST procura dar aos assentamentos uma estruturação democrática, em que a economia solidária possa avançar na medida em que mais e mais assentados percebam que a cooperação vale a pena e oferece menos riscos que a atividade individual isolada (SINGER, 2002a: 106) ${ }^{23}$.

Neste ponto, os trabalhos de Singer e de Carvalho convergem. Porém, há análises que colocam o ethos camponês refratário ao cooperativismo, a de Miranda (1998), por exemplo. Ela coloca essa refração porque o "cooperativismo" é lido pela autora como estando ligado à lógica capitalista, o que é um equívoco. O ponto importante nesta questão, a forma heterônoma como o cooperativismo foi colocado pela direção do MST aos assentados, confunde-se com o conteúdo político presente no cooperativismo; se a organização do Movimento cria cooperativas com baixo grau de democracia interna não quer dizer que elas não possam ser apropriadas pelos assentados como fonte de emancipação.

O terceiro autor que se propõe fazer generalizações sobre o MST é Navarro (2002). O sociólogo considera insuficientes as análises existentes sobre o Movimento e faz a seguinte classificação dos trabalhos acadêmicos sobre o tema: 1) estudos descritivos das ações do Movimento, de maneira acrítica, que se confunde com a literatura da própria organização; 2) estudos restritos ao âmbito local das ações, geralmente os assentamentos

\footnotetext{
${ }^{21}$ Vale remeter o leitor aos textos que periodizam as etapas das orientações político-econômicas do cooperativismo no MST (Cf. CHRISTOFFOLI, 2000; MST, 1993).

${ }^{22}$ Pode-se contrapor a leitura feita por Singer (2002a) às críticas postas por Schreiner (2002) ao modelo de cooperativismo do MST. Enquanto o último ataca o modelo inicial de cooperativas de produção, o primeiro retrata um vai-e-vem do MST para adequar as propostas de coletivização com os costumes dos trabalhadores rurais.

${ }^{23}$ Cabe destacar que o interesse político-econômico que Singer encontra nas cooperativas, como superação "aqui e agora" do modo de produção capitalista, não é necessariamente compartilhado pelo MST como um todo.
} 
(há grande número de trabalhos existentes); 3) um raro grupo de trabalhos que procuram analisar nacionalmente o Movimento e interpretá-lo com base nos processos sociopolíticos e econômicos recentes (NAVARRO, 2002: 193-4) ${ }^{24}$.

$\mathrm{O}$ autor tece contundentes críticas à organização do Movimento. Segundo ele, a organização é "essencialmente não-democrática", os dirigentes estão "presos à ortodoxia leninista", não são eleitos e não são submetidos à responsabilização interna porque não há canais de prestação de contas (NAVARRO, 2002: 207-17). Dentre vários outros pontos, o sociólogo apresenta dois desafios a serem superados pelo MST: a questão da (falta de) democracia e o problema da gestão nos assentamentos (e sua sustentabilidade). Por fim, com todas essas críticas ao Movimento, mas reconhecendo as conquistas, o autor não vê nenhum potencial de emancipação nele ${ }^{25}$.

Carvalho (2002) foi o responsável, pelo MST, por responder as criticas de Navarro. Ele argumenta que o Movimento tem uma dinâmica nos seus centros de decisão que impede a cristalização da estrutura de poder. Uma das razões está nas ocupações de terras, que são decididas e organizadas por "movimentos de massa local” e, por isso, é impossível passá-las para uma instância organizacional burocrática centralizada. Afirma que o MST não defende mais um único modelo de organização da produção nos assentamentos.

Navarro treplica o texto de Carvalho. Mostra uma incoerência na argumentação de Carvalho que é dizer que o Movimento, ao partir para a ação direta das ocupações sem mais esperar pelo Estado para a realização da reforma agrária, emancipa-se do Estado; no entanto, em seguida coloca que o MST não abdica dos recursos e serviços públicos. Não dá para se emancipar do Estado e, ao mesmo tempo, depender de recursos públicos. Quanto à questão da democracia no interior do Movimento, Navarro vê como um avanço o fato de o Movimento ter aceitado responder publicamente suas críticas.

Vale mencionar, por último, que o MST continua a ser visto como peça importante na luta pelo socialismo no Brasil. Francisco de Oliveira (2000), num texto sobre classes

\footnotetext{
${ }^{24}$ O próprio Navarro (2002: 265-6) não se atém muito a classificação inicialmente proposta, pois, páginas à frente, constrói uma outra tipologia para enquadrar os trabalhos sobre o MST. Nessa segunda classificação, separa os trabalhos em: "encantamento ingênuo" (de estabelecer uma positividade a priori do Movimento) ou de "dogmatismo passadista" (presos a ortodoxia marxista e sem abertura analítica). O autor coloca o seu trabalho num terceiro tipo, que conseguiu atingir o nível da crítica.

${ }^{25} \mathrm{Um}$ dos problemas das críticas ao Movimento feitas por Navarro é colocar o governo de Fernando Henrique Cardoso (PSDB), de 1995 a 2002, como responsável por uma abertura de canais de implementação de políticas públicas, sem precedentes em nossa história. "Por que não foi aproveitada esta oportunidade histórica, talvez única?" (Navarro, 2002: 278), escreve o autor, mergulhado em seu contexto histórico imediato. Em nota anterior, ele explica que o Movimento cometeu uma série de erros em relação ao governo federal, a partir de 1996, quando se recusou a negociar com o, então, Ministério do Desenvolvimento Agrário
} 
sociais em mudança e a luta pelo socialismo voltado para reflexão sobre o PT (Partido dos Trabalhadores), enfatiza que o MST é um exemplo de contratendência em relação a atual fase de expansão do modo de produção capitalista. Para o autor, o Movimento realiza uma fusão entre "operariado rural" e "pequenos empresários despojados". Ai está a radicalidade do MST, sugere o autor. "A radicalidade do MST é dada, um tanto paradoxalmente, pela sua ala de 'proprietários', com o programa da propriedade da terra de forma ampla" (OLIVEIRA, F., 2000: 20). A colocação fica em aberto, para pensarmos.

Por fim, algumas questões devem ser ressaltadas. Sobre a noção de território, uma questão perpassa os trabalhos, a das garantias para ser um território camponês. Para alguns autores, a propriedade é a garantia, para outros é o resgate da cultura (ou ethos) camponesa. Nessa discussão, o conflito no interior de cada fração de território é relativamente destacado, porém, pouca atenção é dada para as "redes", que são tematizadas juntamente com o conceito de território por Raffestin, conforme visto na Introdução. Assim, o que se propõe nesta tese é ver o território camponês como campo de conflitos, que se articulam em redes. Sobre os conflitos internos, há a contribuição da noção das "invalidações recíprocas" e a dos trabalhos que realizam a crítica aos preconceitos contra "camponês" expressos pela cúpula do MST e que mostram a existência de uma diversidade de formas de organização política e econômica no interior dos assentamentos, que ultrapassam as antigas coletivizações "forçadas" pelo Movimento. Conclui-se também que as dissidências internas, ou abandonos de grupos, e os rachas nos movimentos pela terra são importantes formas de gestão de conflitos, ao invés de mera manifestação de "individualismo" camponês. Foi visto que as associações são formas de gestão política e econômica dos assentamentos e que elas mostram melhores resultados em comparação aos "individuais".

Procurou-se, de modo geral, sistematizar e analisar os trabalhos sobre o MST e fazer uma ponte entre as interpretações de casos locais e as teorias gerais sobre o papel do Movimento no contexto das lutas sociais do país. Uma contribuição central dessa revisão é, ao constatar que há conflitos internos comuns aos assentamentos, ver que uma parte expressiva da literatura se atém à idéia de uma essência camponesa, no entanto, há, de outro lado, autores mostrando que a democracia e a gestão cooperada do coletivo são coisas aprendidas e estão por serem construídas. Pode-se dizer que é pela práxis que se

(NAVARRO, 2002: 278, nota 13). O autor segue as mesmas críticas feitas por J. S. Martins apontadas em nota acima. 
poderá chegar a uma conciliação entre o ethos familiar camponês e as formas de produção e/ou distribuição coletivas.

Apresentaram-se os principais debates teóricos sobre a interpretação do MST (Z. Navarro versus H. Carvalho) e sobre o papel no movimento na construção do socialismo (P. Singer e F. Oliveira). Vale notar que as posições de Carvalho e Singer têm mais proximidade entre si do que com Navarro.

Analisar o MST não é o tema específico desta pesquisa. No entanto, para interpretar os conflitos internos em assentamentos é preciso inseri-los num contexto maior que são o da ampliação da luta e o das políticas do Movimento para a gestão e produção nos assentamentos. Interessa aqui o potencial que o cooperativismo tem como emancipação camponesa. Afinal, alguns moradores de rua podem se emancipar como camponeses. A seguir, a empiria será tratada. 


\section{Parte 2 - a empiria}




\title{
Em campo: união, desunião e reunião
}

\begin{abstract}
Porque o trabalho não adoece ninguém. $O$ trabalho ele dá saúde, dá energia. Quanto mais você trabalha, você sente sabor, entendeu? Quando eu não estou para fora, fazendo uns trabalhos lá fora, que eu estou aqui dentro do sítio, que eu estou trabalhando no cabo da enxada... eu uso todas as minhas forças que Deus me dá. Olha ai, o braquearão ai, tudo. Aquilo não foi ninguém que fez, foi tudo eu, fui eu sozinho e minha mulher. Então eu me sinto uma pessoa feliz.

Walter $(5 / 05 / 01)$
\end{abstract}

Este capítulo é o primeiro a enfatizar o trabalho de campo, das primeiras impressões às interpretações, passando pela sequiência de união-desunião e de reuniões. Havia um olhar inicial inspirado pelo trabalho de Urushima (2000): um conflito manifestado na polarização entre aqueles que queriam e os contrários à construção de uma agrovila, ou "individualistas" e "coletivistas", na linguagem usada pelos assentados do MST, como visto no capítulo anterior. O foco recai sobre a dinâmica do assentamento: as pessoas já se conheceram muito bem com a vida em acampamentos, unidas há quase dois anos pela luta em comum. Devido a essa condição de pouco espaço entre elas por causa das condições de luta, querem experimentar ter um local "seu". Com cada família em seu lote, começa um novo movimento, reuniões para formar associações e grupos. O foco nos conflitos entre os assentados, que levam a movimentação e a re-configurações espaciais, vincula-se a uma reflexão sobre o pesquisador-observador e sobre as implicações da pesquisa nessa dinâmica.

Da ocupação da fazenda à desapropriação e demarcação dos lotes, ocorreu uma significativa re-configuração espacial do terreno. Foi o Estado, após controvérsias com os assentados, quem colocou uma malha quadricular sobre a área ao dividi-la em lotes iguais. Vale ressaltar esse aspecto, pois é o ponto de partida das observações de campo. Na figura 4 , visualiza-se a configuração da demarcação dos lotes sobre a área original da fazenda. É com base nessa configuração espacial que se deve pensar aquela fração de território e as redes. Na foto 1 , há um vista geral do assentamento, em que se podem observar as configurações dos lotes com a localização das casas, das áreas de cultivo e das ruas. 


\section{Primeiras impressões e paisagem local}

O trabalho de campo teve início em abril de $2001^{1}$, quando fui conhecer a extensão da área e algumas famílias. Na primeira ida a campo, encontrava-se exposto sobre o balcão de uma vendinh ${ }^{2}$ um pedaço de carne de porco sangrando com moscas ao redor. Um casal de ex-moradores de rua era responsável por aquele armazém, que vendia alguns mantimentos (arroz, feijão, açúcar, óleo) aos demais moradores. Num outro dia, um dos moradores, ao ver o dono do local carregando uma peça de carne de porco recém abatido, comentou comigo que ele estava fazendo coisa errada e que, para minha pesquisa, eu deveria procurar por Carlos, um dos ex-coordenadores da fase de pré-assentamento; deixou implícito que eu deveria fazer isso antes de me voltar para aqueles que vieram das ruas. Deu para ver que o bar-armazém de beira de estrada podia até ser tolerado, mas a venda de carne naquelas condições não.

Voltarei ao tema dessa vendinha ao final do capítulo. Outro aspecto a ser destacado é a paisagem ${ }^{3}$ local. A entrada principal do assentamento é pela direção norte. Adentra-se o mesmo após atravessar uma ponte de madeira sobre o rio Irene, com meandros acentuados neste trecho. Antes da ponte, o relevo é formado por uma planície arenosa, inclusive há locais de extração de areia que são avistados do assentamento, que podem ser visualizados na parte inferior da foto 1 . Vindo de Sapé até se chegar ao rio, atravessa-se uma fazenda de mais de mil hectares com plantio de eucalipto arrendada por uma companhia de papel. Na planície beira rio, há áreas de pasto e algumas chácaras com moradores e outras freqüentadas nos finais de semana.

A estrada principal que corta o assentamento é de terra arenosa. Por ela, segue-se em direção ao sul e, após uma curva onde se acumula areia, a direção aponta para o oeste onde se cruza a porteira da fazenda Santa Luzia, uma propriedade particular de 1160 ha com plantio de eucalipto arrendada por uma corporação que produz papel. Seis lotes próximos à divisa com aquela fazenda são marcados pela presença de tocos de eucalipto e pela necessidade de destoca para qualquer cultivo. A visão mais comum, das beiras da

\footnotetext{
1 Nesse período, contei com a ajuda de Rita Albino que também realizava trabalho de campo no assentamento para seu trabalho de conclusão de curso (ver ALBINO et alli, 2002).

${ }^{2}$ Os termos em itálico são os usados pelos moradores. As palavras estrangeiras também são grafadas em itálico.

${ }^{3}$ O termo "paisagem" é tomado como uma noção comum a diferentes linhas da geografia humana e não como um conceito. Corresponde àquilo que é apreendido através do olhar.
} 
estrada é de pastagens, de cercas divisórias e cercas protetoras de gado ${ }^{4}$ (ver fotos 2 e 3 ), de alguns canaviais para alimentar o gado, de terras aradas para a roça de mandioca e milho e plantações de melancia, arrendada ou em regime de parceria. (A questão do arrendamento será tratada no sexto capítulo). Algumas casas ficam mais próximas da estrada e outras mais afastadas.

O terreno do assentamento é levemente ondulado, com desnível máximo de 30 metros. No foto 3 é possível observar a pastagem de um lote e a ondulação do terreno de alguns lotes. Há variação também na fertilidade do solo. Desse modo, alguns lotes são mais planos outros menos, uns com melhores terras e outros com piores. Levando em conta algumas dessas diferenças, INCRA e Itesp procuraram compensar os lotes em piores condições ao, por exemplo, colocar um poço artesiano abastecendo os lotes onde predominam as soqueiras de eucaliptos, chamados localmente de lotes dos tocos. De acordo com a visão política estatal de que a divisão igualitária dos lotes é justa, nota-se que a igualdade de tamanho não oferece, em si, as mesmas condições de recursos.

As casas foram transformadas nos quatro anos de pesquisa. Inicialmente eram de madeira e localizadas próximas à entrada do lote. Aos poucos, com o financiamento federal de habitação, de 2001 para 2002, surgiram, ao lado das casas de madeira, as de alvenaria. Até o momento, há pessoas que moram nas casas de alvenaria e outras que ainda não terminaram suas casas e continuam na de madeira. É comum encontrar nos lotes a coexistência entre as casas de madeira e de alvenaria. Em alguns lotes, o tamanho e a qualidade da casa mostra-se como um sinal de diferenciação econômica.

Desde 2002, todas as casas possuem luz elétrica, devido ao programa de implantação de infra-estrutura e serviços em projetos de assentamento criados em áreas destinadas à reforma agrária do INCRA com financiamento da Caixa Econômica Federal. Após dois anos de espera e pressões, os assentados conseguiram a instalação de rede elétrica custeada pela metade pelo Ministério do Desenvolvimento Agrário e outra metade paga pelos usuários. Antes disso, havia energia elétrica somente na casa da sede da fazenda e na do antigo caseiro.

A partir de 2004, alguns moradores começaram a colocar uma placa na porteira de entrada do lote com o nome do sítio. Pelo observado, inicialmente um lote colocou tal placa e os demais daquela rua o seguiram. É um indício de um movimento de apropriação

\footnotetext{
${ }^{4}$ Sobre a distinção entre cercas divisórias e cercas protetoras, ou de respeito, ver Castro Oliveira (1991: 99100).
} 
do local: de lote para sítio 5 . Esse é um movimento próprio de florescimento de características do modo de vida camponês. Nota-se a consolidação dos sítios: a casa com pomar, horta e galinheiro próximos e a área de roçado e/ou pasto mais afastada. Ver os desenhos que alguns moradores fizeram de seus sítios, nas figuras 5, 6 e 7. Na figura 5, está representado o tipo mais comum de sítio; na figura 6, uma variação que é a presença de pasto rotacionário e, na figura 7 , destaca-se a estufa.

Como a maioria dos moradores preferiram os lotes individuais, restou de área comum a todos os 4 ha da sede, sem contar os 373 ha de reserva que devem ser mantidos intactos. A sede da fazenda é uma casa com seis quartos, sala de dois ambientes com uma lareira ao centro, cozinha, banheiros e dependências de serviços. Conta com duas edículas, uma com um salão e área de serviço e outra com uma sala. Na área externa tem uma piscina e uma quadra de futebol. A principal idéia para destino daquela casa era ser um centro de formação do MST, onde se abrigariam tanto cursos quanto hospedagem para visitantes. Com este intuito, no primeiro ano do assentamento, a direção do Movimento chegou a colocar dois militantes externos morando na casa. Também funcionou ali, temporariamente, uma confecção de bonés e bandeiras, símbolos do MST. No início do trabalho de campo, a casa era usada pelos assentados para encontros e reuniões.

Em julho de 1999, uma das edículas virou biblioteca comunitária ${ }^{6}$, devido ao trabalho de apoiadores do Clarice Lispector. A partir do final de 1998, uma psicóloga e alguns amigos doaram livros para a comissão de educação do assentamento. Um grupo de jovens moradores organizou-se para formar uma biblioteca e para alfabetizar as crianças. Aquela psicóloga passou a trabalhar com o grupo de jovens no sentido de viabilizar que realizassem seus projetos. Os jovens viraram "mediadores de leitura": aproximavam as crianças dos livros. Contaram com a parceria de algumas instituições e de um colégio particular de ensino médio de S. Paulo. Estudantes desse colégio faziam intercâmbio com os jovens do assentamento. Aqueles visitavam o assentamento uma vez por mês e junto com os jovens moradores, entre outras atividades, liam para as crianças locais livros e revistas que estas escolhiam. Algumas vezes, os jovens do assentamento foram à capital para atividades com estudantes daquele colégio. Esse projeto do colégio durou mais de um ano. O grupo de jovens, formado por umas vinte e cinco pessoas, queria que o assentamento continuasse unido como na época de acampamento. Mesmo quando cada

\footnotetext{
5 Sobre a transformação de lote em sítio como movimento característico de camponeses assentados, ver Bombardi (2001: 181).

${ }^{6}$ Há um vídeo sobre essa biblioteca realizado pela organizadora do projeto. Ver Gebrim (1999).
} 
família foi para seu lote, em 2000, os jovens continuaram se reunindo na sede e superaram as brigas entre seus pais. Dessa união, eles decidiram formar um grupo de teatro no final de 2002. Porém, aqueles que tinham o ideal de trabalho conjunto viram que nem todos participavam do teatro. Então, resolveram continuar com o grupo de teatro visando somente aqueles que se envolveram. O grupo de teatro continua a existir até o presente com cerca de doze pessoas. Um mestre de teatro acompanha mensalmente o grupo, desde março de 2003, com apoio financeiro do sindicato dos psicólogos do estado de S. Paulo.

No ano de 2001, um "grupo de mulheres" começou a se reunir no local para discutir o assentamento e cuidar da sede. O grupo promoveu um reencontro dos assentados, que estavam dispersos em seus lotes, ao organizar festas de aniversários na sede. Assim, as mulheres uniam-se e atraiam os maridos. Essa iniciativa durou alguns meses.

Entre 2002 e 2003, a situação da sede é de abandono. As instalações foram se deteriorando. Ocorreram no local algumas festas, reuniões e assembléias, mas visivelmente o espaço de todos estava sofrendo do mal de não ser de ninguém. Mesmo com a eventual presença de algumas mulheres que se reuniam para fazer pães, com forno e batedeira doados pelo governo do estado, a sede não se mostrava como um local apropriado por todos.

De 2003 para 2004, alguns moradores mais atuantes organizaram uma comissão para cuidar da sede. Começaram um trabalho para cercar o entorno, porque segundo eles o gado suja e estraga a casa, colocaram um padrão para controle de energia elétrica e arrumaram vazamentos d'água. É ainda um espaço público por se realizar.

Como espaço público, o assentamento como um todo, passou por momentos críticos. No segundo semestre de 2003, a ponte de madeira, entrada principal, ficou interditada para veículos por uns dois meses para obra de manutenção na estrutura. Essa obra foi conseguida após uma manifestação das famílias em frente à prefeitura de Irene. Nessa época, a porteira com a fazenda Sta. Luzia foi trancada a cadeado por seus donos. Por coincidência, era uma época em que havia grande quantidade de notícias sobre o MST. O acesso motorizado ao assentamento só era possível por uma estrada secundária que cruza uma grande área do governo do estado para pesquisa e extração de resina de Pinus elliot, chamada de Fazenda do Estado. De repente, aquilo que alguns geógrafos denominam de território camponês, tratado no terceiro capítulo, estava quase isolado. Vale analisar, no sétimo capítulo, essa questão do território, do isolamento e das redes.

Voltando ao andamento inicial, no começo do trabalho de campo procurei diretamente aqueles que eram provenientes das ruas de São Paulo, mais especificamente 
queria encontrar Walter. No início de 1998, tive a oportunidade de visitar o acampamento junto com membros e simpatizantes da Fraternidade Povo da Rua. Semanas depois dessa visita, houve a desapropriação da fazenda. Naquele dia pude ouvir depoimentos, conhecer alguns dos acampados e ver a horta comunitária. Entre as pessoas que me chamaram a atenção, uma delas foi Walter pela sua visão política e pela fala articulada e memória da luta. Portanto, ele foi uma das primeiras pessoas a ser entrevistada, após serem criadas as condições de confiança mútua. As quatro horas de entrevista gravada confirmaram minhas impressões e os depoimentos dados por ele serviram de referência para todo o período de trabalho de campo, pois foram tratados todos os aspectos de interesse da pesquisa (Cf. JUSTO, 2001).

A primeira entrevista com Walter revela uma paisagem de relações sociais em transformação. Ele nasceu em 1944, é natural de Tabaiana Grande/SE. Depois de assentado, casou-se com Ema, que conheceu fazendo trabalho de base. Não possuem filhos. Criado por lavradores rendeiros, ajudava os pais na lavoura quando criança. Em 1962 entrou para o exército na cidade de Santos/SP, e acreditava num país mais justo. Quando houve o golpe militar de 1964, era sargento do exército e foi preso, acusado de ser comunista. Sofreu torturas e ficou recluso junto com outros colegas. Segundo contou, um grupo uniformizado e encapuzado os libertou e os levou para o meio do mato, no estado de São Paulo. Walter saiu andando sozinho, foi para o estado do Mato Grosso e, mais tarde, chegou ao Paraguai onde morou por dois anos. De volta ao Brasil, em 1966, conseguiu obter um documento de reservista do exército. Em 1969, tornou-se metalúrgico. Trabalhou por vinte de dois anos como metalúrgico em indústrias automotivas, como Volkswagem, Ford e Mercedes-Benz. Era militante de grupo socialista trotskista na clandestinidade na década de 1970. Participou do movimento sindical que deu origem ao Partido dos Trabalhadores (PT), em 1980. Perdeu empregos por ser considerado agitador político. Militou também no movimento para moradia dos "sem-teto", participando de ocupações de imóveis. Sem conseguir mais colocações como metalúrgico, partiu para a construção civil até não obter mais nenhuma fonte de renda. Ficou morando por dois anos nas ruas da cidade de São Paulo até haver o encontro com os membros da Fraternidade Povo da Rua. Através desta entidade, entrou para o MST e conseguiu ser assentado.

A configuração de seu lote, que já denominou de sítio, é a seguinte: entre a porteira e a casa, há um pomar com frutíferas variadas e plantas "medicinais"; o casal mora na casa de alvenaria que Walter ergueu sozinho e mantiveram, ao lado, a casa de madeira como depósito; atrás da casa tem horta e outras frutíferas; na lateral da casa de madeira tem uma 
área de roça, onde ele cultiva feijão, mandioca, milho e amendoim, e, tem um galinheiro cercado próximo a porteira. No restante do sítio, que é a maior parte, há áreas cercadas para gado e para lavoura. Em 2002, chegou a ter 10 cabeças de gado, mas vendeu. Posteriormente, alugou o pasto, fez parceria para plantio de melancia em 5 ha, em 2003, e, em 2004, plantou cerca de 4 alqueires de mandioca para venda em projeto da associação.

Sobre a militância política do Movimento interna e externa ao assentamento e sobre a situação no local, ele pensa o seguinte:

Porque tem o socialista e tem o individual. $\mathrm{O}$ individual vive a vida dele, tal, tem o lado dele, mas ele não quer saber. Ele sempre está no meio da luta para cumprir um papel que ele está atrás para ajudar. Quer dizer, isso aí faz parte do processo agrário. Então esse é um militante sossegado. Agora tem aquele militante que é mais envolvido. É um militante, igualmente a mim, que fica dias a dias atento. (...)

Depende é de você ter a capacidade de entender o que é uma luta de classes. Porque você entendendo o que é uma luta de classes, você arregaça as mangas e vai para a luta de classes de verdade, ter consciência politicamente agrária. (...)

A gente que ama uma luta de classes, que quer ver um país liberal, um país livre, formado, com consciência politicamente agrária, luta por esse lado. Não interessa. Pode ser branco, pode ser preto, pode ser o que for, desde que ele se entregue a uma aliança agrária; que ele quer fazer aquilo, realista, ser uma coisa bonita, sem mentira, honesta, acabou... (...) Porque eu como feijão com farinha pura, mas não quero nada que é de ninguém. Quero aquilo que Deus me der, aquilo que é meu. Porque eu me sinto envergonhado se eu tirar um centavo de um irmão, porque se eu tirei aquele centavo de um irmão, eu tirei aquele centavo do filho dele. É um pão que eu tirei da boca do filho dele. Então se eu puder dar, eu dou, mas tirar não. Então é isso que eu falo sempre na sociedade e eu estou me sentindo angustiado porque no meio de nós já está existindo esse tipo de gente. Esse tipo de gente corrupta, sem vergonha, mentirosa. Que na frente do Movimento Sem Terra é uma coisa e por detrás é outra. É por isso que eu sempre falo sempre na reunião, falo para nossos companheiros: "muito cuidado gente, que nós estamos criando cobra. Criando cobra para futucar nós na frente, nós que somos realistas".

O depoimento oferece uma primeira interpretação do assentamento. Para ele, o individualismo é um problema central no local. Dentro desse posicionamento, haveria possíveis "traidores" da luta, aqueles que estão voltados somente para o seu lote e não se preocupam com os interesses coletivos. Walter preocupa-se porque os "mentirosos", que não seguem aquilo que ele considera ser a verdade, podem destruir a luta no assentamento. É importante essa reflexão de Walter, porque foi expressa num momento em que os 
maiores conflitos no assentamento ainda não haviam eclodido, como será visto no capítulo seguinte.

Sobre a continuidade da luta, ele reforça sua posição política contrária ao individualismo e afirma-se como um militante exemplar.

Vou a todos os encontros. Vivi mais para fora, fazendo marchas nacionais, marchas estaduais. Fazendo um trabalho de base, de Frente de Massas ${ }^{7}$, para reforçar mais ainda as lutas. Eu nunca parei aqui dentro, nem sequer seis meses. Até esses dias mesmo, eu estive citando com a minha esposa, falei para ela: 'se eu adivinho que depois do cara assentado, ia ter comodismo demais, eu não queria nem ser assentado aqui dentro'. Eu ia ficar, nem que eu esperasse mais dez anos, ia assentar. Só que não é que eu estou amarrado por causa dessa porcaria, que isso aqui não é meu, isso aqui é do povo, é da comunidade [o lote onde está assentado atualmente]. Quem quiser dizer que tem terra, que fale, mas eu só falo que isso aqui é uma comunidade. Sou consciente daquilo que sempre lutei. (...) Quando eu não estou para fora, eu estou aqui dentro do sítio, estou trabalhando no cabo da enxada (...) Quando eu saio, que eu estou com as comunidades, com a sociedade, o nosso povo de rua, eu me sinto feliz. Porque eu sei que estou no meio daquele meu pessoal.

Para exemplificar sua posição, Walter disse que há, naquele momento, dois coletivos $^{8}$ no assentamento, um em que ele participaria e o outro que é o de Carlos e seus familiares. Perguntado sobre o que é "coletivo", respondeu que é plantar coletivo, é criar o gado junto. Voltou-se para o fato de o coletivo de Carlos ser formado pelos filhos e suas famílias e também pela família de Vladimir. O grupo do qual Walter fazia parte - naquele momento - era de "famílias rachadas, que não têm nada a ver uma com a outra", seria assim "um coletivo realista". Coletivo é a horta que cuidam juntos, o gado é comum; há o plantio individual nos lotes para sustento da casa e, em outra parte do lote, planta-se coletivamente.

Chama a atenção a sua narrativa a seguir, porque explicita que - naquele momento [2001] - ele estava investindo num trabalho coletivo com Rosa (uma das ex-coordenadoras

\footnotetext{
${ }^{7}$ Frente de Massas é uma instância da organização do MST, considerada a porta de entrada das bases no Movimento.

${ }^{8}$ Coletivo é um exemplo de linguagem da organização do MST incorporada pelos assentados. O Movimento chama a atenção para o fato de que todo grupo de assentados que resolve fazer algo em conjunto passou a ser chamado de coletivo. Mas, para o MST "coletivo" em geral é um grupo pequeno de poucas famílias (no máximo 10), que reúne vizinhos, parentes e amigos, com o objetivo de fazer algo simples em conjunto (Ex: comprar trator, adubo ou calcário, ou fazer uma benfeitoria); a terra é trabalhada individualmente e não tem estatuto (Cf. MST. A Cooperação Agrícola nos Assentamentos. Cadernos de Formação No. 20. São Paulo: MST, 1993, pp. 26.) Para distinguir "coletivo" de "grupo de produção coletivizada" ou "semicoletivizada", ver MST/ Concrab. Questões Práticas sobre Cooperativas de Produção. Cadernos de Formação No. 21. São Paulo: MST, 1994, pp. 14-17.
} 
do assentamento), com quem iria romper meses mais tarde para formar outro grupo; ele coloca-se como aquele que tem consciência política e que a leva para os demais:

Como eu estou com essa área aqui que está dividida e é onde eu vou fazer a minha casa lá em cima. Na área coletiva vamos plantar feijão. No lote da Rosa vamos fazer horta e o nosso gado está lá. E depois todos têm o seu individual. Pode criar uma galinha, um porquinho ou até um bezerro para o sustentado, para quando quiser fazer um churrasco individual. As famílias são boas. Estão aí se preparando. Eu estou a ver se consigo formar esses companheiros, para ver se se formam no coletivo. Estamos começando as coisas. Mas para isso temos que ter consciência... Politicamente... Saber levar, não ficar explodindo, se esparramando com os companheiros. Democraticamente lutamos para que todos tenham os seus direitos, sem escravidão. Se formos exigir desse povo... Aí é ditadura. E não pode. Os companheiros têm direito de escolher aquilo que é melhor. Fazemos o papel. Porque tem aquele ditado: - 'Se você quer o povo, mostra a tua base, faz, não manda ninguém fazer'. É isso que fazemos aqui dentro. Aí aquele povo vê a realidade. Vê onde está a verdade. Porque não adianta eu mandar a pessoa fazer e eu não fazer, eu mandar a pessoa fazer e eu fazer diferente. Assim está errado. E a pessoa nunca vai se conscientizar.

Pelo seu posicionamento político, Walter é capaz de fazer e desfazer laços. Ele foi coordenador de ética na fase de acampamentos e manteve-se unido aos coordenadores da fase de pré-assentamento. Em 2001, Walter é o único ex-morador de rua que ainda se mantém unido a um grupo, ou coletivo. No meio de 2002, já havia rompido com aquele grupo e começa a formar um grupo com outros que vieram da rua, os "Exculhidos". Passou, então, a atacar aqueles com quem havia se unido. Essa rede rompeu-se e uma nova foi armada. Entre 2003 e 2004, a rede dá origem a uma associação, Compartilha. Ao longo dos anos de pesquisa, Walter mostrou habilidade de fazer e romper com alianças. $\mathrm{O}$ estudo dessa e outras redes e organizações no assentamento será apresentado no próximo capítulo.

O posicionamento de Walter precisa ser visto em relação a três ex-coordenadores do assentamento. Assim, será possível compreender as redes e conflitos no assentamento. Há no Clarice Lispector três pessoas que foram coordenadores e que se destacam, são Carlos, Frederico e Rosa ${ }^{9}$.

Carlos e família são do norte de Minas Gerais. Ele era meeiro nas terras de um prefeito e participou da organização do sindicato de trabalhadores rurais e da fundação do PT na sua cidade natal. Em 1986, colaborou em ocupações organizadas pelo sindicato em Virgulândia, norte de MG. A família mudou-se para o Paraná, por um ano, e depois para

\footnotetext{
${ }^{9}$ Há um quarto ex-coordenador que não participa ativamente da vida em comum no assentamento. Será identificado em situação oportuna.
} 
três lugares distintos em S. Paulo. Quando entraram para a luta do MST, estavam morando em Sorocaba. Durante esse percurso, Carlos conseguiu trabalhar como lavrador a maior parte do tempo. Nos dois anos que morou em Sorocaba, antes de entrar para a luta pela terra, trabalhou numa revendedora de caminhões como ajudante de pedreiro e preparava o solo para ser gramado. Junto com Carlos, esposa e filhos jovens foram para a luta pela terra e também os filhos adultos, um com mulher e filhos, e todos conseguiram ser assentados. Ao todo são oito filhos que moram no assentamento. Desse modo, a família extensa de Carlos envolve sete famílias nucleares ${ }^{10}$, que moram juntas na pequena "agrovila" no lote de uma das filhas, e possuem 6 lotes. Durante os acampamentos, um filho de Carlos casouse com uma filha de Álvaro Filho e esta família nuclear e a do cunhado de Álvaro Filho estabeleceram uma aliança de compadrio - vivem no mesmo lote e trabalham juntos. Em 2003, uma filha de Carlos casou-se com o filho de outro assentado e com isto, há mais uma família e um lote formando um único grupo. É uma união familiar que desde o início do assentamento vem investindo, além da constituição de sítios, na produção de pimentões em estufas. No capítulo seguinte, esse grupo será estudado.

Mesmo não sendo mais coordenador, Carlos é uma referência dentro e fora do assentamento. Afinal, mobiliza sete famílias entre filhos e compadres, sem contar outros pontos de sua rede. Em seu rosto, estão expressos os ideais de ligação com a terra: o trabalho unindo a família, a prática e os símbolos católicos e o silêncio de quem observa e trabalha muito.

Frederico e família são de Minas Gerais. Ele e a mulher estavam morando na região de Campinas quando foram para a luta pela terra. Seus dois filhos casados vieram com a luta em andamento, durante a fase de acampamentos. São, portanto, três famílias nucleares em três lotes, que trabalham juntas. A família nuclear de um filho mora num lote e Frederico, esposa e a família de outro filho moram em outro lote. Um terceiro lote é usado para pasto e lavoura e não para moradia.

Frederico, apesar de ter passado pela cidade, tem longa experiência de vida na roça, de militância na CPT e de participar de associações de produção agrícola. Não participa do grupo das estufas, mas defende Carlos, seu vizinho e amigo. Diz que se os coletivos (grupos das estufas) são compostos por famílias, então também teria um. Desde o final de

\footnotetext{
${ }^{10}$ Basicamente, o termo "família nuclear" se refere ao casal com filhos ou não, que moram na mesma casa, e o "família extensa", ao casal mais filhos casados e/ou avós, tios e sogros (ou compadres), em casas distintas. Para uma análise sobre os tipos de famílias em assentamentos do MST no estado de SP, ver o trabalho de Rapchan (1993), que tem como base a teoria de Chayanov (1974) sobre a importância da família na economia camponesa.
} 
2003, foi chamado pela sua rede de amigos para presidir uma associação de produtores rurais. A organização existente engloba 12 famílias, sendo que duas destas pertencem também aos grupos das estufas.

Rosa, Franco, os dois filhos, uma nora e uma tia moram no lote vizinho a Carlos. Ela e o marido são primos e nasceram na fazenda Timboré, em Andradina/SP. Seus pais lutaram pela desapropriação da fazenda Primavera, no final dos anos 1970, um dos berços do MST no estado de SP (Cf. FERNANDES, 1996: 85-134). Têm quatro filhos, sendo que dois moram na cidade. Foram de Campinas, onde Franco trabalhava numa fábrica, para a luta do MST em nome dos ideais de trabalhar na terra, produzir e viver unido, ter uma vida voltada para a fraternidade cristã entre os assentados. Essa face de Rosa fez com que ela ajudasse aqueles que chegaram das ruas e, posteriormente, se ofendesse quando foi atacada por alguns deles.

Além do núcleo familiar de Rosa, a família de seu irmão e de sua cunhada também estão assentados no Clarice Lispector em lotes respectivos. Formam um coletivo que trabalha com estufa de pimentão e roça em comum nos lotes.

Há uma outra família extensa, a de Aparício e suas duas filhas casadas e assentadas. São mais três famílias e três lotes que se juntam a uma quarta família, sem grau de parentesco, e formam mais um coletivo de produção de pimentões em estufas. Na figura 8 é possível visualizar a distribuição dos lotes com parentes assentados, em que cada cor representa uma família extensa.

Os três Carlos, Frederico e Rosa formam uma rede de 24 famílias conectadas, mais da metade do assentamento, pois somam-se dois grupos com interfaces, como um nó de rede (no caso como são duas famílias, são dois nós). O que, para alguns, os torna um alvo de ataques. Cansados dos ataques, essas famílias e seus aliados, atualmente, querem se proteger e vêem os atacantes como inimigos definitivos. Os grupos e associações, assim como as redes, serão tratados no próximo capítulo.

\section{União e desunião como tensão}

A união inicial no acampamento na fazenda Monte teve um tempo e começou a se fragmentar com a vontade de ter um lote da família. Após mais ou menos dois anos de cada família estar no lote, formaram-se duas associações e um grande grupo de produção em estufas.

Aquela primeira união era remanescente de um ano e meio de acampamentos, portanto, havia também tensão da convivência e da proximidade forçada pela afinidade da 
luta em comum. Algumas vezes, esta era a única afinidade entre vizinhos de barraco de plástico preto. Como muitos relatos colhidos em campo apontaram, durante o tempo de convivência nos acampamentos é possível conhecer muito uns aos outros e, conseqüentemente, formar grupos de afinidade e inimizades. Com a ocupação da fazenda, as famílias organizaram-se na produção de uma horta comunitária, além das comissões responsáveis pela gestão do assentamento ${ }^{11}$. Uns meses depois da desapropriação, em 1998, havia um grupo de cerca de 30 famílias trabalhando coletivamente numa estufa de pimentões. Próximo a esse local, formaram uma agrovila ${ }^{12}$, onde atualmente é o lote número 1. Temos uma união que dura de fevereiro de 1998, com a ocupação, a janeiro de 2000, com a divisão e sorteio dos lotes. É uma união tensa, pois havia vontade de ir para o lote e disputa pela liderança do assentamento. Nesse momento, em torno de 1999, a grande maioria dos assentados une-se contra as posições de Carlos, seus familiares e de Rosa. É o chamado grupão, que expressa a posição de cada um no seu lote contra o trabalho coletivo e a moradia em agrovila defendida por Carlos e familiares. Nesse grupão, reuniram-se pessoas que atualmente defendem posições antagônicas. Frederico e Rosa deixaram, nesse momento, a coordenação do pré-assentamento, ficando somente Carlos como coordenador geral. Pela memória de Frederico, no grupão estavam todos menos ele, Rosa e Carlos e seus respectivos familiares e havia uma pessoa que disputava a liderança deste referido grupo que queria expulsar Carlos do assentamento. Frederico colaborou para que Carlos não fosse expulso; houve também o apoio de um advogado ligado às questões rurais da Ordem dos Advogados do Brasil (OAB) para contornar a situação. Carlos largou a coordenação. Em 2000, como foi relatado na Introdução, cada família vai para seu lote. Carlos junto com seus familiares e compadres formam uma mini agrovila, num dos lotes da família e trabalham juntos nos demais lotes. A primeira estufa de pimentões foi transferida para o lote da família de Carlos. Duas ou três famílias, baseadas em ideais de comunhão, continuaram a trabalhar junto com as famílias de Carlos ou de Rosa, até meados de 2001.

Vale observar que moradores entrevistados que lavraram na primeira estufa (entre 1998 e 1999) percebiam o trabalho como sendo para Carlos, que os remunerava por hora

\footnotetext{
${ }^{11}$ A organização nos acampamentos e assentamentos baseia-se na orientação do MST de se formar setores, ou comissões, com trabalhos específicos: produção, saúde, educação, comunicação, segurança, cultura etc. No organograma das comissões há somente os postos de coordenador e de membros. Geralmente, os coordenadores das comissões formam a coordenação do acampamento ou assentamento (Cf. FERNANDES, 1996: 83).

${ }^{12}$ As casas concentravam-se numa área de uns 20 ha, mas não ficavam muito próximas umas das outras, permitindo plantações ao redor. Essa configuração espacial é bem distinta da atual em que há lotes por toda a fazenda.
} 
trabalhada $^{13}$, e não como uma atividade coletiva. Depois que deixaram o trabalho, passaram a reclamar dos pagamentos efetuados por Carlos. Além de demonstrar o final da liderança efetiva de Carlos, tal fato mostra que o trabalho de criar "coletivos" é um processo que depende de um aprendizado envolvendo transparência e democracia.

Com a disputa pela divisão dos lotes, os coordenadores abandonam seus cargos. Situação que se mantém até o presente. Perdurou por mais tempo uma comissão de saúde (da ocupação até 2002), porém sem ter um papel de gestão do assentamento.

Do segundo semestre de 2001 até a metade do ano seguinte, o assentamento é marcado pelo recolhimento. Os moradores estão voltados para a vida em seus lotes. A falta de união reflete-se no abandono da sede.

De 2003 para 2004, formaram-se grupos e associações. Após, cada família sentir-se consolidada no lote, muitas delas retomaram a reunião de grupos. Há duas associações e os grupos que trabalham em estufas, conforme referidos acima.

Pelo observado em diversos trabalhos sobre o tema, discutido no capítulo três, há um ritmo de união-desunião e reunião comum aos assentamentos de reforma agrária. Portanto, há uma movimentação comum nos assentamentos de formar e romper com alianças, tecer redes com nós fortes e fracos. Neste trabalho pretende-se mostrar a peculiaridade das redes no Clarice Lispector, visto que o período de trabalho de campo registrou a passagem da desunião para re-uniões.

O conflito inicial manifestado na polarização entre aqueles que querem e os que não querem a agrovila, ou "individualistas" e "coletivistas", na linguagem de alguns assentados, desdobrou-se em recurso à arbitragem estatal. Esse desdobramento será estudado no sexto capítulo. Por enquanto, vale observar que os moradores encontram formas de negociar entre si os conflitos, além de procurar pelo poder estatal.

\section{A vendinha: habilidade política de gerir conflito}

O casal Jonato e Jandira são os proprietários da vendinha. Os dois foram moradores de rua em S. Paulo. Eles conheceram-se na fase de acampamento, casaram-se e têm uma filha. Antes de entrarem para a luta na terra, os dois estavam vivendo pelas ruas de S.

\footnotetext{
13 Os assentados receberam uma doação de uma simpatizante, que foi repassada por membros da Fraternidade Povo da Rua para o controle de Carlos. Quando visitei o acampamento na fazenda Monte em 1998 foi por ocasião dessa doação feita.

Sobre o fato de os moradores se perceberem como trabalhando para Carlos, vale mencionar que é comum no universo camponês um trabalhar para o outro sem caracterizar uma relação capital-trabalho. Ver o texto de Woortmann (1990), que aprofunda a discussão sobre as relações de trabalho (ou de ajuda) pago no mundo da "campesinidade".
} 
Paulo. É possível retratar a delicada história dessa vendinha porque houve um desfecho que a retirou da irregularidade. Temos um exemplo de gestão de conflito de forma pacífica e sem recurso ao controle estatal.

Jonato, o marido, nasceu em 23/04/1951, em Resplendor/MG, onde seu pai tinha um pedaço de terra. Quando ele tinha doze anos, seu pai vendeu a terra e a família mudouse para Vitória/ES para trabalhar na roça. Ele trabalhou como servente e como pedreiro quando tinha 19 anos. Então, foi para S. Paulo trabalhar como pedreiro; era solteiro ainda. Voltou para Vitória e, depois, retornou a S. Paulo, onde se casou, em 1980. Sua primeira mulher era de Alagoas, então foram para lá e ficaram doze anos. Mais uma vez em São Paulo, trabalhou por sete meses até retornar para Maceió/AL, onde se tornou mestre de obras e ajudou a construir um shopping center e muitos de edifícios. Quando terminou não encontrou mais serviço, voltou de vez para S. Paulo, em 1996, só com as roupas do corpo, pois deixou tudo para a ex-mulher. Chegou na rodoviária e procurou emprego pelos anúncios de jornais. Só conseguia colocações temporárias, nenhum emprego fixo. Dormiu por três noites na rodoviária, onde uma pessoa the indicou um albergue. Conseguiu autorização para ficar por trinta dias no albergue. Na expectativa de conseguir uma vaga de gari da Prefeitura, prorrogou sua estada no albergue por mais trinta dias; porém, não conseguiu o emprego imediatamente por problemas de visão. Foi quando encontrou o grupo que organizava as pessoas para entrar no Movimento. Começou a freqüentar a Igreja do Brás e participar das reuniões com o padre, que explicava sobre a luta pela terra. Logo interessou-se em conquistar seu pedaço de terra e perguntou o que deveria fazer para tal. Disse a um dos organizadores da reunião que só tinha as roupas do corpo e daquele jeito que se encontrava, queria ir para um lote de terra; ele lhe respondeu que deveria participar de 6 a 7 reuniões. Jonato quis seguir assim mesmo, tendo participado de duas reuniões apenas. O coordenador o colocou na ocupação daquela semana, mas lhe avisou que ele devia estar preparado para não desistir. O padre queria que ele contasse como era a vida na rua, mas Jonato respondeu que não sabia dizer porque ficou no albergue. Aquele, então, teria lhe dito que mesmo que tenha ficado só um dia na rua, "é da rua".

Jandira, a esposa, nasceu em 04/05/1968, em Sirinhaem/PE. Conta sua trajetória do seguinte modo. Nasceu em Sirinhaem, mas seus pais são de Alagoas. Ela e o primeiro marido tiveram dois filhos. Foram para S. Paulo, mas não deu certo e se separaram. Trabalhava em casas de famílias. Quando perdia o emprego, não tinha lugar para ficar, então uma colega lhe indicou o albergue para onde foi. Chegou a ser internada por problemas mentais e perdeu a guarda dos filhos. Depois, começou a participar das reuniões 
com o padre da Fraternidade Povo da Rua e se cadastrou como interessada em participar na luta pela terra. Pernoitar na rua, disse que foi só uma vez. Dormiu no albergue por três meses, mais ou menos, depois passou a freqüentar as reuniões. Entrou para a luta porque ficou com esperança ao ver um vídeo com as lavouras de outros assentamentos. Como assentada, conseguiu reaver a guarda dos filhos.

Em 2002, o casal Jonato e Jandira e os três filhos estavam morando no lote, numa casa de madeira e a vendinha funcionando no fundo da casa. Entre as cláusulas do contrato entre o INCRA e os assentados, uma delas estabelece que não é permitido ter ponto comercial no lote. Jonato diz que ela estava escondida virada para o fundo do lote por causa da físcalização do órgão federal, pois seus "inimigos" o denunciaram. Portanto, ele não queria tratar desse assunto. A situação é ambivalente, os moradores compram produtos (pó de café, açúcar, cigarros, cachaça etc.) e alguns deles condenam a irregularidade e cobram uma ação controladora do INCRA. Jonato não vende mais carne de porco, mesmo assim sofre pressão para que não tenha um estabelecimento comercial dentro do assentamento.

No ano seguinte, 2003, ocorre um desfecho, quando Jonato e família ocupam uma área fora do assentamento, à beira do rio e próxima à ponte de entrada no assentamento, com algum consentimento dos demais assentados. Segundo contou, a área pertence à fazenda Monte; portanto, deduz ele, também pertence aos assentados. A posse é consolidada com a construção da vendinha e de uma casa para a família. Frederico trabalha como pedreiro para Jonato.

Nota-se que Frederico foi um dos articuladores dessa manobra de retirar o bar da área demarcada do assentamento. Ele pressionava para que o bar não permanecesse no assentamento, mas manteve uma relação amigável com Jonato e foi um dos que o apoiaram na ocupação da área para onde mudou a vendinha. Frederico diz que é bom que o bar fique ali porque, além de não estar mais no assentamento, pode cuidar daquele local que é beira de rio e entrada para o Clarice Lispector. Enfim, Frederico mostrou habilidade política ao obter um desfecho para uma situação de irregularidade no assentamento de forma pacífica e amigável a ponto de conseguir o que queria, trabalhar para Jonato na obra e este ficar satisfeito.

Atualmente, a vendinha é um ponto de encontro entre os moradores e os vizinhos do assentamento. A satisfação do casal Jonato e Jandira está estampada em seus olhos, que recuperou algum brilho em comparação ao baço que tinham no início do assentamento. No lote, têm uma casa de madeira, uma de alvenaria em fase de término, um galinheiro e dez 
cabeças de gado. É de se notar que há injeção de dinheiro do bar na construção da casa de alvenaria. No entanto, sentem-se ameaçados porque são acusados de não permanecer nem cuidar do lote e há pessoas interessadas na lista de espera. A fiscalização do INCRA cobrou cuidados com o lote, como fazer horta e pomar e corta o mato.

\section{Primeiras interpretações e a presença do pesquisador}

Como não há uma coordenação geral do assentamento, aparece em alguns conflitos uma disputa pela liderança. Walter, por exemplo, chegou a afirmar recentemente que a briga ali é política. Afinal, ele expressa uma posição política de confronto com os grupos encabeçados por Carlos, Frederico e Rosa. Durante as reuniões dos "Exculhidos”, Walter e outros reclamaram que são tratados como excluídos. No entanto, Walter coloca sua posição política como sendo a única a ser seguida, porque é "a verdadeira", e com isso discrimina aqueles que não ressoam o mesmo tom. Ele une e desune aqueles que vivem sozinhos.

A valorização que Frederico, por exemplo, tem pelo trabalho em família faz com que ele trate os assentados solitários como fadados ao fracasso. Alguns entrevistados disseram que ele dizia que não dá certo homem sozinho no assentamento. Ele interpreta que a capacidade (ou não) de estabelecer-se no lote (de ser camponês, poderíamos dizer), está intimamente ligada ao esforço do trabalho e à disponibilidade de força de trabalho familiar.

Há um confronto de interpretações. Walter e Frederico estão, indiretamente, disputando pela autenticidade de ser camponês, de ser um assentado produtivo e de ter o caminho para a continuidade da luta na terra. Para um é a militância, os ideais políticos e as tentativas de organização de grupos, para outro é o trabalho no sítio e a organização de grupos. Walter é o trabalhador que se esforça para arar a terra no braço e plantar com a mão e, por isso, não é possível trabalhar em todo o lote. Ele coloca-se como quem está longe de ser "vagabundo", porém, é o primeiro a taxar os outros de "vagabundos". Ele nasceu e trabalhou na roça com os pais, em Sergipe. Porém, sua formação política é urbana, da luta sindical metalúrgica da região do "ABC paulista", foi militante da Convergência Socialista. Ao criar a associação Compartilha, abriu-a para trabalhadores rurais e urbanos, pois defende a união da luta dos trabalhadores. Com isso, diz-se o verdadeiro lutador pelo socialismo, pelo fim da luta de classes. Ele legitima-se como verdadeiro merecedor da terra como local de se lutar contra a exploração e expropriação burguesa. Logo, vê-se como legítimo trabalhador (rural). 
Frederico tem uma formação política via CPT. Mesmo tendo passado pela cidade, pela região de Campinas, é um histórico camponês mineiro. Tem uma legitimidade como liderança, como presidente de associação e como gestor de conflito como o do bar.

Outro ponto interpretado pelos moradores foi a dificuldade de participação num grupo formado predominantemente por familiares. Alguns moradores interpretam a desagregação do primeiro grupo existente pelo predomínio de relações familiares. Vladimir entrou para aquela luta pela terra como militante do MST e defendeu o trabalho coletivo. Participou do grupo de Carlos até 2001. Segundo ele, não deu para continuar no grupo porque os laços familiares pesaram na hora de tomar decisões e como ele não era da família sentia que os rumos deveriam ser outros. A partir de então, passou a se dedicar ao seu lote para sustentar a sua família e não participou mais de nenhum grupo. A trajetória de Vladimir será retomada no próximo capítulo. O fato de o trabalho familiar ser definidor da atividade camponesa e no caso tratado ser também um problema para a consolidação de um grupo mais amplo deve ser analisado no final do trabalho. A questão que chama a atenção é a ambivalência dos laços familiares como fator de união e de desunião.

Ao longo do trabalho de campo, durante minha presença no assentamento, tentei que os assentados encontrassem um modo de se apropriar do meu trabalho, mantendo meus temas de interesse. Após meu exame de qualificação, em dezembro de 2003 fiz uma apresentação para eles na sede da fazenda. Compareceram duas famílias, com as quais pude discutir as formas como os conflitos internos estavam sendo conduzidos. A intenção era dar um retorno daquilo que foi observado. Essa preocupação em dar retorno ao pesquisado consolidou-se também quando entreguei a Walter uma cópia do trecho publicado na internet da nossa entrevista e o li para ele.

Paralelamente, algumas situações dilemáticas acompanharam a pesquisa. Como retratar os casos temáticos do trabalho quando as pessoas envolvidas não querem que a situação seja exposta? O caso da vendinha, por exemplo, pôde ser retratado porque houve um desfecho em que não acarretaria mais possíveis medidas punitivas para os donos, que não queriam que o bar constasse da entrevista com eles.

Mesmo o fato de enfocar os ex-moradores de rua, cuja intenção era valorizar sua capacidade de superar uma dada condição, mostrou-se como ponto problemático. Um exmorador de rua recusou-se a dar entrevista porque não queria ser identificado como tal. A 
pesquisa, neste caso, era vista por ele como um problema na reconstrução de sua identidade: de morador de rua para assentado. Tive de lidar com o fato de alguns moradores procurarem deslegitimar os depoimentos de ex-moradores de rua como representantes da realidade do assentamento. Meu recorte estava soando como se uns fossem mais dignos que outros de serem ouvidos.

$\mathrm{Na}$ perspectiva de que a pesquisa pode ser utilizada pelo pesquisado e que o papel de pesquisador é também de contribuir, a partir de um conhecimento específico sobre verdade e poder, para a luta do grupo estudado, após três anos de trabalho de campo tive a oportunidade de ser chamado pela primeira vez para colaborar numa reunião de mulheres ligadas aos grupos dos ex-coordenadores, no início de novembro de 2004. Essa reunião tratou de um caso específico de abandono de lote em que houve tentativa de venda do mesmo e um grupo de jovens do assentamento procuraram garantir o direito de ficar com o lote de acordo com uma lista de espera validada pelo INCRA. Esse caso será tratado no capítulo seis. As mulheres decidiram que se o INCRA não desse o desfecho esperado reaver a posse do lote e repassá-lo ao candidato da lista de espera -, elas iriam à superintendência regional de S. Paulo para pressionar que o órgão cumpra seu papel e resolva as situações irregulares que ocorrem no Clarice Lispector, como a tentativa de venda de lotes e arrendamento. Caso viesse a ocorrer essa ida ao INCRA, elas haviam atribuído a mim a possibilidade de colaborar - através de supostos contatos - acionando os meios de comunicação para dar cobertura ao episódio, como uma necessidade estratégica dentro da lógica conhecida do Movimento de pressionar o governo. Aceitei tal papel e percebi que minha participação estaria restrita àquilo, porém, aproveitei para falar de algumas observações da pesquisa e discutir o fato de um dos meus focos estar naqueles que saíram das ruas de S. Paulo, pois, o caso tratado na reunião tinha como personagem central um ex-morador de rua. Assumir diante daquele publico a minha posição foi uma atitude valorizada pela dona da casa, que me confidenciou posteriormente que uma das presentes havia lhe perguntado se eu seria de confiança. Afinal, como foi dito e será analisado em capítulo posterior, o caso tratado na reunião envolve diretamente uma separação no interior do assentamento entre aquelas famílias e o grupo de Walter.

Todas as questões metodológicas discutidas na Introdução emergem neste momento. Se para alguns assentados, fui associado ao grupo de Walter; para outros, dei mostra de confiança para além de minha pesquisa ser focada naqueles provenientes da rua. Pude concluir que, ao ser associado ao grupo de Walter, meu trabalho havia transferido algum prestígio para este ex-morador de rua. Potencialmente, virei um nó na rede dele. No 
entanto, aquela oportunidade de colaborar naquela reunião no dia de finados de 2004 foi um reconhecimento de que posso ampliar a rede daqueles assentados. E, sem pretender ser um mediador ou negociador do conflito interno, pude apresentar aos presentes naquela reunião que estava se consolidando uma polarização entre os grupos ali dentro e que, no entanto, a disponibilidade deles de fazer e desfazer aliança já havia sido maior. Porém, aquelas pessoas reunidas não tinham interesse direto na minha pesquisa, não haviam me chamado para ouvir minhas análises sobre os conflitos sociais internos. Somente lhes interessava era fazer um uso de meus possíveis contatos. Ou seja, fui visto como um nó na rede deles. Talvez tenha ganhado a confiança de alguns e perdido de outros. Como não houve necessidade de as mulheres irem ao INCRA, eu não fui acionado.

O caso citado mostra que o rumo atual do assentamento é de consolidar uma cisão. De um lado estão as famílias ligadas a Carlos, Frederico e Rosa e de outro aquelas associadas a Walter. Há dez famílias que, por enquanto, não pertencem a nenhum grupo. O primeiro grupo passou a excluir qualquer possibilidade de trabalho com as pessoas ligadas a Walter e este exclui de sua luta todos aqueles que não compartilham de suas "verdades". Pouco a pesquisa e o pesquisador contribuem nesse processo de fechamento da fração de território, a não ser servir para ampliar redes. A formação desses grupos, as trajetórias e as redes são tratadas no próximo capítulo. 
Foto aérea com a divisão dos lotes FIGURA 4

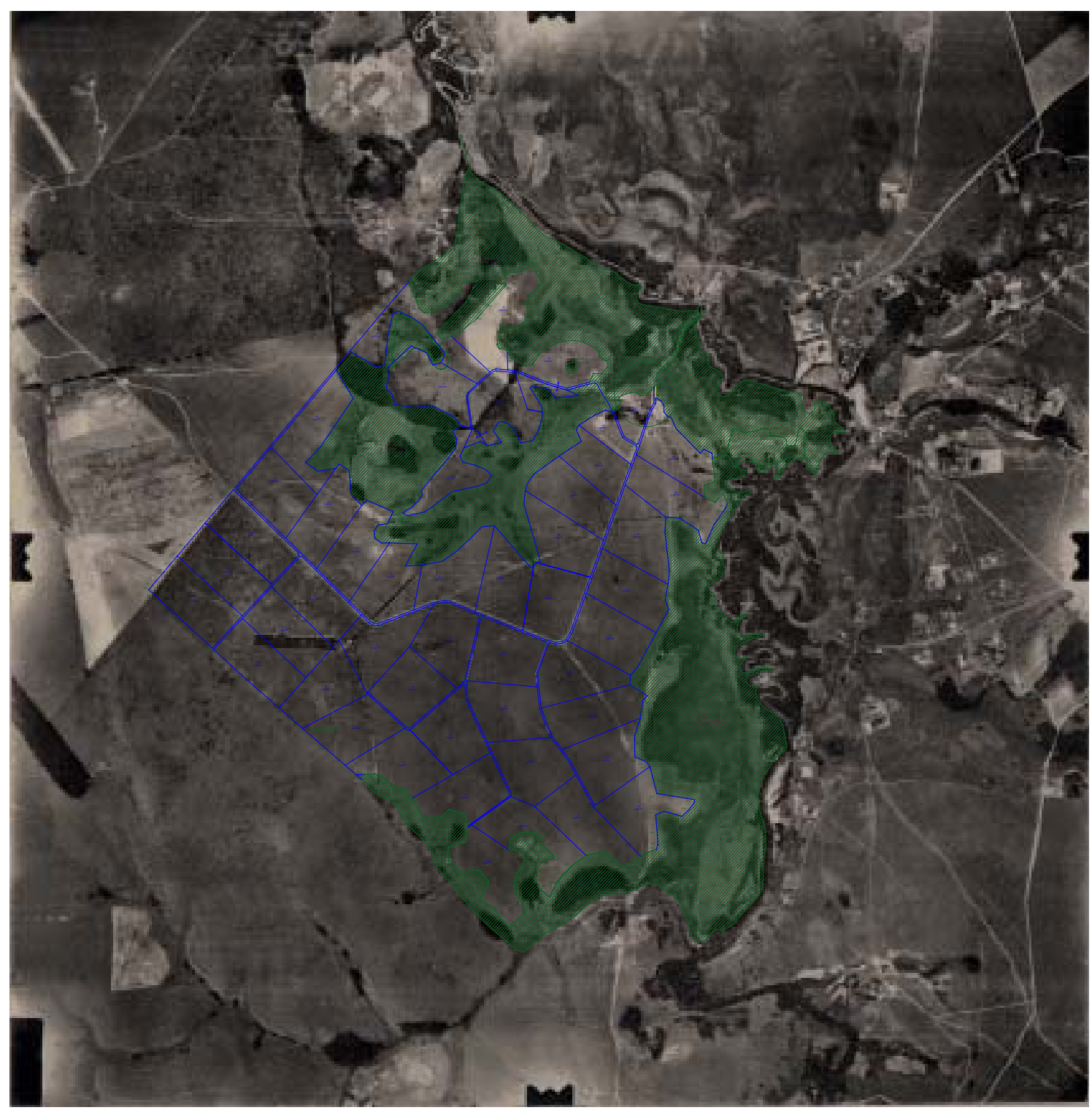

\section{Legenda}

Área agrícola (47 Lotes)

Reserva ambiental

- Rio 
Desenho de sítio padrão

FIGURA 5

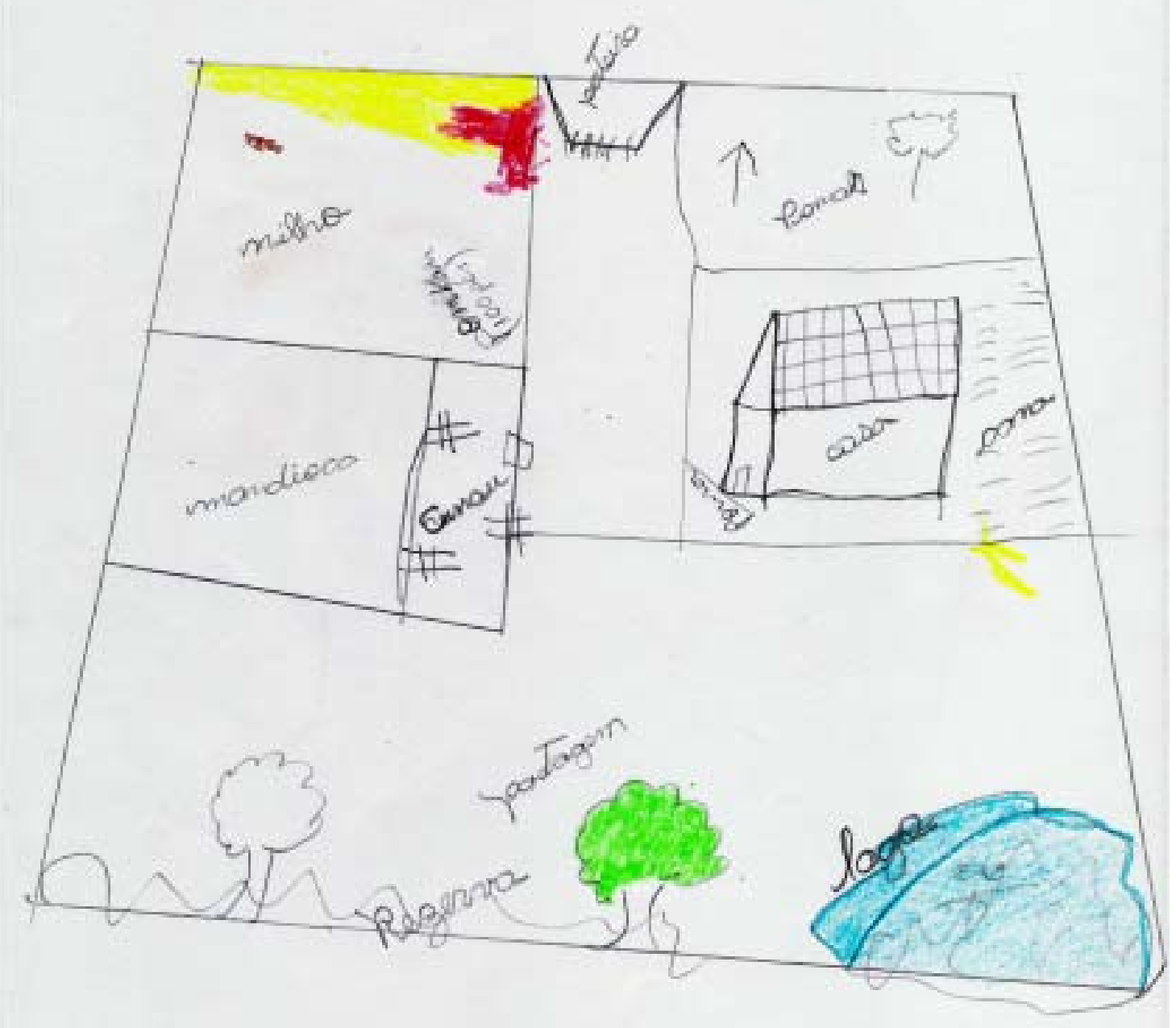


Desenho de sítio com pasto rotacionário

FIGURA 6

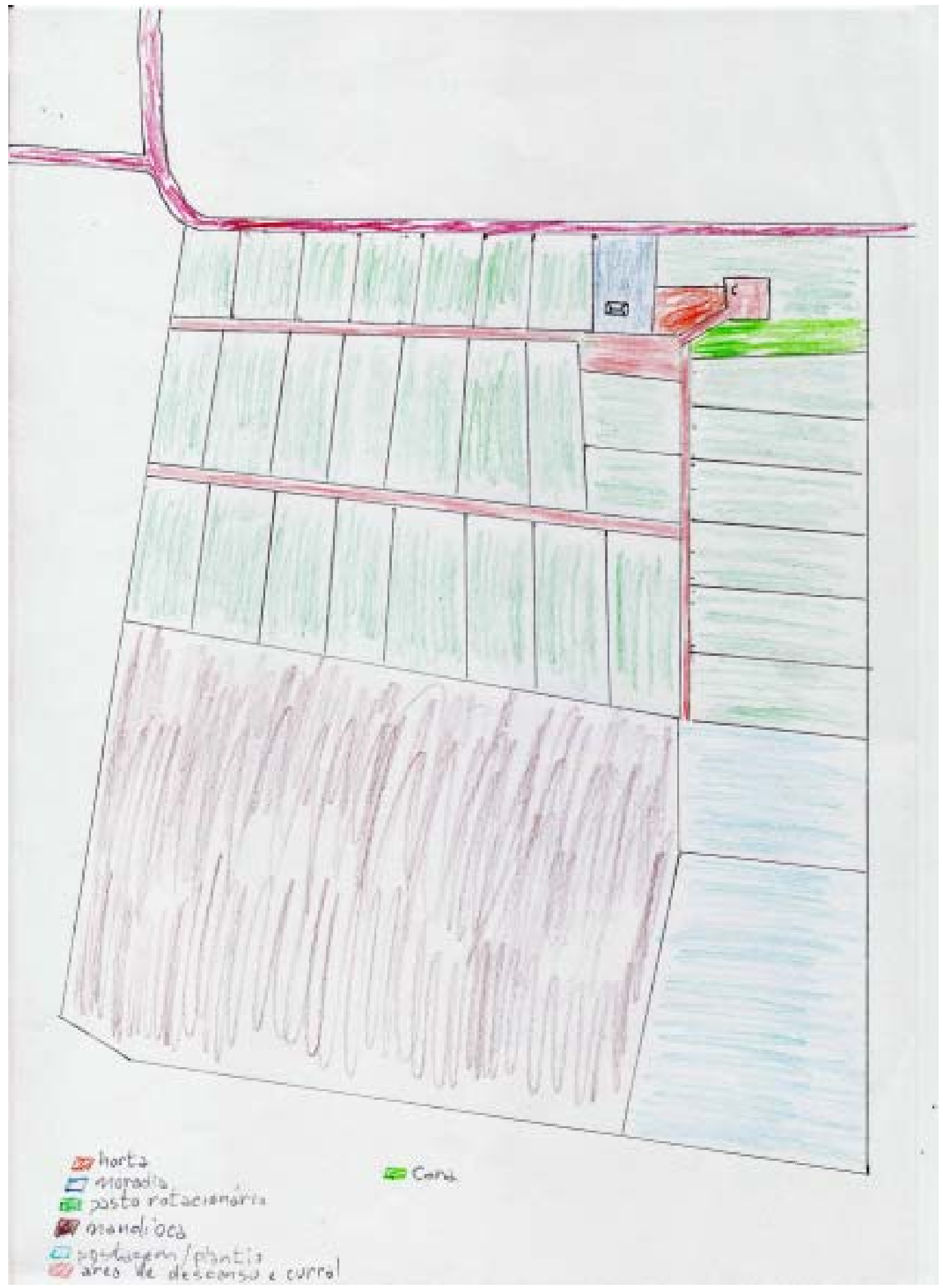


Desenho de sítio com estufa

FIGURA 7

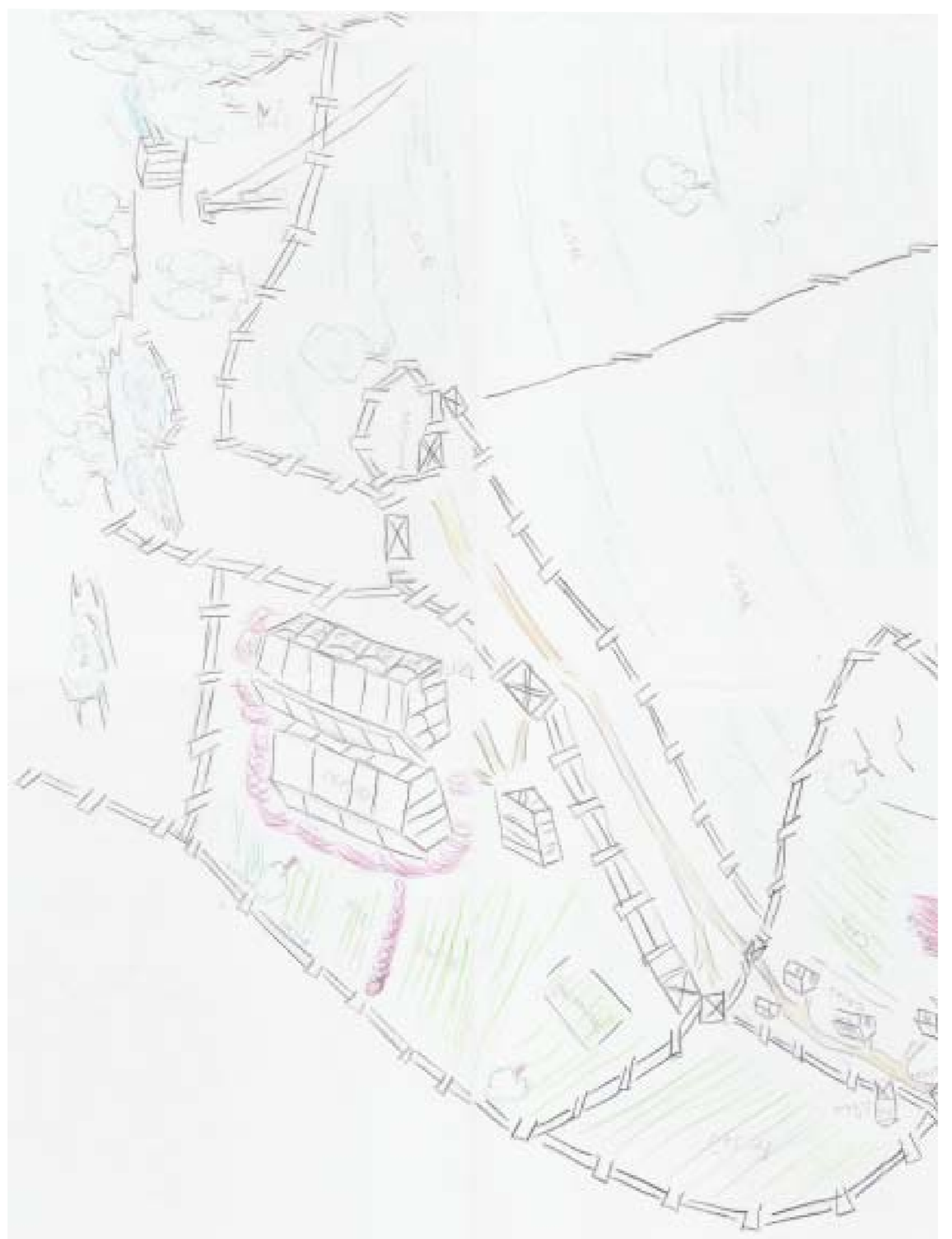




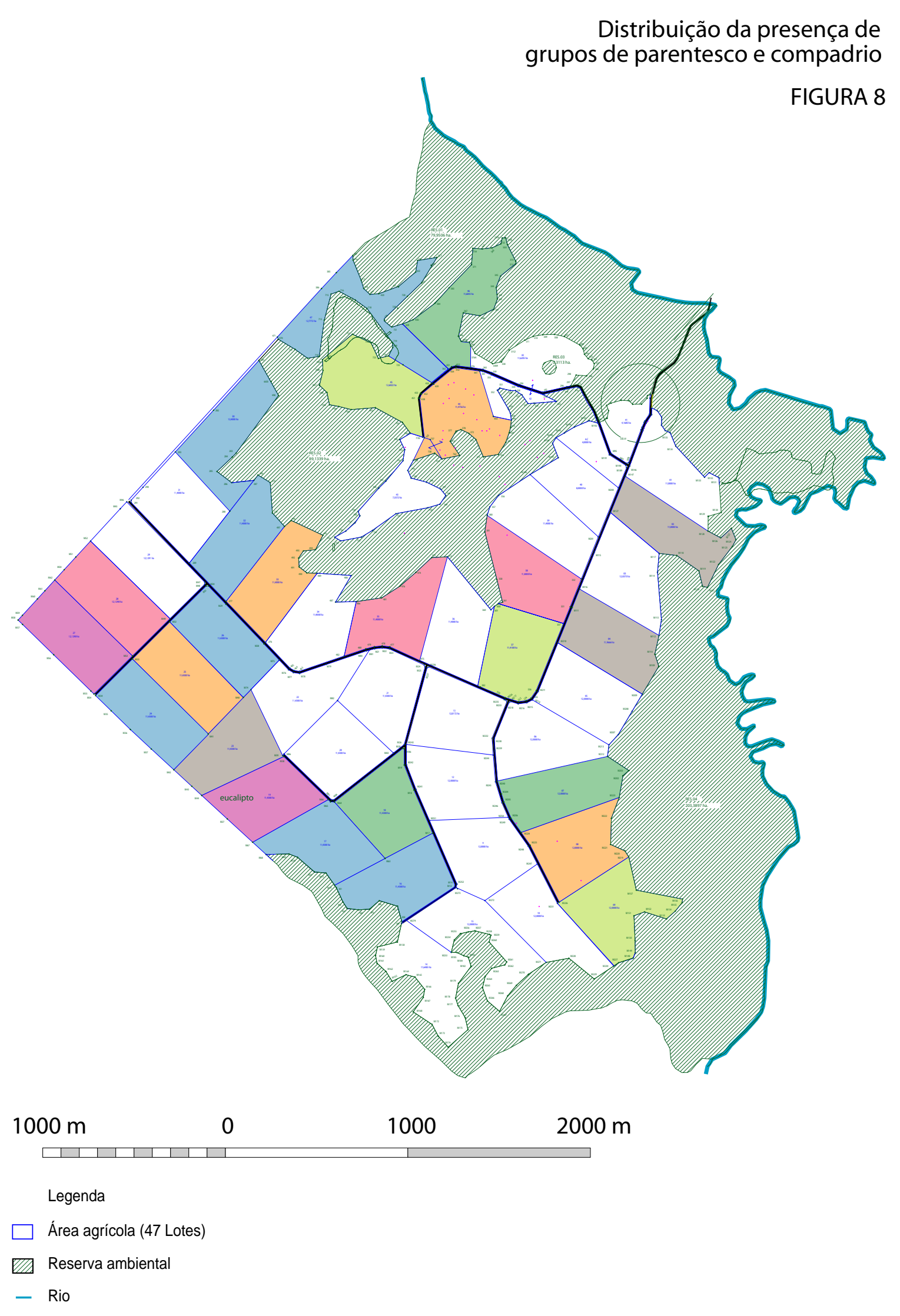

Famílias extensas, por grupo de parentesco

$\square$

$\square$ 


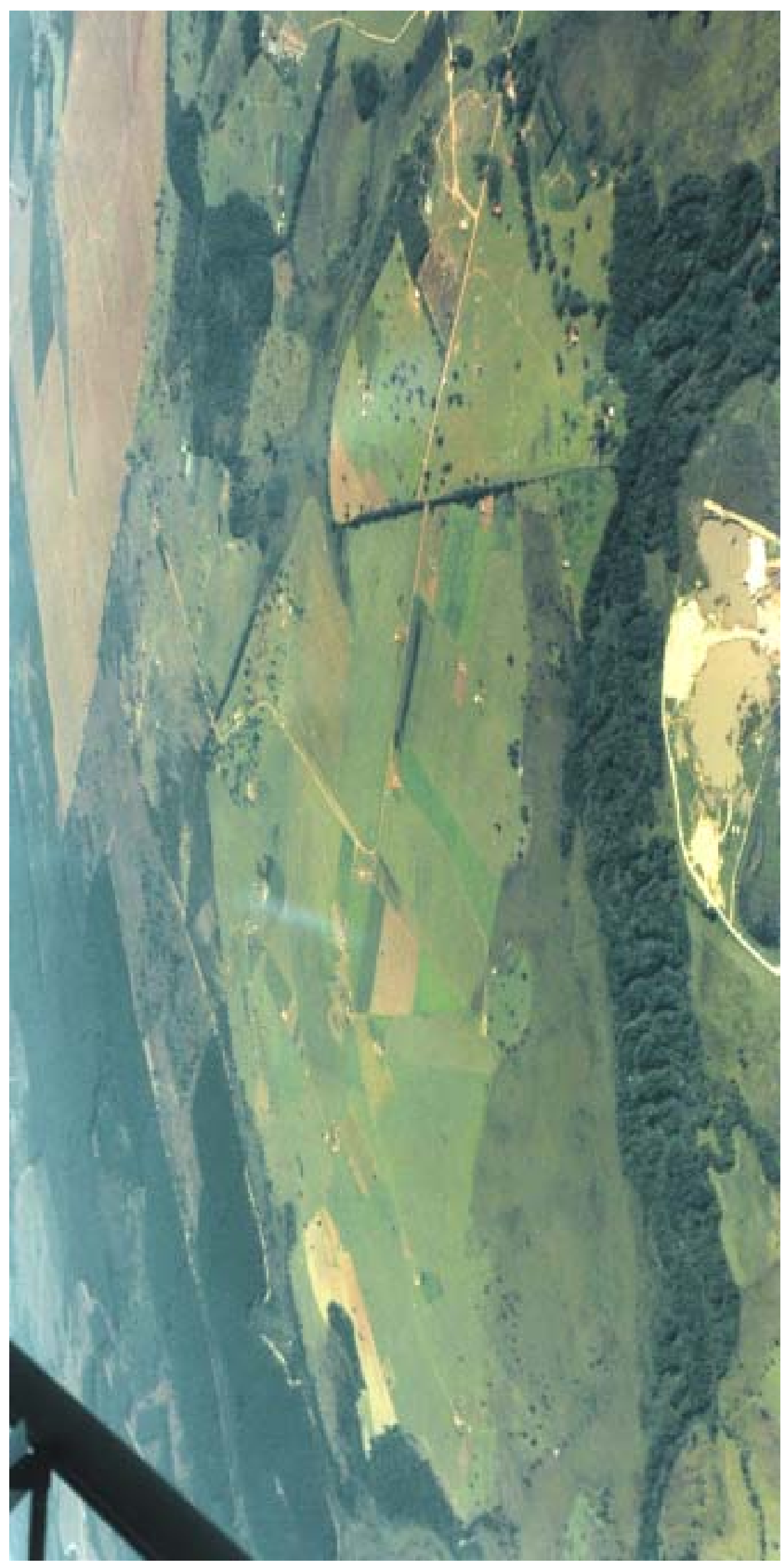

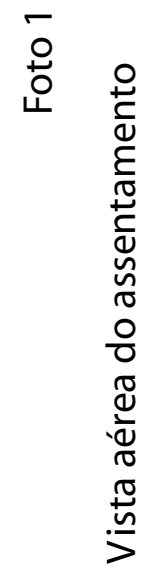




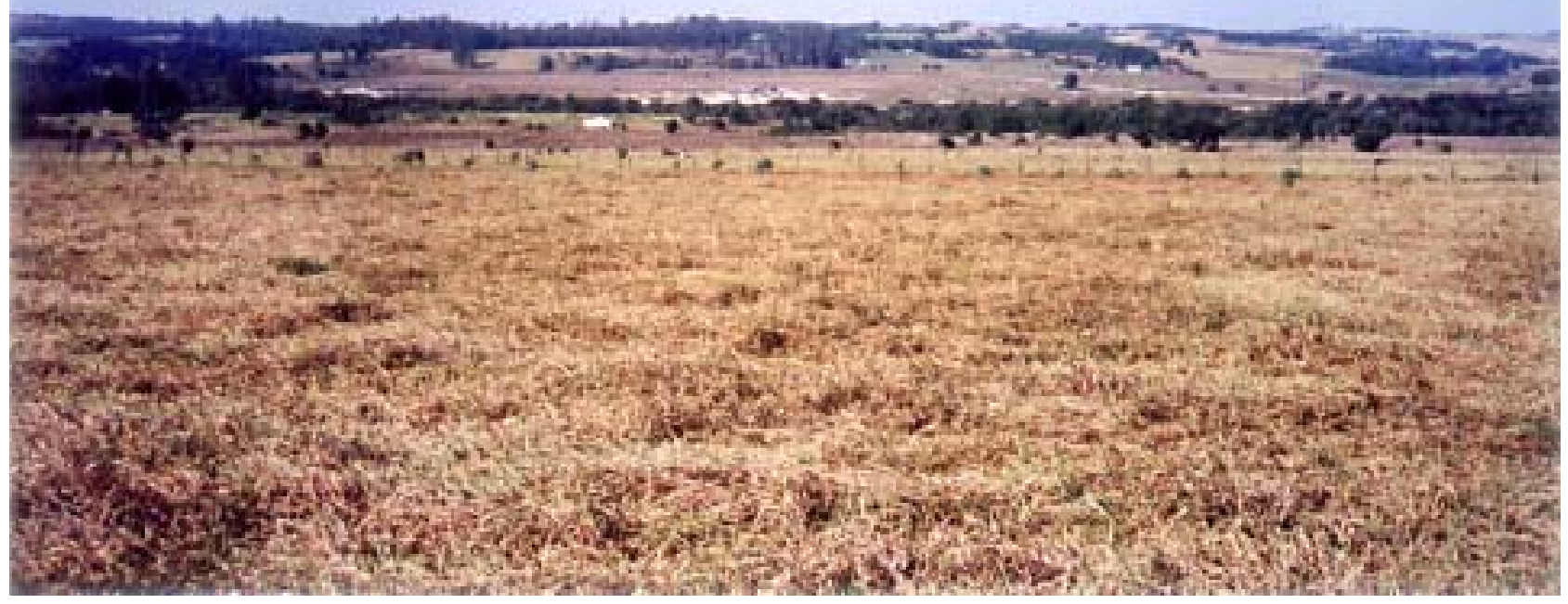

Foto 2

Vista parcial de um lote

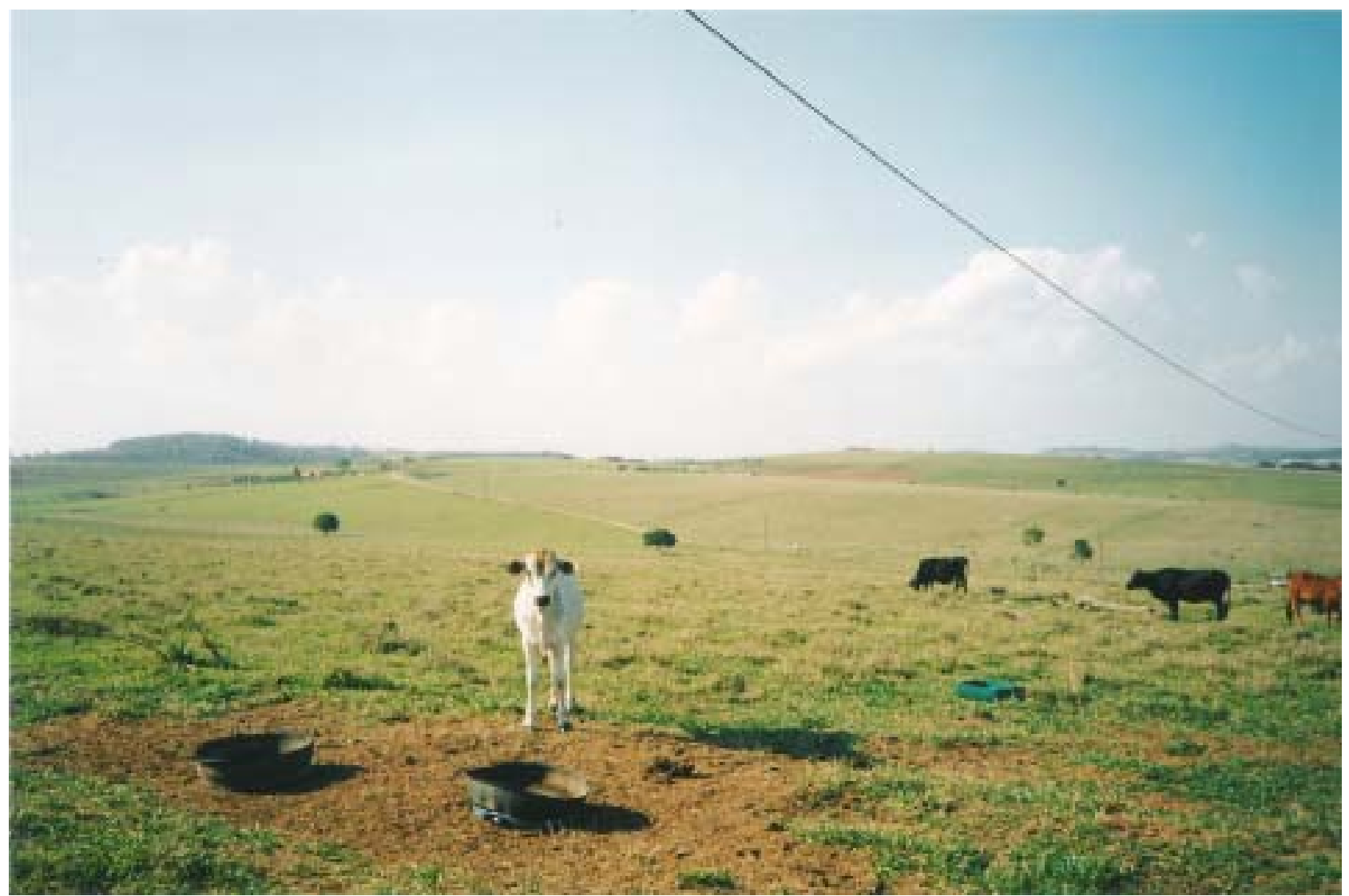

Foto 3 


\section{Conflitos, trajetórias e redes}

Eu acho que quando eu nasci, eu não sei, eu acho que Deus ponhô eu no mundo e disse: vai, só que tu vai ser um tranqueirinha, um encrenqueirinho, que vai querer as coisas pacificamente, honesto, e tu vai sofrer muito.

Walter $(5 / 05 / 01)$

A descrição do trabalho de campo continua neste capítulo. São apresentados conflitos sociais e redes de relações tecidas entre a maior parcela dos moradores do assentamento. Juntamente com as redes, a trajetória dos ex-moradores de rua assentados é destacada, uma vez que estes personagens são centrais no tema do trabalho. Algumas trajetórias de outros moradores também são expostas como contraponto à situação descrita. Após ampla descrição, procuram-se algumas interpretações e diálogos com demais autores.

O retrato é limitado pelo recorte temporal do trabalho de campo. Enfoca-se o período de tentativa e de formação de duas associações de moradores e de um grupo que une três semi-coletivos ${ }^{1}$. Uma das associações é composta majoritariamente por exmoradores de rua.

No caso de um assentamento recente, dificilmente as relações sociais se apresentam prontas, definidas de forma estanque, sempre sofrem transformações, ao começar a cristalizar se dissolvem; logo, as redes não são fixas, elas podem ser re-arranjadas. Porém, como foi visto no final do capítulo anterior, há também uma tendência a consolidar uma divisão entre grupos. Como ensinou Raffestin (1993), sobre o território (espaço político por excelência) são tecidas redes e estas possibilitam que aquele não se isole. Portanto, o enfoque nas redes permite apreender o movimento constante de ligar e desligar pontos, ou nós. As redes são traçadas através de controvérsias, ataques, alianças e associações. Precisa-se apreender quais são as nodosidades com densidades mais fortes ou mais fracas. Baseado em Serres, Raffestin coloca que as redes são instrumentos de poder por excelência porque tanto libertam quanto aprisionam o território. Vale lembrar que o autor se baseia na concepção foucaultiana de poder e o define, quanto aos meios mobilizados, pela combinação das variáveis independentes: energia e informação. "A partir de uma representação, os atores vão proceder à repartição da superfície, à implantação de nós e à

\footnotetext{
${ }^{1}$ Alguns moradores usam o termo semi-coletivo, mostrando familiaridade com as definições do MST. Sobre a distinção entre as formas de cooperação nos assentamentos, ver MST (1994).
} 
construção de redes" (RAFFESTIN, 1993: 150). Assim, os atores sociais diferenciam o espaço através de comportamentos que produzem território, surgindo tessitura, nó e rede, ou, superfícies (delimitação do espaço), pontos e linhas. No caso do assentamento, os nós podem ser lotes, instituições estatais, o MST, organizações civis etc. Lembrando-se que em cada nó pode ligar-se outra rede.

Para efeitos descritivos e analíticos, a concepção de rede é usada nesta tese no sentido de instrumento do poder - como definido anteriormente -, como algo que ocorre tanto interna quanto externamente à fração de território estudada e, portanto, possibilita acesso a outras redes maiores e está sujeita a constantes rearranjos. Neste sentido, opõe-se a cristalização presente numa “organização" de qualquer tipo, mas pode propiciar acesso a organizações $^{2}$. No assentamento, ter rede significa ter acesso aos vizinhos, aos serviços estatais e à sociedade como um todo. Como será visto, ter acesso aos serviços estatais (ao Poder), por exemplo, implica um grande gasto de energia e informação, ou poderes.

\section{As controvérsias recriando redes}

A principal controvérsia no assentamento ocorreu no final de 1998 e deixou seqüelas até 2004. Como visto na Introdução, inicialmente eram 63 famílias acampadas na fazenda, porém, segundo avaliação técnica do INCRA a área comportaria assentar 41. Foi colocada em assembléia dos pré-assentados uma proposta de que o dinheiro do financiamento de fomento, que seria concedido para as 41 famílias, poderia ser repartido entre as 63 e, quando as 22 famílias beneficiadas pela partilha fossem assentadas em outro local, pagariam de volta a quantia emprestada; seria um adiantamento. Segundo registro em ata, os presentes em assembléia ratificaram a proposta e assinaram um termo de responsabilidade.

Ao longo do trabalho de campo nenhuma das partes, assentados ou governo, assumiu diretamente a autoria da proposta de dividir o dinheiro de fomento. Porém, quase todos defenderam que foi o mais sensato, pois se todos lutaram juntos era natural que recebessem o dinheiro. Um dos principais coordenadores da época foi a favor de que as 63 famílias fossem assentadas no Clarice Lispector e, assim, procurava manter uma união do grupo e contava com o apoio da maioria. Outro coordenador queria manter todos

\footnotetext{
${ }^{2}$ As referências para o uso de "redes" são os trabalhos de Raffestin (1993), Haesbaert da Costa (1995a e b), Souza (1995) e Latour (2000a e b), com a ressalva do registro epistemológico completamente distinto entre
} 
assentados no local, mas não gostava da idéia de assentar pessoas sozinhas devido a pouca capacidade de trabalhar. E, um terceiro, simplesmente, era contra assentar as 63 famílias porque os lotes seriam menores, então, por ele os homens sozinhos deveriam ser excluídos. O desfecho já foi contado.

No entanto, em 2002, um dos moradores resolveu pressionar quatro excoordenadores do acampamento e da fase de pré-assentamento para reaver sua parcela daquela quantia da divisão do fomento, que segundo ele já poderia ter sido recebida ${ }^{3}$. Os quatro são acusados, por alguns, de negarem prestar contas daquele montante de dinheiro dos assentados, que havia sido dividido entre os companheiros do acampamento que não puderam ser assentados ali. Entre 2002 e 2003, um outro morador procurou um advogado acusando os quatro de terem recebido o dinheiro e não repassar aos demais moradores. Esses conflitos aparecem na formação dos "Exculhidos". Então, vamos ver como Walter retratou esse conflito, antes da formação de seu grupo.

Segundo contou, havia um laudo técnico do INCRA que estabelecia a capacidade da área desapropriada para o assentamento de 41 famílias. No entanto, todos eles que estavam acampados decidiram em reuniões e assembléia que deveriam ser todos assentados ali. O funcionário do órgão governamental, responsável por aquele processo, disse - numa reunião - que seriam assentadas aquelas famílias, as outras 22 ficariam numa lista de espera, e o governo federal já liberaria o financiamento de fomento, de 1425 reais para cada uma daquelas 41 famílias. Vale seguir as palavras de Walter:

É o INCRA, Nossa Senhora da Aparecida, não acredito! O 'cara' jogou tudo isso e jogou dinheiro na frente: - 'Ô gente, é para vocês, vocês é que resolvem'. Aí nós batemos em cima: - 'São 63 e não tem conversa'. E, na mesma hora, no meio daquelas 41 famílias: 'Ah, mas nós temos que receber o dinheiro. Estamos precisando desse dinheiro para fazer isso e aquilo'. Aí foi, foi e ele conseguiu destruir o que ele estava querendo. Não destruiu naquela hora, mas deixou a gente decidir. Batemos em cima, batemos em cima e ficamos um grupo com 22 famílias a favor do assentamento das 63 famílias. Teve 'nego' que ameaçou até de morte. (...) Foi, foi e eles [pessoas das 41 famílias] voltaram de novo. Com as mesmas idéias, e aí o pau comeu (...). Porque só resolvia se todo mundo... Se tivesse um ali contra não resolvia. A vantagem foi essa. Aí vai para lá, vai para cá os do sistema capitalista sentam-se e começam a discutir por causa do dinheiro. Dissemos para eles que

os autores. Para uma discussão do conceito de rede em geografia, ver Castro (1995), além dos autores mencionados.

${ }^{3}$ Houve desdobramento na Justiça civil decorrente da partilha do dinheiro de fomento. Isto será tratado no próximo capítulo. 
aquele negócio de dinheiro era espertada do governo. A estratégia do governo era aquela, era para destruir. 'Gente, nós lutamos todo esse tempo juntos e agora vamos deixar nossos companheiros jogados por causa de 1425 reais? Por dinheiro nenhum, gente. Vamos ter capacidade, vamos ter caráter, brio' [Walter teria dito numa assembléia]. Eu mesmo fiquei manchado. Chamei 'nego' para a verdade, gritei em assembléia, mas eles nem estavam aí. (...)

O órgão do governo conseguiu destruir. Foi o maior sistema capitalista, que é o maldito do dinheiro. Depois desses mil reais veio esse Pronaf ${ }^{4}$ sujo e imundo que foi pior ainda. Foi destruindo o pessoal e hoje esse pessoal está aí destruído. O pessoal só pensa em destruir, ele não pensa em construir um mundo melhor, um Brasil melhor. Se você for discutir política agrária com esse pessoal eles só se preocupam com a quantidade de dinheiro que vai sair. Se você for fazer uma entrevista com esse pessoal... as idéias deles são todas furadas. Por quê? Porque infelizmente o governo tem estratégia suja e imunda para jogar. É por isso que o MST tem que ter muito cuidado nessa sujeira do governo e ter estratégias para arrebentar com esse safado, sem vergonha. Porque ele usa poucas famílias dentro do assentamento... Famílias que não têm consciência política, ele usa para destruir os outros. Quer dizer, dentro do assentamento tem famílias que só pensam no lado delas. Só pensam em fazer para elas e para os filhos. Quando o maldito do governo vem com o sistema dele, oferece aquele sistema sujo e imundo aí elas saem falando para as outras: - 'Ó, nós temos tanto. E nós todos vamos ter que perder por causa desse povo'. Aquilo ali é um enxugamento, uma lavagem cerebral que o governo faz na idéia do palhaço que não tem diretriz com luta, não tem com nada. É uma pessoa destruída. Uma pessoa que se manipula por qualquer porcaria. Às vezes vende até a mãe dela por dinheiro. Porque a pessoa que tem capacidade não faz isso. Ela tem consciência porque além de pensar nos filhos dela amanhã, vai ter que pensar na sociedade. Na destruição que ela faz para a sociedade. Então a pessoa que tem essa consciência não entra nessa. Mas infelizmente, não é só aqui, isso acontece em vários assentamentos do MST.

\section{Os “Exculhidos": unidos por quatro meses}

Se em abril de 2001, Walter colocava-se com fazendo parte de um coletivo, um grupo de famílias com a de Rosa encabeçando, em 2002 ele passou a atacar aquele grupo e se uniu a outras pessoas do assentamento. Como tratado no capítulo anterior, em 2001,

\footnotetext{
${ }^{4}$ O Pronaf (Programa Nacional de Agricultura Familiar) foi criado pelo decreto lei No. 1.946, de 28/6/1996, do pelo governo federal. Tem como finalidade "promover o desenvolvimento sustentável do segmento rural constituído pelos agricultores familiares, de modo a propiciar-lhes o aumento da capacidade produtiva, a geração de emprego e a melhoria da renda"; ver: www.pronaf.gov.br.
} 
havia, na interpretação de Walter, dois coletivos, um em que ele participou e o outro que era o de Carlos e seus familiares e a família de Vladimir.

Em junho de 2002, Xavier contou que procurou Walter para formarem um grupo, uma vez que este não estava mais com a turma de Rosa. O primeiro disse que o critério para escolher as pessoas era não beber nem brigar. A partir desse momento, Walter passou a atacar seus antigos aliados, porque não seriam "verdadeiros" lutadores da causa do socialismo como ele. Quando Walter rompeu com os primeiros aliados, colocou-se como o legítimo representante do MST, como líder do anti-comportamento burguês e, quem não estivesse de acordo com seu modelo era burguês traidor da luta pelo socialismo "verdadeiro". Ele articula e reúne pessoas que foram atacadas por serem sozinhas. Então, ataca aqueles que eram contra o assentamento de homens sozinhos.

Então, no ano de 2002, começaram as primeiras reuniões na casa do casal Walter e Ema para a formação de uma associação de moradores no assentamento. Eram seis domicílios, sendo quatro deles com ex-moradores de rua: Ivan, Jonas, Abelardo e Walter. Quanto aos outros dois, há Xavier e a esposa, cujos filhos adultos não vivem com eles, e, num outro lote, uma família, composta pela mãe e um casal de filhos adultos (por volta de 2003, o filho se casou com a filha de Ednardo e se mudaram para outro lote, que se encontrava vago; eles aguardam a homologação do INCRA).

Numa reunião do grupo na casa de Walter, em 11/07/02, ele defendeu que a associação deveria ter em seu estatuto um item sobre a relação deles com os demais grupos do assentamento, porque a entidade não deveria ficar isolada. Outra questão colocada foi a dos projetos de produção coletiva: plantar maracujá e uva em dois lotes distintos e, em outros dois, construir tanques para piscicultura. Estes projetos teriam que ter registro no Itesp (Instituto de Terras do Estado de São Paulo, órgão da Secretaria Estadual de Justiça). Além da produção coletiva nos lotes dos membros da associação, ficaria assegurada uma parte para a roça do morador, "a horta no quintal tem que ter", como disse um dos presentes. O segundo ponto em pauta foi a entrada de novos membros na futura associação.Walter disse que Robério (também um ex-morador de rua) havia manifestado interesse em entrar na associação e que lhe ajudara na elaboração dos projetos de cultivo de uva e maracujá. Também defendeu a entrada de um homem mais velho, um ex-morador de rua que vivia sozinho e estaria "quase morrendo de fome". Menos de dois meses depois daquela reunião, esse ex-morador de rua abandonou o assentamento, sem dinheiro e sem ter como plantar. Jogou para o coletivo decidir, mas disse: - "eu não escolho ninguém, porque Deus não escolhe ninguém, Deus puxa". Um dos presentes foi contrário à entrada 
daquele ex-morador de rua porque não seria produtivo. Então não se falou mais no nome dele. Todos aceitaram que Robério viesse à próxima reunião.

Em outubro de 2002, a tentativa de associação perdeu o ritmo. Walter disse que somente ele e Abelardo estavam, de fato, tocando o trabalho e reclamou de haver pessoas pouco trabalhadoras. A presença de Robério teria contribuído para o fim do grupo, porque quis ser o presidente da associação e, no entanto, teria dito aos técnicos do INCRA que o grupo havia vendido uma cabeça de gado que ainda não lhe pertencia legalmente ${ }^{5}$. Abelardo disse que o coletivo desbaratinou porque havia muita fofoca e pouco trabalho. Disse que só duas pessoas trabalhavam e ficavam acusando um terceiro por não trabalhar, não cumprir os compromissos do projeto deles. Segundo Walter, um dos piores problemas no assentamento seria que as pessoas acabam se contaminando pela vontade de ser burguês, ele coloca toda a culpa nisso e centra fogo contra o "individualismo"6.

Pelo observado in loco na reunião do grupo, Walter dá o tom da discussão. Ele e sua esposa são os únicos que colocam em discussão a luta pelo socialismo. Para os demais, não é discutir o socialismo a prioridade. Segundo Walter contou, ele estava trabalhando sozinho em seu lote, havia largado a produção em conjunto com o grupo de Rosa, quando Xavier o procurou para lhe propor algo coletivo. A capacidade de articulação política de Walter parece ter importado. Essa capacidade faz-se notar na entrevista a seguir, realizada em 5/05/2001, um ano antes de o "Exculhido" ter sido formado.

Perguntado sobre qual é a luta do MST e o que reivindica, respondeu o seguinte:

Quando eu falo luta é que todos os brasileiros têm direito a reivindicar seus direitos. A luta significa o quê? A casa, o teto para você morar, a terra para você plantar, produzir, viver a sua vida as suas custas sem depender de ninguém. Você lutar pela sua educação, corretamente, lutar pela saúde, dignamente, lutar pela liberdade socialista séria, que é o respeito que nós temos para todos (...).

Nós não estamos querendo tumulto, não estamos querendo poder de ninguém. Estamos querendo, sim, a verdade, uma democracia séria. Porque nós estamos lutando contra todo esse papel e também contra a discriminação.(...)

Discriminação de cores e idades. Saber respeitar. Se jovens até os cem anos de idade; a cor, não interessa, pode ser preto, pode ser branco. Somos todos iguais. Isso é importante. O

\footnotetext{
${ }^{5}$ Walter falou, no final de 2002, que eu não deveria entrevistar Robério porque ele não me receberia bem. Deu a entender que mencionou com Robério algo sobre a minha pesquisa e o mesmo se irritou porque num outro trabalho de pesquisa ele haveria se sentido usado. Fui entrevistá-lo formalmente em 2004, após outros contatos.

${ }^{6}$ Foi curioso que nesse encontro (10/2002) com Walter, ele não contou que o "coletivo" havia acabado; somente quando Abelardo chegou e falou isto foi que ele assumiu. O que revela um desconforto diante do pesquisador.
} 
Movimento Sem Terra tem esse brilho, tem esse caráter de liberdade. Então, é por isso que eu vim para o Movimento Sem Terra, com um destino... Para uma coisa que vinha depois, que me destinou a voltar aquele nosso processo de antigamente, lutar junto, me entregar com aliança junto, que era aquilo que eu sempre quis: 'vencer, vencer'. Lutar para vencer. Para ver os nossos filhos, nossos netos, nossos companheiros dando risada. Abrir um lar, ter aquele lar viçoso com barriga cheia, com saúde e com educação. É muito importante você chegar numa praça e ver os velhinhos se divertindo, alegres e satisfeitos. Hoje você não vê nada disso. Você só vê tristeza. Então nós temos que passar por cima disso tudo e vencer para dar essa alegria, tanto aos idosos quanto aos jovens. Trazer harmonia, porque harmonia não é só levar ele para a mentira. Harmonia é dar a ele o que ele necessita: que é belos estudos, a educação, a saúde, o lazer, todo mundo ser respeitado. Eu acho que isso é uma coisa que nós devemos um para o outro. (...)

Não é só a terra. Então a política agrária envolve todo sistema, todo esse sistema que eu acabei de falar. Todo mundo tem direito ao lazer, todo mundo tem direito aos seus belos estudos, todo mundo tem direito a uma boa educação, todo mundo tem direito a sua casa própria, todo mundo tem direito a seu carro. E, também todo mundo tem direitos iguais, tanto pretos como brancos, tanto idosos como jovens. O Movimento Sem Terra tirou a conclusão que ele veio para a luta, veio com o destino da reforma agrária, de fazer a reforma agrária.

Constata-se a disposição de Walter em trabalhar em conjunto. Porém, neste caso trabalho em conjunto leva a reconfigurações constantes de tessituras, nós e redes; é um movimento de conectar e de desconectar linhas entre lotes. Da fala anterior, pode-se interpretar a posterior posição dele: não aceitará mais se unir com aqueles que julga serem contrários a suas convicções políticas.

Para ter uma nova associação eles tiveram que romper com os antigos coordenadores do assentamento. Naquele momento (junho de 2002), Walter passou a atacar um dos ex-coordenadores, colocando neste toda a culpa pelas consequiências da divisão do dinheiro de fomento. Walter assumiu que não estava na assembléia em que se decidiu a divisão do fomento, pois estava fazendo trabalho de base. Mudou sua rede, mudou seu discurso.

Walter procurou agregar as pessoas através do grupo "Exculhidos", em 2002. Trouxe mais um para o grupo, no entanto, houve o esfacelamento. Com esse grupo, os "coletivos" de Rosa e de Carlos viraram alvo de críticas porque ficavam restritos aos familiares. Com a dissolução dos "Exculhidos", houve troca de acusações entre os membros e ex-aliados foram classificados de "preguiçosos" ou "vagabundos". Mesmo com 
quem ainda trabalha junto ou com aqueles que virá a se unir futuramente, Walter chama de "preguiçosos". Passou a dirigir ataques a Robério, porque teria provocado a dissolução do grupo. Disse que tem muita fofoca ali dentro e muitas pessoas "vendidas ao sistema capitalista", critica um de seus companheiros por "seguir a cabeça" de Ednardo e levar os problemas internos para a Justiça. Segundo ele, há duas pessoas que recorrem à Justiça para tratar dos problemas internos. Na figura 9, observa-se, por meior de flexas, as alianças e os ataques entre os moradores que, em diferentes momentos, estiveram envolvidos na formação dos "Exculhidos" e da Compartilha.

A seguir, as entrevistas ajudam a esclarecer a formação do grupo mencionado e mostram, em parte, porque o trabalho coletivo não vingou, pois, numa parte delas ressoa a dissonância da associação. Elas apresentam os personagens enfocados neste texto, as suas trajetórias e as suas redes de relações sociais.

Ivan $^{7}$ tem um filho, mas entrou sozinho para a luta. Em 2001 conseguiu uma companheira, que é irmã de sua vizinha de lote. Ele nasceu em 22/09/1960, em Porto Calvo/AL. Sua trajetória da rua ao MST foi contada brevemente. Saiu de Alagoas em 01/01/1996 e foi direto para Cubatão, trabalhar numa firma. Passaram dois meses e a firma o levou para Campinas, onde permaneceu por cinco meses. Depois partiu para S. Paulo.

Ficou cerca de dois meses em São Paulo a procura de emprego. Fazia "bicos" [trabalhos temporários]. Ouviu um grupo de pessoas no Parque D. Pedro dizer que uns padres estavam organizando um pessoal para a luta pela terra e resolveu participar. Nunca tinha ouvido falar do MST. Como não conseguia emprego fixo, decidiu entrar para o Movimento.

Após a dissolução do grupo com Walter, Ivan ficou restrito à união com a esposa e na ligação dela com a irmã. Por fim, disse que no assentamento é "cada um por si e deus por todos; coletivo não dá certo". Contou também que trabalhou no primeiro "coletivo", mas não receberia a contento, então o largou. Disse que nos "Exculhidos" tinha muito discurso e pouca ação. Ficou reticente em trabalhar em coletivo. No entanto, com a articulação da Compartilha entrou para a organização, pois alguns laços ainda o ligavam a essa rede.

\footnotetext{
7 A entrevista com Ivan, realizada em 18/10/2002, não teve um caráter formal, pois não foi gravada e as perguntas foram fechadas. Ele não chegou a recusar a dar a entrevista, porém ele se mostrou pouco comunicativo, não desenvolvia seus pontos de vista e transpareceu que, de imediato, só exporia aquele pouco. Respeitei sua posição e, ao invés de insistir numa entrevista formal (gravada), anotei suas falas no caderno de campo.
} 
Ivan desistiu de viver no assentamento, em 2004. Brigou com a esposa e foi embora para Alagoas. Seu vínculo com a terra não resistiu suficientemente para continuar a luta pela produção no lote. Mais do que isso, sua situação nas redes do assentamento abriu furos. Foi acusado de receber dinheiro de uma vizinha pelo lote. Este caso será analisado no próximo capítulo. Por enquanto, vale dizer que o lote de Ivan ao longo dos anos de pesquisa mostrou poucos avanços em comparação a outros em melhores condições. Afinal, ele era sozinho a arar, sua mulher pouco o ajudava. Assim, outros moradores o viam como potencial vendedor de lote.

Outra pessoa que participou da formação do grupo é Jonas ${ }^{8}$, que foi sozinho para a luta. Por volta de 2002, ele conseguiu uma companheira com dois filhos pequenos para morar junto; porém, a relação não perdura, tem idas e vindas. Ele nasceu em 20/10/1947, em Peçanha/MG e passou muitos anos em Governador Valadares. Sua trajetória de vida foi resumida da seguinte forma:

Tinha mulher e cinco filhos em Governador Valadares. A mulher foi embora, eles se desquitaram e ele ficou cuidando dos filhos por quatorze anos. O sogro tinha 2 mil alqueires de terra, onde ele e os filhos viviam e trabalhavam. Em São Paulo, viveu por três anos como "marreteiro" [vendedor ambulante]. Tinha uma banca no Parque D. Pedro, onde vendia "de tudo", tinha dois empregados em banca de doces. Um dia, os fiscais da Prefeitura levaram toda a mercadoria. Ele morava em um cômodo e foi roubado; decidiu, então, pagar um hotelzinho para não ser mais roubado.

Perguntado como entrou para o MST, disse brevemente que uma vez um padre da pastoral da rua lhe perguntou se não queria participar da luta pela terra e ele topou.

Da ocupação da fazenda até a demarcação dos lotes, trabalhou junto com o grupo de Carlos para, posteriormente, também romper. O grupo dos "Exculhidos" foi uma oportunidade para ele estar numa rede, porém não durou. Quando fui entrevistá-lo, comecei a conversa me referindo à reunião do coletivo na casa de Walter. Ele colocou que nas reuniões dos "Exculhidos" havia muita conversa e pouca ação e ele não viu resultados das reuniões como o registro do estatuto, por exemplo. Em comparação, o grupo de Carlos seria um exemplo de como um grupo pode ser bem sucedido, apesar das críticas. Jonas disse que trabalha muito e que gosta de trabalhar. Mas, reclama das péssimas condições de seu lote, a terra seria muito ruim para a agricultura e não adiantaria adubar. Lamenta estar naquele lote. Disse que a Igreja promete terra, mas se ele soubesse que seria naquelas

\footnotetext{
${ }^{8}$ Jonas respondeu, em 15/11/02, às minhas perguntas defronte a sua casa, nós dois em pé e a cerca entre nós. Ele se recusou a dar uma entrevista formal. Anotei rapidamente umas falas no caderno de campo.
} 
condições, não iria. No entanto, ele reconhece que é melhor estar ali do que na rua. Ele acha que se o padre prometeu ajuda, deveria dar coisa melhor. Atribui também a culpa ao INCRA.

O lote de Jonas fica numa parte do assentamento conhecida por tocos, onde havia eucaliptos que foram derrubados e ficaram as raízes secas espalhadas. A terra é visivelmente seca e estava sem roçado algum em 2002. Em 2004, o lote continua com a maior parte da área com tocos, pois não teve recursos para destoca. Porém, em torno da casa há um galinheiro, uma horta, um pomar e plantação de mandioca e cana. Ao lado tem um curral para as quatro cabeças que pastam na área de tocos e uma área cercada de aproximadamente 1 ha com cultivo de mandioca e milho.

Abelardo é outro que participou do grupo "Exculhidos" e, pelo menos até final de 2002, continuou a trabalhar junto com Walter. Após um tempo foi chamado para participar da Compartilha. Ele nasceu em 12/02/1958 num povoado pertencente ao município de Mato Verde/MG. Em entrevista realizada em 18/10/2002, ele mostrou sua trajetória pessoal até então. Vive sozinho no lote.

Disse que nunca freqüentou escola e trabalhava desde criança auxiliando a família. Viviam na terra "dos outros", nunca tiveram terra própria. Com o falecimento do pai, aos 14 anos saiu de casa e foi "para o mundo". Viveu no Mato Grosso, Mato Grosso do Sul, Rondônia. Voltava para Minas Gerais, mas para outras áreas além daquela onde nasceu. Não tinha onde morar, então pernoitava onde estava trabalhando. Trabalhava em fazendas, roçava pasto, dava água ao gado, fazia qualquer tipo de serviço: panha de algodão, quebra de milho, desde os 14 anos. Enfrenta qualquer tipo de trabalho: pintura de parede, reboque, trabalho com trator, caminhão.

Perguntado por que entrou para o MST, respondeu que fez muitas caminhadas procurando emprego e só encontrava o desemprego, desde o governo federal de Itamar Franco [1992-94]. Foi ao Paraná e a Santa Catarina, mas não conseguiu emprego fixo. Então, voltou para São Paulo. Encontrou mulheres do trecho, que vivem nas ruas, e elas lhe contaram que havia um padre que estava cadastrando as pessoas para lutarem pela terra. Ele se interessou e começou a freqüentar as casas onde os padres faziam as reuniões sobre a luta pela terra. Estava num serviço temporário e, por isso, largou para entrar na luta. Conheceu todo o Movimento, a história, os debates, estudou, viu que havia uma forma coerente de lutar pela terra. Ficaram seis meses se preparando, rezando, juntando fundos para comprar lona. Disse: - 'Estou hoje 'fracassado', o lote não tem nada, mas consegui um lugar para deitar minha cabeça, estava no desespero”. Vivia nos albergues, 
quando entrou para o Movimento. Foi “de rua, várias vezes”, porque quando era mandado embora de um emprego, ficava na rua. Disse que viveu assim por 30 anos, sem emprego fixo e sem moradia. Morando em albergues e na rua, passou 15 anos, mais ou menos. Era de rua porque não tinha terra e não tinha onde morar, se justifica. A falta de um lugar para morar, para ter uma família, o levou a entrar para o Movimento.

Como mencionou algumas vezes a palavra "justiça", perguntei-lhe o que é a justiça, ao que respondeu: - "No Brasil e pelo mundo, a justiça seria união, compreensão, negociação... e não para um furar o olho do outro. Ninguém quer a negociação. (...) A justiça tem que ser reta".

Pode se traçar a seguinte rede para Abelardo. Há uma linha que o liga a Walter. Censura um vizinho por não trabalhar. Dirige críticas a um suposto responsável pela divisão do fomento. Os ex-coordenadores do assentamento ficariam com "safadeza" por não convocarem uma assembléia para discutir o problema desse dinheiro, enfatiza. Segundo ele, todos teriam trabalhado na construção da primeira estufa, mas não teriam recebido.

Quanto ao coletivo dos "Exculhidos", disse que não dava para continuar a associação porque havia negação. Explicou que negação é: uns entram no coletivo e outros ficam de fora, por trás, e fazem um conchavo, no sentido de quando um lado enfraquecer eles entram e tomam conta de tudo. "Houve negação porque eles não queriam ceder a terra para poder plantar, sendo que essa terra seria melhor. Quando a gente discutia uma coisa em segredo, numa reunião, ela tinha que ser mantida em segredo". Não manter o segredo é negação. Uma pessoa usar somente em suas terras um trator que foi comprado com dinheiro de muitos, também o é, exemplifica novamente. Disse que um dos moradores é seu "inimigo" porque teria dito que homens sozinhos não deveriam ser assentados.

Algumas observações devem ser feitas. Durante a entrevista, Abelardo repetia críticas ao governo, ao Estado, no sentido da falta de condições básicas para a população: terra, escolas etc. Provavelmente me associou ao Estado. Procurava se justificar por ter sido morador de rua por falta de condições; teria sido obrigado a viver naquela condição por falta de políticas sociais, e se diferenciaria do mendigo, que é bêbado e não ajuda o país a progredir.

Atualmente ele tem quatro cabeças de gado; é no que dá para investir devido à má qualidade da terra, avalia. Tem um roçado de milho e cana para o gado. Em 2004, plantou mandioca numa área próxima a casa. Pomar e horta são quase inexistentes. 
Zé Bento ${ }^{9}$ vive sozinho no lote, não tem mulher nem filhos. Ele nasceu em 23/09/1954, em Goiânia/GO. Morou e trabalhou na cidade até a idade adulta quando se mudou para a cidade de São Paulo, onde foi carpinteiro. Contou que ouviu de trecheiros que no Mato Grosso havia trabalho. Foi para aquele estado, onde trabalhou por dois anos na roça e voltou para São Paulo. Conheceu o MST pelos padres em São Paulo que convidavam a turma para as reuniões sobre ocupações. Os padres corriam atrás das pessoas em condições de miséria nas ruas e periferias. Veio sozinho e vive só.

Quando foi para o lote, comprou gado conforme orientação do INCRA para aquele tipo de terra. Foi vendendo todas as cabeças. Considera que o gado lhe deu prejuízo. Passou a arrendar alguns alqueires para plantio de melancia. Em 2003, entrou para o grupo que deu origem a Compartilha. Porém, continuou com formas de arrendamento. Em 2004, fez uma sociedade com uma pessoa de fora do assentamento que possui equipamentos para plantar um alqueire de mandioca. O sócio planta, os dois são responsáveis pela limpeza e a venda é dividida meio a meio.

Disse que está satisfeito de estar assentado. O lote agora está em boas condições de moradia, fez uma cisterna que resolveu a falta d'água. Considera que a associação "não vira em nada, não tem trabalho em conjunto, não é como a de outro".

Outro nó na rede dos Exculhidos é Robério ${ }^{10}$, casado e com oito filhos. Ele nasceu em 1958, em São José do Rio Preto/SP e, depois, foi para Araraquara/SP onde ficou 18 anos. Em 1986 foi para Rondonópolis/MT e entrou para a militância do MST, participou de ocupações e teve a função de coordenador de saúde. Por críticas a direção se desligou do Movimento. Ele e a esposa viviam como "peões de boiadeiro", indo de fazenda em fazenda a procura de trabalho e sem ter moradia. Em torno de 1996, foram para São Paulo com os filhos, onde ficaram por um mês no Centro de Triagem (Cetren), no Brás. As crianças adoeceram devido às condições do local. Foram morar em Mairiporã, grande São Paulo, como caseiros por indicação de uma pessoa do local de triagem. Ficaram três meses e se mudaram para o estado do Tocantins. A família voltou para Andradina/SP, terra de sua esposa, e Robério foi para São Paulo procurar as reuniões dos padres na igreja "da Torre", no Brás, onde havia o grupo de formação do MST. Então, foi com a turma de egressos da

\footnotetext{
${ }^{9}$ Zé Bento foi quem não quis ser identificado como ex-morador de rua no início do meu trabalho de campo. Portanto, procurei-o após dois anos (em 20/12/04) sem mencionar o tema do MST como alternativa aos moradores de rua, apliquei-lhe perguntas sobre sua trajetória profissional e a situação no lote. Porém, em alguns termos de sua fala, como trecheiro e "turma que os padres reunia", é possível identificar a proximidade com as pessoas de rua.

${ }^{10}$ Ver nota 5. Entrevista realizada em 21/12/04.
} 
rua para o acampamento em Alencar/SP. Depois de acampado, foi buscar a esposa e os filhos que haviam ficado em Andradina.

Em 2000, o casal estava com quatro filhos e em 2004 têm 8, sendo que o mais velho está com 11 anos e o mais novo tem 2 meses. Atualmente, Robério trabalha sozinho no lote, com a ajuda da esposa. Em 2003, havia arrendado uma área para cultivo de melancia. Nesse mesmo ano, protocolou na superintendência regional do INCRA uma carta apontando irregularidades no assentamento e também enviou para um jornal local carta semelhante. Naquela época tentou vender as benfeitorias para um interessado de fora do assentamento e deixar o lote, porém, a maioria dos moradores pressionaram para que não houvesse a venda. Isso será tratado no próximo capítulo.

Em 2002, Walter o procurou para entrar para o grupo dos "Exculhidos", porém, como visto anteriormente, foi responsabilizado pelo desmantelo do grupo. No início de 2004, mais uma vez Walter o chamou para entrar no grupo e formaram a associação Compartilha. Mas, no final do ano de 2004, havia deixado a associação porque não havia recebido crédito para plantio de mandioca. Portanto, se convenceu de que no assentamento é cada um por si. Disse que está vivendo tranqüilo com o que planta no lote, é o suficiente para comer sem depender de ajuda externa. O dinheiro mensal que a família dispõe consiste em um arrendamento de pasto e em bolsa escolar do governo federal para as crianças. Pretende vender as benfeitorias e ir embora para a cidade após vencido os 10 anos de contrato com o INCRA.

\section{Do lado de fora dos "Exculhidos"}

Ademir $^{11}$ vive sozinho no lote e, em 2002, estava isolado no assentamento. Seu lote é no extremo sul do assentamento. Ele não se inseria em qualquer dos grupos até que Walter o chamou para entrar para a associação Compartilha. Nasceu em 23/02/1950, em Bom Despacho/MG.

Ele apresenta da seguinte forma sua trajetória pessoal. Estudou até o ensino médio, parou no último ano. Nasceu em Minas e, aos 23 anos, foi para S. Paulo a procura de emprego. Trabalhou como auxiliar de escritório em bancos, como "encartador" [montava os vários cadernos do jornal, que vinham separados da gráfica], como porteiro, faxineiro, vigilante, "fazia de tudo". Vivia em albergues e na rua. Acredita que morou por uns quatro anos nas ruas.

\footnotetext{
11 Ademir foi entrevistado em 22/11/02. Ele recusou que a entrevista fosse gravada; então, anotei suas respostas no caderno de campo.
} 
Quando apareceu o MST, ficou sabendo do que se tratava, se interessou e foi para o acampamento em 1996. Disse que o MST foi uma boa para ele, foi uma oportunidade que teve. Nunca trabalhou na roça, a não ser quando era criança que ajudava o pai, mas por pouco tempo, pois este logo largou o roçado para ser pedreiro.

Freqüentou a casa da coordenação da pastoral do povo de rua, até que um dia vieram umas pessoas falarem sobre a luta pela terra e o MST. "Eu sempre fui ligado politicamente e entendi o que era o MST. (...) Nós passamos a brigar pela aplicação da lei da reforma agrária que existe".

Está satisfeito por ter ido para o assentamento. "É só trabalhar que tenho o que preciso. Antes minha vida era uma incógnita. O MST foi a primeira oportunidade que me apareceu e eu topei".

Disse que o relacionamento com os vizinhos é fraco, é cada um por si e tem pessoas que são difíceis de conviver. Vê como problema no assentamento as condições de produção e o relacionamento. "É começar a produzir, depois [de começado] já muda a situação. (...) Aqui, trabalhar em grupo, de modo comunitário, não funciona. Começamos juntos e acabou, ficou só o Carlos. (...) Não funciona porque a força de trabalho é desigual, o conhecimento é desigual (...), não funciona; não funcionou até hoje. É difícil mudar”. Enfim, acha difícil trabalhar em grupo devido a como é ali: há muita desconfiança um do outro. Se fosse para melhorar, ele iria trabalhar coletivamente, mas isso não acontece.

No entanto, entrou para a Compartilha, em 2003-2004. Então, plantou 3 ha de mandioca. Segue sua vida sozinho no lote no limite com o isolamento.

Outro assentado que chegou a morar nas ruas de São Paulo é Ednardo ${ }^{12}$. Ele e a esposa vivem num lote e têm uma filha casada que vive noutro lote. Ele liderou uma oposição a Carlos, em 1999, e a favor da divisão dos lotes. Tem origem no campo, mas uma trajetória de militância em movimentos sociais urbanos. Seu pai era meeiro em MG, quando Ednardo tinha 3 anos perdeu a terra de trabalho e foram para a cidade. Depois de adulto, Ednardo se mudou para S. Paulo. Trabalhou numa igreja na zona norte da cidade, onde conheceu um padre que lhe falou da pastoral operária. Então, ele se politizou, leu autores marxistas e virou um militante de esquerda. Trabalhou por 28 anos num supermercado e perdeu o emprego. Após três meses foi despejado. Então, ele, mulher e a filha foram morar na rua. Ficaram por 32 dias nas ruas. A mulher e a filha se abrigavam atrás de uma igreja. Conta que foi procurar um padre que o indicasse como entrar para o

\footnotetext{
${ }^{12}$ Não houve uma entrevista formal e gravada com Ednardo, apenas ele contou sua trajetória enquanto eu registrava no caderno de campo, em 10/02/04.
} 
MST. Ele, mulher e filha foram para os acampamentos em Alencar/Irene na segunda turma organizada pela Fraternidade Povo da Rua. É muito agradecido ao MST, mas não faz parte do Movimento. Disse que não participou da primeira estufa da fase de pré-assentamento nem de outros projetos coletivos porque os considerava equivocados. Não se coloca como o "do contra", mas disse que tem de ser convencido porque sempre mostrou suas divergências políticas com os demais.

Vale mencionar que Ednardo foi um dos primeiros a abrir processo criminal no assentamento, devido a brigas pessoais. Por isso, as pessoas do assentamento dizem que quando alguém procura a polícia ou o Fórum por causa de algum conflito no assentamento está agindo "pela cabeça de Ednardo, ou a mando dele". Voltarei a este ponto.

\section{Após os “Exculhidos”, a Compartilha}

A união dos "Exculhidos" teria acabado porque Robério quis liderar e ser o presidente. Ele teria denunciado aos técnicos do Itesp que havia entre aquele grupo pessoas que arrendam o lote para gado pastar. O grupo durou de junho a outubro de 2002. Contava com 4 membros que eram da rua e outras duas famílias. Quando entrou Robério, acabou o grupo.

Em 2003, Walter articula um outro grupo chamado Compartilha, com 12 famílias. Uma dessas famílias sempre foi atacada por Walter e, mesmo assim, se uniram; afinal, Walter sempre fala em unir. Porém, meses depois, Walter diz que a associação não se consolidou por causa daquela família.

Em janeiro de 2004, eles registram em cartório a associação beneficente de trabalhadores rurais e urbanos Compartilha, com sede no sítio de Walter. É formada por 14 sócios ao todo, sendo 6 ex-moradores de rua e 3 agricultores de fora, de Sapé. Para chegar ao registro, duas famílias romperam com aquele grupo e outras três se uniram, inclusive a de Robério. Um técnico do INCRA teria pedido para Robério ser incluído.

Em maio de 2004 conseguiram entrar no programa do governo federal "Plano Safra" ${ }^{13}$, cuja compra é garantida pela Conab (Central Nacional de Abastecimento), para

\footnotetext{
13 "Plano Safra" é o nome do programa de Aquisição de Alimentos da Agricultura Familiar, que se insere no projeto Fome Zero do governo federal, gestão 2003-2006. O programa consiste em o poder público comprar, sem licitação e de acordo com tabela de preços, produtos alimentícios de pequenos agricultores até o limite $\mathrm{R} \$ 2.500,00$ por agricultor/ano. Compra-se do agricultor que utiliza o Pronaf. Um exemplo é a compra de feijão, arroz, milho, trigo, farinha de mandioca e leite em pó feita em convênio com o Ministério do Desenvolvimento Agrário e Combate à Fome (MDA) e a Companhia Nacional de Abastecimento (Conab). O destino da compra é a população carente. O programa baseia-se no artigo 19 da lei 10.696, 02/07/2003, que o institui com o objetivo de incentivar a "agricultura familiar", distribuir produtos agropecuários para
} 
plantio de mandioca, para os moradores de sete lotes. Ficaram na espera outros quatro lotes. Robério foi uma das pessoas que não recebeu o financiamento e saiu do grupo. Zé Bento disse que plantou a mandioca em sociedade com um sitiante de fora do assentamento que realiza o plantio e aquele roça o mato.

Em dezembro de 2004, Walter está com uma plantação de mandioca em seu lote. Disse que quem segura a associação é ele e outra pessoa de fora do assentamento. Esta outra pessoa é conhecida por arrendar áreas no assentamento e queria comprar o lote de Robério. Walter mencionou que pretende manter distancia de pessoas que estão estigmatizados pela maioria do assentamento. São laços e nós refeitos. A associação, ainda com pouco tempo para se avaliar, teve sua rede diminuída. Vale notar, na figura 10, os movimentos e os diferentes momentos de união e desunião entre os moradores que formaram os "Exculhidos" e, depois, a Compartilha, que teve duas fases.

$$
* * *
$$

Para acabar este tópico, vale retomar as trajetórias dos ex-moradores de rua que concordaram em conceder entrevistas sobre sua condição. Os "perfis de carreira" de pessoas como Abelardo, Ivan, Ademir e Jonato (retratado no capítulo anterior) são característicos de uma massa dos trabalhadores braçais do país. Vieram de famílias da zona rural, trabalharam nas cidades como pedreiro, pintor, porteiro, vigia, aprenderam "de tudo um pouco": roçar, erguer parede, fazer uma instalação elétrica; enfim, são os famosos "pau para toda obra". Sem contar o quanto eles andaram, a procura de terra, de trabalho ou, às vezes, um perambular sem direção pré-definida. Aparecido, por exemplo, calcula ter percorrido a pé quase três mil quilômetros pelo Brasil. As habilidades aprendidas nas cidades ou no trecho, como dizem, os ajudam no assentamento. Nesse quadro, a trajetória de Walter (retratado no capítulo anterior) parece ser um "privilégio" por permanecer como proletário por vinte e dois anos. Igualmente, Ednardo ficou por 28 anos no mesmo emprego na cidade e também teve origem no campo. Jandira (retratada no capítulo anterior) também teve origem familiar na lavoura, da zona da mata pernambucana, e na cidade de S. Paulo trabalhava como doméstica. Robério não teve assumidamente uma origem rural, mas passou muitos anos trabalhando em fazendas no Mato Grosso. Jonas, desde o nascimento, passou muitos anos trabalhando em fazenda e quando foi para S.

população em situação de insegurança alimentar e formar estoques estratégicos. Ver: www.fomezero.gov.br, acessado em 29/12/04. 
Paulo trabalhou como vendedor ambulante. Zé Bento é o único que nunca teve ligação com a terra ${ }^{14}$. Quanto ao local de nascimento, de 9 entrevistados, 5 nasceram no estado de Minas Gerais, 3 no nordeste (Sergipe e Pernambuco) e um no interior de São Paulo.

Entre as razões associadas aos motivos de ter ido viver nas ruas, há a falta de trabalho ou de possibilidade de ter acumulado um rendimento suficiente para ter algum patrimônio ou terra. O morar na rua aparece, em segundo lugar, como uma passagem temporária para quem migrou para São Paulo sem ter emprego nem moradia e não teve mais condições de permanecer em albergues.

Quanto a entrar para o MST, a resposta mais comum era de que foi a única alternativa que apareceu. Na falta de alternativa, ter um pedaço de terra era uma saída. A maioria foi contatada por militantes da Fraternidade Povo da Rua ou do MST. Outros foram procurar os militantes porque ouviram falar das ocupações por amigos da rua.

\section{Redes: outra associação e um grupo}

A movimentação de três ex-coordenadores é destacada porque, mesmo sendo alvos de ataques, teceram a maior rede no assentamento. Rosa, desde o início, tinha os familiares e alguns amigos como aliados. Passou por um período de isolamento devido às acusações sofridas, em 2002. Considera que alguns são "criminosos". Disse que, no começo da vida no assentamento tentou ajudar Walter, mas depois este brigou com ela. Em 2002, havia optado pelo recolhimento, estava descrente de coletivos e de instâncias públicas por ali. Defendia muito Carlos, mas não trabalhavam juntos. Mas, na virada de 2002 para 2003, forma um "semi-coletivo" com seus familiares. Carlos desde o início da ocupação mantém sua família e compadres unidos e seu exemplo, posteriormente, contagia. Em 2001, Frederico defendia Carlos, mas não se associava a ele. Trabalhava, em 2002, somente junto com sua esposa e com os dois filhos casados que também estão assentados ali e, em 2003, virou presidente de uma associação.

\section{Associação Agro União}

Mais de dez famílias começaram a se reunir em janeiro de 2003 e registraram uma associação em 2004 presidida por Frederico, com doze famílias. Como só Frederico tinha experiência anterior com associação, virou o presidente. É a associação Agro União, que

${ }^{14}$ Como Zé Bento não quis se identificado como ex-morador de rua, sua trajetória neste sentido específico não será retratada. 
tem estatuto registrado em cartório e contador, e tem como objetivo a cooperação na produção e na comercialização. Cada um produz em seu lote e vendem juntos. Eles se reúnem mensalmente. Entre os associados, a maioria é de famílias que defendiam a moradia nos lotes, ao invés de no projeto de agrovila, em 1999-2000. Querem viver e trabalhar no lote, mas sabem que não podem ficar isolados. A maior parte tem interesse na produção de leite e fez no lote pasto rotacionário (sistema de Voisin), como aparece na figura 6. Pretende comprar máquinas agrícolas para uso dos associados e montar um tanque de resfriamento armazenamento de leite. Em 2004, iniciaram o plantio de mandioca em 1 ou 2 ha em alguns lotes, com projeto feito com apoio técnico do MST e baseado no programa do governo federal "Plano Safra" e discutiram o que mais podem plantar em comum. A produção de leite em 2004 não foi suficiente para comercialização, mas consideram que o avanço na organização política foi bom. A mandioca foi colhida em sistema de mutirão, ou troca de dias de trabalho: todos os associados trabalharam em todos os locais plantados, sem haver pagamento em dinheiro.

No final de 2004, mais duas famílias se uniram a associação. Estas duas famílias acompanharam desde o começo as reuniões do grupo, mas estavam reticentes com o trabalho em associação. Os moradores de dois outros lotes (genro e sogro, respectivamente), que têm parente na associação, acompanharam as reuniões de formação do grupo, mas desistiram no momento da formalização da entidade.

A associação conseguiu adquirir um trator e um carreto, em dezembro de 2004, através de uma organização não-governamental (ONG) italiana. Houve reuniões mensais e, ao longo do ano, a associação se filiou a Agência Regional de Comercialização (Arco) do município que auxilia pequenos agricultores, tendo ocorrido uma série de encontros entre as duas entidades. Esses contatos abriram caminho para a aquisição do trator. Tem ligação também com o padre da Pastoral Santa Fé para uso de caminhão e possíveis financiamentos. Conseguiu também um ponto de comercialização do MST, ao lado do Ceasa (Central de abastecimento, em São Paulo). É a rede se ampliando e se fortalecendo. Ver, na figura 11, a distribuição dos lotes daqueles que compõem a associação.

\section{O grupo das estufas de pimentões}

O cultivo de pimentões (e, às vezes, de tomate e pepino) em estufas com irrigação por gotejamento aparece no assentamento como uma instância de reunião de famílias. É uma forma de produção voltada, predominantemente, para a venda e, assim, para a obtenção dos bens materiais que não são resultantes da atividade agropecuária local. 
A família extensa de Carlos, composta pela família nuclear (mulher e três filhos solteiros), quatro filhos casados e mais as famílias nucleares de dois compadres, vem trabalhando junto desde a ocupação e continua depois que mudaram para o lote onde mora reunida, numa espécie de mini-agrovila, conforme observa-se no foto 4. Em 2002, uma filha dele casou-se com um jovem do assentamento e se mudou para o lote do sogro. A relação de parentesco e de compadrio se ampliou mais. Ao todo, eles mobilizam sete lotes no assentamento, sendo que há estufa de pimentão em dois.

Houve uma primeira tentativa de trabalho de forma coletiva com pimentão em estufa numa área comum, entre 1998 e 2000, antes de cada família mudar para seu próprio lote. Em 1998, Carlos foi responsável por administrar uma doação de 12 mil reais para o assentamento. Com isso, os moradores ergueram uma estufa de mil metros quadrados para plantio de pimentões. Em torno de 30 chefes de família participaram do trabalho na estufa. Porém, não tinham experiência com estufa nem com pimentões. O terreno não apresentava a declividade necessária e empoçava água no interior da estufa, gerando praga no pimentão. Como optaram por cultivo orgânico, não souberam como combater a doença a tempo e perderam a sequiência da safra ${ }^{15}$. As pessoas receberam de Carlos por dia trabalhado, mas não ficaram satisfeitas, lentamente abandonaram o grupo e passaram a boicotar suas posições em assembléias.

De 2000 para 2001, a família extensa de Carlos levou a estrutura da estufa para o lote onde eles foram morar e passaram a trabalhar juntos naquele local. Nesse período, Vladimir - cuja história será vista a seguir - trabalha junto os parentes de Carlos, em nome dos ideais coletivistas do MST; porém, ele deixa o grupo em 2001. (Vladimir fica sozinho no lote, mas não deixa de ser um nó na rede de Carlos e este na daquele.) Entre 2002 e 2003, o grupo conseguiu erguer mais uma estufa e, com acertos e erros, começaram a dominar a técnica de cultivo. A segunda estufa de $1000 \mathrm{~m}^{2}$ foi construída com ajuda financeira de um padre da Pastoral Santa Fé, na grande S. Paulo, que conseguiu doação com a condição de que o trabalho seja em grupo ${ }^{16}$. Em 2004, a família começou a erguer mais duas estufas no mesmo lote, somente com o rendimento da safra do ano, sem auxílio financeiro externo. No final desse mesmo ano, um dos membros do grupo, compadre de Carlos, deixou de participar do semi-coletivo das estufas por problemas pessoais.

\footnotetext{
${ }^{15}$ A primeira safra de pimentão ocorre após 4 meses do plantio, o pé prossegue dando frutos por cerca de 8 meses até morrer. O ciclo é, geralmente, o seguinte: plantio em maio e colheita de agosto até março.

${ }^{16} \mathrm{O}$ padre disse que os moradores precisam ter "redes" para se desenvolver.
} 
O grupo de Carlos divide o resultado da venda da produção de pimentão por dia de jornada e trabalha junto nos demais lotes da família, onde não há moradias. Nos dois lotes localizados na área dos tocos de eucaliptos há cultivo de cana, milho e capim napiêr numa metade destocada e outra, onde há tocos e eucaliptos, é deixada para pasto. Em outros dois lotes, a maior parte é usada para pasto e há cultivo de milho, cana e, alternadamente, feijão, conforme pode-se observar na foto 5 . No lote de um compadre, quando era trabalhado pelo grupo, havia pasto, cana, milho, feijão, mas a partir do final de 2004, devido ao afastamento do proprietário em relação ao grupo, uma parte do lote está com plantação de melancia feita por pessoas de fora.

No lote onde todos os membros do grupo moram, além das casas e das estufas, há hortas, pomar, galinheiro, pasto e áreas para plantio de cana, milho, feijão, arroz e demais produtos para consumo.

Num outro lote, mora uma família extensa de outro compadre de Carlos, composta de três famílias nucleares em três casas distintas. O casal mais velho e um filho adulto moram numa casa; uma das filhas de Carlos, o marido e uma filhinha moram noutra, e, numa terceira casa, uma filha daquele casal, o marido e uma filhinha. Todos trabalham juntos no lote onde há duas estufas de $500 \mathrm{~m}^{2}$ cada, pasto e os demais cultivos. Ver o desenho do sítio na figura 7. Eles fazem parte do grupo da estufa e da associação Agro União.

A partir do exemplo dado pela família de Carlos, o trabalho com estufas de pimentão se consolidou no assentamento com a entrada de outras famílias com o objetivo da atividade em grupo. Rosa desde o começo da luta manifestou ideais de união e solidariedade e até metade de 2001 conseguiu ainda manter sua família ampliada e mais uns poucos amigos trabalhando juntos, porém, os amigos saíram e ficou só a família. No segundo semestre de 2001, o desânimo lhe abateu devido à acusação de desvio do dinheiro de fomento. Em 2002, Rosa resolveu sair do desânimo e com sua família extensa composta de três famílias nucleares: a dela, a do irmão e a da cunhada -, que já era um grupo formado, começou a se organizar para trabalhar com estufa de pimentão. O padre, que já havia financiado a construção da estufa de Carlos, dá o dinheiro para instalar uma estufa no lote dela. O padre consegue dinheiro desde que seja para se trabalhar em grupo.

O grupo é composto por oito forças de trabalho, que se revezam diariamente na estufa conforme uma escala de trabalho. Quando é exigido mais trabalho, como na colheita, por exemplo, todos comparecem. Eles dividem as sobras proporcionalmente aos dias trabalhados por cada um, descontam as faltas e guardam $20 \%$ para reinvestir no 
próximo ciclo. Segundo Rosa, o grupo dela é o único a fazer essa reserva de recurso. Como Rosa é amiga de Carlos foi fácil seguir o exemplo deste vizinho e reunir as famílias para troca de experiências com as estufas.

Rosa e familiares construíram uma segunda estufa (cada uma das três famílias investiu 1500 reais de 2.600 que receberam para custeio de alimentação de gado), em 2004. O marido de Rosa avalia que com uma terceira estufa, as três famílias estarão bem. (A produção esperada de uma estufa de $1.000 \mathrm{~m}^{2}$ é de mil caixas. No início de 2004, o preço obtido por caixa variou entre 8 e 25 reais. Na segunda estufa, plantaram em janeiro e colheram em maio 400 caixas; o preço por caixa chegou a 50 reais.) Na foto 6, é possível visualizar a produção de pimentão na estufa.

Além das duas estufas, que ficam no lote de Rosa, o grupo planta coletivamente mandioca no lote do irmão dela. Individualmente, em cada um dos três lotes plantam mandioca, cana, milho e criam gado. No lote de Rosa, por exemplo, há cerca de 30 cabeças de gado para consumo de leite e carne da família nuclear.

No mesmo ano que o grupo anterior se formou, a família ampliada de Aparício (três famílias nucleares: a dele e as de duas filhas casadas) e a do lote vizinho a Rosa também formaram um grupo para trabalhar com pimentão e ergueram uma estufa num dos lotes. Em 2004, eles iniciaram a construção de uma segunda estufa no mesmo lote. Todas as famílias trabalham juntas todos os dias e dividem a venda em partes iguais. A família que não tem parentesco deixou o grupo no final de 2004.

Esses três semi-coletivos formam um grupo desde de 2002, cujos representantes se reúnem mensalmente para discutir a produção e os planos. Eles compram as sementes e os insumos e comercializam juntos. Assim, através da produção agrícola se forma uma instância de reunião em que os moradores se acostumam a tratar os assuntos coletivamente. Além de reuniões mensais com representantes dos três semi-coletivos, cada um destes faz reuniões regulares para programar as atividades.

A rede que unia três dos antigos coordenadores - Frederico, Carlos e Rosa - se fortaleceu, um semi-coletivo e uma associação estão atados. Há duas famílias que pertencem ao grupo das estufas e à associação, de modo que temos uma interface entre os dois que amplia a rede de cada um. Ao todo são 24 famílias em rede, até o momento. As duas famílias que se desligaram em 2004 dos grupos podem, potencialmente, ser elos dessa rede. Portanto, a maioria do assentamento está, no momento, atada. Vale destacar que com a Compartilha não há conexão. Há, na figura 11, a configuração geral do assentamento mostrando das duas associações e os grupos das estufas. Na figura 12, observa-se a 
contraposição, decorrente dos ataques judiciais, entre as redes formada pelas famílias que estão na associação Agro União com o grupos das estufas e as famílias dos "Exculhidos"/ Compartilha. Essa representação na figura 12 sobrepõe diferentes momentos (2002-2004) da história desses dois grupos e mostra a configuração daquela fração de território, apontando para a tendência à polarização entre uma rede maior (no número de nós e na coesão) e mais forte (no sentido de intercâmbio com o exterior do assentamento) e outra menor e mais fraca.

\section{Sozinhos no lote}

Entre aqueles que não estão diretamente em algum grupo ou associação, há atualmente 8 famílias. Vale observar nelas a possibilidade de formar, ou não, laços nas redes existentes. Há também o caso de pessoas sozinhas no lote e/ou de casais que chegaram a fazer parte da associação Compartilha e, atualmente, ficaram isolados. Um caso exemplar de família sozinha no lote, mas conectada a maior rede do assentamento, é a de Vladimir.

Relembrando, quando cada família foi para o lote definitivo, em 2000, Vladimir era um dos que ainda trabalhava junto com Carlos; porém, em pouco tempo romperam. Mesmo assim, ele, por amizade, está na rede de Carlos. O interessante da trajetória de Vladimir é que ele foi para a luta como dirigente do MST. No acampamento conheceu Iara, que tinha um filho. Casaram-se e têm dois filhos juntos. Ele é natural do sul da Bahia, onde seu pai era dono de terra. Seu pai foi vendendo as terras para os irmãos até ficar sem nada. Quando ele tinha por volta de nove anos, a família se mudou para a cidade. Lá ele trabalhou no comércio e na roça. Quando seu pai morreu, em 1991, a família se mudou para Carapicuíba/SP, ele estava com 18 anos. Demorou até conseguir um emprego de garçom, depois trabalhou na indústria, na construção civil até não conseguir mais emprego. Passaram-se quase dois anos e um primo o chamou para trabalhar numa fazenda que havia comprado, no interior do estado. Ficou por lá até conhecer um grupo do MST que foi fazer trabalho na região e participou de uma ocupação em Getulina/SP, em 1993. Ficaram por mais de dois anos em acampamentos sucessivos sem conseguir desapropriação. Foi para outra ocupação, onde conseguiram a desapropriação. Então, Vladimir foi para uma manifestação na sede do INCRA em SP, quando o Movimento lhe designou para ajudar na ocupação em Alencar/Irene, que geraria o assentamento Clarice Lispector.

Vladimir, após largar a união com o grupo de Carlos, recolhe-se em seu lote. Voltase para o trabalho para sustento da família, que se ampliou com os filhos. Sua mulher ainda 
participa de comissões. Mas, ele que foi colaborar na luta do Clarice Lispector como militante do MST, cortou qualquer participação em grupo. Ele diz que o lote "aliena" porque tem que torná-lo produtivo para sustentar a família (e até pagar o trabalho de um ajudante) e, por isso, não sobra tempo para participar da política no assentamento. Ao mesmo tempo, coloca que a participação no grupo de Carlos era insustentável porque questões de família predominavam nas decisões coletivas sobre o grupo. Assim, argumentava que os grupos internos, em 2002, eram formados exclusivamente por parentes, exceto o de Walter.

Graças ao sorteio dos lotes, a família de Vladimir ficou com um dos melhores porque era onde morava o gerente da fazenda. Então, já tinha casa com luz elétrica, curral, barracões, lago e chiqueiro. A principal atividade no lote é gado, possui 40 cabeças. Entre 2003 e 2004, fez uma parceria para plantio de melancia e, após a safra, obter uma braqueara de melhor qualidade para o gado pastar. Define parceria da seguinte forma: ele e o parceiro dividem meio-a-meio as sementes, os insumos e o trabalho de plantio (mesmo tendo que pagar mão-de-obra extra) e tenta que a venda também seja dividida por igual. Assim ele diferencia a parceria do arrendamento em que, neste caso, os arrendadores não trabalhariam no plantio e nem dividiriam os custos.

Temos, assim, o caminho do militante sozinho que constitui família e tem de sustentá-la. A condição "camponesa" fez com que se afastasse da luta coletiva para garantir a vida familiar. Ele se justifica como sendo uma missão tornar o lote produtivo para mostrar que a reforma agrária dá certo. Mesmo, no momento, não fazendo parte de algum grupo, Vladimir participa das reuniões e assembléias do assentamento, defende aqueles que estão organizados em grupos porque estão mostrando resultados e ataca os que são "vagabundos" e querem vender o lote.

Nos dois menores lotes do assentamento, com 4 ha e 7,3 ha, moram dois homens solteiros. Segundo depoimento de técnicos do INCRA ao pequisador, eles foram assentados porque seria "injustiça" deixá-los de fora; por isso, criaram o "pára-rural", lotes menores que a média, para atender a casos como esses. Os dois homens são tidos como "pinguços". Um deles, com base em sua vida na cidade, ergueu sua casa, mas, mal tem um pomar ao lado dela. Não tem cultivo no lote. Ele ganha algum dinheiro trabalhando para os outros e com o uso do pasto de seu lote para gado de fora do assentamento. O outro morador vive ainda em barraco de madeira e quase não tem plantações. Já manifestou interesse em "vender" o lote. Além de não se associarem aos demais moradores, os dois raramente participam de reuniões ou assembléias do assentamento. 
Outros que não fazem parte de nenhum grupo porque preferem o "individual" é a família Jonato e Jandira. A trajetória deles já foi tratada no capítulo anterior. Vale mencionar que eles depositam confiança em membros da associação Agro União. Situação semelhante é a das famílias de outros dois lotes, mãe e filha respectivamente, que não estão em nenhum grupo, mas participaram das reuniões de organização da Agro União e têm amigos e parentes nela. Há um belo pomar num desses dois lotes, mas como localiza-se nos tocos, o casal trabalha na lavoura do genro. Sem entrar na associação, as famílias destes dois lotes ampliam a rede daquela organização.

Vizinho ao lote da família Jonato e Jandira, está o lote de uma família composta pelo casal e cinco filhos. O chefe da família foi um dos coordenadores de grupo da fase de acampamento e de pré-assentamento, mas prefere trabalhar sozinho em seu lote porque considera ruim a diversidade de costumes e de práticas agrícolas existentes no assentamento decorrente de ter gente de vários estados do país. Já registrou queixa na polícia contra seu vizinho por briga derivada do problema de gado deste ter derrubado a cerca divisória entre os lotes. Carlos é seu compadre e a família de um irmão mora no assentamento e compõe um dos semi-coletivos de estufas. Porém, essa inserção familiar e de compadrio não o coloca necessariamente numa das redes do assentamento.

Entre aqueles que não estão em nenhum grupo ou associação, temos, por último, Ednardo, cuja trajetória foi descrita anteriormente. Ele e a mulher moram num lote e têm uma filha casada com o filho de uma vizinha, que moram em outro lote. Ednardo é o único morador que é atacado por quase todos do assentamento. Portanto, traça sua rede por fora. Declara ter amigos no trabalho pastoral na cidade vizinha. Foi acusado por diferentes pessoas de ter se unido a outras duas moradoras para supostamente tramar a saída de Ivan do assentamento. Se esta é uma rede, ela tem laços frouxos diante da maioria dos assentados.

Por fim, cabe mencionar que entre as pessoas tidas como "individuais" não há só homens sozinhos e que alguns destes estão na organização Compartilha. Mas, no final do ano de 2004, esta associação isolou alguns de seus membros.

A força das 8 famílias que estão fora de qualquer grupo em se manter no assentamento depende também de sua capacidade de tecer e fortalecer redes, independentemente de expressarem maior ou menor grau de campesinidade, conforme definição de Woortmann (1990). Ou seja, tecer uma rede ampla com laços fortes pode ser mais "determinante" do que um ethos de campesinidade para a permanência e desenvolvimento no assentamento. 


\section{As categorias de acusação e o ethos camponês}

Ao percorrer as redes, encontra-se também um traçado de ataques e acusações mútuos. As fofocas tecem redes, que configuram o espaço. Cabe então mostrar e agrupar as categorias de acusação presentes no cotidiano do assentamento.

Uma das acusações mais ouvidas por todos os lados é "vagabundo" ou "preguiçoso", em que, por oposição, o emissor se afirma como trabalhador, como aquele que faz o lote se tornar digno da luta pela reforma agrária. Uma derivação dessa é "no lote dele não tem nem uma galinha, um frango", desqualificando como camponês aquele que não teria o mínimo dos padrões de vida num sítio. Neste sentido, o fato de "ser sozinho" também é um juízo contra pessoas que não teriam condições de trabalhar devidamente o lote. Próximo a essas idéias está a categoria de fazer "arrendamento", proferida contra quem não trabalha no lote e só o aluga para o trabalho de terceiros externos ao assentamento. Além de "não trabalhar", ataca-se a irregularidade contratual com o INCRA de não poder arrendar o lote. Por oposição, a "parceria" é justificada como uma necessidade devido a falta de recursos para, por exemplo, ter um bom pasto, como expresso na fala de Vladimir citada anteriormente. Enquanto as categorias "vagabundo" e "ser sozinho" aparecem ao longo de todo o trabalho de campo, a oposição "parceria x arrendamento" foi uma marca dos dois último anos, quando a maioria dos assentados quer "regularizar" o assentamento. Em primeiro lugar, todas essas categorias podem ser agrupadas na idéia de "ser camponês", mesmo que não seja este o termo usado pelos assentados. "Ser camponês" sintetiza a idéia de trabalhador, com família, que é capaz de produzir no sítio.

Outro tipo de acusação é contra as pessoas que "sujam o Movimento", o que envolve vários julgamentos associados àqueles que cometem irregularidades, que são "bêbados" e não trabalham ou que se envolvem em fazer queixas à Justiça. Em segundo lugar, pode-se agrupar uma série de acusações em julgamentos morais, como "ser mentiroso"; "falar, falar e não fazer", ou "ser papudo"; "não assumir os erros"; "ser cabeça fraca, ir pela cabeça dos outros"; "um homem daquele jeito não pode ser da Igreja"; “incriminar o assentamento"; “dever pagamento por dias de trabalho". Por exemplo, um morador dispara, em muitos momentos, que há muita mentira no assentamento, que fulano é mentiroso; porém, ele também recebe a mesma acusação. Também falam que ele é papudo porque falaria demais e não mostraria resultado de sua verborragia. Quando se criou uma comissão para acompanhar as irregularidades no assentamento, alguns foram 
acusados de "não assumirem os erros". Um julgamento proferido constantemente é de ser cabeça fraca geralmente se referindo àqueles que procuram a Justiça para acusar os demais assentados; seriam manipulados por outras cabeças (um ou dois indivíduos específicos) que só querem "incriminar o assentamento". O mais interessante da categoria cabeça fraca é que lados adversários emitem o mesmo julgamento contra as mesmas pessoas e, ao mesmo tempo, alguns que fazem uso da desqualificação também a recebem. Na dinâmica de ataques mútuos, há um indivíduo que recebe acusações de muitos outros e, conseqüentemente, procura alianças fora do assentamento, na pastoral católica municipal; então, os outros dizem "um homem daquele jeito não pode ser da Igreja". Por fim, como é comum vizinhos trabalharem um para o outro para erguer parede, roçar, limpar pasto, consertar cerca, há queixas de "não receber pagamento de dias trabalhados".

Deduz-se que nas acusações recíprocas está em jogo a manipulação da definição de camponês. Com base em distintos trabalhos sobre o tema (como referência, ver CANDIDO, 1998; WOLF, 1969; WOORTMANN, 1990; MOURA, 1986; CHAYANOV, 1974 entre muitos outros), é possível estabelecer uma síntese do que consiste a campesinidade: a ligação simbólica com a terra, o trabalho familiar e a religiosidade. São três elementos interconectados: a terra é trabalhada pela e para a família e o sentido simbólico do arar, semear e colher os frutos constitui e é constituído pela religiosidade. À parte a relevante discussão sobre classe social e subordinação ao capital, a ordem moral também é um elemento marcante do camponês. Portanto, vê-se nas categorias mencionadas um peso dado pelas acusações morais: a mentira, a dívida e o ser heterônomo. No uso generalizado do termo "vagabundo", afirma-se uma identidade de trabalhador por oposição ao outro que é não-trabalhador. Ao se apontar uma alteridade da vagabundagem, se está afirmando uma identidade marcada pela moral do trabalho; é um "eu" camponês latente.

O par "parceria x arrendamento" também merece destaque. A fala de Vladimir, já mencionada, fez a distinção entre os dois termos. O fato é que um grande número de moradores teve ou tem necessidade de auxílio externo para trabalhar no lote, seja de alguém com dinheiro e/ou com maquinário. Porém, enquanto a parceria se dá por necessidade, o arrendamento é taxado como irregularidade contratual com o INCRA. Portanto, pode-se ler na justificativa da parceria uma forma de se manter como "camponês", enquanto o arrendamento seria colocado como uma forma não digna, ou merecedora, de ser assentado da reforma agrária. Este tema do arrendamento será tratado novamente no próximo capítulo. 
Se um elemento da campesinidade é a família, os homens sozinhos estariam fora deste registro. Por isso, assentá-los foi uma fonte de tensão, que reverbera até hoje. No entanto, há homens sozinhos que, aos poucos, constroem famílias, outros que configuram seu lote com as características de um típico sítio camponês (casa contornada por horta, pomar, galinheiro, chiqueiro e a área da lavoura) e alguns que não conseguem trabalhar o lote todo. Mas, este último caso não é exclusividade dos homens sozinhos. Portanto, o ethos camponês pode ter elementos que fortalecem e outros que enfraquecem a complexidade vivida num assentamento de reforma agrária. Por exemplo, o ethos camponês manifesto em Vladimir, que tem família e lote para cuidar, o atrapalharia em ter tempo para militar pelo MST. Outro exemplo, um morador critica muitos assentados que são indivíduos sem famílias de serem "vagabundos", é o caso de um tipicamente "camponês" definindo, por oposição, o seu ethos. Se depender da posição dele, quase todas as pessoas ligadas a associação Compartilha ficariam de fora da definição de agricultor "honesto e trabalhador".

$\mathrm{Na}$ associação presidida por Frederico ou nas famílias que trabalham juntas na produção de pimentões encontram-se as marcas camponesas explícitas: a luta pela terra tem um sentido religioso e a unidade de produção é voltada para a família (mesmo quando é para obter dinheiro com a venda). No entanto, ficar preso a determinantes de campesinidade, sejam quais forem (econômicos e/ou culturais) mostra-se como uma armadilha, porque eles são ruídos ouvidos constantemente de todos os lados no assentamento que reproduzem brigas e divisões. Quem resolveu ir para a terra é camponês. O ethos camponês não deveria ser postulado como a essência ${ }^{17}$, mas como uma situação: este é um ponto de partida deste trabalho. "Dar certo" no assentamento vai depender do jogo entre isolamento e redes.

\section{A dinâmica das invalidações recíprocas e seu oposto}

Pelo descrito do início do trabalho de campo, encontrou-se no assentamento retratado uma situação semelhante àquela chamada de "invalidações recíprocas" por D’Incao e Roy (1995). Essa situação consiste de uma dinâmica de acusações mútuas, em que as pessoas do assentamento ficariam culpando e atacando umas as outras, a ponto de

17 Chayanov (1974 [1925]: 34-40), por exemplo, baseia seu trabalho na compreensão da "essência" organizativa do trabalho familiar. Mas, faz a ressalva que sua teoria não tem pretensão de aplicação universal e de abarcar todas as formas de empreendimentos camponês. 
travar a possibilidade de ações conjuntas. Por se constatar um cenário próximo ao descrito há dez anos, parece que as "invalidações recíprocas" são dinâmicas comuns nos assentamentos. Um entrevistado, por exemplo, é capaz de tecer críticas violentas a um outro morador e, logo em seguida, dizer que o maior problema no local é a fofoca e a falta de confiança mútua. Os assentados percebem e interpretam a dinâmico das invalidações, quando, por exemplo, Aberlardo fala em negação.

Como esta tese dialoga com a tradição dos conflitos sociais ${ }^{18}$, que estabelece o conflito como base inerente das relações sociais, as observações anteriores eram, em certa medida, esperadas; assim, não seriam novidades porque estavam contidas na premissa metodológica. Porém, uma dinâmica conflituosa que tende a causar invalidações recíprocas é algo que precisa ser analisado. As invalidações recíprocas eram a marca do assentamento entre 2001 e 2002. No entanto, a consolidação de redes gerou duas associações e um grande grupo. Assim, as invalidações entraram em declínio, mas restam ainda entre a rede de 24 famílias e a Compartilha.

Nesse sentido, a noção de D’Incao e Roy (1995: 68) segundo a qual as “invalidações recíprocas” são próprias das relações de dominação é aplicável parcialmente no caso aqui estudado, porque ocorre o seu oposto também ${ }^{19}$. Primeiro, há no assentamento pesquisado situações em que as invalidações recíprocas se voltam também contra as formas de dominação. Segundo, as invalidações não impediram o tecer redes, que se consolidaram e geraram organizações. As invalidações rasgam ou dificultam a costura de redes, mas não impediram o surgimento de organizações como as duas associações e o grupo das estufas.

\section{Algumas inferências}

Como os moradores de rua entram para luta pela terra sozinhos ou apenas com a família nuclear, eles não têm laços de parentesco no assentamento. O parentesco é um forte elemento na formação dos grupos no assentamento. Pelo constatado, os grupos são

\footnotetext{
18 Num trabalho anterior (JUSTO, 2002: 51-4), expus a contribuição da chamada tradição dos conflitos sociais. Com essa perspectiva teórica pode-se rejeitar a idéia de que as intrigas, as fofocas, as invalidações etc. são peculiaridades daqueles presos à ideologia da dominação.

19 Pretende-se retomar o diálogo com o trabalho de D'Incao e Roy (1995) no sétimo capítulo quanto à questão do papel do pesquisador como agente externo na mediação dos conflitos internos.
} 
formados pelos seguintes critérios, em ordem de importância: parentesco, amizade/afinidade, vizinhança ${ }^{20}$.

Para o MST ser uma alternativa para os moradores de rua, estes devem estar fortalecidos, de modo que entrem para a luta - para a conquista de fração de território com poder de formar e acionar redes. Vale lembrar que o termo "alternativo" tem o sentido da economia solidária. Portanto, não basta tirar as pessoas das ruas, mas sim possibilitar que elas trabalhem em grupos e em redes geridas sem hierarquia e sem o assalariamento típico da relação capital - trabalho. Neste sentido, o papel não recai somente sobre o MST, mas também nos ombros dos apoiadores e demais elos das redes dos assentados. Possibilitar que os assentamentos, com ex-moradores de rua ou não, se constituam como núcleos econômicos não-capitalistas é uma tarefa por realizar e a chamada territorialização da luta pela terra é condição necessária, mas não suficiente para tal. Voltarei a este ponto no capítulo sete.

No próximo capítulo serão retomados e aprofundados os estudos das redes no assentamento. Voltar-se-á para as outras redes formadas e para as formas de gestão de conflitos.

\footnotetext{
${ }^{20}$ Sobre a formação de grupos e as relações de parentesco, ver Rapchan (1993) e Carvalho (1998 e 1999).
} 


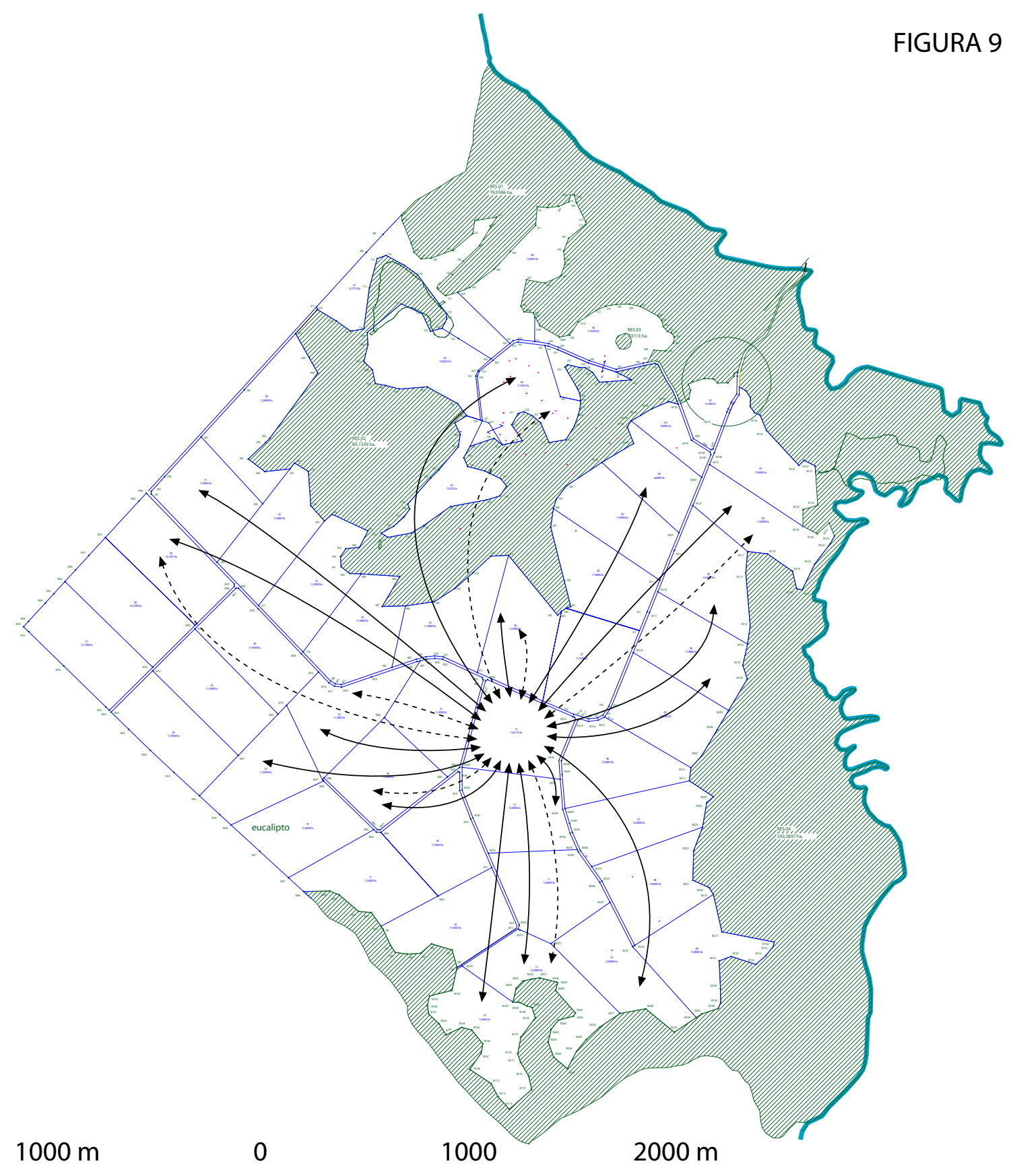

Legenda

Área agrícola (47 Lotes)

Reserva ambiental

- Rio

$\longleftrightarrow$ Alianças 
Movimentos de união e desunião: grupos Exculhidos-Compartilha

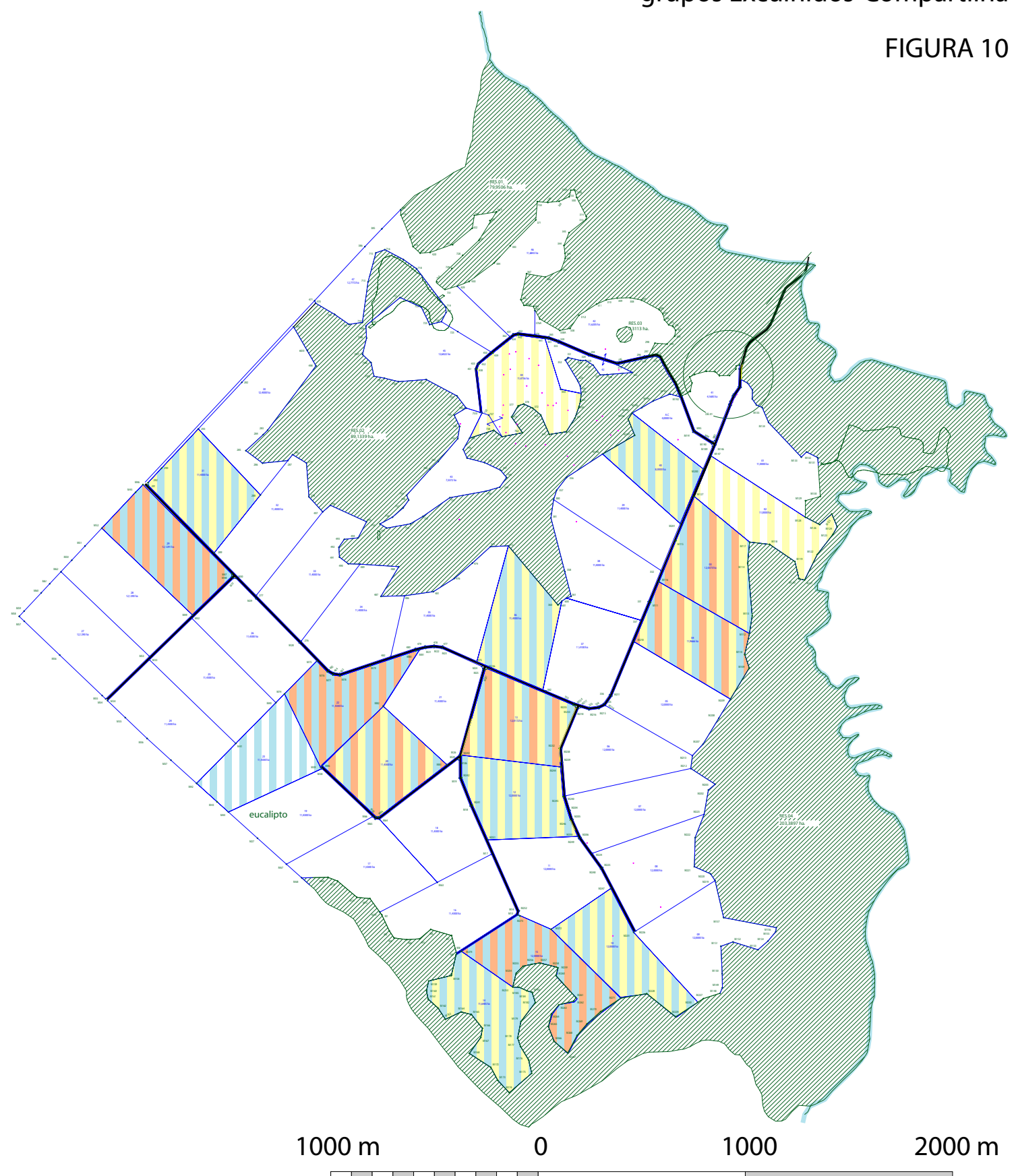

Legenda

Área agrícola (47 Lotes)

Reserva ambiental

- Rio

Fases de composição dos grupos

Exculhidos (2002)

Partilha I (2003)

Partilha II (2004) 
Configuração espacial das associações e dos grupos das estufas

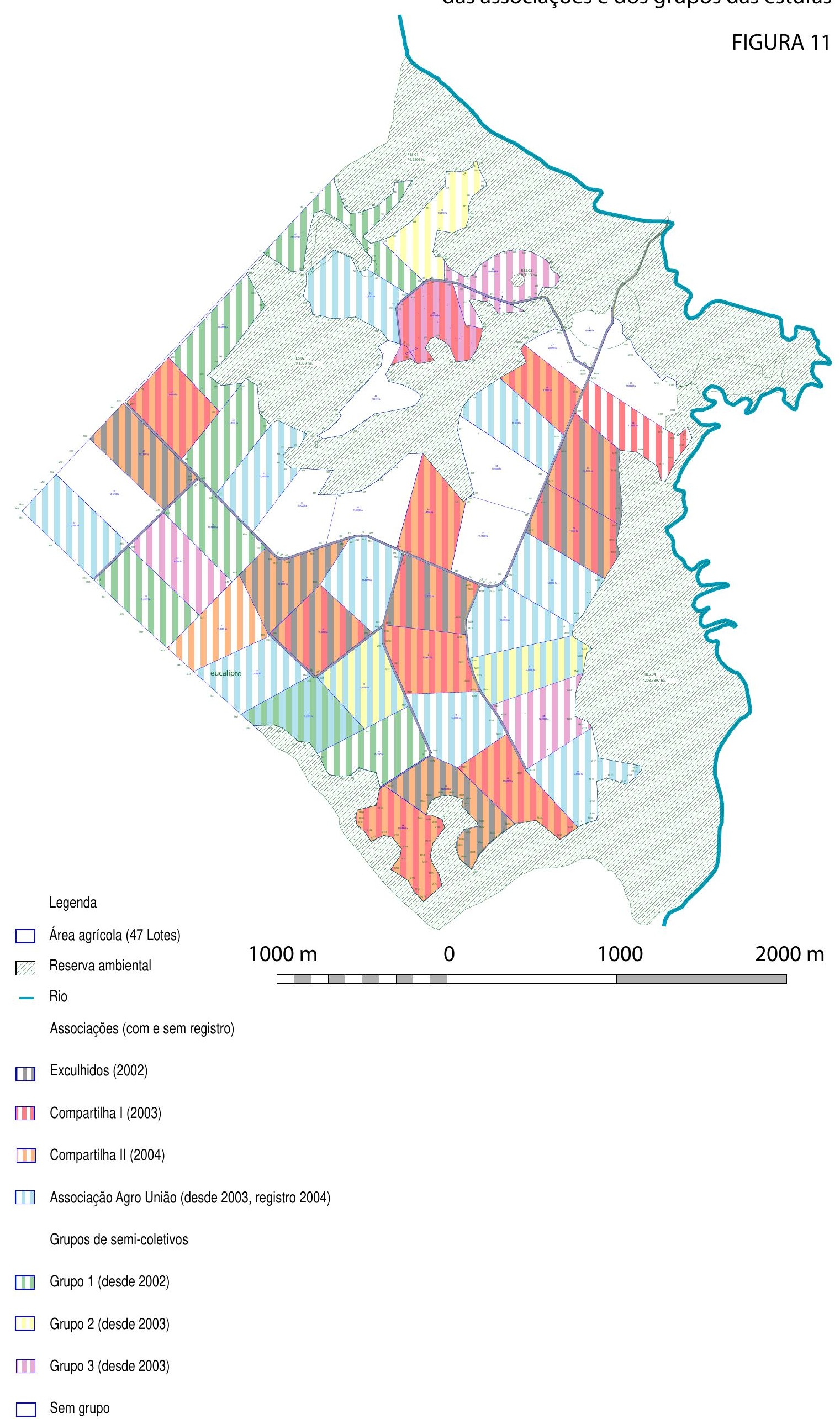


A configuração do assentamento: as duas redes e as ações judiciais

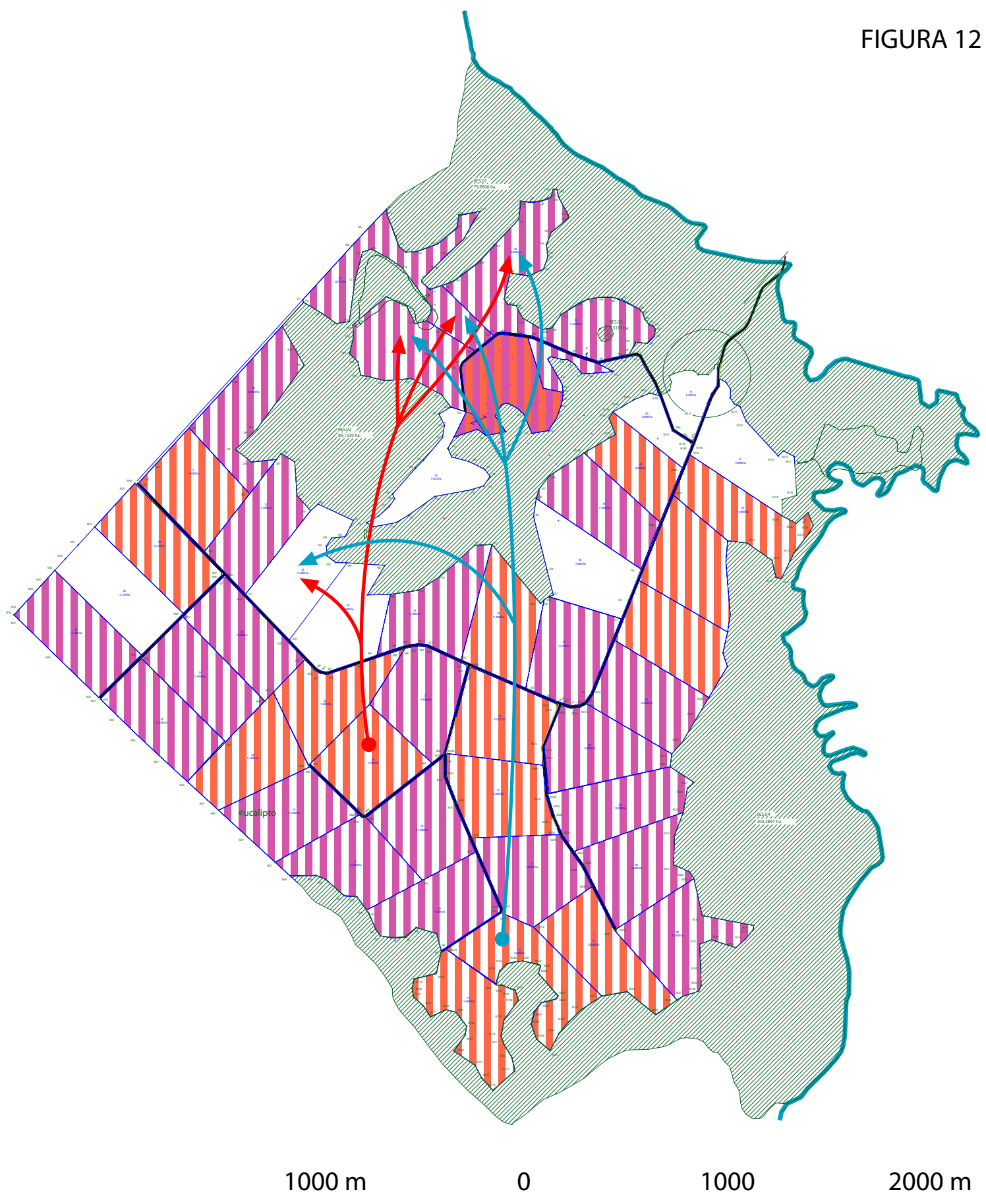

Legenda

$\square$ Área agrícola (47 Lotes)

Reserva ambiental

- Rio

Uniões

Ш Associacção Agro União + Estufas

Exculhidos e Compartilha I e II

Compartilha I e Estufas

Sozinhos

Ações legais

- Direção da ação judicial

- Direção do boletim de ocorrência 


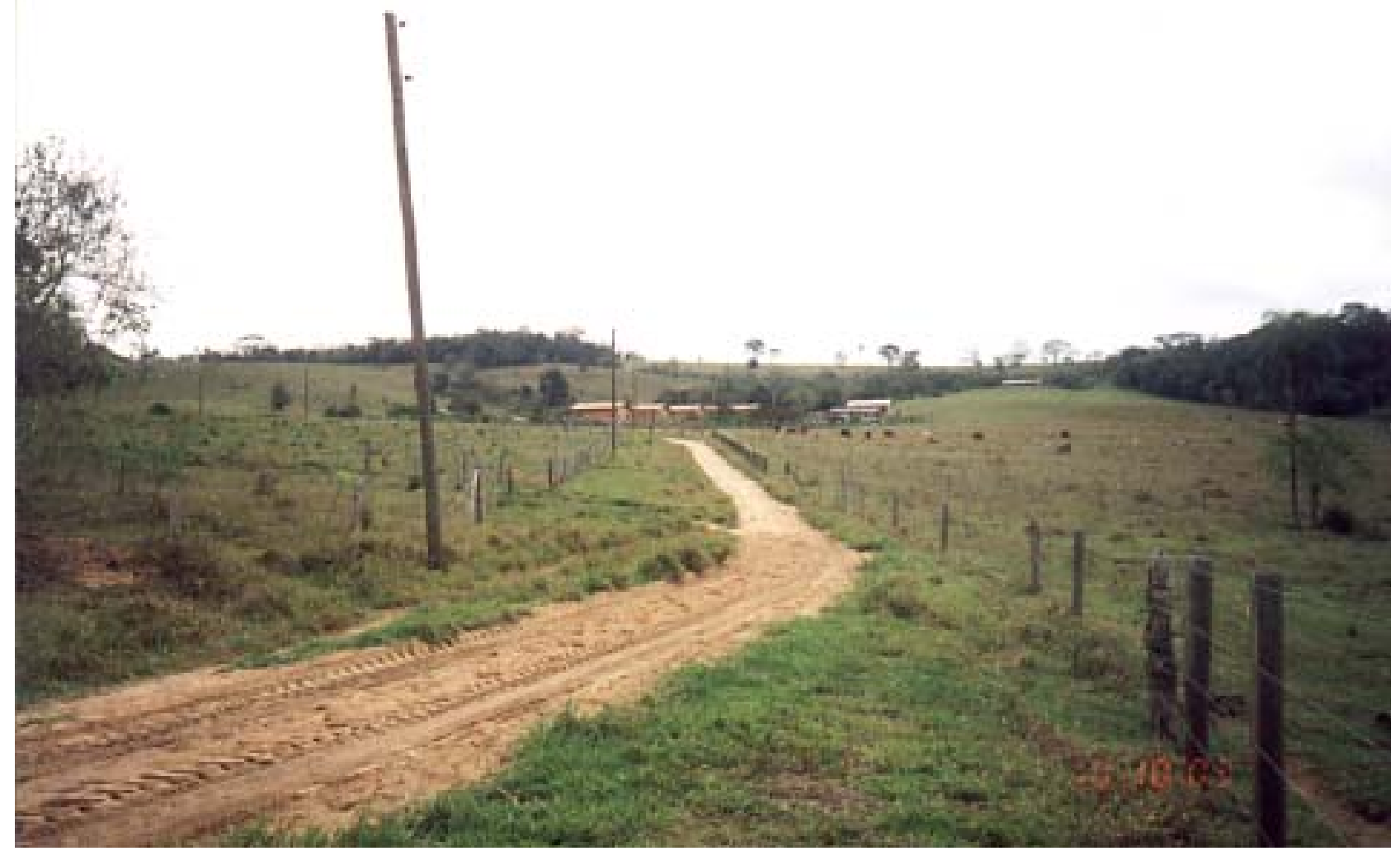

Foto 4

Vista da "mini-agrovila"

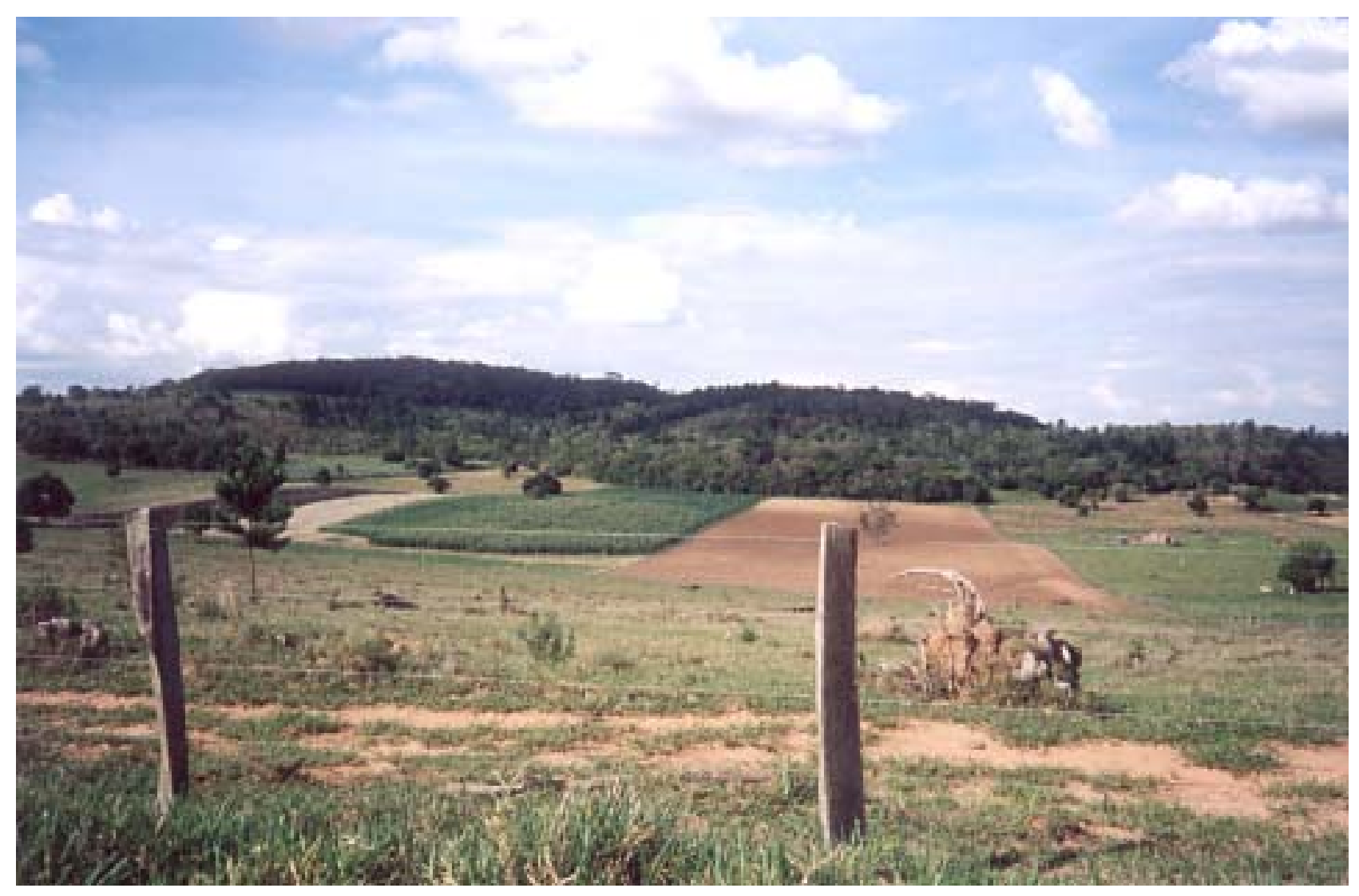

Foto 5

Área de cultivo de milho, cana e feijão 


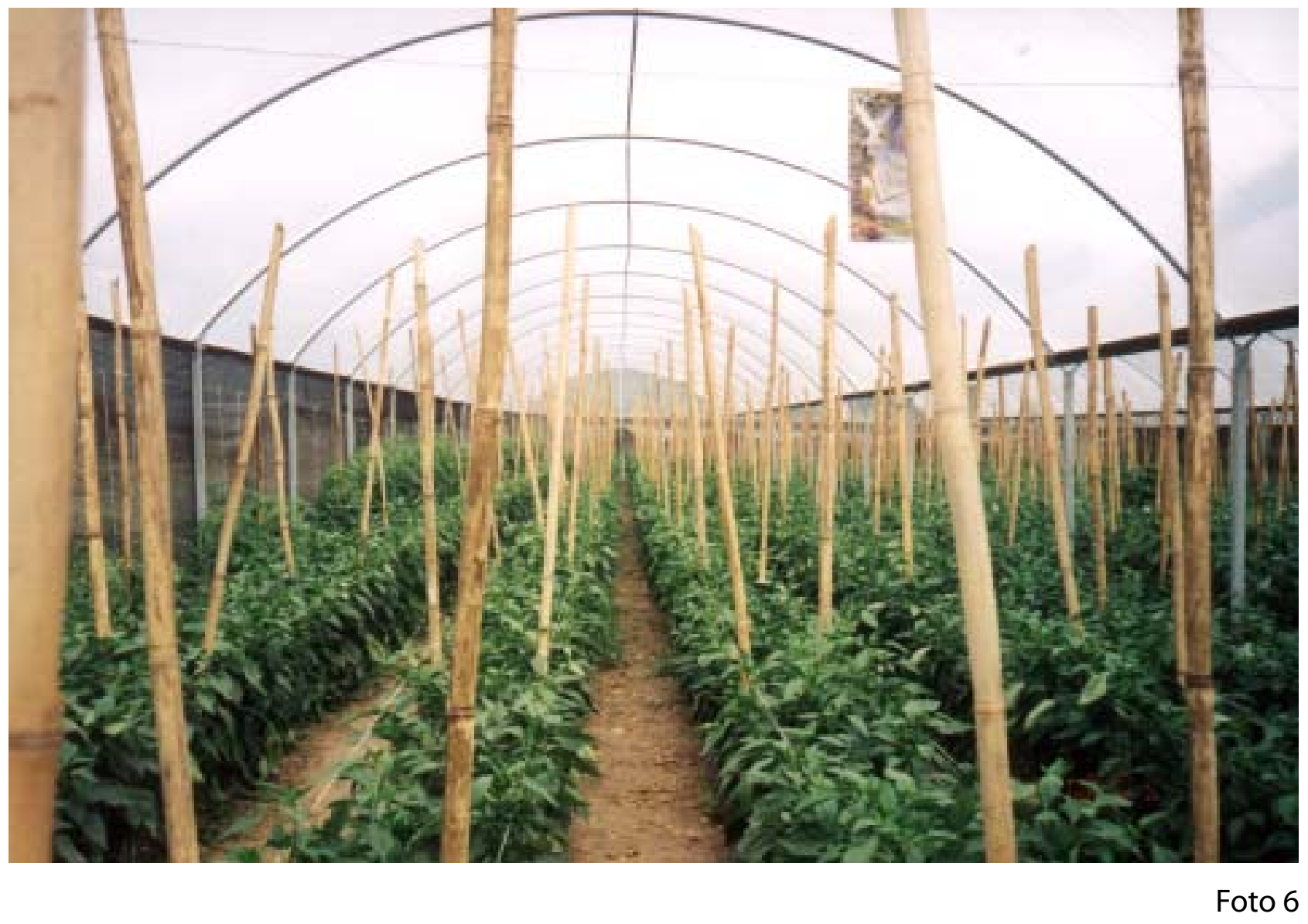

Estufa com pimentões 


\section{Entre campo e dados: as formas de lidar com conflitos sociais}

O MST foi a primeira oportunidade que me apareceи е eи topei.

Ademir $(22 / 11 / 2002)$

O trabalho de campo continua a ser exposto neste capítulo. Dialoga-se com a consulta a fontes secundárias, como documentos oficiais do INCRA, do Poder Judiciário e atas das assembléias do assentamento. Agora o tom é dado pelos principais conflitos internos acompanhados ao longo do período de pesquisa. São três casos a serem descritos e, posteriormente, analisados. A seleção dos casos baseou-se nos seguintes critérios: questões que envolvem, direta ou indiretamente, todos os assentados; ter relação com o Estado de maior ou menor dependência (supondo o Estado como tutor de um assentamento); duração (meses ou ano); ter ocorrido no período do trabalho de campo; grande gasto de trabalho para gerir o conflito (horas de reunião, assembléias, deslocamentos para a cidade, idas a órgãos do Estado, tensões etc.). Os três casos são: 1) desdobramentos na justiça da partilha do dinheiro de fomento; 2) denúncia pública de irregularidades e tentativa de venda de benfeitorias; 3) abandono de lote e venda de benfeitorias. No primeiro caso, temos a gestão do conflito baseada na arbitragem do Estado; no segundo, uma gestão pública e a omissão do Estado e, no último, há o paralelo entre gestão pública e estatal.

Cabe retomar e aprofundar a explicação, vista na Introdução, da distinção entre a gestão pública dos conflitos e a estatal. A gestão estatal dos conflitos não é realizada pelo público envolvido, mas por técnicos operadores da lei e, portanto, distantes do cotidiano gerador do conflito. Além disso, o controle social exercido pelas leis baseia-se em distinções sociais, conforme estabelecido pela teoria de Black (1998).

A gestão pública dos conflitos diz respeito ao controle social e à apropriação do espaço exercido pela população de um dado local, no caso um assentamento de reforma agrária. É este movimento que transforma o espaço em território, no sentido definido por Raffestin (1993). Longe de negar os poderes estatais, essa forma de gestão está em diálogo com eles, mas não se limita a referendá-los e sim a constituir um possível pluralismo 
jurídico ${ }^{1}$. É um caminho para a emancipação do assentamento, no sentido de se ganhar autonomia em relação à tutela estatal, mas não no de livrar o Estado de suas responsabilidades perante a uma política de reforma agrária ${ }^{2}$. De modo geral, a gestão pública pode ser vista como uma "gestão democrática", desde que se assuma uma concepção de democracia como a estabelecida por Quijano (2002), conforme visto na Introdução e, principalmente, no capítulo dois. "A democracia requer um contexto no qual o sistema de autoridade apóie a reprodução de um sistema de controle democrático da autoridade" (QUIJANO, 2002: 511-2).

Com base na teoria do controle social de Black (1998), é possível classificar a formas de gestão de conflitos sociais. O autor caracteriza cinco formas elementares de gestão do conflito: auto defesa ("self help"); evitar (“avoidance”); negociação ("negotiation"); acordo ("settlement"), e, tolerância ("toleration"). A auto defesa é a forma de lidar com a contenda através de uma agressão unilateral, por exemplo, a vingança; o evitar é o rompimento de interação social; a negociação é a decisão em comum; o acordo é a intervenção de uma terceira parte não partidária, e, a tolerância é a opção pela inação diante de um conflito. Nos casos tratados aqui há intervenção do Estado, conforme a condição de assentamento de reforma agrária, portanto, são "acordos”. No entanto, há também uma margem de "negociação" entre os moradores, que é o ponto relevante para a segunda hipótese desta tese: a gestão pública dos conflitos internos referentes à vida coletiva. Sem contar que, como enfatiza o autor, a tolerância está sempre presente, mas nem sempre reconhecida.

Black elaborou uma teoria da terceira parte num conflito em que classifica a intervenção de acordo com os papeis de "dar apoio", com graus crescentes de partidarismo, ou de "fazer acordo", com graus crescentes de autoritarismo. Assim, coloca o papel do “juiz" como tendo alto grau de autoritarismo devido a sua distância em relação ao caso. No terceiro caso analisado, o funcionário do INCRA pode ser classificado como um "árbitro", que teria um grau de autoritarismo a menos do que juiz.

\footnotetext{
${ }^{1}$ Sobre pluralismo jurídico, ver Justo (2002: 152-167).

2 Quando o Estado coloca propostas de "emancipar" os assentamentos de reforma agrária para se isentar de responsabilidades como políticas de crédito, de acompanhamento técnico e de implementação de infraestrutura, concorda-se com o posicionamento da Confederação das Cooperativas de Reforma Agrária do Brasil Ltda (CONCRAB, 1998), órgão do MST, de negar tal emancipação. Porém, há uma luta maior que é a população assentada se apropriar da fração de território e não ficar sob a tutelada pelo Estado.
} 


\section{Três formas de lidar com o conflito}

\section{$O$ “código do sertão” frente à Justiça}

O primeiro caso trata de um conflito em que foi acionada a arbitragem estatal. Já foi exposto ao longo deste texto, mas vamos remontá-lo. Em 18/12/1998, foi assinado pelo governo federal o projeto de créditos de fomento e de alimentação ${ }^{3}$. Havia 63 famílias acampadas naquele momento, que reivindicavam o assentamento da totalidade. Mas, os técnicos do INCRA haviam verificado, inicialmente, a capacidade de assentar 41 famílias, por causa da baixa fertilidade do solo e da localização afastada da fazenda o lote mínimo deveria ter 12 ha. Portanto, em 23/11/1998, o órgão federal homologou 41 famílias aptas para serem assentadas imediatamente e os demais estariam em lista de espera. Os critérios utilizados pelo INCRA para assentar uma família na época eram: 1) preenchimento de formulário com os dados de cada candidato (geralmente o chefe da família); 2) verificação de antecedentes: na polícia e na Justiça, na junta comercial e no INSS; 3) faz-se uma pontuação de cada candidato em que se dá uma nota de acordo com tamanho da família, força de trabalho da família, idade do candidato, tempo de atividade agrícola, moradia no município, tempo de residência, distância da moradia, renda anual familiar e associativismo; 4) entrevista pessoal (realizada em 22 e 23/11/1998); 5) votação por uma comissão. Esta comissão é composta por: prefeito, presidente da câmara municipal, presidente do Sindicato dos Trabalhadores Rurais (STR) municipal, presidente do sindicato patronal, e por um representante das famílias acampadas, e, com base no relato dos itens 3 e 4, vota em cada um dos nomes se "permanece" ou "exclui" do projeto de assentamento. Quatro pessoas foram excluídas, mas os coordenadores do pré-assentamento entraram com recurso junto ao INCRA, em 28/10/1998, que foi deferido e os quatro voltaram para a lista de espera.

Em assembléia do projeto de assentamento de 14/12/1998, os presentes, já sabendo da liberação da verba de fomento, aprovaram a partilha do montante entre todos que participaram da luta mesmo que não fossem assentados ali. Isto é, decidiram que o dinheiro, que viria para 41 famílias, seria dividido entre as 63 e que as 22 excluídas da lista do INCRA devolvessem o dinheiro quando fossem beneficiadas pelo mesmo tipo de

\footnotetext{
${ }^{3}$ Uma vez homologadas as famílias, o INCRA libera os créditos de fomento e de alimentação, que em 1998, consistia em R $\$ 1.425,00$ por família. Esses créditos são a fundo perdido e destinam-se a instalação, como compra de ferramentas, início de horta, alimentação etc.
} 
crédito a fundo perdido ${ }^{4}$. Todos os presentes na assembléia assinaram um termo de compromisso com a decisão de dividir o fomento. Por volta de março do ano seguinte, 1999, ao realizarem novas medições na fazenda os técnicos do INCRA e do Itesp verificaram a possibilidade de assentar mais 6 famílias da lista de espera. Então, em 28/11/2000, 6 famílias que aguardavam no assentamento conseguiram a homologação. Em 22/08/2001, saiu uma lista de desistentes do assentamento e mais um nome da lista de espera pôde ser homologado. Porém, o INCRA havia mudado os critérios para concessão do crédito fomento, deixando de dar em dinheiro e pagando diretamente os fornecedores.

Em 5/06/2002, um dos moradores do assentamento registrou na delegacia do município uma queixa contra quatro ex-coordenadores do assentamento por estelionato ${ }^{5}$. O conteúdo consiste no seguinte: as 22 famílias teriam recebido, no ano de 2001, o crédito de fomento e alimentação, mas os ex-coordenadores não repassaram o dinheiro para os queixosos. Segundo a advogada dos acusados ${ }^{6}$, o delegado ouviu os intimados e mandou para a $1^{\text {a }}$ Vara Criminal. $\mathrm{O}$ caso foi arquivo sem ter denúncia.

Em 20/3/2003, um outro morador, por meio de advogado, abriu uma ação civil de cobrança contra os quatro ex-coordenadores do assentamento. Foi anexado aquele boletim de ocorrência e arrolado como testemunha aquele primeiro morador. Os ex-coordenadores são acusados de terem recebido o dinheiro e de não o repassar aos demais moradores. Vale observar que os autores dessas acusações, com idas e vindas, estão conectados à associação Compartilha, vista no capítulo anterior.

A advogada dos acusados redige uma contestação, em 21/10/2003. Os argumentos são: os acusados não receberam dinheiro das 22 famílias e não há provas desta acusação; os acusados são também credores das 22 famílias que deveriam ser os réus da ação de cobrança; das 22 famílias, somente 6 foram assentadas no local (5 foram para acampamento em Iaras, um mudou-se para assentamento em Sumaré, 6 tem destino desconhecido, 3 foram internados e não chegaram a ser assentados e um faleceu), sendo que os 6 não receberam no forma de dinheiro o crédito de fomento, mas o banco do Brasil pagava diretamente ao vendedor mediante apresentação pelo assentado de nota fiscal da compra. Assim, pede a extinção do processo ou a improcedência da ação.

O juiz de direito julgou improcedente a ação civil, em 31/10/2003, com base nos argumentos de que os acusados também não receberam o dinheiro emprestado às 22

\footnotetext{
${ }^{4}$ Como é liberado $\mathrm{R} \$ 1.425,00$ por família, o montante de fomento para 41 famílias foi de $\mathrm{R} \$ 58.425,00$; dividido entre 63 famílias, cada uma recebeu $\mathrm{R} \$ 930,00$, em números arredondados.

${ }^{5}$ Boletim de Ocorrência No. 392/2002, de 5/06/02.

${ }^{6}$ Entrevista realizada com a advogada em 10/09/04.
} 
famílias, estas famílias não se encontravam mais no assentamento, a finalidade da divisão foi altruísta e que o governo alterou a regra de concessão desse tipo de financiamento ${ }^{7}$.

Ao longo de sete meses em que tramitou esse processo civil houve muita angústia entre os acusados. Uma das pessoas sentia-se, particularmente, humilhada, pois nunca antes adentrara uma porta de delegacia. O aparelho judiciário não faz parte de seu mundo, mesmo que na luta pela terra tenha que, eventualmente, bater em porta de Fórum.

Três dos quatro acusados são vizinhos e amigos, então, reuniram-se para discutir o processo. Cogitaram em, quando encerrasse a ação em que eram acusados, processar o impetrante por calúnia e difamação. Porém, a advogada deles os dissuadiu, devido ao fato de o futuro acusado não ter como pagar por qualquer indenização, nem os custos advocatícios.

Nesse período, moradores ligados ao grupo de Walter colocavam a culpa em Carlos. Diziam que ele errou ao fazer a proposta da divisão do crédito, que deveria ter cobrado para reaver o dinheiro etc. Porém, Carlos mantinha-se seguro diante de uma ação improcedente, pois tudo estava registrado em atas, inclusive o autor do processo também assinou um termo de responsabilidade com a decisão da assembléia em dividir o montante do crédito.

Para o quarto acusado, a Justiça não mostra ser algo exterior a seu mundo, pois ele mesmo abriu um boletim de ocorrência contra um vizinho. Portanto, a arbitragem estatal está em sua rede, mas não na dos outros três acusados. Ao invés de acionar uma comissão do assentamento para tratar do caso, procura a Justiça. É o nó que a que tem acesso.

$$
* * *
$$

Vale mencionar que uma grande tensão vivida na fase de pré-asssentamento devida a não divisão dos lotes foi gerida através da mediação de uma terceira parte externa ao assentamento. Um advogado integrante da Comissão Agrária da Ordem dos Advogados do Brasil (OAB) teve o papel de mediar entre os grupos de assentados uma solução para um impasse criado entre aqueles que queriam morar nos lotes individuais e aqueles que queriam morar em agrovila e trabalhar em áreas coletivas. Consta da ata de assembléia de 9/01/2000, sobre o sorteio dos lotes para as 47 famílias homologadas pelo INCRA, o seguinte: 14 famílias se comprometeram de dividirem seus lotes com outras não homologadas (no momento estavam morando no pré-assentamento 61 famílias) e todos os

\footnotetext{
${ }^{7}$ Processo Civil No. 516/03.
} 
presentes devem se empenhar para assentar as famílias da lista de espera. Na época, foi aprovada a mudança das famílias para os lotes e a construção da agrovila próxima a sede da fazenda; logo, cada família teria seu lote e uma casa na agrovila. Para o advogado ${ }^{8}$, houve nesse caso, uma gestão do conflito sem passar pelo INCRA. A este órgão coube ratificar a decisão da assembléia.

\section{À espera do Estado, a gestão pública}

O segundo caso tem como pivô o mesmo agente do processo civil anteriormente citado, agora envolvido em fazer denúncias de supostas irregularidades no assentamento e de pretender vender as benfeitorias do lote. Os moradores conseguem gerir coletivamente o conflito e o INCRA se omitiu.

Primeiro, o autor da ação civil protocolou uma carta na superintendência regional do INCRA/SP, em 28/01/2003, expondo que, entre outras acusações de irregularidades, não havia gado no assentamento que deveria ter sido comprado com os financiamentos do governo. Em março do mesmo ano, requereu judicialmente reaver sua parcela da divisão do fomento, tratado acima, colocando como testemunha o autor do boletim de ocorrência com a acusação de estelionato. Em setembro, enviou uma carta a um jornal local do município. O jornal publicou uma matéria com o conteúdo da carta em que são feitas denúncias como: obtenção irregular de financiamento, arrendamento de lotes para plantio e pastagem, não produção nos lotes, venda irregular de madeira, venda de lote (Cf. JORNAL NOSSA TERRA, de 13 a 19/09/2003, p. A - 4).

Uma apoiadora do assentamento fez uma mediação entre os assentados e o jornal para garantir um direito de resposta à matéria publicada. Foi formada uma comissão de moradores para tratar do assunto. Os membros da associação Agro União lideraram a comissão e fizeram uma carta para o jornal em que responderam, em nome do assentamento, item por item as acusações, mostrando a produção local. O jornal publicou trechos da carta (Cf. JORNAL NOSSA TERRA, de 27/9 a 3/10/2003, p. A - 4).

O pivô da história tinha a intenção de deixar o lote. Chegou a, sozinho, tentar a vida fora do assentamento e, posteriormente, buscaria mulher e filhos. Acabou voltando. Ele contatou uma das pessoas que arrenda terras no assentamento para que a mesma lhe pagasse pelas benfeitorias do lote para que ele pudesse ir embora com algum dinheiro e não perder o que trabalhou.

\footnotetext{
${ }^{8}$ Declaração dada pelo advogado integrante da Comissão de Questões Agrárias da OAB em entrevista ao pesquisador em 09/09/04.
} 
Houve uma reunião geral do assentamento, em 28/09/03, em que foi comentada a matéria no jornal com a carta denúncia, que causou revolta entre os presentes. Foi aprovada a proposta de elaborar um documento com o relato de atitudes irregulares do denunciante. Tais atitudes não foram especificadas. Uma comissão para encaminhar a decisão foi formada. Em 26/10/03, houve uma reunião geral do assentamento com a presença de representantes de 30 famílias e de um homem interessado em "comprar" (transação irregular) o referido lote. O tom foi de discursos contrários a venda das benfeitorias do lote. Com exceção de uma ou duas pessoas, todos os demais foram contra a venda. Muitos que estavam contra a negociação defendiam que o INCRA deveria possibilitar que o denunciante fosse embora do assentamento; outros tinham pena dos filhos dele e um defendeu que ele ficasse e trabalhasse no lote. Porém, os presentes não se colocavam no poder de decidir, por isso consideraram a reunião como uma consulta à comunidade e não uma assembléia; pois, caberia ao INCRA qualquer medida.

O pivô da ação não estava presente na reunião porque havia deixado temporariamente o assentamento. De todo jeito, ele havia optado por lidar com os conflitos internos através de denúncias externas e não em instâncias públicas do assentamento. Teria maior valor conectar-se a rede do Estado, como o INCRA e o Poder Judiciário, e da mídia ao invés de fortalecer a nodosidade das reuniões/assembléias.

Um dos presentes na reunião aproveitou o momento de acusações mútuas de irregularidades para dizer que não havia uma comunidade no assentamento porque um "quer furar o olho do outro". Ser uma comunidade é uma palavra-chave porque foi usada nesse contexto como denúncia e, em muitas reuniões e assembléia, é invocada como uma realidade dada.

Os moradores ficaram no aguardo do posicionamento de funcionários do INCRA sobre a questão, que nunca houve. Sem a resolução do INCRA, a maioria dos assentados conseguiu, por um tempo, marcar a posição contrária a negociação de lotes ou de benfeitorias. Porém, naquela reunião de outubro alguns moradores foram identificados como potenciais vendedores de lote, como Ivan porque foi um dos únicos a defender a venda do lote.

Como visto no capítulo anterior, no final de 2004, a família de Robério está isolada no assentamento. Para o chefe da família, seus adversários teriam influência sobre as ações do Estado, porque o INCRA e o Itesp lhes favoreceriam. O fato é que os grupos organizados têm melhores acessos aos serviços do Estado do que aqueles que estão 
sozinhos. Como observou Carvalho (1998), as associações servem como mediadoras entre o assentamento e o Estado, pois esta relação não ocorre individualmente.

Por fim vale mencionar que, como o recurso a Justiça tem sido utilizado por Robério, outros moradores querem que os acusados processem-no, para "pôr um basta" numa possível onda de novos processos. Mas, dois ex-coordenadores alegam que ficam com pena dos 8 filhos dele. Segundo o técnico do INCRA, Robério arrendaria o lote e não teria "histórico na agricultura".

\section{O convívio entre arbitragem estatal e reinício de gestão pública}

São enfocadas no terceiro caso as complicações decorrentes da "venda" e abandono do lote 3 por Ivan. Verifica-se a formação de uma comissão como uma instância pública de gestão dos conflitos e/ou irregularidades do assentamento. Mas essa comissão não tem autonomia, pelo contrário, é tutelada pelo Estado. Então, há um convívio entre a arbitragem estatal, a mediação do INCRA, e a gestão pública do assentamento.

Devido a certas irregularidades no assentamento, em março de 2004, um grupo de moradores formou uma comissão para tratar dos casos, com apoio do INCRA. O caso que motivou diretamente o trabalho da comissão foi a venda do lote de Ivan. O histórico é o seguinte. Em 2/4/2004, foi registrado um boletim de ocorrência ${ }^{9}$ em que a companheira de Ivan é vítima de injúria e ele é o autor; consta a seguinte versão dos fatos: em 15/3/04, o autor expulsou a vítima de casa e a chamou de "vagabunda", após o fato, a vítima foi internada em hospital psiquiátrico em Sorocaba por 13 dias. Em 26/04/04 Ivan viaja para Alagoas e deixa em sua casa a filha da moradora vizinha e o companheiro; em 29/04/04, um grupo de moradores do assentamento, com 11 nomes identificados, teria expulsado o casal com a alegação de que Ivan havia abandonado o lote. Naquele mesmo dia, houve uma assembléia dos assentados com a presença de dois representantes do INCRA em que foi criada a comissão específica, com 10 membros, para tratar das irregularidades no assentamento. Ivan quando soube do ocorrido retornou para o assentamento e procurou a polícia para garantir sua entrada no lote. O técnico do INCRA que acompanha o caso contou que Ivan "vendeu" o lote para a moradora vizinha, mas o INCRA a obrigou a desfazer o negócio.

Ocorreram outras duas assembléias extraordinárias sobre o caso em 6 e 12/05/04. Na assembléia de 12/05/05, o representante do INCRA informa que Ivan não tem mais direito ao lote e que a esposa dele não está na lista de espera e, portanto, não pode ficar 
com o lote ${ }^{10}$, este será administrado pela comissão de representantes do assentamento instaurada para acompanhar as irregularidades. Ivan tem que deixar o lote em 19/5 com acompanhamento da comissão. Observa-se na ata que a polícia compareceu à assembléia acompanhada por Ivan e que teria sido chamada também por Zé Roberto, presente na reunião, para averiguar presença de armas ilícitas.

Na assembléia, a esposa de Walter foi excluída da comissão "por agir de má fé", teria defendido interesses pessoais em detrimento do coletivo. Outro membro também foi afastado por não comparecer às reuniões e um terceiro foi confirmado como representante de um semi-coletivo. Com o afastamento da esposa de Walter garantiu-se uma vaga a um representante da associação Compartilha, desde que fosse respeitado o critério de o nome ser aprovado pela comissão. Foi retomado o papel da comissão: levantar os problemas individuais, procurar ajudar, informar o INCRA e tratar como um problema da comissão, ou seja, de todos; deverá realizar assembléias mensais, e, com 50\% mais 1 dos assentos, a assembléia poderá tomar decisões. Devido a existência da comissão, não haverá mais negociações individuais com o INCRA. Este órgão, o Itesp e a comissão irão avaliar todas as liberações de crédito. Ou seja, a comissão terá o papel de representar os assentados perante os órgãos governamentais.

Em 17/5/2004, Ivan entra com “ação de manutenção de posse com pedido liminar" contra um grupo de 11 moradores, quase todos ligados aos grupos das estufas ou à associação Agro União ${ }^{11}$. Segundo os termos da ação, o "pólo passivo" age como tendo todo o poder no assentamento, intimida os "mais fracos com ameaças diversas até conseguirem expulsá-los de seus lotes" e os repassam para seus familiares e que teriam armas de fogo. O advogado requer: liminar de manutenção de posse e medidas para desarmar os moradores do assentamento. Caso não haja contestação em cinco dias, os fatos serão considerados verdadeiros. Quatro sócios da Compartilha são arrolados como testemunhas de Ivan.

Em 18/05/04, os requeridos são intimados judicialmente a não molestar o autor da ação na posse de seu imóvel, sob pena pecuniária. A contestação, de 21/5/2004, argumentou que os requeridos nunca molestaram a posse do autor da ação; a competência para resolver a situação é do INCRA, que para tal mandou representantes para assembléia

\footnotetext{
${ }^{9}$ B. O. No. $365 / 04$.

${ }^{10}$ Como a companheira de Ivan passou a morar em seu lote após o cadastro no INCRA estar somente em nome dele, ela não teria direito ao lote. Esta informação foi dada pelo técnico do INCRA. Vale observar que a Constituição Federal, no Art. 189, parágrafo único, garante que a concessão de uso de imóvel da reforma agrária seja conferida ao homem, ou à mulher, ou a ambos, independentemente do estado civil.
} 
dos assentados, em 12/5/2004; o autor nunca teria trabalhado efetivamente no lote, e, teria transferido ilegalmente a posse do mesmo. A advogada requereu a extinção da ação. $\mathrm{O}$ autor está sendo retirado do lote pelo INCRA. A liminar de manutenção da posse deve ser cassada. O autor não aplicou devidamente os recursos oriundos do governo federal para a produção do lote. Requer: que a ação seja contra o INCRA ao invés dos requeridos e cassação da liminar de manutenção de posse, ou, a improcedência da ação.

Consta daquela peça a seguinte frase: "Ocorre que o requerido não tem perfil de trabalhador do campo. Não quer trabalhar, crescer e progredir, e por não ter interesse em participar, atenta contra a boa fé de quem quer prosperar". Esta frase será trabalhada mais a frente.

Em julho de 2004, é documentado que Ivan adquiriu um imóvel em Maceió/AL e abriu mão de seu lote no assentamento, deixando-o para sua ex-companheira. Ele se mudou para Alagoas e sua ex-esposa ficou no imóvel.

A procuradoria do INCRA manifesta-se e assume a competência do caso. Vai para a instância federal para o órgão reaver a posse do lote e repassá-lo a quem de direito estiver na lista de espera. O setor jurídico do INCRA ficou de dar uma resposta sobre com quem ficaria o lote no dia 16/11/04. Porém, até janeiro de 2005, não havia julgado o caso.

No final de outubro de 2004, três jovens casais acamparam no lote de Ivan com a intenção de garantir que o INCRA repassasse o lote para um deles, que estão na lista de espera. Eles já haviam feito tal ação anteriormente, da primeira vez que Ivan deixou o lote em abril de 2004. As mulheres acampadas foram ameaçadas de agressão física por dois moradores. Algumas pessoas foram socorrer as mulheres e reagiram com violência física. Em 2/11/04, houve uma reunião em que se discutiu os fatos ocorridos e com uma tendência a descaracterizar como trabalhador rural os membros da Compartilha. Essa reunião foi tratada ao final do capítulo quatro. Na figura 13 mapeiam-se os lotes que tem interesse, direto ou indireto, na disputa pela área que era de Ivan: de um lado estão as pessoas ligadas diretamente a Ivan, inclusive aquela que teria "comprado" o lote dele e, de outro, as famílias que desejam que a lista de espera, reconhecida pelo INCRA, seja respeitada.

Por fim, enquanto o INCRA até o momento ainda não oficializou a situação do lote de Ivan, a ação civil impetrada por ele terminou em 16/11/2004. Nesse dia houve uma audiência no Fórum em que uma testemunha disse que não sabia de nada sobre os fatos. Esta testemunha é Walter, que percebe que - mesmo atacando seus opositores - não pode

\footnotetext{
${ }^{11}$ Processo Civil No. 951/04.
} 
mais aparecer como ligado a Ivan e outros. O Juiz julgou de competência do INCRA resolver a ação.

\section{Arrendamento de lotes, um caso a parte}

Os principais arrendatários no assentamento são três indivíduos, dois irmãos e um primo, produtores e comerciantes de melancia desde 1992. Eles são sitiantes vizinhos do local e, como não possuem terra suficiente para plantio, arrendam área na fazenda desde 1997, antes da chegada dos Sem Terra. Possuem trator, caminhão, dinheiro e contato com mão-de-obra volante para as etapas de produção. Com o antigo proprietário, eles cuidavam de todas as etapas de plantio e colheita e ficavam com todo o resultado da venda, o dono ganhava o pasto que crescia após a safra. Com os assentados há três formas de arrendamento: o dono do lote não trabalha, o arrendatário faz tudo e paga até 10\% da venda àquele; os dois lados dividem meio a meio os custos do plantio (inclusive o pagamento de mão-de-obra, caso necessite), o arrendatário faz a colheita, vende e paga uma porcentagem ao dono do lote (esta forma é denominada de parceria); o arrendatário simplesmente paga um aluguel ao arrendador (em torno de R\$400 por alqueire). O primeiro formato é o mais comum e a parceria, o mais raro. A maioria da mão-de-obra volante é contratada entre os assentados, desde o plantio até a colheita, quando geralmente é necessário trazer trabalhador de fora. No plantio, paga-se por dia trabalhado e na colheita, por caminhão carregado. Entre 2003 e 2004, um dos arrendatários plantou em 9 lotes e seus primos em outros; eles só não querem as terras dos lotes nos tocos. Ao contrário daquilo que os assentados e os técnicos do Itesp dizem, os arrendatários consideram a terra ótima, para melancia ${ }^{12}$.

Os arrendatários foram aos poucos conquistando espaço no assentamento. Na época da ocupação da fazenda, eles tinham preconceito contra os Sem Terra, mas logo começaram a os ajudar emprestando o caminhão ou o trator e construíram uma relação de favores. Exemplificando, um morador arrendou uma área de seu lote até 2002; em 2003 ele e o arrendatário dividiram o trabalho meio a meio com este emprestando o tratar e garantindo os insumos, e, em 2004, o morador dominou o cultivo da melancia e plantou sozinho. Portanto, o arrendamento/parceria permite ao assentado acesso a um cultivo comum naquela terra e a uma rede externa ao assentamento, o comércio da fruta. A partir

\footnotetext{
${ }^{12}$ Colhem em média 80 toneladas por alqueire, o que gera em torno de 12 mil reais. O investimento para a produção é de 5 a 6 mil reais por alqueire para preparação da terra (calcário e máquina), semente, insumos, defensivos e mão-de-obra. O ciclo da melancia é de 100 a 120 dias, com plantação de julho a setembro com auge em agosto.
} 
de 2004, com a comissão de assentados para averiguar as irregularidades, os arrendatários querem garantir algum espaço. A comissão permitiu ao assentado que já tivesse arado a terra para arrendamento ou parceria concluir a colheita até o final do ano, mas no ano seguinte não poderá arrendar.

\section{Poder e território - tessituras, nós e redes}

Há uma mudança de tessitura, nós e redes no assentamento. A maioria das famílias, em torno de 28, está organizada, conectada a redes e sofre acusações de outros. O que se constata ao final do trabalho de campo é que a tolerância daquela maioria para com seus detratores chegou ao limite. Dentre essas famílias há o interesse em ficar com o lote de Ivan para assentar os filhos casados. Esse lote virou objeto de disputa. Um grupo de quatro famílias estaria envolvido em não deixar que membros daquela maioria ficassem com o lote de Ivan, pois houve a negociação entre este e sua vizinha. Além disso, três vizinhos pressionaram para que o lote não fosse para as mãos dos jovens acampados.

Pelo observado nesse último caso, o morador teve necessidade de sair do lote, seja por motivos pessoais, seja por falta de condições de trabalhar plenamente o lote (pouca mão-de-obra, sem maquinário, não aplicação devida dos créditos federais e, principalmente, por estar numa rede fraca). E, há o interesse de outros moradores em ampliar sua área cultivada, devido ao crescimento da família ${ }^{13}$. Portanto, lotes com áreas iguais de 12 ha podem ser muito ou pouco dependendo do tamanho da família. Logo, a divisão igualitária, neste caso, não representou justiça porque não incorporou a noção de necessidades diferentes, como nos ensinou Marx (1961).

Lotes vagos são trunfos e, por isso, um jogo de forças incide sobre eles. Chayanov (1974) já havia demonstrado a relação do aumento da família com o da área cultivada. Essa é uma longa questão no universo da literatura sobre camponês, que não cabe aqui aprofundar. Aponta-se somente que os trabalhos de Carvalho (1999) e Miranda (2003) tratam da recente questão nos assentamentos de reforma agrária: como ficam os jovens e futuros herdeiros dos lotes e a falta de política voltada para esta questão.

Houve uma tensão acentuada na fase de pré-assentamento em relação a se morar, ou não, em agrovila e trabalhar coletivamente em áreas comuns. Isso foi negociado com o

${ }^{13}$ Conforme análise de Miranda (2003) os conflitos jurídicos gerados pela venda ou transferência irregular de lote de reforma agrária revelam a falta de uma política - tanto do Estado quanto do MST - no sentido de encontrar formas de assentar os filhos adultos de assentados. 
INCRA, que a princípio não tem um padrão pré-estabelecido sobre implantar lotes individuais, ou não. A decisão de lotes individuais não foi do Estado e sim resultado do jogo de forças entre os futuros moradores; o INCRA pode apenas ter influenciado. Os moradores souberam tratar a questão da divisão dos lotes, após forte tensão, através da mediação de um advogado da Comissão Agrária da OAB.

Após esses comentários amplos, cabe afinar as cordas dos casos anteriores para ouvir o que soam. No primeiro, de busca do Estado como instância de justiça, há tanto o comportamento do código moral que nega a justiça estatal quanto a luta pelo direito a usar a lei. A voz de uma das acusadas no processo ao se sentir envergonhada por ter de ir ao Fórum ressoa como uma reedição do "código do sertão", analisado por Franco (1969), mas sem a legitimação da violência física como forma de lidar com os conflitos. $\mathrm{O}$ fato descrito no capítulo quatro de que um dos interlocutores me pedira para não revelar a existência de processos judiciais num assentamento do MST porque seria ruim para a imagem do Movimento também manifesta uma fuga do domínio do Estado de direito. Porém, o código do sertão não é assumido em sua plenitude porque aqueles dois moradores não defendem a violência como algo constitutivo das relações sociais. Qual é o significado de se querer negar a procura pela instância estatal de gestão de conflito? Talvez seja resultado de uma visão sobre o mundo da lei como "terra de ninguém", a impessoalidade de lei como insegurança, como muitos estudiosos de nossa cultura mostraram. Mas, pode manifestar também uma vontade de autonomia em relação à tutela do Estado.

A trajetória das lutas camponesas por direitos abre-se em muitas veredas. Por um lado, um marco dessa luta está nas Ligas Camponesas, entre a segunda metade de década de 1950 e início dos anos 1960. A luta de Julião, um dos expoentes das Ligas, baseava-se no uso do código civil como instrumento de defesa dos direitos dos trabalhadores rurais, que têm, segundo ele, uma forte orientação legalista. Por outro lado, a luta por direitos legais e pela aplicação de leis se fortalece com o Estatuto do Trabalhador Rural, no início dos anos 1960.

A luta por direitos e pela aplicação das leis trabalhistas aparece tanto no camponês morador de engenhos da zona da mata pernambucana, dos anos 1970, que foi expulso para a cidade (SIGAUD, 1979), quanto nas lutas sindicais e judiciais contra a expulsão no Vale do Jequitinhonha/MG, na virada dos anos 1970 para os 80 (MOURA, 1988). Há também casos em que a luta por Justiça ocorre paralelamente com formas de justiça camponesa, como na zona da mata paraibana na virada dos anos 1980 (JUSTO, 2002). 
Decorre que tanto repelir o apelo à Justiça quanto buscar as leis são características do campesinato brasileiro. Neste sentido, não se pode ver nas ações de procurar a Justiça algo que desabonaria a conduta do trabalhador rural. Além dos três casos, verificou-se no assentamento uma dinâmica entre alguns vizinhos de se recorrer a registrar boletins de ocorrência na delegacia por causa de brigas e/ou problemas de gados que rompe cercas. De certa forma, quem está sozinho, fora dos grupos, utiliza-se mais dos recursos estatais como forma de mostrar conexão a uma rede, que nem sempre é o meio mais adequado para gerir certos conflitos. Isto demonstra a dificuldade de constituição de um espaço público de gestão do assentamento.

$\mathrm{O}$ recurso à polícia e ao Poder Judiciário impregnou tanto o assentamento que quando as pessoas estão sofrendo uma ação judicial já pensam em processar aquele que as processou. É uma forma de revanche, que teoricamente a Justiça poria um fim. No primeiro caso analisado, a advogada dos acusados os dissuadiu a processarem o autor da ação. Nota-se que o recurso à Justiça aproxima-se a ciclos de vingança, que repõem o mesmo tipo de conflito, sem dar margem para o surgimento de novos tipos de conflito.

No segundo caso, os moradores amparam-se nas instâncias públicas do assentamento ao fazerem reuniões e assembléias e criarem comissões. Porém, esse espaço público é recriado a partir do conflito. Ou seja, não há uma prática de gestão pública do assentamento, ela ocorre a reboque do conflito do momento. A situação de assentado, por definição, é de tutela estatal exercida pelo INCRA e baseada num contrato jurídico. No caso tratado, os moradores enquanto esperavam a arbitragem do INCRA conseguiram mostrar força ao não aceitarem a venda de benfeitorias e repasse do lote a uma pessoa de fora do assentamento. O INCRA absteve-se desta questão, que como bom tutor sabe que o tutelado anda sozinho de maneira insegura. Os moradores acreditam que é dever do INCRA intervir para regularizar a situação, mas não ficam parados esperando.

No transcorrer do caso, foi muito ouvido que as pessoas sentem pena em relação aos filhos de Robério. É um paradoxo, pois este morador expressou sua vontade de deixar o local atacando todo o assentamento, a maioria dos assentados não queria mais sua presença ali, mas o toleram por pena dos filhos. Robério disse que alguns moradores queriam retirar a guarda dos seus filhos; é assim que ele viu o "dó”. Quer dizer, as relações sociais e conflitos estão envoltos em ambigüidades e ambivalências, que merecem ser tratados no próximo capítulo.

Como já mencionado, Carvalho (1998) mostra que as associações de produção têm um papel na gestão política do assentamento. No assentamento aqui estudado, os membros 
da associação Agro União estão entre os mais atuantes para tratar das irregularidades. Para se ter idéia, cada morador tem um contrato individual com o INCRA em que consta uma página com as seguintes proibições no lote: a transferência sem anuência do INCRA, o parcelamento, o arrendamento, a não-exploração, efetuar compra sem estar na lista de espera, o abandono, a comercialização de bebida alcoólica ou ter estabelecimento comercial, manter salão ou mesa de jogos com fins lucrativos, a construção de residência com finalidade de lazer transformando a área em condomínio, manter atividade pesqueira com finalidade lucrativa. Logo, todos estão cientes do que é, ou não, irregular. Porém, fazendo parte de um grupo e/ou associação ajuda a não se cair na irregularidade.

No terceiro caso, a comissão formou-se, em 29/04/04, como uma instância pública independente para tratar de irregularidades de um modo geral, não mais a reboque de conflitos específicos. Nela há vagas para representantes das duas associações e do grupo das estufas e é majoritariamente composta por membros do grupo das estufas e da associação Agro União. O INCRA, que incentivou a formação da comissão, resolveu parcialmente o caso porque fez com que a venda irregular do lote fosse desfeita, mas demora em reaver o lote. Assim, a comissão tem seu poder limitado pelas ações do Estado. A função da comissão é verificar as irregularidades dos lotes, tratar como problema de todos e não individual, comunicar o caso ao INCRA e mediar entre governo e parceleiros a liberação de créditos. Uma das principais irregularidades é o arrendamento de lotes. O técnico agrônomo responsável pelo assentamento informou que há uma lista de cinco lotes que estão sendo averiguados por causa de possíveis arrendamentos, além da situação do lote de Ivan. Ao ter o papel de intermediar a liberação de créditos federais, a comissão acumula poder e influência. No entanto, ainda há uma dinâmica no assentamento em que algumas pessoas sentem-se excluídas de uma instância coletiva de decisão. Há quem julgue que os membros da comissão teriam maior facilidade de acesso aos serviços técnicos e de crédito do Estado. Quanto ao arrendamento de lotes, na comissão há membros que fizeram parcerias e não pretendem fazer mais porque estão contra quem só arrenda. Antes havia tolerância (e certa cumplicidade) com quem só arrenda e agora esta tolerância chegou ao fim.

Vale ressaltar que, apesar das dificuldades de formação, essa comissão constitui-se como uma possibilidade de gestão pública dos conflitos internos referentes à vida coletiva, conforme formulado na segunda hipótese deste trabalho. Porém, uma parcela dos moradores carece de vontade de aprender a lidar com os conflitos de maneira pública. Portanto, a comissão precisa ser uma instância que inclua a todos de maneira educativa, se 
quiser perdurar. Caso contrário, ela acirrará as desigualdades existentes entre assentados. Ela tem potencial para encontrar os meios de aprendizado para a gestão coletiva dos conflitos.

O pesquisador não teve nenhum papel na formação dessa comissão, apenas chamou a atenção dos membros, numa reunião em 2/11/2004, para a possibilidade de estar excluindo aquelas pessoas associadas a Compartilha. A esta couberam os laços mais fracos das redes que atravessam o assentamento. Posto isso, consideram-se respondidas a segunda hipótese desta tese, sobre as condições de realização de uma gestão pública dos conflitos internos referentes à vida coletiva, e as perguntas decorrentes sobre as formas de realização e as limitações dessa gestão e sobre o papel do pesquisador no processo.

A questão do ethos camponês reverbera mais uma vez, agora relacionando-se com a necessidade de um aprendizado democrático para a consolidação de uma esfera pública no assentamento. A referida comissão é liderada pelos moradores da associação Agro União e pelo grupo das estufas, os mais influentes e, visivelmente, em melhores condições materiais. As pessoas ligadas à associação Compartilha aparecem como "ruídos" para a maioria; esta nega atributos de trabalhador rural aos membros da Compartilha (“Exculhidos”), estes, por sua vez, não reconhecem a comissão como um espaço de todos. Certos membros da comissão taxam alguns moradores de "criminosos" e os relacionam ao grupo de Walter, este também diz que há "criminosos" no assentamento.

Um dos incidentes presenciados nos conflitos sociais internos do assentamento em que houve violência física envolvia, de um lado, pessoas ligadas à associação Compartilha e, de outro, as ligadas à associação Agro União e ao grupo das estufas. O revide à ameaça foi um típico caso de reação à violação de certos princípios morais. Isto é, foi uma situação de manifestação da campesinidade através do critério de "justiça camponesa” (Cf. JUSTO, 2002: 161). O que interessa desse fato, que não cabe aqui aprofundar, é ressaltar que há uma convivência entre formas de justiça estatal e não-estatal.

Neste sentido, há um caminho percorrido na fase de acampamentos e outro a ser trilhado no assentamento. Nos acampamentos, as pessoas estão sujeitas à disciplina da organização do MST. Essa disciplina, que - por exemplo - proíbe uso de álcool ou drogas, permite que o conjunto de acampados, através da coordenação, expulse os casos extremos de infração. No assentamento, como o domínio da terra pertence ao Estado tutor, os moradores não têm o direito de expulsar alguém, podem apenas indicar tal necessidade ao INCRA. Atualmente, alguns moradores ressentem-se de não ter mais a disciplina do acampamento. Porém, esta referida disciplina não se preocupa com a garantia de certos 
direitos universais de defesa. O passo a ser dado no assentamento é a construção conjunta de uma concepção de direitos que seja multicultural, como a defendida por Santos (1997), como resultado da fricção entre as culturas dos camponeses de quase todo o Brasil que se encontram no assentamento e os direitos universais do Estado moderno.

Vale retomar, por fim, algumas reflexões de Santos (2000, 2002). No busca de ações pelo mundo que possam reinventar a emancipação, Santos chama a atenção para que o pesquisador reflita sobre seu papel nas comunidades que estuda. Ou seja, a ciência não deve ser feita sem auto-reflexão (SANTOS, 2000). Cabe voltar aos relatos de campo para refletir.

Na reunião dos assentados de 26/10/03, a pauta era discutir e se posicionar diante do interesse de Robério em vender as benfeitorias e deixar o lote; porém, outras questões foram tratadas. Vladimir, por exemplo, colocou para Zé Roberto que já o havia defendido perante o INCRA por arrendar o lote e que não o faria mais. Falou para Ivan que ele seria o próximo a querer "vender" o lote. Portanto, já estavam anunciados os conflitos que se desenvolveriam no ano seguinte. Outro aspecto da reunião foi que alguns que tinham falas mais exaltadas e melhor capacidade de argumentação linear, estabelecendo uma sequiência e chegando a conclusões, tomavam mais tempo do que aqueles de voz calma e argumentação mais circular, que volta sempre ao mesmo ponto sem concluir. $\mathrm{O}$ pesquisador estava presente na reunião como observador e não lhe foi solicitada a palavra. A questão é: eu percebia que poderiam ter alguns mecanismos democráticos de reunião como, por exemplo, garantir a todos tempo igual de fala ou de restringir as discussões à pauta. Porém, não seria democrática a intervenção do pesquisador porque o estudo não havia sido solicitado pelos assentados e nem atendia aos seus interesses imediatos. Portanto, considerei que não haveria uma autoridade legítima em minhas possíveis contribuições. Mesmo sabendo que elementos externos podem ser necessários para avançar a construção do espaço público no assentamento, a intervenção deve ser construída com os moradores; afinal, não há porque dizer que o universo do pesquisador é de esfera pública plena e democrática e o dos assentados, não. A vivência de relações horizontais e democráticas é algo a ser realizado tanto para os pesquisadores quanto para os pesquisados. Isso posto, é possível afirmar que a concepção de que num assentamento de reforma agrária predominam relações autoritárias e que o aprendizado da democracia depende de intervenção externa (D’INCAO e ROY, 1995) baseia-se numa visão de que o mundo do outro é assimétrico ao do pesquisador. 
Por fim, vale retomar a tese de Santos (2002) sobre radicalização da democracia participativa e da democracia econômica como duas faces da mesma moeda porque responde ao conjunto de questões deste capítulo: a gestão de conflitos, a constituição de um espaço público (democrático) e a superação da distinção entre gestão política e econômica.

Uma das características emancipatórias das alternativas de produção não capitalista consiste no seu potencial para substituir a autocracia típica da produção capitalista - isto é, a autoridade vertical que emana do 'patrão' ou do manager - pela democracia participativa no interior das unidades de produção. Em outras palavras, o objetivo é estender o campo de ação da democracia do campo político para o econômico e apagar, desta forma, a separação artificial entre política e economia que o capitalismo e a economia liberal estabeleceram. Essa ampliação, todavia, implica mais do que uma alteração quantitativa. O efeito essencial da expansão do princípio democrático é a criação de possibilidades de transformação qualitativa de democracia na direção de uma democracia participativa. É este tipo de democracia que está subjacente às alternativas radicais à política liberal e ao capitalismo. (...)

Os estudos sobre o MST abrem toda uma série de perguntas sobre a relação entre as alternativas econômicas e democracia interna. Neste sentido, este livro [Produzir para Viver] serve para iniciar um debate que pode ser frutífero em relação à evolução futura do movimento, cujas realizações são reconhecidas tanto pelos autores dos capítulos quanto por movimentos e organizações de todo o mundo. $\mathrm{O}$ debate refere-se à foram pela qual as realizações do MST foram ou não acompanhadas pela criação de uma estrutura interna democrática e aberta (SANTOS, 2002: 69-70).

O autor refere-se ao debate presente nos textos de Navarro (2002) e Carvalho (2002) e às contribuições das análises de Singer (2002a) e Lopes (2002). Estes quatro textos foram trabalhados no capítulo três da presente tese. Com base em autores como esse e outros, no próximo capítulo será feita uma análise relacionando os capítulos teóricos com os empíricos. 
Famílias envolvidas na disputa de lote

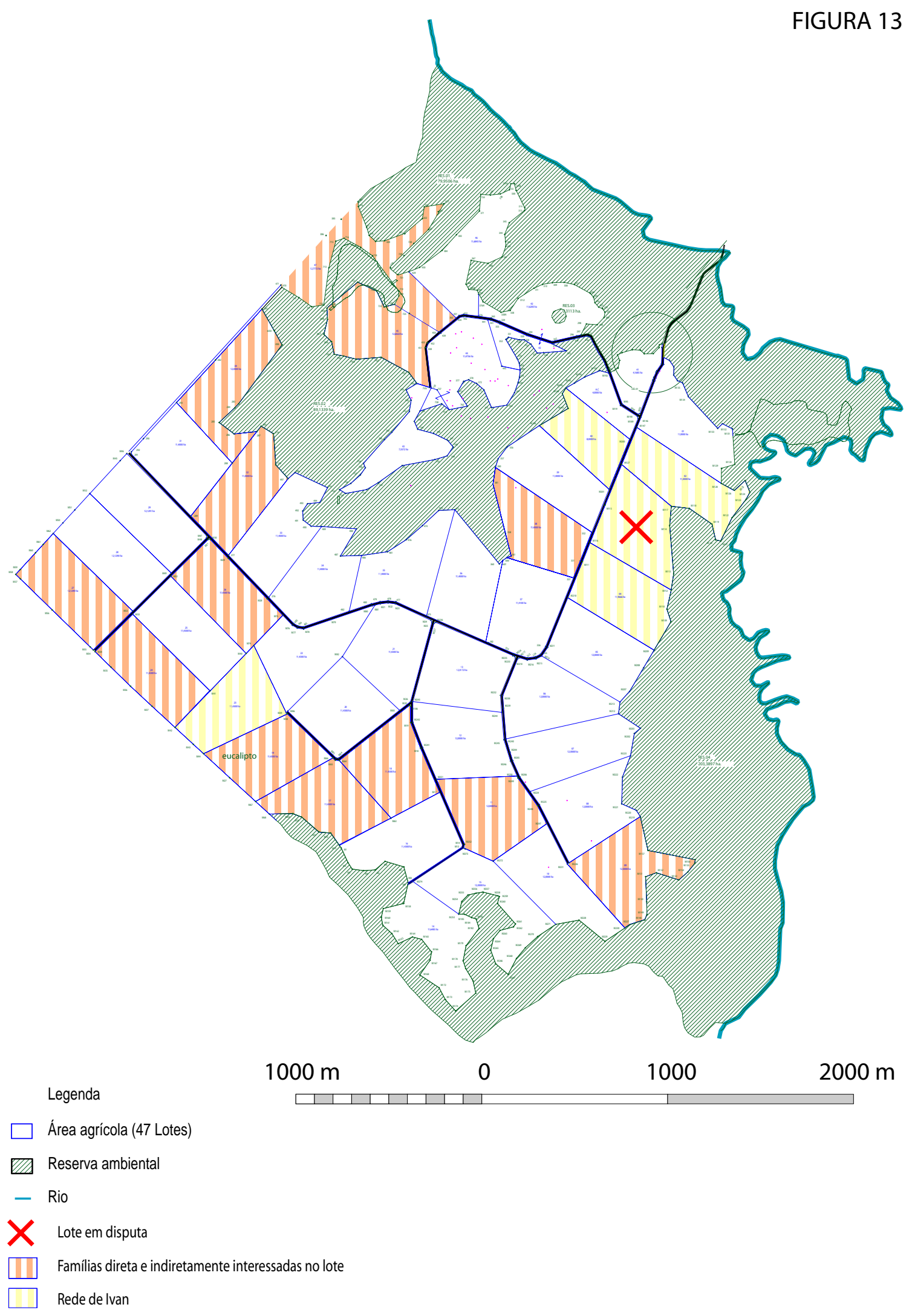




\section{Parte 3 - a teoria e a empiria}




\title{
Teoria e empiria em ressonância
}

\author{
O combate é de todas as coisas pai, \\ de todas as coisas rei, e uns ele \\ revelou deuses, outros, homens; de uns \\ fez escravos, de outros livres. \\ Heráclito
}

\section{Conflito, democracia e justiça social}

Há neste capítulo a análise dos dados empíricos, expostos e interpretados na segunda parte desta tese, ao ritmo das referências teóricas apresentadas na Introdução e na primeira parte. Vale destacar que privilegiar o conflito social é concebê-lo como motor da vida em sociedade e não como algo voltado para a anomia. Ou seja, os conflitos sociais foram buscados porque eles constituem as relações sociais, sem eles não haveria sociabilidade. Essa perspectiva é chamada, num registro amplo, de tradição dos conflitos. Nessa perspectiva, os trabalhos de geografia seguidos nesta tese também privilegiam os conflitos sociais, como os trabalhos de David Harvey, Claude Raffestin, Yves Lacoste e, no Brasil, Ariovaldo de Oliveira e Regina Sader, entre muitos outros. Conflitos, política e democracia andam juntos: para Jaques Rancière (1994), a política é dissenso e o consenso acaba com ela e coloca a polícia em seu lugar, e, para Francisco de Oliveira (1991), o método democrático consiste em construir regras pelo conflito, pelo reconhecimento da alteridade.

Dada essa premissa dos conflitos, analisa-se um assentamento de reforma agrária como local de potencial realização de justiça social. Pois, nesse local é possível emergir o “desemprego criador", conforme definição de Illich, e a economia solidária de Singer. Assumir que os assentados, com suas diferentes trajetórias e experiências pessoais, levam para os assentamentos um conjunto de conhecimentos não escolarizados que ajuda a erguer o local é reconhecer o processo como justiça social. Para Illich, a justiça social é a união da justiça distributiva, como igualdade de acesso a bens, com a participativa, como igualdade na criação de valores de uso. Essa concepção está em sintonia com a máxima de Marx: “de cada qual, segundo sua capacidade; a cada qual, segundo suas necessidades" (MARX, 1961: 217). A economia solidária será retomada logo a seguir. 
A questão agrária no Brasil permanece em aberto e é recolocada na discussão sobre a relação entre a produção camponesa e os caminhos de construção do socialismo (Cf. STEDILE, 1994). Já é uma interpretação clássica de que o modo de produção capitalista se expandiu para o campo sem precisar alterar a concentração fundiária (Cf. OLIVEIRA, 2002). Diante da questão, opta-se pelo seguinte enfoque analítico: a economia solidária como socialismo dentro do modo de produção capitalista, segundo elaboração de Singer (2002b). Este autor não compartilha de uma perspectiva histórica em que um modo de produção esgota-se totalmente para começar um novo, mas coloca a convivência entre modos de produção distintos. Sendo assim, a economia solidária é um outro modo de produção que coexiste com o capitalista, mesmo sendo contrário a este, e tem possibilidade de vir a ser hegemônico (SINGER, 2004). A economia solidária é um modo de produção e também um modo de vida porque implica uma sociabilidade mais democrática. No entanto, para a organização do MST, “a cooperação agrícola como organização econômica está inserida no sistema econômico vigente na sociedade, ou seja, apesar de ser uma forma socialmente avançada de organizar a produção na agricultura, por si só não derrotará o capitalismo" (MST, Produção: assentamentos e cooperação agrícola, 1991, apud Souza, 1999: 110). Nessa contraposição entre Singer e organização do MST, o posicionamento defendido nesta tese é que, independentemente de o mercado ser organizado por relações capitalistas, os assentamentos podem consolidar a economia solidária e se relacionar com o mercado. Há milhões de pequenas e médias propriedades rurais que, potencialmente, podem se inserir na rede de relações solidárias e que possuem relações com o mercado sem ser capitalistas, sendo camponesas. Portanto, o caminho para uma sociedade socialista não depende exclusivamente da tomada do Poder pela classe trabalhadora da cidade e do campo, como nas concepções de Stedile (1994), por exemplo ${ }^{1}$. Cabe, principalmente, constituir e fortalecer a economia solidária nos assentamentos e colocá-los na rede desse outro modo de produção. Aliás, a posição da economia solidária e da gestão democrática está presente no MST, como analisa Ferreira (2000).

Ao se tratar da justiça social, a dimensão da construção do conhecimento e da relação entre os conhecimentos científico e camponês também deve estar presente. A concepção de rede de Latour propicia que se nivele o conhecimento científico e os demais conhecimentos, pois vale o princípio de simetria. $O$ que diferencia as formas de conhecimentos é o tamanho das redes tecidas. Assim, a valorização feita por Illich do

\footnotetext{
${ }^{1}$ Ver as pertinentes críticas de Navarro (2002) às posições políticas não-democráticas da direção do MST. Porém, essas posições não impregnaram as bases do Movimento.
} 
conhecimento do desempregado - daquele que não tem uma profissão - ganha força. Para Latour, a justiça passa pelo conhecimento, no sentido de que o científico não pode estar acima dos demais tipos de conhecimento, ou seja, há uma simetria entre os saberes. Apesar de não se estar pesquisando o conhecimento produzido pelos camponeses, em que o método de Latour seria adequado, segue-se o registro epistemológico e de justiça proposto pelo autor: a ciência tece redes e é simétrica aos demais conhecimentos.

\section{Modernidade, campesinato e ciência: território e rede}

Como visto no primeiro capítulo, o pensamento moderno está situado numa tensão entre pensamento conservador e hierarquizante versus utopia horizontalizante e emancipadora. Atentar para práticas emancipatórias e não para as regulatórias, conforme colocado por Santos (2000 e 2002), é o registro em que se insere a discussão sobre modernidade nesta tese. Acredita-se que nos estudos locais é possível encontrar elementos que sejam tanto emancipatórios do grupo estudado, quanto potencialmente universalizáveis.

Se as concepções sobre camponês e morador de rua do pensamento moderno estão envoltas em ambigüidades e ambivalências, cabe ao pesquisador questionar, analisar e se posicionar. Conceitualmente, a posição adotada é que o camponês é recriado pelo modo de produção capitalista ${ }^{2}$. Logo, ele não é só a ordem moral opositora a este modo de produção, é também produto de um aspecto da modernidade. O campesinato, então, possui características que são permanentes e outras que são mutáveis, assim como ele recria valores tradicionais, pode incorporar novos registros da modernidade. Tomando como referência a análise feita por Augé (1999) sobre o sentido dos outros, podem ser observadas uma ambivalência nos camponeses, ser e não ser o Outro da modernidade, e uma ambigüidade, não ser moderno nem tradicional. Segundo o autor, a ambigüidade como instrumento de análise do ritual - não perdura sem que surja um terceiro termo. No caso aqui tratado, o terceiro termo é a inserção de ex-moradores de rua em assentamentos, por meio do ritual de ocupar, acampar e conseguir a desapropriação. A questão crucial é a construção do ethos camponês como uma necessidade para ficar na terra.

\footnotetext{
${ }^{2}$ Retomando, Oliveira (1995) mostra que há três abordagens teóricas sobre a questão agrária sob o modo de produção capitalista. A primeira coloca a destruição dos camponeses e a modernização dos latifúndios, a segunda concebe os camponeses e o latifúndio como permanência de relações feudais e na terceira, o modo de produção capitalista cria e recria a ambos. Oliveira e o autor desta tese seguem a terceira linha, como visto na Apresentação.
} 


\section{O ethos camponês como objeto de disputa}

Há o ethos, que é construído socialmente, mas seria ele a essência da campesinidade? Não se deve confundir ethos com "essência" camponesa. Conforme tratado nos capítulos 1, 3, 5 e 6, há no assentamento brigas/disputas por definir quem é legítimo. O ethos camponês manifesta-se, por exemplo, em trabalhar o lote, dentro das condições possíveis (o tamanho da família, materiais, financiamento etc.) e, de preferência, sem necessitar de arrendamento. Os membros dos grupos das estufas conseguem não arrendar (para melancia ou pasto), embora alguns declarem já ter feito parceria. O mesmo vale para os integrantes da associação Agro União. Entre os que arrendam o lote para plantio de melancia ou alugam o pasto, estão alguns membros, naquele momento, da associação Compartilha e outros que não estão em nenhum "coletivo" ou "semi-coletivo". Entre estes últimos, alguns conseguem não depender de arrendamento. Outros moram na parte dos tocos e não conseguem quem tenha o interesse em arrendar. Faz parte da política governamental de reforma agrária o acesso a linhas de financiamento da produção agropecuária, entre outros recursos federais e estaduais. Porém, como resíduo dessa política na maioria dos assentamentos, os moradores têm de trabalhar fora para sustentar a família, ou arrendar (ou fazer parceria), ou deixar o lote, como retratado por Miranda (1998 e 2003) e Gonçalves (2004), entre outros. Portanto, os assentados estudados são conscientes de sua condição e, ao mesmo tempo, discriminam uns aos outros entre os que são ou não "dignos" de estarem assentados, de terem ou não capacidade de trabalhar o lote.

Entre os moradores do assentamento estudado, a principal imagem manipulada é a de trabalhador rural. Um acusa o outro de "não ser digno de estar ali", de não trabalhar suficientemente. Outras acusações são as de "incriminar o assentamento", "mentir" e a de ser "vagabundo", conforme tratado no capítulo cinco. Colocou-se naquele capítulo que ficar preso a determinantes de campesinidade pode ser uma armadilha conceitual, porque a campesinidade é objeto de disputa no assentamento e está envolvida em brigas e divisões. O ethos camponês não deveria ser postulado como a essência, mas como uma situação. Este é um ponto de partida e de chegada deste trabalho. Quem resolveu ir para a terra é camponês.

É preciso retomar as idéias do autor da noção de campesinidade. Woortmann (1990) constrói uma fenomenologia do campesinato como ordem moral, a partir da etnografia brasileira: a terra é vista como um patrimônio da família e não como mero objeto de trabalho; a família é o ponto central porque é um valor moral. A campesinidade 
(e não os camponeses) é uma qualidade, presente em maior ou menor grau. Produzir para o mercado não significa estar integrado ao mesmo; estar integrado ao mercado não representa baixa campesinidade, constata o autor. Para construir seu modelo, ele faz um recorte para dizer o que é a campesinidade a partir de falas de alguns sitiantes e não para dizer que o sitiante é camponês. Assim, delineia uma ética camponesa que estaria ligada aos princípios norteadores do pensamento ocidental até a "grande transformação" moderna. São categorias comuns às sociedades camponesas: terra, família e trabalho. O trabalho familiar e o assalariamento são antinômicos, mas no sítio pode haver trabalho assalariado, que significa uma necessidade da família nos momentos de pico do ciclo agrícola; portanto, é temporário e preserva a hierarquia familiar, pois é uma "ajuda" ao chefe da família que, este sim, "trabalha". A relação de assalariamento ocorre entre sítios e não no interior de um mesmo sítio. O negócio nunca ocorre no interior do sítio, mas na rua, porque ele nega a reciprocidade. A hierarquia familiar é central. Por fim, estabelecer uma relação entre valores camponeses e conhecimento erudito é uma forte contribuição do autor. "A ética camponesa que replica os postulados da ética aristotélica se choca com essa nova ordem das coisas, pois, para ela, o direito das pessoas se sobrepõe ao direito das coisas". (...) "O valor-família que orienta a ordem social camponesa também encontra sua correspondência no pensamento erudito, de Aristóteles a Hobbes, passando pelo pensamento escolástico" (WOORTMANN, 1990: 65-8).

De modo geral, constata-se que Woortmann não postula os determinantes para ser camponês, mas, a partir de descrições etnográficas, constrói a gradação de campesinidade. Porém, alguns trabalhos baseiam-se nessa concepção de ethos de campesinidade para definir o que é ser camponês e, assim, contrapor àquilo que não corresponderia ao ethos.

Miranda (1998), por exemplo, conclui que há uma "incompatibilidade" entre o ethos de campesinidade e o projeto cooperativista da direção do MST. "De um lado, temos o projeto dos assentados de reconstruir o ethos camponês e de estabelecerem-se enquanto sitiantes autônomos, capazes de decidir sobre a organização familiar e sobre os modos de produção. De outro lado, temos os projetos dos Movimentos e demais mediadores, fiéis aos princípios economicistas e desenvolvimentistas que os orientam, trazendo propostas de produção com possibilidades de grandes rentabilidades, mas que pressupõem uma mudança do habitus camponês" (MIRANDA, 1998: 138). A autora mostra que existe o ethos, que os assentados querem reconstruir, e que o coletivismo não possui esse caráter.

A tese de Simonetti (1999) analisa a reelaboração da campesinidade. Constata que a cooperativa rompeu com a família tradicional camponesa: nuclear e hierárquica. Voltar-se 
para a família e abandonar a cooperativa é motivado pelo desejo de autonomia e liberdade. Como já foi colocado no capítulo três, são "diferentes formas de campesinidade coexistindo nessa diversidade de situações. (....) São as experiências passadas que informam a nova construção do território. As áreas plantadas ao redor dos casas no meio do sítio. Próximos a casa, a horta, o pequeno pomar e os animais de pequeno porte, ao lado da casa, a produção de grãos ou frutas. No fundo do sítio a pastagem e os animais de grande porte. Essa construção do lugar obedece o tempo cíclico" (SIMONETTI, 1999: 167-70). Segundo os dados de pesquisa da autora, $90 \%$ de seus entrevistados moravam na cidade, sem terem perdido a ligação com a terra. Vários trabalharam como metalúrgicos ou em outros serviços urbanos antes da luta pela terra. Não perderam o desejo pela terra por estarem de algum modo ligados a mesma; assim, a autora coloca-se contra o critério de técnicos do INCRA exigirem ligação direta com a terra para assentar o pretendente.

Para Schreiner (2002), o ethos camponês contrapõe-se ao modelo cooperativista do MST. Porém, o autor mostra que há formas de se reelaborar o ethos com a formação de coletividades. Segundo ele, “a concepção norteadora dualista do MST, do coletivismo versus individualismo, é reducionista das memórias plurais, das múltiplas experiências de cooperação vivenciadas nos assentamentos e em tempos anteriores, das possibilidades que a forma cooperativa pode assumir, bem como de diferentes combinações que os interesses individuais e a busca da socialização no coletivo podem engendrar. É um equívoco designar os assentados, que desenvolvem no lote o trabalho familiar, de "individuais", (SCHREINER, 2002: 378).

O trabalho de Marques (2000) aponta uma tensão existente nos assentamentos estudados entre o modo de vida camponês e o projeto de reforma agrária do governo que visa o mercado. Neste sentido, o ethos é usado para negar as ligações do camponês com o mercado. Vale lembrar que a presença da Comissão Pastoral da Terra é forte na luta pela terra em Goiás e, por isso, não aparece conflito direto com as posições coletivistas do MST. Pereira (2000), por sua vez, faz um estudo sobre dois grupos com valores distintos. Mostra que há um controle da venda dos lotes em Goiás, onde os assentados decidem sobre a "inclusão ou não".

Os quatro autores realizam uma crítica pertinente à orientação da direção do MST, que não reconhece o caráter camponês. Porém, cabe atentar para as nuanças: um autor que aponta a incompatibilidade entre a campesinidade e o cooperativismo do MST, outros que mostram a re-elaboração do ethos diante de distintas formas de associativismo e outros que destacam a tensão entre esses dois. Pode-se dizer que ocorre, de fato, uma re-elaboração do 
ethos e tensões, mas incompatibilidade os fatos não demonstram; pois, há elementos de campesinidade no trabalho coletivo, dependendo da forma como se constrói o coletivo. $\mathrm{O}$ MST demonstrou que os camponeses não querem só terra, mas também educação, cidadania, associação, comunicação, cooperação, solidariedade etc.

Outra forma de manifestação da disputa pela campesinidade no assentamento estudado é a polarização entre as famílias versus homens sozinhos. Se a base da campesinidade está no valor moral da família, o homem sozinho estaria destituído dela. Pelo observado no trabalho de campo no assentamento estudado, ser camponês manifestase na tensão entre famílias e homens sozinhos. Desde o início do assentamento, houve uma disputa entre lideranças que não queriam homens sozinhos assentados e outras que defendiam o direito de todos permanecerem, pois a conquista da terra foi em conjunto. Constata-se que uma noção de campesinidade presente entre uma parcela dos assentados discrimina os homens sozinhos, porque não seriam capazes de trabalhar todo o lote. A negação do ethos não recai diretamente sobre o ex-morador de rua, mas sobre aqueles que vivem só. A valorização da família aparece mais uma vez na formação de grupos. Como visto nos capítulos quatro e cinco, um morador participou de um grupo até 2001 e saiu porque as questões de família pesavam nas decisões do coletivo. Essa mesma pessoa foi para a luta pela terra sozinho como liderança do MST; no acampamento conheceu sua atual esposa e passou a viver em função do lote, sem participar formalmente de associações. Portanto, neste caso há uma (re)construção da campesinidade, voltada para a família e para o lote, mas que já sofreu conseqüências do valor moral da família quando participou de um grupo formado só por familiares.

Como visto em outros trabalhos e também constatado na pesquisa de campo, o desejo de ter o próprio lote também é manifestação de características camponesas. Houve um cansaço da união "forçada" durante o período de acampamentos. Além disso, concluise que ir para o lote é uma forma de evitar mais conflitos, como foi também observado por Pereira (2000). No entanto, uma família extensa que mora no mesmo lote, trabalha junto e reúne grupos de cultivo em estufas também é expressão da cultura camponesa.

A situação de relativo abandono da sede da fazenda expõe uma parte do universo camponês. Retomando um aspecto da história, a direção do Movimento decidiu colocar pessoas de fora do assentamento para tomarem conta da sede durante um período e fez uma confecção de bonés e bandeiras no local; neste sentido, foi uma das responsáveis pelo distanciamento entre moradores e sede da fazenda, nos primeiros anos do assentamento. Não houve uma apropriação do espaço público por parte dos assentados que se 
consolidasse. Naquela fração de território, há uma fragmentação dos lotes e uma dificuldade em se manter aquele espaço público como local de encontros e reuniões. Poder-se-ia dizer que a noção de espaço público, de polis, é justamente um marco de distinção entre campo e cidade. Logo, o ethos camponês negaria esse local de encontro. No entanto, foram registradas várias tentativas de apropriação da sede, principalmente por parte dos jovens que, com ajuda de terceiros, fizeram uma biblioteca comunitária, em 1999. Elementos da vida urbana, decorrentes das histórias de vida dos assentados, unem-se ao universo camponês. Atualmente, há uma comissão que cuida da sede, ocorrem festas, reuniões e curso de teatro para jovens no local.

Há uma noção imemorial presente no universo do camponês brasileiro de que a posse da terra é legitimada pelo trabalho, que o solo existe para ser trabalhado e que o sentido da vida é fazer a terra dar frutos. Muitas análises captaram e interpretaram essa noção camponesa a ponto de cunharem termos como "terra de trabalho", sendo que - como visto no primeiro capítulo - Reclus (1985: 75-98) já havia registrado esse costume de apropriação da terra pelo trabalho em algumas regiões do globo. Portanto, o trabalhador rural não pode ser "vagabundo", muito menos um "mendigo-vagabundo".

Assim, é possível destacar na entrevista, feita por Narita (2000), com José Rainha Júnior, membro do MST bastante exposto pelos meios de comunicação, um trecho em que ele refere-se aos "mendigos". Ele diz que os "mendigos" são pessoas que não se recuperam mais e, por isso, o MST é o movimento de trabalhadores sem-terra e não de mendigos semterra, que estão totalmente excluídos, mas - faz a ressalva - que alguns podem ser recuperados (NARITA, 2000: 364-5). No meu trabalho de campo, ouvi declarações como as de Abelardo e de Ademir que procuravam enfatizar que eles moraram nas ruas, mas não eram "mendigos/vagabundos".

Terra, família e trabalho são categorias coletivas compartilhadas pelos camponeses com as quais é possível apreender a totalidade do recorte analisado, que apareceram nas análises anteriores. Foi visto que a terra aparece na questão de quem é legítimo para permanecer no assentamento e na do arrendamento, que é um problema comum entre os assentados e torna-se alvo de ataques. A família ganha peso na relação com os homens solteiros, pois, trata-se da capacidade de cultivo, entre outras questões. A contraposição à idéia de "vagabundo" aponta para a importância da categoria trabalho, que será aprofundada mais a frente. Há também a oposição entre o ethos e o "espaço público" da sede, que é uma noção urbana e que é re-elaborada pelos assentados. A exposição de como essas categorias são elaboradas pelos pesquisados permite a análise do conjunto estudado. 
A distinção "trabalho/vagabundagem" é uma categoria de pensamento que atravessa a sociedade moderna, como uma consciência coletiva, segundo a definição de Durkheim (1985 [1912]). Como visto no capítulo um, as leis contra os pobres na Inglaterra do século XVI realizaram a separação entre os miseráveis "úteis", que podiam mendigar, e os "inúteis", que seriam torturados. Então, essa distinção atravessa alguns séculos e aparece como constitutiva da vida na sociedade moderna baseada no trabalho, estando na consciência coletiva do trabalhador urbano. A categoria de pensamento "trabalho" também perpassa o universo camponês; mas, a concepção para o camponês é outra do trabalho assalariado e da distinção entre trabalho e lazer. A concepção de moral camponesa baseiase no trabalho, o trabalho na terra como fonte de vida. Mas, é uma concepção moral que, historicamente, antecede a lógica econômica do modo de produção capitalista. No caso analisado, a polaridade trabalho/vadiagem tem uma carga de elementos incorporados da vida na cidade, assim como de ethos camponês.

Encontrei, por exemplo, pessoas que vieram das ruas e que, comumente, chamavam os outros de "vagabundos". Neste caso, aplica-se a análise feita por Stoffels (1977) de que é comum o "mendigo" projetar nos outros os estigmas sofridos nas ruas, como o de "vagabundo". Vale observar que os trabalhos sobre moradores de rua, como o de Stoffels e o de Neves (1983), enfatizam a diferença entre aqueles que trabalham como pedintes e aqueles que não exercem nenhuma atividade. Portanto, fatos e representações confundemse diante da polaridade "trabalhador-vagabundo". Se a sociedade moderna construiu o “delinqüente" (Cf. FOUCAULT, 1993b), pode-se dizer, por analogia, que também o fez com o "vagabundo".

\section{O questionamento dos paradigmas e as redes}

A partir dos anos 1990, o paradigma (no sentido dado por Khun) analítico do desenvolvimento do capitalismo agrário é questionado no Brasil, principalmente pelo trabalho de Abramovay (1992). Esse trabalho teve o mérito de apontar um esgotamento do paradigma do desenvolvimento do capitalismo na agricultura baseado nos trabalhos de Lênin e Kaustsky. Com base nestes dois autores não haveria como encontrar as razões de a “agricultura familiar" ter sido a principal forma social do progresso técnico no campo nos “países avançados”, segundo Abramovay (1992). Em outras palavras, a "agricultura familiar", fenômeno forte nos países capitalistas avançados, não pode ser explicada pela

herança histórica camponesa porque é determinada pelo Estado. O autor enfatiza a distinção entre o camponês e o agricultor familiar, como uma nova categoria social. Com 
base em Chayanov e Weber, demonstra que "camponês" é uma categoria antagônica ao modo de produção capitalista e que uma "agricultura familiar, altamente integrada ao mercado, capaz de incorporar os principais avanços técnicos e de responder às políticas governamentais não pode ser nem de longe caracterizada como camponesa" (ABRAMOVAY, 1992: 22). Utiliza-se de Chayanov para apontar a "identidade social do campesinato" no lugar da "diferenciação" defendida por Lênin porque, de acordo com o autor, o primeiro vai mais fundo ao explicar um segmento social que foge à lógica da economia mercantil, o que o segundo não faz. Abramovay comprova a importância do agricultor familiar no desenvolvimento da agricultura capitalista nos países centrais. Desse modo, coloca que o extermínio social do campesinato - tanto para Marx quanto para Lênin - não significou a eliminação de formas de produção familiar no desenvolvimento capitalista na agricultura. Por fim, destaca que a reprodução social do agricultor familiar depende da intervenção direta de políticas estatais de organizar a produção.

Destaca-se do trabalho de Abramovay a fato de comprovar o esgotamento de um paradigma. Porém, sua concepção de "agricultura familiar", em detrimento do conceito de camponês, não é seguida nesta tese. Porque ele imputa um aspecto "empreendedor" no personagem "agricultor familiar" europeu e estado-unidense para mostrar que não é o antigo camponês e, assim, o concebe somente por características econômicas, como "competividade", "dinamismo técnico", "capacidade de inovação" e "completa integração ao mercado" Aliás, como foi visto com Woortmann (1990), o fato de o camponês negociar excedente com o mercado não altera seu caráter.

Vale observar que, por um lado, o conceito de "agricultura familiar" vira nomeclatura oficial nos documentos e "sites" do Ministério do Desenvolvimento Agrário a partir dos anos 1990. Ver, por exemplo, a criação do Programa Nacional da Agricultura Familiar (Pronaf), em 1996. Essa medida foi elogiada por autores de diferentes matizes teóricos (SACHS, 2002: 77; MARTINS, 2000: 41) como sendo um avanço do governo federal no sentido de não direcionar o apoio exclusivamente a agricultura rentista capitalista.

Por outro, a noção de "agricultura familiar" recebe crítica. Neves (1995) desconstrói o conceito de agricultura familiar no sentido de demonstrar que por trás de uma suposta unidade há diferentes formas de organização da família e da produção. O ponto da autora é demonstrar que a metodologia baseada na agricultura familiar é economicista e, consequentemente, perde em refinamento interpretativo. 
Posto esse questionamento sobre o paradigma de desenvolvimento do capitalismo na agricultura, observa-se que os trabalhos de Ariovaldo de Oliveira (2002 [1998]) seguem o marco teórico da relação entre renda da terra e capital como determinante na análise da geografia agrária: o capital, ao se expandir para o campo, territorializando-se, ou, monopoliza o território sem territorializar-se. Ou seja, é o paradigma marxiano da renda fundiária capitalista, em que o capital percorre dois caminhos de desenvolvimento, a expansão que arrenda terra combinada com a "acumulação primitiva", que compra terra. Os textos de seus orientandos (SIMONETTI, 1999; MARQUES, 2000; BOMBARDI, 2001, para citar alguns) seguem o paradigma da renda da terra como determinante da recriação do campesinato (seja com enfoque nos aspectos econômicos ou culturais do camponês), e se opõem ao conceito de agricultura familiar. Segundo esses autores, não haveria a ruptura apontada por Abramovay (1992), entre camponês e agricultor familiar; só haveria o camponês. O campesinato - que para Abramovay se extinguiu - é recriado pelo modo de produção capitalista.

$\mathrm{Na}$ presente tese, pretendeu-se dar continuidade a luta política de Oliveira (1997), de ouvir e entender o campesinato e interpretá-lo pelo viés da luta do socialismo contra o capitalismo, e seguiu-se a orientação teórica de que o camponês é recriado pelo modo de produção capitalista; e, procurou-se mostrar as contribuições da noção de redes ao invés utilizar-se diretamente dos determinantes da renda da terra. Aliás, como visto, a obra de Latour mostra que a ciência se define mais pelo traçado de redes do que pela busca de essências. Não se descarta aqui a questão da renda da terra (e da diferenciação), apenas coloca-se outro enfoque, no qual as redes explicam melhor a dinâmica dos conflitos, complementando a análise da renda da terra. Exemplificando, um dos problemas no assentamento analisado é em relação ao arrendamento de terra, que será explicado pela conexão em rede, como será visto a frente. Em diálogo com a noção de "determinantes" na ciência, coloca-se a "rede". A noção de "rede", usada de acordo com Latour (2000a, 2000b), visto no primeiro capítulo, serve como orientação epistemológica da tese. Latour (2000b) acaba com a posição científica de busca da essência, sem, no entanto, abrir mão da ciência para explicar a realidade. Os "quase-objetos quase-sujeitos", apenas, traçam "redes", são reais, coletivos, discursivos e instáveis e arriscados; não somos nós que os criamos, mas eles que nos definem através de sua circulação e nos ligam uns aos outros. Eles traçam "redes", que "são ao mesmo tempo reais como a natureza, narradas como o

\footnotetext{
${ }^{3}$ Sobre a questão das redes e dos determinantes na ciência, ver Dias (1995: 149).
} 
discurso, coletivas como a sociedade" (LATOUR, 2000b: 12). As redes realizam mediações entre o que é humano e o não-humano, entre natureza e cultura; elas são mais ou menos longas e mais ou menos conectadas, não são globais nem locais.

Houve uma re-configuração nas redes no assentamento estudado. No início, 199899, um grupão uniu-se contra as propostas de Carlos, uma das lideranças. Esses opositores reivindicavam liberdade e espaço nos lotes individuais. Em 2004, formou-se um segundo "grupão": a maioria do assentamento conectada numa rede. Nota-se a tonalidade atual do "grupão": em torno de 28 famílias estão conectadas, pertencem a uma associação ou a três semi-coletivos das estufas. Carlos, que sofreu ataques da maioria por defender a não divisão de lotes, agora está agregado a esse "grupão". Quanto a Ednardo, que liderou a oposição a Carlos, quase não há quem o defenda atualmente no assentamento. O tamanho e a resistência dos nós da rede servem para explicar a necessidade de arrendar, ou não, o lote, como visto no tópico do ethos camponês. Estar sozinho, ou em número pequeno, leva a uma maior necessidade de arrendar o lote. Esta questão será retomada.

\section{Territórios, redes e economia solidária}

Neste tópico analisam-se as contribuições das noções de território e rede no estudo de assentamentos de reforma agrária. Amarra-se a discussão teórica do capítulo três, em que se dialogou com as contribuições trazidas pelos estudos sobre assentamentos, com as descrições e interpretações sobre os conflitos internos no capítulo cinco. Dado que o campesinato é recriado pelo modo de produção capitalista, cabe pensar o território camponês como local para a construção de relações de sociabilidade e de produção voltadas para a economia solidária (SINGER, 2002a e 2002b). Para isto, é preciso que os assentados encontrem formas (autônomas) de gerir (lidar com) os conflitos sociais, pois, dados os tipos de conflitos sociais recorrentes num assentamento, faz-se necessária uma instância pública para gestão dos mesmos em que esteja assegurada a participação de todos, com voz e voto, para encontrarem soluções em comum. Como no caso estudado não foi encontrada uma instância única para gerir os conflitos do assentamento, seguindo-se a definição de Carvalho (1998) das "associações" como meios de gerir as relações entre os assentados, a sociedade e o estado, pode-se dizer que os grupos e associação do Clarice Lispector são o caminho para que os conflitos relativos à vida pública sejam tratados de maneira horizontal. No entanto, constata-se uma incipiente formação dos moradores para a gestão democrática dos conflitos. Poderia ser esta uma das atribuiçõos dos apoiadores, desde que houvesse a demanda dos assentados. 
A territorialização é condição necessária, mas não suficiente para a economia solidária nos assentamentos, como tratado no capítulo cinco. Pois, não basta o fato de uma parcela de território do capital ser desapropriada para haver relações sociais associativas horizontais. Como visto com o trabalho de campo, há um conflito de posições entre aqueles que lutam pelo socialismo, aqueles que simplesmente querem viver em seu lote e produzir para viver, aqueles que querem se associar e exercer solidariedade. Portanto, é preciso desenvolver o aprendizado de relações democráticas.

Também, é preciso compreender o papel do território e das lutas territoriais no presente contexto de tempos-espaços globalizados. Alguns sociólogos analisam a contemparaneidade mais pela fluidez do poder do capital do que pela sua territorialização. Ou seja, a relevância do espaço nas análises sobre a luta pelo poder estaria em focar a mobilidade e não a territorialidade ${ }^{4}$. Esse retrato não contradiz a perspectiva de que as lutas por justiça social dependem da articulação entre casos locais e globais, como tratam vários trabalhos (Cf. SMITH, 1994; HARVEY, 1996; SANTOS, 2000 e 2002). A questão da fluidez em contraposição ao territorio é expressa por muitos geógrafos como sendo a "desterritorialização" uma marca fundamental de nosso tempo, de acordo com Haesbaert da Costa (1995b: 166). Segundo ele, há autores como o geógrafo Jacques Lévy e o filósofo-antropólogo Bruno Latour, entre outros, que distinguem "território" de "rede", porque "rede" leva a desterritorialização; há outros, como Raffestin, que combinam território e rede na análise e que definem a civilização atual pelo predomínio das redes. Desse modo, Haesbaert coloca que as redes estão a serviço da desterritorialização, mas integram-se também a uma dinâmica reterritorializante (HAESBAERT da COSTA, 1995b: 180). Essa relação território-rede depende da escala, pois, os processos sociais podem se manifestar como rede na escala regional-nacional e como território na escala local. $\mathrm{O}$ autor observa que se a territorialidade, em certa medida, cria solidariedade, em excesso, a mata. Assim, conclui o autor, o território deve estar aberto ao "conteúdo" proporcionado pelas redes, sem se isolar, convivendo fronteira e fluxo. Nesse debate, Souza (1995) define a noção de "território-rede" com o sentido de que cada território descontínuo é uma rede a articular dois ou mais territórios contínuos.

Dada essa discussão, observa-se que no assentamento estudado os conflitos no interior daquele território levaram a formação de redes. Encontram-se elementos que

\footnotetext{
${ }^{4}$ Para Bauman (2003), por exemplo, atualmente o território deixou de ser um trunfo e passou a ser um fardo. Para o autor, vivemos a era do fim do espaço, não que este tenha deixado de ser relevante, mas porque houve uma substituição do territorial pela mobilidade como fator de luta pelo poder.
} 
sugerem o caminho para uma economia solidária, desde que haja conexão com uma rede deste tipo ${ }^{5}$. A partir dos conflitos, surgiram no assentamento as duas associações e os grupos das estufas, que podem ser embriões de economia solidária, definida pela autogestão dos meios de produção e pelas decisões democráticas, conforme visto na Introdução. A associação Compartilha enfraqueceu- se, em comparação aos demais, porque perdeu sócios e quase não possui formas de trabalho coletivo. Os grupos das estufas, que não possuem um estatudo de associação (que juridicamente não pode ter fins lucrativos), podem estar mais próximos da economia solidária.

Seguindo a orientação de Raffestin, território implica conflito, pois é o campo das disputas de poder e, por isso, as redes são necessárias na dinâmica. A construção de um “território autônomo", no sentido da auto-gestão, passa pelas redes que o atravessam. A consolidação da economia solidária num assentamento depende da conexão com uma rede maior de praticantes desse modo de vida e de produção. A luta camponesa é definida, muitas vezes, como sendo pela autonomia e pela liberdade sobre como viver e trabalhar na terra. Porém, autonomia não remete a isolamento da fração de território. No assentamento estudado, aquela fração de território chegou a passar durante alguns meses por um semiisolamento físico (com a ponte quebrada e uma cerca de divisa trancada), o que não impediu a circulação. Mas, constata-se que a defesa da territorialização camponesa sem redes é uma limitação conceitual da análise e da luta política. Assim, é possível colocar uma posição diante do debate entre as teses de geografia sobre a territorialização da luta pela terra, presente em Fernandes (1996 e 1999), Simonetti (1999), Marques (2000), Bombardi (2001), Mitidiero (2002), entre outros.

Além de ter um pedaço de terra para morar, plantar, garantir uma alimentação (mandioca, milho, feijão, verduras, leite, frango, ovos etc., que são encontrados nos lotes), o assentamento possibilitou aos ex-moradores de rua outras conquistas. São elas:

$x \square$ Formar ou reencontrar família: quatro homens que vieram sozinhos conseguiram se casar depois da luta, sendo que um deles se casou com uma exmoradora de rua que tinha dois filhos (se conheceram no acampamento), outro conheceu sua companheira no trabalho de militância do Movimento na região metropolitana de S. Paulo, o terceiro se "amasiou” com a irmã da vizinha e o quarto está com uma senhora com dois filhos. Um quinto, sozinho, retomou contato com irmãos e tios.

\footnotetext{
${ }^{5}$ Vale mencionar que a economia solidária baseia-se na idéia de redes de ajuda mútua. Ver: www.ecosol.org.br.
} 
$X \square$ Poder estar atado a redes, distintas daquelas existentes nas ruas: os vizinhos, o MST, o Estado, a associação.

$x \square$ Manifestar habilidades paralelas ao cultivo da terra e conhecimentos não escolarizados: pedreiro, pintor, carpinteiro, comerciante etc.

Porém, não se consolidou entre eles uma alternativa socialista ao modo de produção capitalista. A associação Compartilha perdeu sócios, eles não realizam atividades em conjunto, não há auto-gestão e nem podem ter sobras a serem distribuídas. Há problemas em gerir os conflitos, o que dificulta a consolidação de grupos, a fofoca vira uma arma política e o espaço público de gestão não se solidifica.

Há uma série de trabalhos sobre assentamentos que tratam de sua organização interna e/ou enfocam a gestão das cooperativas de produção agropecuária, como visto no capítulo três [Carvalho (1998), Sizanoski (1998), Souza (1999), Simonetti (1999), Christoffoli (2000), Pereira (2000), Singer (2002a), Fabrini (2003), Feliciano (2003)]. Entre eles, alguns mostram que um problema comum nas cooperativas é em relação às formas de "retiradas" (o compartilhamento do excedente ganho com a venda da produção), em que famílias ficam insatisfeitas com aqueles que trabalham menos quando todos recebem por igual ou quando as famílias com maior número de cooperados retiram mais do que as menores. Singer (2002a) sistematiza as motivações de abandono nas cooperativas agrícolas em três: 1) baixo retorno econômico para grande investimento; 2) descontentamento com as formas de retiradas, que não incentivam aqueles que produzem mais e melhor porque são calculadas por horas trabalhadas; 3 ) insatisfação com o papel do trabalho familiar no coletivo, pois só os adultos são sócios e ganham, e, o pai de família perde o poder de "chefe" (SINGER, 2002a: 111). No caso analisado nesta tese, os grupos das estufas dividem o excedente das vendas por igual, mas descontam os dias não trabalhados. Não foram registradas disputas internas pelas retiradas. No caso das duas associações não se aplica a questão por se constituírem juridicamente como entidades sem fins lucrativos.

\section{Morador de rua como camponês, conflitos e gestão}

\section{Alternativa à vida nas ruas: a fresta}

Só é possível interpretar a presença de ex-moradores de rua nos assentamentos pelo veio da construção de alternativas ao modo de produção capitalista, no sentido da economia solidária, como vista na Introdução quando foi exposta a primeira hipótese. O 
sentido de levar moradores de rua para assentamentos de reforma agrária é o de possibilitar aqueles que estão fora das relações capitalistas de produção se inserirem numa outra forma de vida e de produção e não pretender que eles possam ser (re)colocados no mercado de trabalho assalariado.

Como resposta à primeira hipótese da tese (a mudança para o campo é uma alternativa - em relação ao modo de produção capitalista - para um problema vivido na cidade, a condição de morador de rua), constata-se que ir para o campo é uma alternativa aos moradores de rua se eles chegarem com uma maior correlação de forças, com articulações em rede dentro e fora do assentamento. Como visto no capítulo cinco, há uma dificuldade de consolidação da associação em que estão ex-moradores de rua e não há nenhum deles nos outros grupos. No entanto, ao estar na rua, o sem teto possui redes, que são grupos e instituições que os apóiam, como visto no capítulo dois. A Igreja conecta os assentados que produzem em grupos para o mercado, como visto no capítulo cinco. Portanto, as redes são necessárias para a fluidez da vida no assentamento. O isolamento é, então, um ponto crítico.

Procurou-se tratar a questão dos moradores de rua pelo viés das alternativas porque se compartilha da dificuldade de interpretá-la e analisá-la sob um único marco teórico. Pois, o morar na rua provoca os padrões civilizatórios e, assim, é bom tema para pensarmos a sociedade como um todo. Sendo assim, não se propôs explicar o sentido ou o porquê de morar nas ruas, mas observar as dinâmicas de inclusão/exclusão da sociedade e as alternativas.

\section{Os conflitos e a configuração espacial do assentamento: redes}

O foco inicial do trabalho de campo esteve num ex-morador de rua, Walter, em como ele construía as relações e como interpretava os conflitos no assentamento. Ele tem uma visão política voltada para uma luta pelo socialismo, por um socialismo elaborado na luta do movimento sindical metalúrgico. No assentamento, a partir de 2002, ele aparece unido àqueles que processam judicialmente os adversários quando há situação de conflito e forma uma associação com eles, que são tidos como cabeças fracas. Ou seja, as pessoas que recorre a processos judiciais são tidas como sujeitos que não agem por conta própria, seriam manipuladas por outras e, assim, seriam tratadas como inferiores socialmente ${ }^{6}$. Os

\footnotetext{
${ }^{6}$ Vale observar que cabeça fraca é uma categoria comum entre familiares de presos quando se referem a estes, como demonstrou Buoro (1998). Para a autora, a cabeça fraca serve para justificar a exclusão de um membro e, ao mesmo tempo, o re-insere na ordem moral familiar (BUORO, 1998: 164-5).
} 
processos jurídicos são ataques pesados contra os ex-coordenadores, na interpretação de Walter. Apesar de se dizer contra os processos, ele aparece como testemunha. Assim, um muro começa a ser construído porque os "Exculhidos" "atiraram pedras". Walter, nos primeiros encontros, colocou que no meio deles estavam existindo pessoas "corruptas e mentirosas", que só se voltavam para o próprio lote e não para a luta do MST.

Quanto aos conflitos, evidencia-se no assentamento uma disputa entre as lideranças e pelas lideranças. Num momento de formação do assentamento houve uma série de rupturas que marcaram a história. Walter é um dos elementos nessa disputa.

Walter é articulador político, ele reúne pessoas. No entanto, as pessoas se reúnem e se separam. É possível observar, nas figuras 9 e 10, esse movimento com a formação e dissolução do grupo os "Exculhidos”, que dura quatro meses e acaba por brigas internas, e, depois, com a Compartilha, que passa por dois momentos de articulação, de atar nós, até armar uma rede que ultrapassa o assentamento e se oficializa como organização em janeiro de 2004. Para Walter, estar assentado é uma maneira de resgatar sua história, de se reconciliar com seu passado, e de continuar sua militância política. Suas alianças ficaram praticamente restritas, no final de 2004, a um trabalhador rural que mora nas proximidades do assentamento e é conhecido por arrendar lotes. Sem conseguir tecer laços fortes internamente e com poucos recursos financeiros e de mão-de-obra, a rede de Walter ultrapassa o assentamento e faz um laço com um trabalhador que não tem terra mas tem dinheiro para investir no plantio. Assim, ele acredita estar ampliando a luta do Movimento, mas nem todos os assentados concordam com esta estratégia política.

Frederico também se destaca pela capacidade de reunir pessoas. Ele encabeça a associação Agro União reunindo-se com famílias que defenderam a ida para os lotes, entre 1998 e início de 2000, e que a partir de 2003 sentiram necessidade de se associar. Foi uma rede interna de moradores que se cristlizou numa organização e que, a partir de 2004, se ramificou para fora do assentamento conseguindo recursos materiais de instituições internacionais.

De 2002 para 2003, consolidam-se três grupos com produção semi-coletiva de pimentões em estufas. Carlos e Rosa são organizadores de dois dos grupos. Os grupos das estufas têm conexão com um padre que lhes financiou a construção das primeiras estufas. Ao ter ramificações para fora do assentamente, esta rede com a Igreja ajudou a fortelecer esses grupos.

A interface da associação Agro União com membros dos grupos das estufas e com alguns "independentes" configura a maior rede no assentamento e, portanto, tem 
capacidade de controlar o fluxo de exploração realizada de fora para dentro no assentamento. Em 2004, esse conjunto de pessoas mostrou que elas formam uma rede que tem potencial para controlar se os produtores de melancia vizinhos poderão arrendar lotes, realizar parcerias, ou não.

Destaca-se nas figuras 10 e 11 , sobre as disputas internas e os grupos formados, como a fração de território é moldada por esse jogo espacial de alianças e ataques. A importância de uma análise na escala local é mostrar que essa dinâmica interna é inerente ao território e que, na escala nacional e/ou global, esse território é um nó numa rede maior de luta por justiça social. As figuras mostram desenhos que se sobrepõem ao longo dos anos, apresentando a variação do poder de cada grupo, conforme a concepção de poder usado por Raffestin (1993). Na fração territorial que é o assentamento, os lotes são nós; assim, a movimentação de ataques e alianças entre os moradores formando grupos e associações é a rede que o atravessa e permite fluxo com o exterior: venda, compra, financiamento, informações etc.

Conforme analisado por Carvalho (1998), a gestão no assentamento é mediada pelas associações. A associação é o meio de comunicação com a sociedade como um todo. $\mathrm{O}$ assentamento estudado não foge a essa regra.

Entre os grupos e associações, a turma das estufas apresenta um bom resultado nas condições de moradia dos lotes. Como ninguém tinha experiência em trabalhar com estufas, a atividade foi um aprendizado para todos. Os membros da Agro União começaram, em 2004, a se distanciar da necessidade de arrendar seus lotes (ou de fazer parcerias) e apresentaram bons resultados em fortalecer uma rede que os conecta com entidades externas ao assentamento para obter apoio e financiamento. A presença de famílias extensas, com mais de dois lotes, fortalece a associação (e o grupo das estufas) com a existência de lotes só para cultivo e criação sem moradia.

A forte presença de gado no assentamento segue uma tendência geral dos assentamentos de reforma agrária. Os membros da Agro União, dos grupos das estufas e alguns que não estão em grupos apresentam um número significativo de cabeças de gado em comparação com os restantes. Pelo que se verifica em dados sobre os assentamentos de reforma agrária no país, há uma tendência, principalmente, nas regiões Sul e Sudeste, de privilegiar a criação de gado. Por exemplo, segundo o relatório FAO/PNUD - MARA (1992: 15), a carne bovina está em quarto lugar na lista de maior quantidade de produção, ficando atrás somente da mandioca, do milho e do arroz. Pode-se verificar também a forte presença de gado no assentamento Fazendas Reunidas (Cf. SIMONETTI, 1999). 
Nota-se que o fato de estar inserido numa rede, conforme conceituação anteriormente, propicia melhorias nas condições de moradia e de vida no lote. Portanto, conectar-se a uma rede com laços fortes é uma das garantias de permanência no lote e de melhoria de vida nos assentamentos de reforma agrária. No assentamento analisado, os ataques e as alianças, que tecem as redes e que geram associações, marcaram - entre os moradores - uma diferenciação ${ }^{7}$.

Durante o período de trabalho de campo, constatou-se a presença daquilo que D’Incao e Roy (1995) caracterizaram como "invalidações recíprocas". Porém, a dinâmica do assentamento foi além deste ponto e houve a formação dos grupos analisados anteriormente. Resta uma tensão entre as "invalidações recíprocas" e aqueles que apresentam melhorias de vida.

Dentre os grupos e associação, é possível observar a tendência de os sítios assumirem uma configuração espacial conforme os grupos de pertencimento. Ou seja, há processos distintos de acordo com o grupo que cada assentado pertence. Os exemplos são a semelhança entre os sítios dos membros da associação Agro União, em que - aos poucos todos constroem os vários lotes de pasto do sistema rotacionário (Voisin), e a presença das estufas entre aqueles que aderem a esses grupos. Nota-se, também, um mimetismo social porque as placas nas porteiras com nomes de sítio começaram a aparecer numa mesma rua. Num outro caso estudado, Bombardi (2001: 511) constatou uma homogeneização dos sítios devido às culturas e técnicas de cultivo em comum a um grupo com a mesma origem étnica. Esta autora mostra como a mesma origem cultural dos assentados e a troca entre os vizinhos determinaram a homogeneização espacial dos sítios.

\section{Três formas de gestão dos conflitos no assentamento}

No capítulo seis, foram vistos os principais conflitos internos do assentamento e procurou-se interpretá-los. Agora, cabe analisá-los. De modo geral, constatou-se que a situação dos moradores é de dependência do Estado e de início de uma tentativa de autogestão dos conflitos. Conclui-se que há uma demanda por uma instância interna de gestão de conflitos; porém, a questão é como constituí-la legitimamente. Verifica-se que há a

\footnotetext{
${ }^{7}$ Há uma tradição de trabalhos sobre a questão agrária que tratam da diferenciação interna do campesinato. Ver: Lênin e Kautsky (1986), que postulam o desaparecimento do campesinato; Chayanov (1974), que se contrapõe à visão leninista mostrando a importância da unidade econômica camponesa para o desenvolvimento da economia nacional; Shanin (1983), que comprova a permanência do campesinato ao longo do século XX e aprofunda a noção de mobilidade cíclica (ou seja, o desenvolvimento do campesinato não é linear, há alternância entre expansão e contração da produção camponesa). Sigaud (1979), Lopes
} 
possibilidade de gestão pública dos conflitos no assentamento, conforme a segunda hipóotese; pois, há instâncias democráticas como a assembléias e comissões abertas a participação de todos os assentados. Cabe problematizar como ocorre essa gestão pública.

No primeiro caso, o processo civil para reaver uma partilha de dinheiro, houve manifestações que lembram o que Franco (1983) denominou de "código do sertão" e o seu oposto, a busca de direitos pelo Estado. Se o "código do sertão" revela elementos da campesinidade ao final do século XIX, constata-se que procurar a Justiça não os nega. Aliás, há uma literatura que trata da questão da busca pela Justiça por parte dos camponeses (Cf. SIGAUD, 1979; MOURA, 1988, JUSTO, 2002). Na verdade, é possível encontrar no incômodo em ser processado mais do que um medo da lei, uma intenção de fugir da tutela estatal. Ou seja, uma parcela dos assentados manifesta a vontade de que os conflitos fossem geridos no assentamento e aqueles que procuram a Justiça estatal são vistos como minoria. O recurso ao Judiciário não foi a melhor forma de gerir o conflito porque ressoou um ciclo de vontade de vingança, via processos recíprocos: repõe-se o mesmo tipo de conflito, sem dar margem para o surgimento de novos tipos de conflito.

Os recursos à Justiça estatal possuem uma série de significados: demanda por arbitragem e/ou por auxílio externo; necessidade de mais laços fora do assentamento do que dentro; os mais "fracos e/ou sozinhos" é que registram boletins de ocorrência policial contra outros assentados; e, a presença de uma forma urbana e moderna de gerir conflitos e de exigir direitos em convivência com um código moral que se envergonha diante da lei. No entanto, alguns moradores expressam que quando o acampamento era gerido pelos integrantes era melhor do que agora em que se busca pelo Estado. Portanto, apresenta-se um potencial diálogo entre formas estatais e não-estatais de gestão dos conflitos. Isto remete ao trabalho de Santos (1997), que postula a necessidade de uma concepção multicultural de direitos humanos. $\mathrm{O}$ assentamento pode caminhar para a construção de regras plurais de convivência que incorporem os elementos culturais dos moradores e premissas do Estado de direito.

Há uma configuração espacial no assentamento que demanda por justiça estatal, que não deixa de ser uma forma pública de tratar os conflitos. Porém, há pessoas que negam as tentativas de organização da maioria e, consequentemente, atrapalham a consolidação de uma esfera pública no assentamento. Com base na teoria de Black (1998), é possível afirmar que pouca lei recai quando as partes envolvidas numa ação civil ou demonstram as diferentes formas de resistência, reprodução e diferenciação do campesinato. 
penal são de baixo status social. Portanto, as partes impetrantes de processos judiciais no assentamento dificilmente terão resultados favoráveis. Além disso, no capítulo dois, foi exposta a análise de Black sobre a forma e a quantidade de lei que recai sobre o morador de rua. É a formulação mais aprofundada sobre a questão do controle social no contexto da transformação do Estado de Bem-Estar Social para o de um Estado penal. Sendo assim, vale retomar o ensinamento de Black de que para se mudar o espaço social deve-se retirar lei. Logo, a luta em comum no assentamento deveria ser pela retirada de lei para mudar o espaço social e não por aplicação da lei.

Explicando melhor, Black (1998) demonstra que o controle social é inerente à vida em sociedade e que varia de forma de acordo com contexto espaço-temporal. O autor sintetiza aquilo que sociologicamente é conhecido como controle social, ou gestão de conflitos, por meio da análise da estrutura social do certo e do errado. Segundo ele, o controle social ocorre em todo o universo social onde quer que seres humanos interajam e corresponde ao modo como os indivíduos definem e respondem ao comportamento desviante. Conseqüentemente, o controle social apresenta uma gama variável, conforme os contextos locais, sócio-culturais, históricos e que inclui e ultrapassa o controle estatal, ou seja, a lei. Isto é, pode variar de acordo com diferentes estilos, do mais formal e legal ao mais informal e casual. Então, para se mudar uma configuração sócio-espacial deve-se mudar ou diminuir determinado tipo de controlo social. A contribuição do trabalho de Black está em mostrar que não há alteração no espaço social apenas com a maior aplicação do controle social do estilo penal.

Constata-se que a lei, independentemente do resultado de sua aplicação, é mais um recurso no repertório de controle social dos assentados. Ainda com base na teoria de Black (1998), é possível afirmar que no assentamento estudado as formas de controle social apresentam um espectro que vai da fofoca à lei. Nos capítulos cinco e seis, foram percorridos os circuitos que as fofocas e a busca pela lei traçam, conforme as figuras 9 e 11. Em certo sentido, o caminho das fofocas, ou intrigas, no assentamento corresponde ao movimento das “invalidações recíprocas”. Assim, foi possível mapear uma gama de conflitos e de formas de controle presente no local que dá feições àquela fração de território.

No segundo caso a ser analisado, um exemplo de tentativa de gestão pública, houve manifestações ambíguas e ambivalentes em relação ao pivô do caso. Essas ambigüidades e ambivalências devem ser analisadas. No sexto capítulo foi colocado que era comum ouvir 
em campo que as pessoas sentem pena em relação aos filhos de Robério. É um paradoxo, pois este morador expressou sua vontade de deixar o local atacando todo o assentamento, a maioria dos assentados não queria mais sua presença ali, mas o toleram por pena dos filhos. Robério disse que alguns moradores queriam retirar a guarda dos seus filhos; é assim que ele viu o dó. Este ponto é destacado porque é possível ler a cultura - no sentido colocado por Geertz - que se enuncia no assentamento naquele momento. Estamos diante de categoria - pena - usada por diferentes assentados e não apenas por um interlocutor privilegiado. Encontra-se algo que revela o conjunto de significados daquela comunidade, revela também a relação dela com os conflitos e com a existência, ou não, de uma instância pública de lidar com estes. Para uma análise das "ambivalências" e "ambigüidades", a referência é Augé (1999: 43-55) ${ }^{8}$, que se utiliza dessas categorias para analisar os rituais sociais. Guardando as devidas proporções em relação a rituais, o que está presente na categoria de pensamento pena é uma passagem de ida e volta entre inclusão/exclusão. Dizer que há "ambivalência" numa ação, ou num sujeito, é apontar para união de contrários, há o "bom” e o "mau”. Então, a pessoa que traz problemas para o assentamento é "má", mas possui filhos que não são culpados, são "bons". Como é sentido dó/pena, aqueles que sentem são "bons" porque absolvem os filhos da culpa do pai. A situação toda é ambígua porque a maioria dos moradores não pode retirar Robério do assentamento, mas ele também não é integrado aos grupos ou associações mais fortes; fica-se no "nem uma coisa, nem outra"; não surge um terceiro termo para recolocar a questão num outro nível. Ou seja, a ambigüidade de não ser aceito no assentamento e de não ser mandado embora permanece porque a reunião de moradores toma uma posição indicativa, mas quem pode decidir é o INCRA, que não compareceu para realizar seu dever. Assim, os moradores não se reconhecem como instância de decisão e não são atendidos por quem decide de fato. Como Augé coloca, a ambigüidade é provisória. Se, nesse momento, Robério é uma alteridade, já houve identidade com ele. Atualmente, Robério está no seu lote sem realizar novos ataques ao assentamento. Porém, ele se isolou de todos dos demais, inclusive da Compartilha, e os outros o isolaram. As categorias dó e pena podem representar uma identificação com o sentimento do outro e colocar-se no lugar dele, numa posição horizontal ou simétrica, ou como "piedade", em que o outro é destituído de qualquer atributo a não ser o de sofrimento. Nesta segunda conotação, o outro é inferiorizado, então, cria-se um espaço vertical, ou hierarquizado, de relacionamento social. Desse modo, é

\footnotetext{
${ }^{8}$ Para as aproximações e distanciamentos entre as teorias de Geertz e Augé, ver as discussões metodológicas contidas na Introdução desta tese.
} 
possível incorporar à comunidade aquele que incomoda, colocando-o numa posição subalterna.

No terceiro caso, houve a convivência entre Estado e gestão pública. Formou-se uma comissão para tratar dos problemas do assentamento com o apoio do INCRA. Este órgão desfez a "venda" de um lote. No entanto, há necessidade de aumentar a participação e a legitimidade da comissão. Numa reunião, em 02/11/2004, os moradores ligados aos grupos das estufas e à associação Agro União e alguns "independentes" se manifestaram contra os membros da associação Compartilha com o seguinte conteúdo: nós estamos com a verdade, que é estar contra aqueles que só atacaram até agora. Estamos diante de uma ordem moral, de certa noção de justiça, de um elemento do campesinato que diz um basta àquilo que vinha sendo tolerado, que precisa ser interpretado como significativo daquela cultura. Há uma tensão entre essa noção e os direitos civis de defesa e de julgamento “imparcial", elementos do chamado Estado democrático de direito. A tensão pode diminuir em proporção direta ao número de ataques do outro lado, ou pode haver a construção de um muro simbólico entre as partes em conflito.

Vale aprofundar a questão da "mediação", ou melhor, das terceiras partes que atuam na luta dos sem terra. Fernandes (1999), por exemplo, opta pela noção de "articulação" em relação aos colaboradores da luta dos sem terra, em oposição ao termo "mediadores", que daria um sentido de "intervenção e/ou arbitragem". Para o autor, a direção política do Movimento deve ser dos trabalhadores rurais, sem intervenções, porém, o Movimento também necessita do apoio, resultante de "articulações" (FERNANDES, 1999: 180, nota 44). A posição de Fernandes revela que a terceira parte deve ser partidária da causa.

A teoria de Black (1998) sobre a terceira parte classifica e analisa essas posições descritas. Para o autor, a terceira parte tem duas dimensões: a natureza da intervenção (partidária ou não) e o grau da intervenção (autoritarismo). A primeira dimensão refere-se àquelas pessoas que desempenham o papel de apoiadores (support) das partes em conflito e a segunda refere-se aos que procuram estabelecer um acordo (settlement) entre as partes em conflito, ou punir os responsáveis por ele. Pelo montante de assistência e risco assumido em prol de uma das partes, a terceira parte pode ser classificada pelo grau crescente de partidarismo em cinco modalidades: informante (informer), conselheiro (adviser), advogado (advocate), aliado (ally) e representante (surrogate). Na segunda dimensão da intervenção, com o papel de estabelecer um acordo no conflito sem tomar 
partido, o comportamento dos grupos é classificado pelo grau crescente de autoritarismo da atuação: pacificador amigável (friendly peacemaker), mediador (mediator), árbitro (arbitrator), juiz (judge), pacificador repressivo (repressive peacemaker). O pacificador amigável age no sentido de fazer as partes abandonarem o conflito; o mediador procura conhecer o conflito e encontrar soluções satisfatórias para ambas as partes; o árbitro enuncia uma resolução ao conflito; o juiz separa os adversários, toma uma decisão que coloca fim ao conflito e obriga as partes a acatarem a decisão, e, o pacificador repressivo é indiferente ao conteúdo do conflito, apenas quer que o mesmo acabe o mais rápido possível e com os meios que forem necessários. Importante ressaltar que a perspectiva do autor é histórica e inter-cultural, então as modalidades não se restringem ao uso corrente dado a elas, como juiz e advogado.

De acordo com essa teoria, é possível constatar certo uso indiscriminado do termo mediador na literatura para descrever de modo genérico qualquer dimensão de atuação de terceira parte. Porém, segundo Black, mediador é sempre uma posição não partidária. É neste sentido que é usado no trabalho de D’Incao e Roy (1995).

Quanto à proposta de Fernandes (1999), o articulador pode ser classificado como um papel de apoiador e estaria entre o aliado e o representante no seu grau de partidarismo, pois toma a causa para si até o limite máximo (representante), ou não chega a esse limite (aliado). Ao aplicar a tipologia, pode-se verificar na posição de Fernandes um alto grau de partidarismo e na de D`Incao e Roy algum grau de autoritarismo. Por um lado, o partidarismo do articulador, proposto por Fernandes, dificulta o distanciamento crítico. Por outro, a "mediação competente" dos conflitos, como realizada por D'Incao e Roy (1995: 164 e 262), sem que a comunidade a tenha solicitado pode ser revelador de certo grau de autoritarismo.

Voltando para o caso estudado, constata-se nas formas como os moradores gerem os conflitos a convivência entre o espaço horizontal, das assembléias, e o hierárquico entre as famílias (maior o tamanho, maior o poder). O primeiro, lentamente, ganha volume, porque são alguns moradores que sentem necessidade de se reunir em grupo/associações para tratarem de problemas comuns. Mas, a ordem moral familiar, hierárquica, continua a ter papel de destaque. Portanto, essa duas esferas, a do espaço horizontal e a do vertical, se friccionam. Assim, a constituição de um espaço público de gestão pode ser realizada, num diálogo entre o ritmo dos assentados e as intervenções externas de pesquisadores e/ou militantes. O que se relaciona com a necessidade de os moradores aprenderem ou 
fortalecerem os processos democráticos de gestão dos conflitos e da produção material. Esta questão será retomada com as posições de Santos (2002) e Quijano (2002).

\section{Abstrações e continuidade da luta}

Vale destacar que essa tese aponta para um outro olhar sobre os conflitos internos ao se colocar o "isolamento" dos "individualistas" como uma forma de evitar (mais) conflitos e, assim, ir além da polarização "coletivista x individualista". Portanto, o suposto isolamento não quer dizer afastamento de uma luta maior. No caso estudado, muitos daqueles que defenderam, em 1999, a posição contrária a morar em agrovila estão envolvidos, desde 2003, com a formação e consolidação de associações.

Trazendo a concepção de Harvey (1996) de que há na produção do espaço diferentes tipos e níveis de abstração, que se expressam tanto no discurso militante quanto como categoria para interpretar os fatos, é possível classificar a dinâmica no assentamento. Para Harvey, a luta por justiça social passa pela relação entre o local, o espaço e o meio ambiente, no sentido de que o alvo seja o mais amplo, estas três categorias são níveis e tipos distintos de abstração, que todos os grupos sociais são capazes de operar. A relação entre as três é mais complexa do que uma simples hierarquia. $\mathrm{O}$ que é justo para um dado local pode não ser para o meio ambiente; o que vale para um determinado espaço não necessariamente beneficia uma localidade ali contida.

Toma-se aqui o assentamento pelo "local", a luta do MST como um todo pelo "espaço" e o "meio ambiente" como algo que é local e global. Assim, os moradores que estão sozinhos no lote representam um nível de abstração e aqueles que estão organizados em grupos semi-coletivos ou em associações apresentam outro. Como as abstrações são diferentes, pode-se perceber porque as lutas internas divergem. As abstrações se expressam também como interesses e práticas distintas. Entre as famílias da associação Agro União e dos grupos das estufas, há membros que participam da direção regional do MST, porém, as posições oficiais deste movimento sobre o modo de produção, podem influenciar na organização destes grupos, não são determinantes. Na associação Compartilha, uma família coloca-se como tendo ligação com a direção estadual do Movimento. Os demais moradores se ligam pouco à organização do Movimento. A continuidade de luta do MST não é do interesse imediato de todos, mesmo que ela represente a possibilidade de estar inserido numa rede maior. A discussão que se coloca sobre as diferentes abstrações é a constituição do território (ou sua fração) e a possibilidade de ampliar os seus limites. Pode- 
se associar o tipo de abstração com o tamanho das redes às quais os assentados estão conectados. Em outras palavras, estamos diante da clássica questão da escala geográfica de análise. Do assentamento para a cidade, para o Estado, para o país e para o globo e viceversa, ou do assentamento para o MST e para o movimento camponês de escala mundial são diferentes abstrações ou escalas (dependente da conceituação que se adote), que informam e orientam o pensar e o agir da luta pela terra. Aliás, a pergunta fundamental em jogo é: qual a capacidade deles de formar, manter e ampliar as redes?

Os nós mais fortes e os mais fracos das redes dizem respeito a se conectar além dos núcleos familiares. Aquele morador que não está em nenhuma associação, grupo ou rede não contribuiria diretamente para a continuidade da luta dos demais sem terra. Alguns moradores apostam somente nos laços familiares como garantia de união, porém não tecem redes. Têm uma visão circunscrita, ao menos temporariamente, a esse tipo de abstração. Outros atacam essa visão justamente porque essa delimitação seria estreita. Porém, um desses lados que atacam a união restrita ao plano familiar não conseguiu que os laços mais amplos sejam fortes e, conseqüentemente, não construiu uma rede resistente. A associação Agro União serve como contraponto, pois uniu moradores de distintas famílias e se conectou a organizações não-governamentais de escala global.

\section{Estado, gestão pública e emancipação}

Os debates sobre como interpretar o MST trazem questões como a relação do Movimento com o Estado, as formas de gestão da luta, a democracia interna e os projetos emancipatórios, como visto no capítulo três. Entre os autores, Navarro (2002) propõe-se a analisar o MST independentemente da conjuntura política e acaba fazendo uma defesa do contexto político nacional para atacar a orientação política do movimento. A principal crítica que dirige ao MST é de ser essencialmente não-democrático e hierarquizante. Essas críticas são importantes e contribuem para a luta, mas possuem um caráter externo ao Movimento. Carvalho (2002), ao responder as críticas de Navarro, argumenta que o Movimento tem uma dinâmica nos seus centros de decisão que impede a cristalização da estrutura de poder. Uma das razões está nas ocupações de terras, que são decididas e organizadas por "movimentos de massa local” e, por isso, é impossível passá-las para uma instância organizacional burocrática centralizada. Sobre o debate entre esses dois autores, Santos (2002) coloca que:

Os estudos sobre o MST abrem toda uma série de perguntas sobre a relação entre as alternativas econômicas e democracia interna. Neste sentido, este livro [Produzir para 
Viver] serve para iniciar um debate que pode ser frutífero em relação à evolução futura do movimento, cujas realizações são reconhecidas tanto pelos autores dos capítulos quanto por movimentos e organizações de todo o mundo. $\mathrm{O}$ debate refere-se à forma pela qual as realizações do MST foram ou não acompanhadas pela criação de uma estrutura interna democrática e aberta (SANTOS, 2002: 69-70).

A questão da democracia é trabalhada por Quijano (2002), ao comentar o debate anteriormente mencionado. Para o autor, o debate gira em torno das questões da democracia e do socialismo. O autor resolve essas questões ao tratar do problema da democracia. Ele define democracia como uma estrutura de relações sociais na qual as pessoas têm controle autônomo sobre todas as dimensões da vida individual e sobre a autoridade coletiva, o que pressupõe um quadro institucional para expressar e praticar tal controle. O Estado-nação não corresponderia mais a esse quadro institucional. Assim, a democracia é condição sine qua non para uma revolução social. Nesta perspectiva, não poderia existir uma economia alternativa, nem sistemas alternativos de produção, sem uma estrutura de autoridade alternativa ao Estado capitalista. "A democracia requer um contexto no qual o sistema de autoridade apóie a reprodução de um sistema de controle democrático da autoridade" (QUIJANO, 2002: 511-2).

Pode-se dizer que Quijano (2002) e Santos (2002) estão trabalhando a democracia e a emancipação em diferentes níveis de abstração. Para Quijano, a democracia é necessária para a ação autônoma, que vai da esfera da subjetividade até instâncias supra-nacionais de poder. Santos, por sua vez, elabora um projeto emancipatório que passa pelo conhecimento (a ruptura da distinção entre conhecimento científico e o senso comum), pelo Estado, pelo global e pelo local.

Analisa-se o assentamento estudado com base nesses argumentos para ressaltar os elementos emancipatórios, surgidos do saber local, conforme referência a Geertz (1983). A formação de associações, em 2003, propiciou o início de uma gestão do assentamento que não existia no início da pesquisa, em 2001. Elas facilitam a comunicação com o Estado e podem servir para aumentar a independência dos assentados em relação a este. As associações e os grupos das estufas não se constituem em si como empreendimentos de economia solidária, pois não são socialistas e nem cooperativas, mas têm o potencial para tal fim. Podem também se consolidar como instância de gestão dos conflitos relativos à vida pública no assentamento.

Conclui-se que há necessidade de se consolidar uma instância pública de gestão que garanta autonomia em relação ao Estado. Há uma incipiente formação dos moradores para 
gerir democraticamente os conflitos. Para se educar para a democracia é preciso praticá-la. Aprender a democracia com a prática e constituir um outro modo de vida e de produção voltado para a economia solidária são potenciais do assentamento que dependem de desdobramentos futuros. Desde já, os assentados estão se conectando em redes e a economia solidária também se baseia em redes.

\section{Possíveis generalizações}

Para encerrar, vale trazer alguns pontos que, na comparação entre o trabalho de campo e a literatura sobre assentamentos de reforma agrária, são passíveis de generalização. Primeiro, a noção de ethos de campesinidade como instrumento de análise é uma rua de mão dupla, tanto serve para mostrar um movimento dos assentados de resgate de identidade quanto para manifestar movimentos internos de exclusão/inclusão.

Segundo, os conflitos sociais estão presentes nos assentamentos e são motor da dinâmica e pode-se concluir, como visto no capítulo três, que há um ritmo comum aos assentamentos em que durante os três ou cinco primeiros anos de formação há um andamento mais acelerado de formação e dissolução de grupos, associação e cooperativas. Por último, há uma tendência de transformação dos lotes em sítios camponeses, num movimento de apropriação do lugar pelos moradores.

No próximo capítulo são tecidas algumas considerações finais. É feito um balanço geral da tese, destacando-se as principais contribuições da pesquisa realizada. 


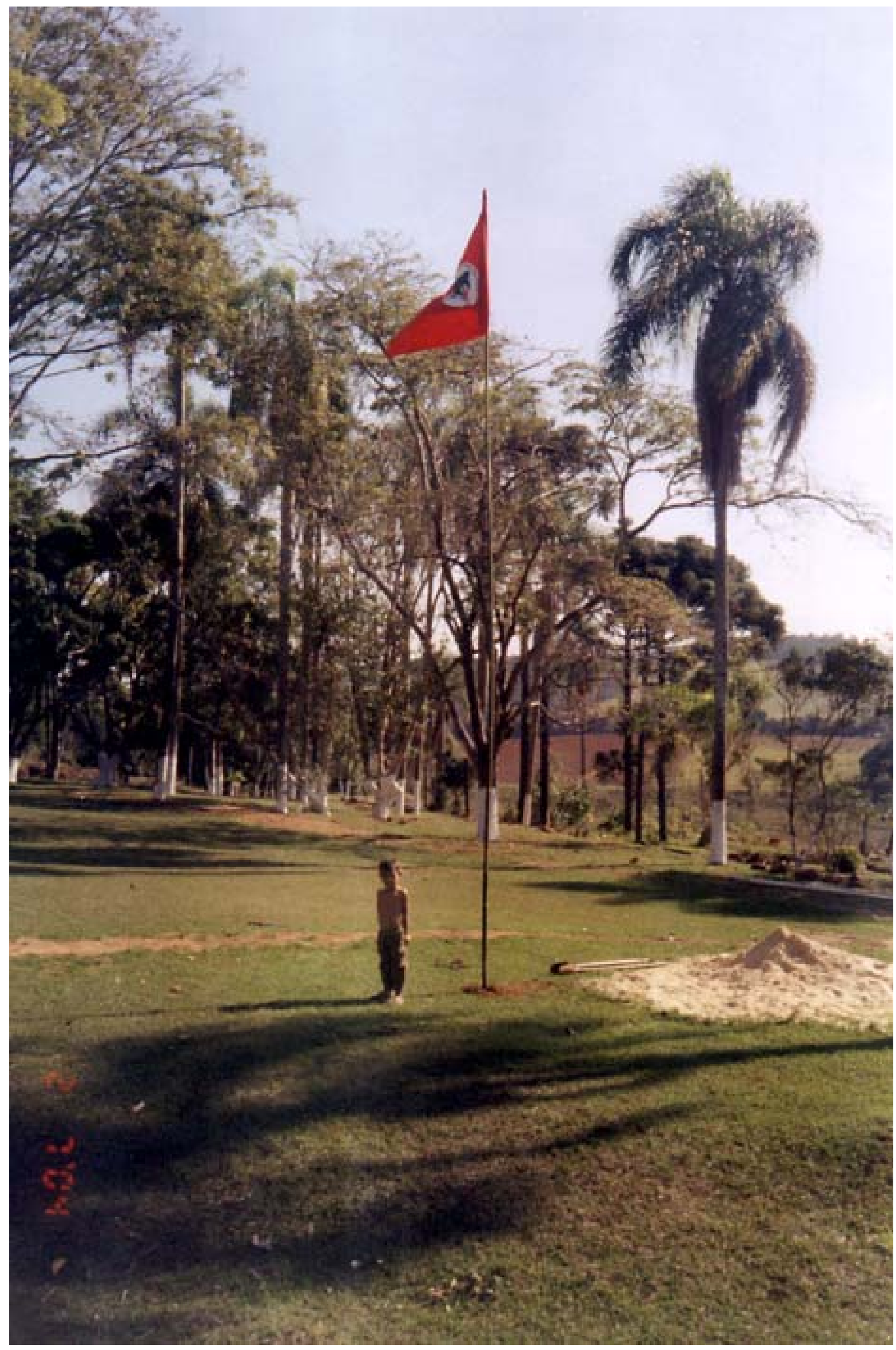

Foto 7 


\section{Considerações finais}

\section{Das questões e do objeto}

Esta pesquisa trata dos conflitos internos relativos à organização da vida coletiva no assentamento e da relação entre a trajetória de vida daqueles que vieram das ruas e o MST. $\mathrm{O}$ assentamento estudado insere-se num contexto em que a Fraternidade Povo da Rua aproxima-se do MST, nos anos 1990, e começam a levar moradores de rua de São Paulo para a luta pela terra. Essa aproximação gerou a regional grande São Paulo do MST.

A escolha do assentamento deve-se ao fato de ser a segunda experiência com moradores de rua a entrarem para a luta e a primeira com mais de 10 pessoas nestas condições. Apesar de haver outros trabalhos sobre assentamento ou acampamento com exmoradores de rua, esta é a primeira tese em geografia a tratar diretamente desta questão.

Foram levantadas duas hipóteses, comprovadas ao longo da tese. Na primeira, é assumido que a mudança para o campo pode ser uma alternativa para um problema vivido na cidade, a condição de morador de rua. A noção de "alternativa" é entendida em contraposição ao mundo do emprego assalariado, base do modo de produção capitalista, no sentido colocado por Singer (1998 e 2002b). Procurou-se enfocar como se pode construir uma economia solidária no assentamento, no sentido de mostrar quais são os avanços e as limitações na realização desse processo.

A segunda hipótese coloca que, numa fração de território potencialmente alternativa ao modo de produção capitalista, desenvolvem- se formas de gestão pública dos conflitos sociais internos referentes à vida coletiva no assentamento. Basicamente, a diferença entre a gestão pública e a estatal consiste no seguinte. A gestão estatal dos conflitos não é realizada pelo público envolvido, mas por técnicos operadores da lei distantes do cotidiano gerador do conflito, e, principalmente, o controle social exercido pelas leis baseia-se em distinções sociais (Cf. BLACK, 1998). A gestão pública dos conflitos diz respeito ao controle social e à apropriação do espaço feita pela população de um dado local, no caso um assentamento de reforma agrária. É este movimento que transforma o espaço em território, no sentido definido por Raffestin (1993). A gestão pública, ou "gestão democrática”, baseia-se na concepção colocada por Quijano (2002),

que pressupõe um "sistema de controle democrático da autoridade" referenciado em instâncias supranacionais (QUIJANO, 2002: 511-2). 
Essas duas hipóteses, que serão retomadas, ressoam uma concepção de que um campo científico define-se pelas questões feitas à realidade (Cf. CAPEL SAEZ, 1999); no caso da geografia, as perguntas estão diretamente relacionadas ao espaço.

Houve neste trabalho uma preocupação com a relação pesquisador-pesquisado, tendo como orientação reflexões sobre ciência, ética e justiça social. Uma das referências para o trabalho de campo foi o ensinamento de Roberto Cardoso de Oliveira (2000: 53-72) sobre a fusão de horizontes: para se compreender o Outro, este deve ser estimulado a nos compreender. Três recortes metodológicos percorrem essas reflexões: as relações de poder entre pesquisador e pesquisado e a possibilidade de acesso ao Outro; o caráter definidor da ciência geográfica e a ética; e, a relação entre ciência e justiça social. Esses três recortes amarram-se na seguinte questão: fazer ciência como, por que e para quem? Pode-se concluir, com base nos trabalhos de Latour (2000a e b), que o conhecimento científico é uma disputa por estabelecer verdades que são validadas por redes.

\section{Das teorias}

Em primeiro lugar, verifica-se como a modernidade trata o campesinato e a mendicância e quais os potenciais contidos neste tema de pesquisa. $O$ pensamento moderno de autores como Comte, Ratzel, Marx e Reclus apresenta ambigüidades e ambivalências sobre camponês e morador de rua. Oscila entre a extinção ou a não extinção do campesinato e entre colocar a mendicância como um fenômeno social ou natural. Com base no trabalho de Santos (2000), pode-se classificar Comte e Ratzel como representantes do conhecimento-regulação e Marx e Reclus, do conhecimento-emancipação. São duas metades do pensamento moderno, porém, o modo de produção capitalista tornou dominante o conhecimento-regulação em detrimento da emancipação. Para Santos, é preciso reinventar o projeto emancipatório. Cabe a nós encontramos formas potencialmente emancipatórias.

Questionar a episteme moderna com base em Foucault (1993b) possibilita constatar que o poder disciplinar individualiza, em primeiro lugar, os "desviantes", constituindo-os como sujeitos assujeitados. Para esse autor, o poder disciplinar caracteriza a sociedade moderna. "Num sistema de disciplina, a criança é mais individualizada que o adulto, o doente o é antes do homem são, o louco e delinqüente mais que o normal e o nãodelinqüente" (FOUCAULT, 1993a: 171). Além disso, é importante dizer que essas individualizações de pobres, loucos, crianças, mendigos e trabalhadores decorrem do fato 
de a pobreza ter emergido como a grande questão social, política e intelectual do século XIX.

Num outro registro, a posição não-moderna, de Latour (2000b), permite um posicionamento epistemológico de colocar camponês e morador de rua como pontos centrais para explicar a sociedade e os processos de exclusão. O enfoque do autor é o estatuto do conhecimento científico na sociedade moderna. Ele mostra que esse conhecimento traça redes, assim como as demais formas de conhecimento. A diferença entre as formas de conhecimento depende do tamanho das redes que mobilizam. Para o autor, a ciência caminha por redes e não pela busca de essências. Neste sentido, o registro epistemológico do trabalho de Latour permite a contraposição a visões que buscam a essência do campesinato. Pois, esta tese dedica-se ao desafio de lidar com aqueles que vieram das ruas sem cair da defesa de uma essência para a permanência na terra.

A noção de redes, usada por Latour (2000a e 2000b) e por Raffestin (1993), serviu de instrumento para mapear os conflitos sociais no assentamento. Tal noção fortaleceu o estudo do território camponês ao explicitar que este é moldado pela dinâmica dos conflitos.

Foram abordadas, no segundo capítulo, as formas de tratar os moradores de rua: a legislação que criminaliza o ato mendicante, as políticas filantrópicas, as internações etc. Sobre o perfil da população de rua em São Paulo, observa-se que a grande maioria é composta de homens entre 20 e 40 anos e que em treze anos triplicou o número total de pessoas nas ruas. Esse aumento tem proximidade com a variação da taxa de desemprego; porém, a questão do morador de rua vai além da relação direta com o mundo do trabalho. As alternativas que não visam inserir os moradores de rua no mercado de trabalho assalariado, mas colocá-los no circuito da economia solidária, são: as cooperativas de catadores de materiais recicláveis, o Movimento dos Trabalhadores Sem Teto (MTST) e o MST.

Quanto às pesquisas sobre assentamentos de reforma agrária, foi visto que elas podem ser classificadas em quatro temas. São eles: território e territorialização; conflitos sociais internos e externos ao assentamento; ethos camponês e condições para permanência como assentado; cooperativismo, gestão, organização e sociabilidade nos assentamentos. Os trabalhos abordam um ou mais temas. A presente tese dialoga com os quatro. A maioria dos trabalhos sobre assentamentos resultantes da luta do MST é da área de geografia, por isso, a centralidade do tema da territorialização. Da discussão sobre território camponês, pode-se colocar que ele é moldado pelos conflitos internos, como se estes dessem 
“conteúdo" àquele. Acrescenta-se que o território possibilita a formação de relações nãocapitalistas, mas não as garante sem maiores aprendizados.

Sobre os conflitos internos, há a contribuição da noção das "invalidações recíprocas" (Cf. D’INCAO e ROY, 1995) e a dos trabalhos que realizam a crítica aos preconceitos contra "camponês" expressos pela cúpula do MST e que mostram a existência de uma diversidade de formas de organização política e econômica no interior dos assentamentos, que ultrapassam as antigas coletivizações "forçadas" pelo Movimento. Com a presente tese, acrescenta-se que o ethos camponês virou objeto de disputa no assentamento. Diferentes grupos ou indivíduos querem definir quem merece ou não ficar no assentamento. Portanto, transformar o ethos campesino numa essência é problemático porque supõe que só aqueles que a possuem permanecerão assentados.

Como a revisão dos trabalhos mostrou que os conflitos são comuns nos assentamentos, as contribuições da presente pesquisa são a de que a opção pelos lotes individuais é uma forma de gerir conflitos e que há um ritmo da conflituosidade nos assentamentos, pois, entre os dois e os cinco anos de formação de um assentamento ocorre uma intensidade maior de união e desunião: coletivos são desfeitos, cooperativas são abandonadas ou dão origem a associações e famílias sozinhas unem-se em associações. Quanto à gestão dos assentamentos, verificou-se na literatura que as associações têm papel central (Cf. CARVALHO, 1998), que as cooperativas variam entre mais e menos democráticas (Cf. CHRISTOFFOLI, 2000) e que elas representam ganhos políticos, mais do que econômicos (FABRINI, 2003).

Cabe colocar que o ponto central da questão da gestão dos conflitos no assentamento é a possibilidade de, juntamente com a consolidação de uma economia solidária, existir uma gestão pública, ou democrática, dos mesmos. Sobre a gestão democrática, as colocações de Quijano (2002), vistas anteriormente, são as mais pertinentes.

\section{Da empiria}

Aspectos gerais do assentamento e do início do trabalho de campo foram tratados no quarto capítulo. O enfoque esteve no movimento de união, desunião e reunião entre os assentados, que vai do momento em que a maioria deles vota pela moradia em lotes individuais, ao invés de agrovila, em 1999-2000, até a formação de grupos e associações a partir de 2002. A paisagem é moldada pelos conflitos: os lotes individuais, a formação de 
grupos etc. Pela interlocução com os assentados, observou-se a dinâmica de alianças e de ataques no assentamento. Com isso também foi possível construir uma relação de confiança entre pesquisador e pesquisado, a ponto de aquele aparecer como um elo na rede de uma parcela dos assentados.

A partir de 2001, houve no assentamento uma desunião entre os moradores, em que muitos deles passaram a se isolar devido aos conflitos. No entanto, de 2002 para 2003, surgiram duas associações e grupos de trabalhos com estufas. Entre as associações, houve a primeira tentativa dos "Exculhidos", que durou quatro meses e onde se encontram alguns ex-moradores de rua. Depois, com algumas variações reúnem-se para a formação da Compartilha, em duas tentativas, até a formalização em 2003. Porém, em 2004, essa associação sofreu um enfraquecimento. Essa associação formou-se em contraposição aos antigos coordenadores do pré-assentamento, que ergueram outra associação e grupos das estufas. Walter, um dos principais articuladores dos "Exculhidos" e da Compartilha, tem como objetivos a luta em conjunto e fazer alianças; tece muitos ataques aos seus inimigos políticos.

Há a associação Agro União, que iniciou em 2003 e se oficializou em 2004. Começou com 12 famílias e, em 2004, entraram mais duas. Os grupos das estufas são compostos por três semi-coletivos que se formaram a partir de 2002. Essa segunda associação e os grupos das estufas são os moradores que estão em melhores condições materiais no assentamento e unem-se compondo um grupo majoritário. Os membros da Agro União e dos grupos da estufas destacam-se como pessoas que convocam assembléias para tentativas de gestão do assentamento. Em 2004, acirrou-se a separação entre essa maioria e alguns membros da associação Compartilha. Vale observar que não há exmoradores de rua nesse grupo majoritário, alguns deles participaram da formação da Compartilha. A formação desses grupos mostrou que há brechas no mecanismo de “invalidações recíprocas” (Cf. D’INCAO e ROY, 1995) existente no assentamento.

As trajetórias daqueles que vieram das ruas mostram traços característicos da massa dos trabalhadores braçais do país. Vieram de famílias da zona rural, trabalharam nas cidades como pedreiro, pintor, porteiro, vigia etc. São marcados pelas migrações, pela procura de terra, de trabalho ou, às vezes, pelo perambular. Há um potencial de justiça social no assentamento na medida em que os conhecimentos não profissionalizados portados por esses trabalhadores podem ser legitimados, como foi discutido por Illich (1979). 
Para tratar o tema de ex-moradores de rua como camponeses, foi preciso lidar com a questão do ethos campesino. Foi feito um levantamento das categorias de acusação entre os assentados e verificou-se a construção do ethos. Eles acusam-se mutuamente de ser

"vagabundo", de "não ser digno" de estar assentado e de ser "mentiroso". Conclui-se que a busca de determinantes de campesinidade, sejam econômicos e/ou culturais, como aparece em trabalhos sobre assentamentos, são armadilhas, porque reproduzem brigas e divisões internas. $\mathrm{O}$ que não nega que no assentamento há a oportunidade para se (re)construir o ethos campesino e as relações não-capitalistas. Pode-se dizer que quem entrou para a luta pela terra é camponês e que o ethos é algo a ser formado na prática e não algo a ser tomado como uma essência que uns têm e outros não. Então, a possibilidade de se adaptar à vida na terra estaria mais ligada a estar numa rede do que a aptidão para ser agricultor.

Nas figuras 9 e 10, mostram-se como as redes surgem, configuram e atravessam o território. Como ensina Raffestin (1993), o território é o campo de ação dos poderes, por isso, esta tese enfoca os conflitos como disputas políticas que articulam tessitura, nós e redes.

No capítulo seis, tratou-se de três formas de lidar com o conflito: arbitragem estatal; gestão pública à reboque do conflito e à espera do Estado; gestão pública legitimada pelo Estado. Uma discussão decorrente dessas questões foi como o assentamento pode se construir como um local de emancipação e de democracia, segunda as posições de Santos (2002), Quijano (2002) e Singer (2002a).

\section{Das respostas}

Quanto à primeira hipótese levantada, foi possível constatar que o MST é uma alternativa aos moradores de rua; porém, é preciso que essa união do Movimento com a população de rua possibilite a formação de redes para que esta não caia no isolamento. Quando estão nas ruas, os "sem teto" conseguem estar inseridos em redes, geralmente conectadas ao trabalho da pastoral católica. No assentamento, esse contato não perdura ou muda de caráter (voltando-se mais para financiamentos e menos para a articulação política). Com as pessoas morando e produzindo em seus próprios lotes, os ex-moradores de rua e os homens sozinhos, em geral, carecem de mão-de-obra familiar e a falta de família é, muitas vezes, vista como uma oposição ao caráter camponês. Os apoios da direção do MST, da Igreja e de outros militantes podem servir para que essas pessoas 
cheguem ao assentamento com o potencial de formar um grupo voltado para formas de economia solidária, de acordo com a concepção de Singer (2002b).

A disputa pela campesinidade no assentamento manifesta-se na polarização entre as famílias versus homens sozinhos. Se a base da campesinidade está no valor moral da família, o homem sozinho estaria destituído dela. Desde o início do assentamento, houve uma tensão entre lideranças que não queriam homens sozinhos assentados e outras que defendiam o direito de todos permanecerem, pois a conquista da terra foi em conjunto. Constata-se que uma noção de campesinidade presente entre uma parcela dos assentados discrimina os homens sozinhos, porque não seriam capazes de trabalhar todo o lote. A negação do ethos não recai diretamente sobre o ex-morador de rua, mas sobre aqueles que vivem só. Vale observar que nem todos os homens sozinhos vieram das ruas e há exmoradores de rua com família.

Aqueles que vieram da rua não pertencem aos maiores grupos do assentamento estudado. Morar num lote proporciona-lhes teto, comida, trabalho, possibilidade de (re)constituir família; mas, há uma situação de relativa pobreza material e de sociabilidade. Aqueles que formaram família ou lutam para estar em grupo conseguem se manter mais facilmente do que aqueles que se isolaram. Um ex-morador de rua que não se manteve unido à associação Compartilha, acabou deixando o assentamento em 2004. Antes do início do trabalho de campo, houve dois casos de ex-moradores de rua que viviam sozinhos e desistiram de permanecer no assentamento. Poderia ser diferente se eles fossem para a luta pela terra com uma maior correlação de forças em relação às demais famílias, se formassem um bloco mais coeso e/ou se tivessem representantes ou apoiadores que auxiliassem na organização deles como um grupo. De certo modo, os ex-moradores de rua e os homens sozinhos são vistos no assentamento como pessoas pouco afeitas ao trabalho. As redes, para todos os assentados e - principalmente - para os ex-moradores de rua, são formas de ultrapassar o isolamento dos lotes e estar em comunicação com o mundo exterior ao assentamento para garantir algo a mais do que aquilo que é produzido no sítio. Retomando, o assentamento propiciou conquistas aos ex-moradores de rua: ter um pedaço de terra para morar, plantar e garantir parte da alimentação, formar ou reencontrar família, estar atado a redes e manifestar habilidades paralelas ao cultivo da terra. Porém, ainda não se consolidou entre eles uma alternativa socialista ao modo de produção capitalista.

Vejamos os elementos que se aproximam, ou não, da conceituação de economia solidária. A associação Compartilha, desde o grupo inicial dos "Exculhidos", tem como intenção de desenvolver projetos agropecuários em comum em alguns lotes, em paralelo ao 
roçado para a família; não possui trabalho assalariado; há reuniões para decidir sobre os projetos agrícolas em comum (cada sócio um voto); a organização é voltada para a produção e comercialização, e, há registro civil como associação (sem fins lucrativos). No último ano (2004), a associação perdeu sócios, eles não realizam projetos em conjunto e não há sobras a serem distribuídas. Pode-se dizer que a economia solidária, definida pela autogestão da produção coletiva e pelas decisões democráticas - conforme visto na Introdução -, está em estágio embrionário.

Em termos comparativos, há os casos da associação Agro União e dos grupos das estufas. Os objetivos da Agro União são o incentivo à produção de leite e de produtos agrícolas, a comercialização e a compra de implementos e máquinas em comum. Os sócios realizam reuniões regulares sobre o andamento do grupo, o que produzir em comum e a comercialização (cada sócio um voto). Há um registro civil como associação (sem fins lucrativos). Os grupos das estufas têm como objetivos a compra de sementes e de insumos e a comercialização em comum. Realizam reuniões sobre as compras, as vendas e as épocas de plantio (para colher no mesmo período e ganhar volume no venda). Cada grupo divide entre seus membros o montante da venda, geralmente, de forma igualitária ou conforme as horas trabalhadas. O trabalho nas estufas é coletivo, no sentido em que todos os membros laboram conforme uma escala e na época de maior atividade, como na colheita, todos se unem. O grupo todo investe na construção de novas estufas. Não possuem registro civil. Tanto a Agro Sul quanto os grupos das estufas mostraram crescimento e melhorias nas condições materiais de seus membros.

Dada essa discussão, foi possível problematizar um tema central na geografia da luta pela terra que é a questão do território camponês. Este território possibilita que não haja relações de produção capitalista, mas não garante que se construa uma economia solidária no assentamento. Por definição, o modo de vida e de produção camponês baseado na mão-de-obra familiar não é capitalista. Porém, só o fato de haver terra para frutificar essa forma de produção, não quer dizer que ela se tornará uma economia solidária (socialista). É preciso que o assentamento esteja inserido na rede da economia solidária e que os grupos se voltem para a gestão democrática (ou auto-gestão) da produção e dos conflitos sociais e para o reconhecimento do socialismo como algo vivido, desde já, nos interstícios do modo de produção capitalista. Pode-se dizer que, potencialmente, os grupos e associações mais fortes podem atrair aqueles que estão num grupo mais fraco, desde que não se consolide uma polarização entre os grupos. O trabalho de campo revela que a 
mobilidade de união e desunião entre os assentados é maior do que a tendência à polarização entre grupos.

O paradigma da reprodução do campesinato pela expansão do modo de produção capitalista permite que camponês seja um personagem moderno. Portanto, o camponês reivindica a tradição da família e do território e também a modernidade, no sentido da crítica e da possibilidade de superação daquele modo de produção. Ou seja, encontra-se no campesinato um repertório de ethos familiar e de luta por justiça social e por um modo de vida e de produção não-capitalista (quiçá socialista).

Quanto à segunda hipótese da tese, a principal constatação é que as associações e os grupos tendem a ser os mediadores da gestão pública dos conflitos internos no assentamento. No entanto, a gestão dos conflitos vive uma tensão entre depender do Estado e buscar autonomia, o que demonstra uma dificuldade de consolidação dessa gestão pública como algo que é de responsabilidade de toda a comunidade. O presidente da associação Agro União, por exemplo, é um dos organizadores das reuniões no assentamento, desde 2003.

Foram encontradas três formas de gerir os conflitos. Uma delas é a busca da arbitragem estatal (uma ação civil contra os ex-coordenadores do assentamento decorrente de uma partilha de dinheiro), outra é a gestão pública restrita ao conflito específico (tentativa de "venda" de lote) e a gestão pública que trabalha com o apoio do Estado ("venda" e abandono de lote e formação de uma comissão interna para apurar irregularidades), conforme visto no capítulo seis. Vale ressaltar que é relativamente comum nos conflitos pessoais entre vizinhos (briga por causa de gado que derruba cerca, por exemplo) o recurso a formas judiciais de gestão. Porém, houve somente um caso de ação judicial envolvendo o assentamento como um todo. Num momento em que não havia associações registradas (2002) e havia poucas reuniões e assembléias a forma judicial apareceu como gestão de um conflito relativo ao coletivo.

A demanda por justiça estatal é relativamente recente na história do campesinato brasileiro, surgindo com as atividades das Ligas Camponesas. Encontrou-se no assentamento a demanda por essa forma de justiça. No entanto, pela teoria de Black (1998) sobre o conflito social, sabe-se que a aplicação da lei é uma forma entre outras de exercer controle social. Além disso, como a lei comporta-se no espaço social realizando 
discriminações ${ }^{1}$, quando pessoas de baixo status social recorrem a ela, pouca ou nenhuma lei será aplicada. Então, a lei pode ser uma reivindicação legítima de alguns camponeses, mas ela não possibilita a realização daquilo que o autor denomina de justiça sociológica, que consiste na retirada de leis para mudar a configuração de um dado espaço social (BLACK, 1989). Segundo o autor, o controle social apresenta uma gama variável, conforme os contextos locais, sócio-culturais, históricos e que inclui e ultrapassa o controle estatal, ou seja, a lei. Isto é, pode variar de acordo com diferentes estilos, do mais formal e legal ao mais informal e casual. Então, para se mudar uma configuração sócio-espacial deve-se mudar ou diminuir determinado tipo de controle social. A contribuição do trabalho de Black está em mostrar que não há alteração no espaço social apenas com a maior aplicação do controle social do estilo penal.

Nos dois outros casos de conflito em que houve gestão pública, verificou-se que a presença de instâncias democráticas, como assembléias, em que cada um tem direito a voz e voto. No segundo caso tratado, as partes chegaram a um acordo quanto à irregularidade da venda do lote. No terceiro caso, o acordo ocorreu com a mediação dos agentes do INCRA.

O assentamento é uma fração de território camponês plasmado pelo conflito. As alianças, as controvérsias e os ataques são redes que configuram aquele local. As redes são formadas internamente, em alguns momentos cristalizam-se em organizações e permitem a comunicação, a troca de informações e a obtenção de recursos externos. Na fração territorial que é o assentamento, os lotes são nós; assim, a movimentação de ataques e alianças entre os moradores formando grupos e associações é a rede que o atravessa e permite fluxo com o exterior: venda, compra, financiamento e informações.

Uma das principais conclusões deste estudo é de que há um incipiente aprendizado da gestão democrática dos conflitos. Consolidando-se um modo de produção solidário, os assentados poderiam desenvolver formas solidárias e democráticas de gerir os conflitos. Há certa tendência nesse sentido, pois os moradores, por exemplo, fazem reuniões públicas e criam comissões para cuidar dos problemas do assentamento. Assim, é possível virar uma prática regular e se criar um ambiente de aprendizado de que é no espaço público onde se resolvem os conflitos. Porém, é preciso que as comissões, por exemplo, não façam

\footnotetext{
${ }^{1}$ A relevância da análise sociológica de Black sobre a lei é mostrar que ela se comparta de maneira desigual e discriminatória, apesar do preceito de igualdade. Pois, a igualdade está no plano do "dever ser" e não do "ser".
} 
discriminações entre os assentados para que todos se sintam parte do processo e aprendam a ver as reuniões e assembléias como espaço de todos.

Para terminar, reproduzo um poema de Álvaro de Campos, um dos heterônimos do poeta português Fernando Pessoa [1888-1935] (1985: 118-20), que sintetiza o incômodo que a presença do morador de rua traz para a racionalidade moderna.

Cruzou por mim, veio ter comigo, numa rua da Baixa

Aquele homem mal vestido, pedinte por profissão que se lhe vê na cara,

Que simpatiza comigo e eu simpatizo com ele;

E reciprocamente, num gesto largo, transbordante, dei-lhe tudo quanto tinha

(Exceto, naturalmente, o que estava na algibeira onde trago mais dinheiro:

Não sou parvo nem romancista russo, aplicado,

E romantismo, sim, mas devagar...).

Sinto uma simpatia por essa gente toda,

Sobretudo quando não merece simpatia.

Sim, eu sou também vadio e pedinte,

E sou-o também por minha culpa.

Ser vadio e pedinte não é ser vadio e pedinte:

É estar ao lado da escala social,

É não ser adaptável às normas da vida,

Às normas reais ou sentimentais da vida -

Não ser Juiz do Supremo, empregado certo, prostituta,

Não ser pobre a valer, operário explorado,

Não ser doente de uma doença incurável,

Não ser sedento da justiça, ou capitão de cavalaria,

Não ser, enfim, aquelas pessoas sociais dos novelistas

Que se fartam de letras porque têm razão para chorar lágrimas,

E se revoltam contra a vida social porque têm razão para isso

Não: tudo menos ter razão!

supor.

Tudo menos importar-me com a humanidade!

Tudo menos ceder ao humanitarismo!

De que serve uma sensação se há uma razão exterior para ela?

Sim, ser vadio e pedinte, o que é corrente:

É ser isolado na alma, e isso é que é ser vadio,

É ter pedir aos dias que passem, e nos deixem, e isso é que é ser

pedinte.

Tudo é mais estúpido como um Dostoiewski ou um Gorki.

Tudo mais é ter fome ou não ter que vestir.

$\mathrm{E}$, mesmo que isso aconteça, isso acontece a tanta gente.

Quem nem vale a pena ter pena da gente a quem isso acontece.

Sou vadio e pedinte a valer, isto é, no sentido translato,

E estou-me rebolando numa grande caridade por mim.

Coitado do Álvaro de Campos!

Tão isolado na vida! Tão deprimido nas sensações!

Coitado dele, enfiado na poltrona de sua melancolia!

Coitado dele, que com lágrimas (autênticas) nos olhos,

Deu hoje, num gesto largo, liberal e moscovita,

Tudo que tinha, na algibeira em que tinha pouco, àquele 
Pobre que não era pobre, que tinha olhos tristes por profissão.

Coitado do Álvaro de Campos, com quem ninguém se importa! Coitado dele que tem tanta pena de si mesmo!

E, sim, coitado dele!

Mais coitado dele que de muitos que são vadios e vadiam,

Que são pedintes e pedem,

Porque a alma humana é um abismo.

Eu é que sei. Coitado dele!

Que bom poder-me revoltar num comício dentro da minha al-

ma!

Mas até nem parvo sou!

Nem tenho a defesa de poder ter opiniões sociais.

Não tenho, mesmo, defesa nenhuma: sou lúcido.

Não me queiram converter a convicção: sou lúcido.

Já disse: sou lúcido.

Nada de estéticas com coração: sou lúcido.

Merda! Sou lúcido. 


\section{Referências bibliográficas}

\section{Livros, teses e dissertações}

ABRAMOVAY, Ricardo (1992). Paradigmas do Capitalismo Agrário em Questão. São Paulo, Rio de Janeiro, Campinas: Hucitec/ANPOCS/Unicamp.

ADORNO, Sérgio (1990). A Gestão Filantrópica da Pobreza Urbana. In: São Paulo em Perspectiva. São Paulo: Seade, Ano 4, Vol. 8, pp. 8-17, abril/junho.

ALBINO, Ma. Rita C. S. et alli (2001). Assentamento Clarice Lispector. Projeto experimental de conclusão de habilitação em Relações Públicas. Irene/SP, Faculdades Integradas de Irene - F. K. B., Dez.

ALMEIDA, Cláudia V. M. (2001). Educação de rua: os meninos e o tempo. In: Estudos Avançados - Dossiê Educação. São Paulo: Instituto de Estudos Avançados/USP, Vol. 15, No. 42, pp. 217-234.

ALMEIDA, Rosemeire Ap. (2003). Identidade, Distinção e Territorialização: o processo de (re)criação camponesa no Mato Grosso do Sul. Pres. Prudente/SP, Tese de doutoramento em Geografia, FCT/Unesp.

ARENDT, Hanna (1987). A Condição Humana. Rio de Janeiro: Forense Universitária.

AUGÉ, Marc (1999). O Sentido dos Outros: atualidade da antropologia. Petrópolis/RJ: Vozes.

BARAK, Gregg (1992). Gimme Shelter - a social history of homelessness in contemporary América. Nova York/EUA: Praeger.

BARONE, Luís A. (1996). Revolta, Conquista e Solidariedade: a economia moral dos trabalhadores rurais em três tempos. Araraquara/SP, Dissertação de mestrado apresentada ao programa de Sociologia, FCL/Unesp.

BARROS, Joana S. (2004). Moradores de Rua - pobreza e trabalho: interrogações sobre a exceção e a experiência política brasileira. São Paulo, Dissertação de mestrado apresentada ao Depto. de Sociologia, FFLCH/USP.

BAUMAN, Zygmunt (2003). Resíduos modernos das nações. Folha de S. Paulo Mais!, 23 nov., p. 3.

BLACK, Donald (1989). Sociological Justice. Nova York: Editora da Universidade de Oxford.

BLACK, Donald (1998). The Social Structure of Right and Wrong. San Diego: Academic Press [versão revisada de original de 1993].

BLACK, Donald (2002). "A Geometria da Lei" - entrevista com Donald Black realizada por SINGER, H., JUSTO, M. G. e BUORO, A. B.. In: Revista dos Tribunais, Ano 10, pp. 261-276. [Versão integral publicada em: International Journal of the Sociology of Law, No. 2, Vol. 30, pp. 101-129, 2002.]

BOMBARDI, Larissa M. (2001). O Bairro Reforma Agrária e o Processo de Territorialização Camponesa. São Paulo, Dissertação de mestrado apresentada ao 
Depto. de Geografia, FFLCH/USP. [Publicada em 2004 com o mesmo título pela editora Annablume, São Paulo.]

BOMBARDI, Larissa M. (2003). Geografia Agrária e responsabilidade social da ciência. In: Terra Livre. Campos e Cidade: multiplicidade teórica e metodológica. Ano 19, No. 21. São Paulo: AGB, pp. 41-53.

BONVICINO, Régis (2004). O Lixo. Folha de S. Paulo Mais!. 23 maio, p. 20.

BUORO, Andréa B. (1998). Negociando a Dignidade Humana: os familiares de presos e a percepção de direitos humanos. São Paulo, Dissertação de mestrado apresentada ao Depto. de Antropologia, FFLCH/USP.

BRANDÃO, Carlos R. (Org.) (1999a). Pesquisa Participante. São Paulo: Brasiliense.

BRANDÃO, Carlos R. (Org.) (1999b). Repensando a Pesquisa Participante. São Paulo: Brasiliense.

BRESCIANI, Maria Stela M. (1986). Lógica e Dissonância, Sociedade de Trabalho: Lei, Ciência, Disciplina e Resistência Operária. In: Revista Brasileira de História. São Paulo, No. 6, Vol. 11, pp. 7-44.

BRUNI, José C. (1989). Poder e Ordem Social na Obra de Augusto Comte. São Paulo, Tese de doutorado apresentada ao Depto. de Filosofia, FFLCH/USP.

CALDEIRA, Teresa (1988). A presença do autor e a pós-modernidade da antropologia. In: Novos Estudos Cebrap. São Paulo: Cebrap, No. 21, jul., pp. 133-157.

CAMPOS, Nazareno J. (2000). Terras de Uso Comum no Brasil - um estudo de suas diferentes formas. São Paulo, Tese de doutoramento apresentada ao Depto. de Geografia, FFLCH/USP.

CANDIDO, Antonio (1998 [1964].). Os Parceiros do Rio Bonito. Rio de Janeiro: Duas Cidades.

CAPEL SAEZ, Horácio (1999 [1977]). Fatores sociais e o desenvolvimento da ciência: o papel das comunidades científicas. In: Villalobos, Jorge U. G. (Org.). Horárcio Capel Saez - O Nascimento da Ciência Moderna e a América. Maringá/PR: Eduem, pp. 1-43.

CARVALHO, Horácio M. (1998). Formas de Associativismo Vivenciadas pelos Trabalhadores Rurais em Áreas Oficiais de Reforma Agrária no Brasil. In: www.nead.org.br, acessado em dez/2004.

CARVALHO, Horácio M. (1999). Interação Social e as Possibilidades de Coesão e de Identidade Sociais no Cotidiano da Vida Social dos Trabalhadores Rurais nas Áreas Oficiais de Reforma Agrária no Brasil. In: www.nead.org.br, acessado em $\operatorname{dez} / 2004$.

CARVALHO, Horácio M. (2002). “A emancipação do movimento no movimento de emancipação social continuada" (resposta a Zander Navarro). In: SANTOS, Boaventura S. [Org.]. Produzir para Viver: os caminhos da produção não capitalista. Rio de Janeiro: Civilização Brasileira, pp. 233-260.

CASTEL, Robert (1978). A Ordem Psiquiátrica: A idade de ouro do alienismo. Rio de Janeiro: Graal. 
CASTEL, Robert (2005). A Insegurança Social: o que é ser protegido? Petrópolis/RJ: Vozes.

CASTORIADIS, Conelius (1983). Autogestão e hierarquia [1974]. In: Socialismo ou Barbárie - o conteúdo do socialismo. São Paulo: Brasiliense.

CASTRO OLIVEIRA, Bernadete A. C. (1991). Os Posseiros de Mirassolzinho. São Paulo, Dissertação de mestrado apresentada ao Depto. de Antropologia, FFLCH/USP.

CASTRO OLIVEIRA, Bernadete A. C. (1998). Tempo de Travessia, Tempo de Recriação: Professia e Trajetória Camponesa. São Paulo, Tese de doutoramento apresentada ao Depto. de Antropologia, FFLCH/USP.

CHAYANOV, Alexander V. (1974 [1925]). La Organización de la Unidad Económica Campesina. Buenos Aires: Nova Visão.

CHRISTIE, Nils (1999). Elementos para uma geografia penal. In: Revista de Sociologia e Política. Curitiba: Universidade Federal do Paraná, pp. 51-57.

CHRISTOFFOLI, Pedro I. (2000). O Desenvolvimento de Cooperativas de Produção Coletiva de Trabalhadores Rurais no Capitalismo: Limites e Possibilidades. Curitiba, Dissertação de mestrado apresentada ao Centro de Pesquisa e Pósgraduação em Administração, Setor de Ciências Sociais Aplicadas, UFPR.

CLIFFORD, James (1986). "On Ethnographic Allegory", in: CLIFFORD, James e MARCUS, George M. (Org.). Writing Culture - The Poetics and Politics of Ethnography. Berkeley: UCP.

CLIFFORD, James e MARCUS, George M. (Org.) (1986). Writing Culture - The Poetics and Politics of Ethnography. Berkeley: UCP.

CLIFFORD, James (1998). A Experiência Etnográfica. Rio de Janeiro: Ed. UFRJ.

COMTE, Auguste (1983 [1852]). Catecismo Positivista, in: Comte. Col. Os Pensadores. São Paulo: Abril Cultural, $2^{\mathrm{a}}$. ed.

CONCEIÇÃO, Márcio M. (2003). Os Empresários do Lixo: um paradoxo da modernidade. Campinas: Editora Átomo.

CONCRAB (Confederação das Cooperativas de Reforma Agrária do Br. Ltda.) (1998). A Emancipação nos Assentamentos - os direitos e os cuidados que os assentados devem ter. Caderno de Cooperação Agrícola No. 6. São Paulo: Concrab.

COSTA, Alderon P. (1989). Este povo também quer viver. In: Travessia II. São Paulo, No. 4, pp. 37-40, maio-agosto.

CRAPANZANO, Vincent (1991). Diálogo. In: Anuário Antropológico/88. Brasília: Ed. UnB, pp. 59-80.

DaMATTA, Roberto (1992). "Relativizando o interpretativismo", in: CORRÊA, Mariza e LARAIA, Roque (Orgs.). Roberto Cardoso de Oliveira: homenagem. Campinas/SP: UNICAMP/IFCH, pp. 49-77.

DEAR, Michael e GLEESON, Brendan (1991). Community Attitudes Toward the Homeless. In: Urban Geography. Número especial sobre homelessness. No. 2, Vol. 12, pp. 155-176. 
DIAS, Leila C. (1995). "Redes: emergência e organização", in: CASTRO, Iná E. et alli (Org.). Geografia: Conceitos e Temas. Rio de Janeiro: Bertrand Brasil, pp. 141-62.

D'INCAO, Maria da Conceição \& ROY, Gerard (1995). Nós Cidadãos: aprendendo e ensinando a democracia. Rio de Janeiro: Paz e Terra.

DOWBOR, Ladislau (2000). O Mosaico Partido - a economia além das equações. Petrópolis/RJ: Vozes.

DUARTE, Élio Garcia (1998). Do Mutirão à Ocupação de Terras: manifestações camponesas contemporâneas em Goiás. São Paulo, Tese de doutorado apresentada ao Depto. de História, FFLCH/USP.

DURKHEIM, Émile (1985 [1912]). As Formas Elementares da Vida Religiosa, in: Durkheim, Col. Os Pensadores. São Paulo: Abril Cultural, pp. 203-45.

ERIBON, Didier (1990). Michel Foucault. São Paulo: Cia. das Letras.

FABRINI, João E. (2003). A Resistência Camponesa nos Assentamentos de Sem-Terra. Cascavel/PR: Edunioeste.

FAO/PNUD - MARA (Min. da Agricultura e da Reforma Agrária). Principais Indicadores Sócio-Econômicos dos Assentamentos de Reforma Agrária. Brasília: FAO/PNUD - MARA.

FELICIANO, Carlos A. (2003). O Movimento Camponês Rebelde e a Geografia da Reforma Agrária. São Paulo, Dissertação de mestrado apresentada ao Depto. de Geografia, FFLCH/USP.

FERNANDES, Bernardo M. (1999 [1996]). MST - Formação e territorialização. São Paulo: Hucitec, $2^{\mathrm{a}}$. ed.

FERNANDES, Bernardo M. (1999). Contribuição ao Estudo do Campesinato Brasileiro - Formação e Territorialização do Movimento dos Trabalhadores Rurais Sem Terra - MST, 1979-1999. São Paulo, Tese de doutorado apresentada ao Depto. de Geografia, FFLCH/USP.

FERREIRA, Brancolina (1994). "Estratégias de intervenção do Estado em áreas de assentamento: as políticas de assentamento do governo federal", in: MEDEIROS, Leonilde S. et alli (Orgs.) Assentamentos Rurais: uma visão multidisciplinar. São Paulo, Ed. Unesp, pp. 29-47.

FERREIRA, Elenar (2000). "A Cooperação no MST: da luta pela terra à gestão coletiva dos meios de produção", in: SINGER, Paul e SOUZA, André R. (Org.). A Economia Solidária no Brasil: a autogestão como resposta ao desemprego. São Paulo: Contexto.

FERRAZ, Flávio R. C. (1998). Andarilhos da Imaginação: um estudo sobre loucos de rua. São Paulo, Tese de doutorado em Psicologia Social apresentado ao Instituto de Psicologia, IP/USP.

FEYERABEND, Paul (1993). Prefácio, in: Against Method. Londres: Verso.

FOUCAULT, Michel (1983). "The Subject and Power", in: DREYFUS, Hubert L. e RABINOW, Paul. Michel Foucault - Beyond Structuralism and Hermeneutics. Chicago: UCP, 2a . ed., pp. 208-226. 
FOUCAULT, Michel (1988). História da Sexualidade I: a vontade de saber. Rio de Janeiro: Graal, $10^{\mathrm{a}}$. ed.

FOUCAULT, Michel (1993a). Microfísica do Poder. Rio de Janeiro: Graal, 11ª . ed.

FOUCAULT, Michel (1993b). Vigiar e Punir. Petrópolis/RJ: Vozes.

FRANCO, Maria Sylvia de Carvalho (1983 [1969]). Homens Livres na Ordem Escravocrata. São Paulo: Kairós, 3a. ed.

FREIRE, Paulo (1992). Pedagogia da Esperança: um reencontro como a Pedagogia do Oprimido. Rio de Janeiro: Paz e Terra.

FREIRE, Paulo (2001). Pedagogia da Autonomia: saberes necessários à prática educativa. Rio de Janeiro: Paz e Terra, $18^{\mathrm{a}}$. ed.

GARCIA Jr., Afrânio Raul (1990). O Sul: caminho do roçado. Estratégias de reprodução camponesa e transformação social. São Paulo/Brasília: Marco Zero/UNB/CNPq.

GEERTZ, Clifford (1989 [1973]). A Interpretação das Culturas. Rio de Janeiro: LTC.

GEERTZ, Clifford (1983). Local Knowledge. E.U.A.: BasicBooks.

GONÇALVES, Sérgio (2004). O MST em Querência do Norte - PR: da luta pela terra à luta na terra. Maringá/PR, Dissertação de mestrado apresentada ao programa de Geografia, UEM.

GRAZIANO, Xico (2003). A Farsa dos Sem-terra. O Estado de S. Paulo. São Paulo, 28/10/2003, p. 2.

GRUPO KRISIS (1999). Manifesto contra o trabalho. In: Cadernos do Labur, $\mathrm{n}^{\circ} 2$ (Laboratório de Geografia Urbana/Departamento de Geografia/Universidade de São Paulo). Tradução de Heinz Dieter Heidemann com colaboração de Cláudio Roberto Duarte.

HAESBERT da COSTA, Rogério (1995a). "Gaúchos" no Nordeste: Modernidade, DesTerritorialização e Identidade. São Paulo, Tese de doutorado apresentada ao Depto de Geografia, FFLCH/USP.

HAESBERT da COSTA, Rogério (1995b). "Desterritorialização: entre as redes e os aglomerados", in: CASTRO, Iná E. et alli (Org.). Geografia: Conceitos e Temas. Rio de Janeiro: Bertrand Brasil, pp. 165-205.

HARVEY, David (1996). Justice, Nature, and the Geography of Difference. Oxford: Blackwell.

HOCH, Charles (1991). The Spacial Organization of the Urban Homeless: a case study of Chicago. In: Urban Geography. Número especial sobre homelessness. No. 2, Vol. 12, pp. 137-154

IHA, Mônica H. (2001). Formação do acampamento Nova Canudos - Um estudo sobre a espacialização da luta pela terra no Brasil. São Paulo, Trabalho de Graduação Individual apresentado ao Depto. de Geografia, FFLCH/USP.

ILLICH, Ivan (1979). O Direito ao Desemprego Criador. Rio de Janeiro: Editorial Alhambra. 
JUSTO, Marcelo Gomes (1997). Tão comum e tão estranho: os moradores de rua e as fronteiras de nossa sociedade. In: Revista Caramelo. São Paulo, Faculdade de Arquitetura e Urbanismo (FAU)/ USP, No. 9, pp. 66-75, Dez.

JUSTO, Marcelo Gomes (2001). Entrevista com M. A. S. [morador de assentamento de reforma agrária e militante do MST]. In: www.ces.fe.uc.pt/emancipa/pt/voices/gen/miguelsantos.html. Projeto Vozes do Mundo, inserido na pesquisa Reinventando a Emancipação Social, sob orientação do sociólogo Boaventura de Sousa Santos, Centro de Estudos Sociais (CES), Coimbra - Portugal, 2 p. [Versão integral no prelo.]

JUSTO, Marcelo G. e SINGER, Helena (2001b). Sociology of Law in Brazil: a critical approach. In: The American Sociologist, Vol. 32, No. 2, p. 10-25.

JUSTO, Marcelo Gomes (2002). Capim na Fresta do Asfalto: conflito agrário violento e justiça. São Paulo: Humanitas/FAPESP.

KAUTSKY, Karl (1986). A Questão Agrária. Col. Os Economistas. São Paulo: Abril Cultural.

KUHN, Thomas (1996). The Structure of Scientific Revolutions. Chicago: UCP, $3^{\mathrm{a}}$. ed.

LACOSTE, Yves (2003 [1976]). A Geografia - Isso serve, em primeiro lugar, para fazer a guerra. Campinas/SP: Papirus, $7^{\mathrm{a}}$ ed.

LATOUR, Bruno (2000a). Ciência em Ação: como seguir cientistas e engenheiros sociedade afora. São Paulo: Editora UNESP.

LATOUR, Bruno (2000b). Jamais Fomos Modernos. São Paulo: Editora 34.

LEANDRO, José B. (1999). A autogestão no assentamento Fazenda Reunidas de Promissão, in: DAL RI, Neusa M. Economia Solidária - o desafio da democratização das relações de trabalho. São Paulo: Arte e Ciência, pp. 177-191.

LEFEBVRE, Henry (1986). "Problemas de Sociologia Rural" [1949]; "Perspectivas da Sociologia Rural” [1953], in: MARTINS, José de Souza (Org.) (1986a). Introdução Crítica à Sociologia Rural. São Paulo: Hucitec, 2a. ed., pp:144-177.

LEFEBVRE, Henry (1997 [1974]). The Production of the Space. Oxford-Inglaterra; Cambridge-E.U.A.: Blackwell Publishers. [Orig. (1974) La Production de l'Espace; trad.: Donald Nicholson-Smith.]

LOPES, João Marcos A. (2002). “'O Dorso da Cidade': os sem-terra e a concepção de uma outra cidade", in: SANTOS, Boaventura S. [Org.]. Produzir para Viver: os caminhos da produção não capitalista. Rio de Janeiro: Civilização Brasileira, pp. 283-326.

LOPES, José S. L. (1978). O Vapor do Diabo - o trabalho dos operários do açúcar. Rio de Janeiro: Paz e Terra, $2^{\mathrm{a}}$. ed.

MAIA, Doralice S. (1997). Os escritos etnográficos e a Geografia: encontros e desencontros. In: Geousp - Rev. da Pós-Graduação do DG/FFLCH/USP. São Paulo: Humanitas/FFLCH/USP, Número 2, pp. 21-9.

MARCOS, Valéria de (1996). Comunidade Sinsei - (U)Topia e Territorialidade. São Paulo, Dissertação de mestrado apresentada ao Depto. de Geografia, FFLCH/USP. 
MARCUS, George (1993). Entrevista para a revista Cadernos de Campo. In: Cadernos de Campo. São Paulo: Departamento de Antropologia, FFLCH/USP, No. 3, pp. 132-9.

MARQUES, Marta Inez M. (2000). De Sem-terra a "posseiro", a luta pela terra e a construção do território camponês no espaço da reforma agrária: o caso dos assentados nas fazendas Retiro e Velha - GO. São Paulo, Tese de doutorado apresentada ao Depto. de Geografia, FFLCH/USP.

MARTINS, José S. (2000). Reforma Agrária: o impossível diálogo. São Paulo: Edusp.

MARTINS, Ma. Fátima A. (2001). A Caminho da Rua: o encontro com as redes de assistência e a formação de laços sociais entre moradores de rua em Belo Horizonte. São Paulo, Tese de doutorado apresentada ao Depto. de Geografia, FFLCH/USP.

MARTINS, Sérgio Ricardo O. (1995). Migração no trecho - trabalho, assistência e degeneração: estudo da população que passa pelos albergues de Campo Grande MS. São Paulo, Dissertação de mestrado apresentada ao Depto. de Geografia, FFLCH/USP.

MARX, Karl (1978 [1852]). O 18 Brumário de Luís Bonaparte, in: Marx. Col. Os Pensadores. São Paulo: Abril Cultural, $2^{\mathrm{a}}$. ed.

MARX, Karl (1985). O Capital, Vol. I e II, Col. Os Economistas. São Paulo: Abril Cultural.

MARX, Karl (1961[1875]). Crítica ao Programa de Gotha, in: Marx \& Engels - Obras Escolhidas. Vol. 2. Rio de Janeiro: Vitória, pp. 205-236.

MATHEUS, Delwek (2003). Uma outra Concepção de Assentamento de Reforma Agrária: a Comuna da Terra. Trabalho de conclusão de curso de realidade brasileira a partir dos grandes pensadores bras. FSS/UFJF/MG - MST.

MERLEAU-PONTY, Maurice (1984). De Mauss a Lévi-Strauss (1960), in: MerleauPonty, Col. Os Pensadores. São Paulo: Abril Cultural, pp. 193-206, 2a . ed. [Org. Marilena Chauí.]

MINISTÉRIO DO TRABALHO - Sec. Nac. de Economia Solidária (Senaes) (2005). Programa Economia Solidária em Desenvolvimento - Plano de Ação 2005. (mineo.)

MIRANDA, Maria Elena (1998). Análise de uma situação de conflito entre os assentados e o MST. São Paulo, Dissertação de mestrado apresentada ao Depto. de Antropologia, FFLCH/USP.

MIRANDA, Maria Elena (2003). Os Assentados Frente aos Desafios Legais. Uma interpretação antropológica das relações jurídicas no assentamento de Promissão. São Paulo, Tese de doutoramento apresentada ao Depto. de Antropologia/FFLCH/USP.

MITIDIERO Jr., Marco Antônio (2002). O Movimento de Libertação dos Sem Terra (MLST) e as Contradições da Luta pela Terra no Brasil. São Paulo, Dissertação de mestrado apresentada ao Depto. de Geografia, FFLCH/USP.

MONBEIG, Pierre (1998). Pioneiros e Fazendeiros de São Paulo. São Paulo: Hucitec/Polis. 
MONTES, Maria Lúcia (1995). "População de Rua - sua Identidade e a Questão da Cidadania”, in: ROSA, C. M. M. (1995). População de Rua. Brasil e Canadá. São Paulo, Hucitec, pp. 191-199.

MORAES, Antônio C. R. (1981). Geografia: Pequena História Crítica. São Paulo: Hucitec.

MOURA, Margarida M. (1986). Camponeses. São Paulo: Ática.

MOURA, Margarida M. (1988). Os Deserdados da Terra - a lógica costumeira e judicial dos processos de expulsão e invasão da terra no sertão de Minas Gerais. Rio de Janeiro: Bertrand Brasil.

MST - Movimento dos Trabalhadores Rurais Sem Terra (1993). A Cooperação Agrícola nos Assentamentos. Caderno Formação No. 20. São Paulo: MST.

MST - Mov. dos Trab. Rurais Sem Terra - e CONCRAB - Conf. Nac. das Coop. da Ref. Agrária do $\mathrm{Br}$ - (1994). Questões Práticas sobre Cooperativas de Produção. Caderno Formação No. 21. São Paulo: MST/Concrab.

NASSER, Ana C. A. (1996). "Sair par o Mundo". Trabalho, Família e Lazer: relações e representação na vida dos excluídos. São Paulo, Tese de doutorado apresentada ao Depto. de Sociologia, FFLCH/USP.

NARITA, Stella (2000). Estudo dos processos pssicossociais que motivam um grupo de trabalhadores à participação no Movimento dos Trabalhadores Rurais Sem Terra no Pontal do Paranapanema - SP. São Paulo, Dissertação de mestrado apresentada ao Instituto de Psicologia, IP/USP.

NAVARRO, Zander (2002). “"Mobilização sem Emancipação' - as lutas sociais dos sem-terra no Brasil" e "O MST e a canonização da ação coletiva (resposta a Horácio Martins Carvalho)", in: SANTOS, Boaventura S. [Org.]. Produzir para Viver: os caminhos da produção não capitalista. Rio de Janeiro: Civilização Brasileira, pp. 189-232; 261-281.

NEVES, Delma P. (1983). Mendigo: o trabalhador que não deu certo. In: CiênciaHoje, Ano 1, No. 4, pp. 28-36, jan/fev.

NEVES, Delma P. (1995). "Comentários dos assessores sobre o perfil da população de rua”, in: ROSA, Cleisa M. M. (Org.) (1995). População de Rua. Brasil e Canadá. São Paulo: Hucitec, pp. 61-70.

NEVES, Delma P. (1995). A Agricultura Familiar: questões metodológicas. In: Reforma Agrária. Campinas/SP, Vol. 25, No. 2 e 3, pp. 21-36.

O’HALON, Rosalind e WASHBROOK, David (2000). "After Orientalism: Culture, Criticism and Politics in the Third World". In: CHATURVEDI, Vinayak (Org.) Mapping Subaltern Studies and the Postcolonial. Londres-Nova Iorque: Verso/New Left Review, pp. 191-219.

OLIVEIRA, A. D. \& VICENTE, C. M. (1989). Gente 'sem eira nem beira'. In: Travessia, II. São Paulo, No. 4, pp. 33-35, maio-agosto.

OLIVEIRA, Ariovaldo U. (1995). Modo Capitalista de Produção e Agricultura. São Paulo: Ática. 
OLIVEIRA, Ariovaldo U. (1997). A Fronteira Amazônica Mato-Grossense: grilagem, corrupção e violência. São Paulo, Tese de Livre Docência apresentada ao Depto. de Geografia, FFLCH/USP.

OLIVEIRA, Ariovaldo U. (2001). A longa marcha do campesinato brasileiro: movimentos sociais, conflitos e Reforma Agrária. In: Estudos Avançados - Dossiê Desenvolvimento Rural. São Paulo: Instituto de Estudos Avançados/USP, Vol. 15, No. 43, pp. 185-206.

OLIVEIRA, Ariovaldo U. (2002). "A geografia agrária e as transformações territoriais recentes no campo brasileiro", in: CARLOS, Ana F. (Org.). Novos Caminhos da Geografia. São Paulo: Contexto, pp. 63-110.

OLIVEIRA, Ariovaldo U. (2003). Barbárie e Modernidade: As transformações no campo e o agronegócio no Brasil. In: Terra Livre. Campos e Cidade: multiplicidade teórica e metodológica. São Paulo: AGB, Ano 19, No. 21, pp. 113 156.

OLIVEIRA, Francisco (1991). "Uma Alternativa Democrática ao Liberalismo", in: WEFFORT, Francisco et alli (1991). A Democracia como Proposta. Rio de Janeiro: Ibase.

OLIVEIRA, Francisco (2000). "Passagem na Neblina", in: OLIVEIRA, Francisco; STEDILE, João P.; GENOINO, José. Classes Sociais em Mudança e a Luta pelo Socialismo. Série: Socialismo em Discussão. São Paulo: Ed. Fund. Perseu Abramo.

OLIVEIRA, Luciano (1997). Os Excluídos “Existem”? Notas sobre a elaboração de um novo conceito. In: Revista Brasileira de Ciências Sociais. No. 33, ano 12, pp: 4961.

OLIVEIRA, Roberto Cardoso de (2000). O Trabalho do Antropólogo. Brasília/São Paulo: Paralelo 15, Ed. Unesp, $2^{\mathrm{a}}$. ed.

PEIRANO, Mariza (1992). “Os antropólogos e suas linhagens”, in: CORRÊA, Mariza e LARAIA, Roque (Orgs.). Roberto Cardoso de Oliveira: homenagem. Campinas/SP: UNICAMP/IFCH, pp. 31-47.

PEREIRA, José Roberto (2000). De Camponeses a Membros do MST: os novos produtores rurais e sua organização social. Brasília/DF, Tese de doutorado apresentada ao Depto. de Sociologia, ICS/UnB.

PEREIRA de QUEIROZ, Maria Isaura (1991). "Das técnicas", in: Variações sobre a técnica de gravador no registro de informação viva. São Paulo: T. A. Queiroz, pp: 56-67.

PERROT, Michele (1992). "As três eras da disciplina industrial na França do século XIX”, in: Os Excluídos da História. Rio de Janeiro: Paz e Terra, 2a . ed, pp. 53-80.

PESSOA, Fernando (1985). Poemas. Rio de Janeiro: Nova Fronteira.

PINHEIRO, Paulo Sérgio M. S. (1981). "Violência e Cultura", in: LAMOUNIER, B.(Org.) Direito, Cidadania e Participação. São Paulo: T. A. Quieroz, 1981.

QUIJANO, Aníbal (2002). "Sistemas alternativos de produção?", in: SANTOS, Boaventura S. [Org.]. Produzir para Viver: os caminhos da produção não capitalista. Rio de Janeiro: Civilização Brasileira, pp. 473-514. 
RAFFESTIN, Claude (1993 [1980]). Por uma Geografia do Poder. São Paulo: Ática.

RANCIÈRE, Jacques (1994). "O Dissenso", in: NOVAES, Adauto (Org.). A Crise da Razão. São Paulo: Minc-Funarte/Cia. das Letras, pp. 367-82.

RANDOLPH, Rainer (1999). Sociedade em Rede: Paraíso ou Pesadelo? Reflexões acerca de novas formas de articulação social e territorial das sociedades. In: GEOgraphia, Ano 1, No. 2, www.uff.br/geographia, pp. 27-53, acessado em $01 / 2005$.

RAPCHAN, Elaine S. (1993). De Identidades e Pessoas: um estudo sobre os Sem Terra de Sumaré. São Paulo, Dissertação de mestrado apresentado ao Depto. de Antropologia, FFLCH/USP.

RATZEL, Friedrich (1990). Ratzel, Col. Grandes Cientistas Sociais. São Paulo: Ática.

RECLUS, Élisée (1985). Élisée Reclus, Col. Grandes Cientistas Sociais. São Paulo: Ática.

RODRÍGUEZ, César (2002). “À Procura de Alternativas Econômicas em Tempos de Globalização: o caso das cooperativas de recicladores de lixo na Colômbia", in: SANTOS, Boaventura S. [Org.]. Produzir para Viver: os caminhos da produção não capitalista. Rio de Janeiro: Civilização Brasileira, pp. 329-367.

ROSA, Cleisa M. M. (Org.) (1995). População de Rua. Brasil e Canadá. São Paulo: Hucitec.

SACHS, Ignacy (2001). Brasil rural: da descoberta à invenção. In: Estudos Avançados Dossiê Desenvolvimento Rural. São Paulo: Instituto de Estudos Avançados/USP, Vol. 15, No. 43, pp. 75-82.

SADER, Maria Regina C. T. (1986). Espaço e Luta no Bico do Papagaio. São Paulo, Tese de doutorado apresentada ao Depto. de Geografia, FFLHCH/USP.

SANTOS, Boaventura S. (1997). Por uma concepção multicultural de direitos humanos. In: Revista Crítica de Ciências Sociais. Lisboa: Centro de Estudos Sociais, No. 48, pp. 11-32.

SANTOS, Boaventura S. (2000). Crítica da Razão Indolente: contra o desperdício da experiência. São Paulo: Cortez.

SANTOS, Boaventura S. [Org.] (2002). Produzir para Viver: os caminhos da produção não capitalista. Rio de Janeiro: Civilização Brasileira.

SCHIMDT, Maria Luisa S. (2003). Pesquisa qualitativa, alteridade e comunidades interpretativas. In: Imaginário. Diversidade Cultural. São Paulo: NIME/LABI/IP/USP, No. 9, pp. 57-64.

SCHMITT, Jean-Claude (1990). "A História dos Marginais", in: Le GOFF, J. A História Nova. São Paulo: Martins Fontes.

SCHNABEL, Paul (1992). Down and Out: Social Marginality and Homelessness. In: The International Journal of Social Psychiatry. No. 1, Vol 38, pp. 59-67.

SCHREINER, Davi F. (2002). Entre a Exclusão e a Utopia. Um estudo sobre os processos de organização da vida cotidiana nos assentamentos rurais (Região Sudoeste/Oeste do Paraná). São Paulo, Tese de doutorado apresentada ao Depto. de História, FFLCH/ USP. 
SHANIN, Teodor (1983). La Clase Incómoda: sociología política del campesinado en una sociedad en desarrollo (Rusia 1910-1925). Madrid: Alianza Editorial.

SIGAUD, Lygia (1979). Os Clandestinos e os Direitos: estudo sobre trabalhadores da cana-de-açúcar de Pernambuco. São Paulo: Duas Cidades.

SILVA, José Graziano (2001). Velhos e novos mitos do rural brasileiro. In: Estudos Avançados - Dossiê Desenvolvimento Rural. São Paulo: Instituto de Estudos Avançados/USP, Vol. 15, No. 43, pp. 37-50.

SIMONETTI, Mirian Claudia L. (1999). A Longa Caminhada - a (re)construção do território camponês em Promissão. São Paulo, Tese de doutorado apresentada ao Depto. de Geografia, FFLCH/USP.

SINGER, Paul (1998). Globalização e Desemprego - diagnóstico e alternativas. São Paulo: Contexto.

SINGER, Paul (2002a). "A recente ressurreição da economia solidária no Brasil", in: SANTOS, Boaventura S. [Org.]. Produzir para Viver: os caminhos da produção não capitalista. Rio de Janeiro: Civilização Brasileira, pp. 81-129.

SINGER, Paul (2002b). Introdução à Economia Solidária. São Paulo: Ed. Fund. Perseu Abramo.

SINGER, Paul (2004). Desenvolvimento Capitalista e Desenvolvimento Solidário. In: Revista Estudos Avançados. Vol. 18, No. 51. São Paulo: Instituto de Estudos Avançados/USP, pp. 7-22.

SIZANOSKI, Raquel (1998). O Novo dentro do Velho: Cooperativas de Produção Agropecuária do MST (Possibilidades e limites na construção de outro coletivo social). Florianópolis/SC, Dissertação de mestrado apresentada ao programa de Sociologia Política, CFCH/UFSC.

SMITH, David (1994). Geography and Social Justice. Oxford-Inglaterra; CambridgeE.U.A.: Blackwell.

SOJA, Edward W. (1993). Geografias Pós-modernas: a reafirmação do espaço na teoria social. Rio de Janeiro: Jorge Zahar Ed.

SOUZA, Marcelo J. L. (1995). "O Território: sobre espaço e poder, autonomia e desenvolvimento", in: CASTRO, Iná E. et alli (Org.). Geografia: Conceitos e Temas. Rio de Janeiro: Bertrand Brasil, pp. 77-116.

SOUZA, Maria A. (1999). As Formas Organizacionais de Produção em Assentamentos Rurais do Movimento dos Trabalhadores Rurais - MST. Campinas/SP, Tese de doutorado em Educação, FE/Unicamp.

SPOSATI, Aldaíza (1988). Vida Urbana e Gestão da Pobreza. São Paulo: Cortez.

SPOSATI, Aldaíza (2003). Mínimos de Civilidade, in: Folha de S. Paulo. São Paulo, 18/12/03, p. A-3.

SPOSITO, Eliseu S. (2001). A propósito dos paradigmas de orientações teóricometodológicas na Geografia contemporânea. In: Terra Livre. Paradigmas da Geografia Parte 1. São Paulo: AGB, No. 16, pp. 99-112. 
STAVENHAGEN, Rodolfo (1985). Etnodesenvolvimento: uma dimensão ignorada no pensamento desenvolvimentista. In: Anuário Antropológico/84. Rio de Janeiro: Tempo Brasileiro, pp. 11-44.

STEDILE, João Pedro (1994). “A Questão Agrária e o Socialismo”, in: STEDILE, João P. (Org.). A Questão Agrária Hoje. Porto Alegre: Ed. da Universidade/UFRGS, $2^{\mathrm{a}}$. ed., pp. 306-22.

STEDILE, João Pedro e FERNANDES, Bernardo M. (1999). Brava Gente - A trajetória do MST e a luta pela terra no Brasil. São Paulo: Ed. Fund. Perseu Abramo.

STOFFELS, Maire-Ghislaine (1977). Os Mendigos na Cidade de São Paulo. Rio de Janeiro: Paz e Terra.

THOMPSON, Edward P. (1979). "La Sociedad Inglesa del Siglo XVIII: Lucha de Clases sin Clases?", in: Tradioción, Revuelta y Consciencia de Clase. Barcelona, Editorial Crítica.

THOMPSON, Edward P. (1993). "The Moral Economy of the English Crowd in the Eighteenth Century"; "The Moral Economy Reviewed”, in: Customs in Common. Nova York, The New Press.

URUSHIMA, Andréa Yuri F. (2000). Projeto de Agrovila para Assentamento Clarice Lispector - MST. Trabalho Final de Graduação. São Paulo, Faculdade de Arquitetura, FAU-USP.

VELHO, Otávio G. (1979). Capitalismo Autoritário e Campesinato. São Paulo - Rio de Janeiro: Difel, $2^{\text {a }}$. ed.

VIEIRA, Ma. Antonieta C. et alli. (Org.) (1994). População de Rua, quem é, como vive, como é vista. São Paulo: Hucitec.

VIEIRA, Ma. Antonieta C. (1995). "São Paulo”, in: ROSA, Cleisa M. M. (Org.) (1995). População de Rua. Brasil e Canadá. São Paulo: Hucitec, pp. 42-5.

WEBER, Max (1967). "Burocracia”, in: GERTH, H. e MILLS, W. (Org.). Ensaios de Sociologia. Rio de Janeiro: Zahar, pp. 229-282.

WEINER, Sheldon e WEAVER, Lelon (1974). Begging and Social Deviance on Skid Row. In: Quartely Journal of Studies on Alcohol. No. 4, Vol. 35, 4, pp. 1307-1315.

WOLF, Eric (1979). "Las Rebeliones Campesinas", in: SHANIN, Theodor (Org.). Campesinos y Sociedades Campesinas. México: Fundo de Cultura Econômica. [Original de 1969]

WOORTMANN, Klass (1990). “Com Parente Não se Neguceia” O Campesinato Como Ordem Moral. In: Anuário Antropológico/87. Brasília/DF: Ed. UnB, pp. 11-73.

ZIMMERMANN, Neusa C. (1994). "Os desafios da organização interna de um assentamento rural", in: MEDEIROS, Leonilde S. et alli (Orgs.) Assentamentos Rurais: uma visão multidisciplinar. São Paulo, Ed. Unesp, pp. 205-24. 


\section{Mapas}

Instituto Brasileiro de Geografia e Estatística - IBGE (1971). Carta do município. Escala 1: 50.000

Instituto Geográfico e Cartográfico do Governo do Estado de São Paulo (1981). Carta de utilização da terra do estado de São Paulo. Escala 1: 750.000

\section{Jornais}

CORREIO BRASILIENSE. Brasília, 12/11/2000.

FOLHA DE SÃO PAULO. São Paulo, 04/09/94; 12/09/94; 13/12/1996; Cresce número de sem-teto em Nova York, 13/08/98, p. A-15; 20/05/2001, p. C-1; NY cria plano para tirar sem-teto da rua, 20/05/2001, p. A-10.

JORNAL DO CAMPUS. São Paulo, 10/10/1996, p. 7; 10/10/2000.

JORNAL NOSSA TERRA. Irene/SP, de 13 a 19/09/2003, p. A - 4; de 27/9 a 3/10/2003, p. A - 4 .

O TRECHEIRO. São Paulo, No. 36, Ano VI, Set/1996, p. 3; No. 16, Ano V, Jan.1995, p. 2; Especial "Sem Terra", Ano V, p.2; No. 56, Ano VII, Jul/1998, p. 3; No. 62, Ano IX, Fev/1999.

\section{Vídeos e filmes}

ALBINO, Ma. Rita C. S. et alli (2001). Assentamento Clarice Lispector. Irene/SP, Faculdades Integradas de Irene - F. K. B. VHS.

CHNAIDERMAN, Mirian (1994). Dizem que sou Louco. Duração: 12 min., 35 mm.

GEBRIM, Magda (1999). Biblioteca Viagem ao Céu. Duração: 17 min., VHS.

MOCARZEL, Evaldo S. V. (2003). À Margem da Imagem. Duração: 90 min., 35mm.

MORAES, Tetê (1987). Terras para Rose. Duração: 84 min., 35 mm.

MORAES, Tetê (2001). O Sonho de Rose - 10 anos depois. Duração: 92 min., 35 mm. 